
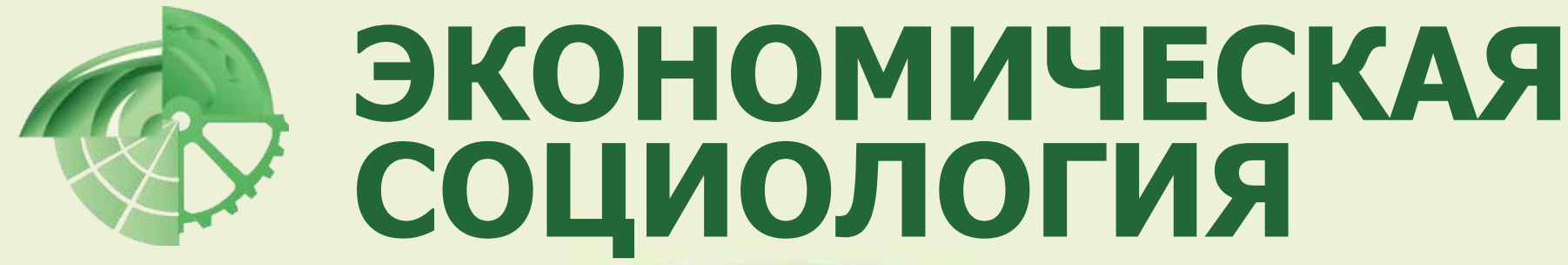

JOURNAL OF ECONOMIC SOCIOLOGY = EKONOMICHESKAYA SOTSIOLOGIYA

Читайте в номере:

Interview with Peter Schweitzer: "If You No Longer Allow for the Possibility of Alterity, You are Limiting Your Options of Analyzing the World(s)"

Семёнов А. В., Бедерсон В. Д. Организационные реакции российских НКО на законодательные изменения 2012 г.

Аткинсон Э. Б. Что такое «неравенство», и можем ли мы его преодолеть?

Попова П. А. Как объяснить финансовый конфликт в семье? Обзор экономических, психологических и социологических концепций 


\section{Экономическая}

социология

Т. 18. № 2

Март 2017

Электронный журнал www.ecsoc.msses.ru www.ecsoc.hse.ru

ISSN 1726-3247

\section{Адрес редакции}

101000, Россия,

г. Москва,

ул. Мясницкая,

д. 20, комн. 406

тел.: +7 (495) 628-48-86

email: ecsoc@hse.ru

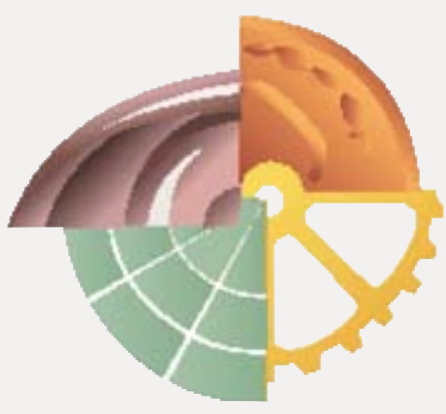

Journal of Economic Sociology

Vol. 18. No 2.

March 2017

Electronic journal

www.ecsoc.msses.ru

www.ecsoc.hse.ru

ISSN 1726-3247

\section{Contacts}

20 Myasnitskaya street, room 406

101000, Moscow,

Russian Federation

phone: +7 (495) 628-48-86

email: ecsoc@hse.ru лектронный журнал «Экономическая социология» издаётся с 2000 г. Учредителями являются Национальный исследовательский университет «Высшая школа экономики» (с 2007 г.) и Вадим Валерьевич Радаев (главный редактор).

Цель журнала - утверждать международные стандарты экономико-социологических исследований в России, представлять современные работы российских и зарубежных авторов в области экономической социологии, информировать профессиональное сообщество о новых актуальных публикациях и исследовательских проектах, а также вовлекать в профессиональное сообщество молодых коллег.

Журнал представляет собой специализированное академическое издание. В нём публикуются материалы, отражающие современное состояние экономической социологии и способствующие развитию данной области в её современном понимании. В числе приоритетных тем: теоретические направления экономической социологии, социологические исследования рынков и организаций, социально-экономические стратегии индивидов и домашних хозяйств, неформальная экономика. Также публикуются тексты из смежных дисциплин - неоинституциональной экономической теории, антропологии, экономической психологии и других областей, которые могут представлять интерес для экономсоциологов.

Журнал публикует пять номеров в год: в январе, марте, мае, сентябре и ноябре. Доступ ко всем номерам журнала постоянный, свободный и бесплатный по адресу: http:/ www.ecsoc.hse.ru. Каждый номер содержится в едином файле (10-12 п. л. в PDF).

Журнал входит в список ВАК России, индексируется в Российском индексе научного цитирования (РИНЦ), Emerging Sources Citation Index (ESCI) из Web of Science Core Collection и Scopus.

Требования к авторам изложены по адресу: http://ecsoc.hse.ru/author_requirements. html

В журнале применяется двойное анонимное рецензирование статей. Все материалы проходят через полный цикл редакторской обработки и корректуры.

Плата с авторов журнала не взимается. Ускоренные сроки публикации статей не предусмотрены.

Tournal of Economic Sociology was established in 2000 as one of the first academic e-journals in Russia. It is funded by the National Research University Higher School of Economics (HSE).

Journal of Economic Sociology promotes international standards of research in economic sociology, presenting new research carried out by Russian and international scholars, introducing new books and research projects, and attracting young scholars into the field.

Journal of Economic Sociology is a specialized academic journal representing the mainstreams of thinking and research in international and Russian economic sociology. Journal of Economic Sociology provides a framework for discussion of the following key issues: major theoretical paradigms in economic sociology, sociology of markets and organizations, social and economic strategies of households, informal economy. Journal of Economic Sociology also welcomes research papers written within neighboring disciplines - new institutional economics, anthropology, economic psychology and related fields, which can be of interest for economic sociologists.

Journal of Economic Sociology has a wide Russian speaking audience, living both in Russia and abroad. Its main target group comprises research scholars, university professors, policy-makers, post-graduates, undergraduates and others who are interested in economic sociology.

Journal of Economic Sociology is indexed by Emerging Sources Citation Index (ESCI) from Web of Science ${ }^{\mathrm{TM}}$ Core Collection and Scopus.

Journal of Economic Sociology is a bimonthly journal released in five issues (January, March, May, September, and November). Journal of Economic Sociology provides permanent free access to all issues in PDF. Journal of Economic Sociology applies blind peer-review procedures (two referees for each research paper). All papers are subject to editing, proofreading, and professional design layout.

Guidelines for authors: http://ecsoc.hse.ru/author_requirements.html 
Экономическая социология

Т. 18. № 2.

Март 2017

Электронный журнал www.ecsoc.msses.ru www.ecsoc.hse.ru

\section{ISSN 1726-3247}

Журнал выходит

пять раз в год

Учредители:

- Национальный исследовательский университет «Высшая школа экономики»

- В. В. Радаев

Издаётся с 2000 года

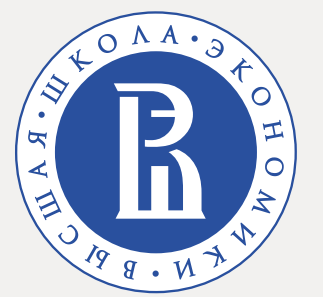

НАЦИОНАЛЬНЫЙ ИССЛЕДОВАТЕЛЬСКИЙ УНИВЕРСИТЕТ

\section{Редакция}

Главный редактор:

Редактор выпуска:

Вёрстка:

Корректор:

Ответственный

секретарь:

Сотрудники

редакции:
Радаев Вадим Валерьевич (НИУ ВШЭ, Россия)

Соколова Татьяна Виленовна (НИУ ВШЭ, Россия)

Мишина Мария Евгеньевна (Россия)

Андрианова Надежда Викторовна (НИУ ВШЭ, Россия)

Котельникова Зоя Владиславовна (НИУ ВШЭ, Россия)

Назарбаева Елена Алексеевна (НИУ ВШЭ, Россия)

Конрой Наталья Викторовна (НИУ ВШЭ, Россия)

\section{Международный редакционный совет}

Ашвин Сара

(Ashwin, Sarah)

Гербер Тед

(Gerber, Ted)

Гусева Аля (Guseva, Alya)

Зависка Джейн (Zavisca, Jane)

Линднер Петер

(Lindner, Peter)

Сводер Кристофер

(Swader, Christopher)

Якубович Валерий

(Yakubovich, Valery)
Лондонская школа экономики и политических наук

(Великобритания)

Висконсинский университет в Мэдисоне

(США)

Университет Бостона (США)

Университет Аризоны (США)

Университет Франкфурта-на-Майне

им. И. В. Гёте (Германия)

Лундский университет (Швеция)

Бизнес-школа ESSEC (Франция)

\section{Редакционный совет}

\section{Богомолова}

Татьяна Юрьевна

Веселов

Юрий Васильевич

Волков

Вадим Викторович

Гимпельсон

Владимир Ефимович

Лапин

Николай Иванович

Малева

Татьяна Михайловна

Овчарова

Лилия Николаевна

Радаев

Вадим Валерьевич

(главный редактор)

Хахулина

Людмила Александровна

Чепуренко Александр Юльевич

Шанин Теодор

\section{Шкаратан Овсей Ирмович}

Институт экономики и организации промышленного производства СО РАН (Россия)

Санкт-Петербургский государственный университет (Россия)

Европейский университет в Санкт-Петербурге (Россия)

НИУ ВШЭ (Россия)

Институт философии РАН (Россия)

Институт социального анализа и прогнозирования РАНХиГС (Россия)

НИУ ВШЭ (Россия)

НИУ ВШЭ (Россия)

Аналитический центр Юрия Левады (Россия)

НИУ ВШЭ (Россия)

Московская Высшая школа социальных и экономических наук (Россия) НИУ ВШЭ (Россия) 
Journal of Economic Sociology Vol. 18. No 2.

March 2017

Electronic journal www.ecsoc.msses.ru $\underline{\text { www.ecsoc.hse.ru }}$

\section{ISSN 1726-3247}

Journal of Economic Sociology is a bimonthly journal released in five issues in annual volume

\section{Establishers}

- National Research University Higher School of Economics

- Vadim Radaev

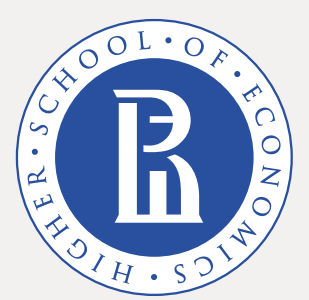

NATIONAL RESEARCH UNIVERSITY

\section{Editors}

Editor-in-Chief:

Editor:

Design and Layout:

Proofreader:

Managing Editor:

Editorial Staff:

Vadim Radaev (HSE, Russia)

Tatyana Sokolova (HSE, Russia)

Maria Mishina (Russia)

Nadezda Andrianova (HSE, Russia)

Zoya Kotelnikova (HSE, Russia)

Elena Nazarbaeva (HSE, Russia)

Natalia Conroy (HSE, Russia)

\section{International Editorial Council}

Sarah Ashwin

Ted Gerber

Alya Guseva

Peter Lindner

Christopher Swader

Valery Yakubovich

Jane Zavisca

\section{Editorial Council}

Tatyana Bogomolova

Alexander Chepurenko
Vladimir Gimpelson
Lyudmila Khakhulina
Nikolay Lapin

Tatyana Maleva

Lilia Ovcharova

Vadim Radaev (Editor-in-Chief)

Theodor Shanin

Ovsey Shkaratan

Yuriy Veselov

Vadim Volkov
The London School of Economics and Political Science (UK)

University of Wisconsin-Madison (USA)

Boston University (USA)

Goethe University Frankfurt (Germany)

Lund University (Sweden)

ESSEC Business School (France)

The University of Arizona (USA)
Institute of Economics and Industrial Engineering of the Siberian Branch of Russian Academy of Sciences (Russia)

HSE (Russia)

HSE (Russia)

Yuri Levada Analytical Center (Russia)

Institute of Philosophy of Russian Academy of Sciences (Russia)

Institute of Social Analysis and Forecasting, The Russian Presidential Academy

of National Economy and

Public Administration (Russia)

HSE (Russia)

HSE (Russia)

Moscow School of Social and Economic Sciences (Russia)

HSE (Russia)

Saint Petersburg State University (Russia)

European University at Saint Petersburg (Russia) 


\section{Содержание}

Вступительное слово главного редактора (В. В. Радаев)

7

\section{Тексты на русском языке}

\section{Новые тексты}

\section{А. В. Семёнов, В. Д. Бедерсон}

Организационные реакции российских НКО на законодательные изменения 2012 г.

\section{Расширение границ}

Э. Б. Аткинсон

Что такое «неравенство», и можем ли мы его преодолеть?....

\section{Дебютные работы}

А. А. Андреева, Ю. Д. Климешова, М. А. Кудрявиева, А. П. Лобанова

Рационализация жизни современного человека

на примере анализа потребления воды жителями Москвы 80

\section{Профессиональные обзоры}

\section{П. А. Попова}

Как объяснить финансовый конфликт в семье?

Обзор экономических, психологических и социологических концепций

\section{Новые книги}

\section{Н. В. Конрой}

Разумный альтруизм: можно ли примирить мораль и рынок?

Рецензия на книгу: Berend Z. 2016. The Online World of Surrogacy.

NY, Oxford: Berghahn Books. 270 p

\section{Конференции}

XVIII Международная научная конференция

по проблемам развития экономики и общества НИУ ВШЭ (Москва),

11-14 апреля 2017 г.

\section{Тексты на английском языке}

\section{Interviews}

Interview with Peter Schweitzer: "If You No Longer Allow

for the Possibility of Alterity, You are Limiting Your Options of Analyzing

the World(s)" (interviewed by Elena Gudova) 


\section{Contents}

Editor's Foreword (Vadim Radaev)

\section{Texts in Russian}

\section{New Texts}

Andrei Semenov, Vsevolod Bederson

Organizational Reactions of Russian NGOs to 2012 Legislative Changes

\section{Beyond Borders}

Anthony B. Atkinson

Inequality: What Can be Done? (an excerpt).

\section{Debut Studies}

Anastasia Andreeva, Julia Klimeshova, Maria Kudryavtseva, Anastasia Lobanova

Rationalization of Modern Life: The Case of Water Consumption in Moscow

\section{Professional Reviews}

Polina Popova

How to Explain Financial Disagreements in Families:

A Review of Economic, Psychological and Sociological Theories

\section{New Books}

Natalia Conroy

Rational Altruism: Is it Possible to Reconcile Morality with Markets?

Book Review: Berend Z. (2016) The Online World of Surrogacy,

NY, Oxford: Berghahn Books. 270 p.

\section{Conferences}

XVIII April International Academic Conference on Economic

and Social Development, National Research University Higher School of Economics,

Moscow, 11-14 April 2017.

\section{Texts in English}

\section{Beyond Borders}

Interview with Peter Schweitzer: "If You No Longer Allow for the Possibility of Alterity, You are Limiting Your Options of Analyzing the World(s)"

(interviewed by Elena Gudova) 


\section{VR ВСТУПИТЕЛЬНОЕ СЛОВО ГЛАВНОГО РЕДАКТОРА}

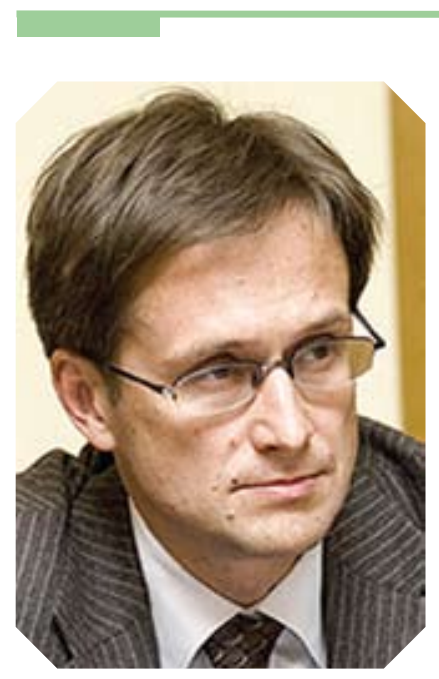

Уважаемые читатели!

С особым удовольствием сообщаем, что в этом году Высшая школа экономики впервые в истории вошла в список топ-100 предметного рейтинга лучших университетов мира — QS World University Rankings by Subject, 2017 - по социологии. Это большое достижение, и ВШЭ - единственный российский университет, который взял эту высоту. Всего же Высшая школа экономики вошла в предметные рейтинги QS по 13 дисциплинам, включая топ-100 по экономике и эконометрике и топ-100 по политологии и международным исследованиям.

Тем временем представляем новый номер журнала.

В рубрике «Новые тексты» мы публикуем статью сотрудников Центра сравнительных исторических и политических исследований Пермского государственного национального исследовательского университета, кандидата политических наук $A$. $B$. Семёнова и кандидата политических наук $B$. Д. Бедерсона, в которой описывается реакция организаций российского третьего сектора на введение в июле 2012 г. реестра организаций, «выполняющих функции иностранного агента». На основе организационной теории и теории ресурсной зависимости анализируется политика «лицензирования» организаций гражданского общества и усиление государственного регулирования сектора, предлагается типология некоммерческих организаций в зависимости от обеспеченности ресурсами и правил доступа к ним. Эмпирическим материалом исследования послужили 19 интервью с лидерами и активистами российских НКО в девяти регионах России. Показывается, что российские НКО демонстрируют значительную степень жизнестойкости и адаптируются к средовым изменениям, в том числе через диффузию организационных форм, позволяющих минимизировать издержки от законодательных новаций.

В рубрику «Расширение границ» мы включили перевод первой главы книги Э. Б. Аткинсона (19442017; профессор Лондонской школы экономики и Оксфордского университета) «Что такое “неравенство”, и можем ли мы его преодолеть?», которая готовится к изданию в Институте им. Е. Т. Гайдара. Автор пытался решить задачу по уменьшению неравенства в распределении доходов, которое в настоящее время приобрело невероятные масштабы. Аткинсон основывает свои рассуждения на исторических данных, охватывающих столетний период эволюции современных обществ. В публикуемой первой главе («Предварительные установки») идёт речь о понятии «неравенство», о масштабах этого явления, о множестве значений неравенства и необходимости решить вопросы, касающиеся его основных параметров. Публикуется с разрешения Издательства Института им. Гайдара.

В рубрику «Дебюты» помещена статья А. А. Андреевой, Ю. Д. Климешовой, М. А. Кудрявцевой и А. П. Лобановой (студенты НИУ ВШЭ) «Рационализация жизни современного человека на примере анализа потребления воды жителями Москвы». Авторы указывают на трансформацию практик потребления воды в современной России и связь этого явления с нарастающей рационализацией повседневности. Исследование опирается на 26 глубинных интервью, проведённых в Москве. Показано как формируются механизмы контроля над потреблением воды, произведена калькуляция его объёма, зависящая от стремления привести потребление к «заданной» норме. 
В рубрике «Профессиональные обзоры» публикуется подготовленный П. А. Поповой (НИУ ВШЭ) аналитический обзор экономических, психологических и социологических концепций, объясняющих финансовые конфликты в семье. Автор пытается ответить на вопрос о том, как возникают финансовые конфликты, и рассматривает эмпирические исследования, посвящённые супружеским конфликтам и месту проблемы денег в их возникновении. С помощью теорий семейных систем, семейного стресса, социального обмена, распределения благ и ролевой теории выявляются предположительные предикторы, которые могут объяснить финансовый конфликт в семье.

В рубрике «Новые книги» кандидат исторических наук Н. В. Конрой (научный сотрудник ЛЭСИ НИУ ВШЭ) предлагает рецензию «Разумный альтруизм: можно ли примирить мораль и рынок?» на книгу Жужи Беренд «The Online World of Surrogacy» (New York; Oxford: Berghahn Books, 2016). Эта книга - результат десятилетней этнографии речевого поведения необычной группы, которая называла себя «удивительные женщины SMO». Речь идёт об одном из самых продолжительных исследований американского суррогатного материнства и одновременно социальной динамики онлайн-дискуссий. Участницы форума «Surrogate Mothers Online» (SMO) обсуждали понимание родительства и материнства, работы и отношений, контракта и денег, товара и дара. Суррогатные матери и бездетные пары через Интернет пытались договориться о моральном содержании этих понятий в контексте рыночных отношений.

В рубрике «Конференции» мы анонсируем ряд секций XVIII Международной научной конференции по проблемам развития экономики и общества, которая состоится 11-14 апреля 2017 г. Её проводит Национальный исследовательский университет «Высшая школа экономики» при участии Всемирного банка. Председателем Программного комитета конференции традиционно является профессор Е. Г. Ясин. Из предварительной программы мы выбрали секции, которые, на наш взгляд, могут быть наиболее интересны для экономсоциологов.

В разделе на английском языке в рубрике «Интервью» публикуется беседа с Питером Швейцером (профессор факультета социальной и культурной антропологии Университета Вены). Он рассказывает о своих исследованиях Сибири и Арктического региона. Они начались с изучения примитивных сообществ охотников и собирателей на Чукотке и в Республике Саха. В настоящее время П. Швейцер реализует международный исследовательский проект «Конфигурация отсталости», анализирующий процессы строительства Байкало-Амурской магистрали как образец воздействия крупного проекта транспортной инфраструктуры на экологические и социальные условия жизни в регионе. Исследование фокусируется на мобильности и социальности людей, проживающих в зоне строительства БАМа, и проблематизирует явление «отсталости» через изучения мобильности и социальности строителей БАМа. На более общем уровне Швейцер обсуждает «онтологический поворот» в текущих антропологических дебатах. Интервью записано Е. Гудовой (ЛЭСИ НИУ ВШЭ).

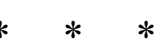

Ещё раз поздравляем всех наших коллег из Высшей школы экономики с включением университета в список топ-100 по социологии глобального предметного рейтинга QS. 


\section{VR INTRODUCTORY REMARKS}

\section{Dear Colleagues,}

We are pleased to inform you that the Higher School of Economics reached the Sociology top 100 in this year's global QS World University Rankings by Subject. This is a great achievement, as the HSE is the only Russian university to score that high in the Rankings. Overall, HSE was rated in 13 QS subjects for 2016, including top 100 scores in Economics and Econometrics and in Politics and International Studies.

Now we turn to the new issue of the journal.

Andrei Semenov (from the Center for Comparative History and Politics) and Vsevolod Bederson (Assistant Professor, Department of Political Science, Perm State University) present a study examining organizational reactions in the Russian third sector to adoption of the so-called "Foreign Agents" law in July 2012. Within the framework of organizational and resource dependence theories, they analyze state "licensing" policy in relation to civil society organizations and the tightening of regulation in this sector. Empirical data from interviews with 19 representatives of NGOs in nine regions of Russia reveal that these organizations have shown a great degree of resilience in adapting to these changes through diffusion of organizational form to minimize the costs of new legislation.

In the section "Beyond the Borders," we publish a Russian translation of the first chapter of the book Inequality: What Can be Done? (Cambridge, MA; London: Harvard University Press, 2015). The author, A. B. Atkinson, (Centennial Professor at the London School of Economics and Fellow of Nuffield College, Oxford) discusses the issue of increasing inequality in the distribution of income in the contemporary world, based on historical data covering more than a century of evolution. In the published chapter ("Setting the Scene"), the author defines the notion of inequality and asserts the need to resolve issues related to the main parameters of inequality. The chapter is published with kind permission of the Gaidar Publishing House.

Anastasia Andreeva, Julia Klimeshova, Maria Kudryavtseva, and Anastasia Lobanova co-authored "Rationalization of Modern Life: The Case of Water Consumption in Moscow." The study investigates how the increasing rationalization of everyday life has transformed water consumption practices. Data from 26 in-depth interviews demonstrate how the mechanisms of control and calculative behavior are manifested in both the conscious and unconscious strategies (such as measuring tactics) developed by Muscovites to increase the volume of water consumed.

Polina Popova (Department of Sociology, Higher School of Economics) reviews economic, psychological, and sociological theories of financial disagreements within families in an attempt to explain how financial conflicts arise, examining empirical studies of family conflicts and how money problems contribute to them. Drawing on theories of family systems, family stress, social exchange, distribution of benefits, and role theory, she explores the conflict formation process and possible predictors of financial conflict within the family.

Natalia Conroy (LSES, HSE) presents a review of Zsuzsa Berend's book The Online World of Surrogacy (NY, Oxford: Berghahn Books, 2016). Based on a decade-long ethnographic study of writing behavior among a "self-selected group of amazing women" (the SMO'ers), this is the longest extant study of both American surrogacy and the social dynamics of online discussions. The patterns of discussions initiated by the SMO'ers related to parenting and motherhood, work and relationships, contracts and money, goods and gifts, as surrogate mothers and childless couples sought to negotiate online the moral significance of these concepts in the context of market rationality, and to develop a win/win project, bringing a new life into the world. 
The journal also includes information on a number of sessions of the forthcoming XVIII International Conference on Modernization of Economy and Society (April 11-14, 2017), hosted by the National Research University's Higher School of Economics. The Program Committee is chaired by Professor Yevgeny Yasin. After screening the draft program, we selected sessions likely to be of most interest to economic sociologists.

\section{Texts in English}

Peter Schweitzer (Professor at the Department of Social and Cultural Anthropology, University of Vienna) was interviewed in Vienna in December 2016. He talks about his studies in Siberia and the Arctic region, which started from an exploration of hunting and gathering societies of Chuckotka and Sakha regions and led him to the University of Alaska Fairfax. Schweitzer's current international project, "Configuration of Remoteness," analyzes the construction of the Baikal-Amur Mainline [BAM] as an example of the influence of transportation infrastructure on the ecological and social conditions of life in the region. The research focuses on the "mobility" and "sociality" of people living in the vicinity of BAM construction and questions the development of "remoteness" through shifts in the mobility and sociality of BAM builders. In broader terms, Schweitzer discusses the "ontological turn" in ongoing anthropology debates. The interview was recorded by Elena Gudova (NRU HSE).

Once again, our congratulations to all our colleagues from the Higher School of Economics on reaching the top 100 in Sociology in the QS Global Subject Rankings. 


\section{НОВЫЕ ТЕКСТЫ}

\section{А. В. Семёнов, В. Д. Бедерсон \\ Организационные реакции российских НКО на законодательные изменения 2012 г.1}

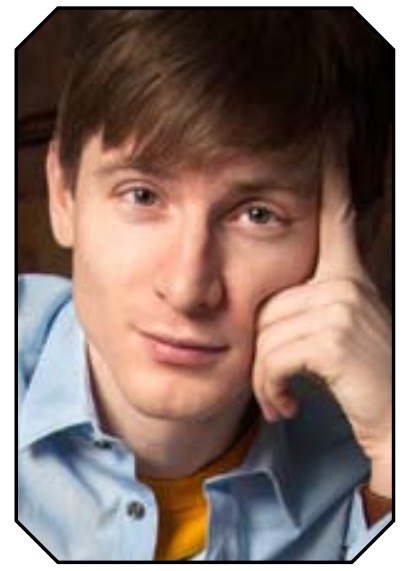

СЕМЁНОВ Андрей Владимирович кандидат политических наук, директор Центра сравнительных исторических и политических исследований ПГНИУ, доцент кафедры политических наук ПГНИУ. Адрес: 614990, Россия, Пермь, ул. Букирева, 15.

Email: andreysemenov@ comparativestudies.ru
В настоящей статье исследуется реакиия организаций российского третьего сектора на введение в июле 2012 г. реестра организаџий, «выполняющуих функиии иностранного агента». На основе организационной теории и теории ресурсной зависимости анализируется политика «лицензирования» организаций гражданского общества и усиления государственного регулирования сектора, предлагается типология некоммерческих организачий в зависимости от обеспеченности ресурсами и правил доступа к ним. На основе типологии сравниваются реакиии российских НКО на изменения в потоках ресурсов и на правоприменительную практику законодательства о так называемых иностранных агентах. Эмпирическим материалом исследования послужили 19 интервью с лидерами и активистами российских НКО в девяти регионах России, данные официальной статистики (Министерство юстиции, Министерство экономического развития, Общественная палата РФ), внутренние документы НКО и материаль СМИ. Основной аргумент статьи заключается в том, что растущее государственное вмешательство в сектор через изменения средь оказывает всё большее формирующее воздействие на организационную динамику независимо от типа НКО. Введение реестра организащий, «выполняющих функции иностранного агента», значимо влияет на взаимодействие между государством, бизнесом и третьим сектором, ограничивая и затрудняя доступ к ресурсам для сектора в иелом; компенсируюшие меры в виде увеличения государственного финансирования стали замещающим ресурсом, доступ $\kappa$ которому обусловлен рядом обстоятельств, в частности политической лояльностью НКО. Кроме того, для некоторых организаџий изменение в потоках ресурсов и правилах доступа к ним является существенным барьером для профессионализащии. Однако российские НКО демонстрируют значительную степень жизнестойкости и адаптируются к средовым изменениям, в том числе посредством диффузии организационных форм, позволяющих минимизировать издержки от законодательных новаций.

Ключевые слова: гражданское общество; некоммерческие организации; третий сектор; организационная теория; организационная адаптация; Россия.

Статья выполнена в рамках Программы развития партнёрских центров Европейского университета в Санкт-Петербурге. Авторы признательны Элеоноре Минаевой за помощь в сборе интервью и двум анонимным рецензентам за отзывы на первоначальную версию статьи. 


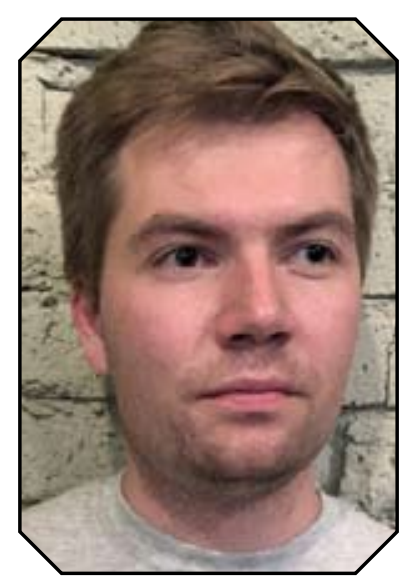

БЕДЕРСОН Всеволод Дмитриевич -

кандидат политических наук, младший научный сотрудник Института философии и права УрО РАН, старший преподаватель кафредры политических наук ПГНИУ, сотрудник Центра сравнительных исторических и

политических исследований ПГНИУ. Адрес: 620990, Россия, г. Екатеринбург, ул. Софьи Ковалевской, 16.

Email: vsbederson@ gmail.com

\section{Введение}

Государственное регулирование третьего сектора в России стало одним из направлений политики Владимира Путина, начиная со второго президентского срока: опыт «цветных революций» в странах бывшего советского блока, в которых независимые некоммерческие организации сыграли важную роль, а также соображения «национальной безопасности» определили движение в сторону от подхода laissez-faire к регулированию третьего сектора и все большим его ограничениям, «лицензированию» гражданского общества [Robertson 2009]. Принятие поправок в законы «Об общественных объединениях» и «О некоммерческих организациях» (2006), создание Общественной палаты (2006), развитие государственной финансовой поддержки НКО (так называемые президентские гранты), создание специального статуса и перечня социально ориентированных НКО и их финансовая поддержка со стороны правительства РФ (2010) и, наконец, законы об «иностранных агентах» и «нежелательных организациях» (2012 и 2015) значительно трансформировали как третий сектор в целом, так и отдельные типы организаций. Эти трансформации изменили потоки ресурсов, доступных для третьего сектора, правила доступа к ним, разделив НКО на те, которые имеют преференциальный доступ к государственному и другим видам финансирования, и те, доступ которым ограничен.

Вопросы ресурсной обеспеченности, общественной поддержки, государственного надзора над НКО существовали и до упомянутых изменений [Evans, Henry, Sundstrom 2006], однако основные перемены связаны с ужесточением регулирования сектора начиная с 2006 г.: согласно докладу Общественной палаты о состоянии гражданского общества за 2014 г. [Доклад... 2014], количество НКО в России в 2012-2014 гг. сократилось на 33\%, в том числе в Северо-Западном федеральном округе - на 35\%, в Дальневосточном и Южном округах — на 32\%, в Уральском - на 37\%, в СевероКавказском - на 33\% [Доклад... 2014] 2 . По данным Министерства юстиции РФ, по состоянию на декабрь 2012 г. были зарегистрированы 402 тыс. НКО и 319 представительств иностранных некоммерческих организаций, а в январе 2015 г. - лишь 223,6 тыс., или 56\% от количества 2012 г. [Минюст... $2015]^{3}$. Эксперты указывают, с одной стороны, на растущее давление со стороны государства, а с другой - на то, что статистика не вполне отражает реальное положение дел, так как одни организации третьего сектора (например, «ГОЛОС») самоликвидировались, а другие продолжили свою деятельность в качестве неформальных объединений [Вандышева 2014]. Иными словами, организации третьего сектора по-разному реагировали на средовые изменения в ресурсных потоках и на регулирование доступа

2 Примечательно, что доклад Общественной палаты за 2015 г. вообще не отмечает динамику в численности НКО в целом, останавливаясь только на заметном росте количества «социально ориентированных» НКО [Доклад... 2015].

3 Вероятно, большая часть ликвидированных НКО не были активными и являлись «организациями на бумаге», однако исследований, которые могли бы подтвердить или опровергнуть данное предположение, не проводилось. Изучение изменений в третьем секторе Эфиопии после принятия схожего по смыслу закона показывает, что депопуляция «НКО на бумаге» оказалась наиболее видимой [Dupuy, Ron, Prakash 2015]. 
к ним. Что определяло реакцию российских НКО на эти изменения, и, в частности, как российские НКО приспосабливались организационно к изменениям законодательства, особенно к закону о так называемых иностранных агентах? В данной статье мы попытаемся ответить на этот вопрос на основе организационной теории.

Исследователи третьего сектора, в принципе, отмечают, что организации по-разному взаимодействуют со средой. Один из самых распространённых способов объяснения различий - классификация организаций по типу ресурсной зависимости на низовые, правительственные и международные. Такая схема применялась к российскому [Henry 2006; Crotty, Hal, Ljubownikow 2014] и другим контекстам [Yu 2016], однако эти типологии являются индуктивными и строятся на одном измерении. Следуя теориям открытых организаций и ресурсной зависимости, мы предлагаем собственную типологию НКО на основе двух измерений: потоков ресурсов и правил доступа к ним. В рамках данного подхода на материалах интервью с представителями некоммерческих организаций, на статистических данных о развитии третьего сектора и исходя из средств массовой информации мы проверяем ряд предположений о связи между внешними изменениями, типами организаций и реакциями организаций российского третьего сектора. В начале статьи мы предложим объяснительную схему, затем проанализируем общую траекторию развития третьего сектора в России с 2006 г., наконец, рассмотрим результаты опроса представителей третьего сектора по поводу организационной адаптации.

\section{Ресурсная зависимость, средовые фракторы и организационные изменения}

В организационной теории источники изменений атрибутируются либо акторам внутри коллективных образований (рациональная теория организации), либо средовым факторам (теории открытых систем, ресурсной зависимости, популяционной экологии, институционализм). Рациональная теория предполагает, что лидеры в целях максимизации целевых установок изменяют структуру организаций, а также внутриорганизационные правила и рутины; средовые факторы данной теорией, по большему счету, игнорируются [Scott, Davis 2015]. Однако эмпирические исследования показывают, что организации не являются автономными единицами с непроницаемыми для среды границами, но активно взаимодействуют с окружением и меняются под его влиянием [Pfeffer, Salancik 2003; Aldrich 2008]. Так, экологическая теория организаций обращает внимание на наличие отдельных «ниш», которые создаются вокруг потоков ресурсов и существуют в виде относительно автономных полей взаимодействия [Hannan, Carroll, Pólos 2003; Радаев 2005, Валитова, Тамбовцев 2005; Хэннан, Фримен 2013]. Институциональная теория отводит особую роль нормам, символам и когнитивным схемам, их распространению в «организационных полях» при объяснении организационных изменений [Мейер, Роуэн 2011]. Теория ресурсной зависимости утверждает, что «среда влияет на организации посредством предоставления и (или) удержания ресурсов», а организационные формы, в свою очередь, могут быть ранжированы «в терминах эффективности добычи ресурсов» [Pfeffer, Salancik 2003: 61].

Несмотря на то что организационная теория в первую очередь была направлена на изучение коммерческих фирм, исследователи третьего сектора также отмечали её полезность [Powell, Steinberg 2006]. Применительно к России, в литературе о некоммерческих организациях организационная теория не получила широкого распространения, в том числе для разработки типологий некоммерческих организаций.

Так, Л. Генри разделяет некоммерческие организации на «низовые», «профессиональные» и «аффилированные с правительством» [Henry 2006], Дж. Кротти с соавторами - на «марионеточные», «низовые» и «традиционные» [Crotty, Hal, Ljubownikow 2014], А. Ю. Сунгуров предложил выделять классы НКО в зависимости от целевых групп этих организаций («НКО взаимопомощи», «НКО клубного типа», «благотворительные», «экологические», «правозащитные», «инфраструктурные» [Сунгуров 2008]). Данные типологии, несмотря на их эвристическую значимость, являются, скорее, следстви- 
ем эмпирических наблюдений и не выводятся из существующих теорий организаций. Основываясь на представлении об организациях как об открытых системах [Scott, Davis 2015], мы полагаем, что организационные формы и тип реакции на внешние изменения связаны с ресурсной зависимостью организации, а также с дифференциацией в правилах доступа к ресурсам, которая определяется государственной политикой регулирования сектора.

Теории открытых систем и ресурсной зависимости предполагают, что организации представляют собой сочетания потоков и активностей, встроенных в материально-ресурсную и институциональную среды [Scott, Davis 2015]. Ресурсы и институты, таким образом, оказывают формирующее воздействие на основные характеристики организаций: объём ресурсов и правила доступа к ним и (или) правила их использования определяют возможности организации (штат сотрудников, офис, функциональная дифференциация ролей, взаимодействие с ключевыми группами интересов и т.д.). Для построения типологии ${ }^{4}$ НКО мы используем два измерения: характеристики (1) потоков ресурсов и (2) правил доступа к ним. Первое измерение связано с ресурсной обеспеченностью (разнообразие и объём источников финансирования), второе - со степенью государственного регулирования деятельности, а более конкретно - с внесением в реестр организаций, «выполняющих функции иностранного агента» ${ }^{5}$. Таким образом, наша схема включает четыре типа организаций (см. таблицу 1).

Таблица 1

Классификации организаций по объёму ресурсов и правилам доступа

\begin{tabular}{ccc}
\hline Организационный тип & Правила доступа не ограничены & Правила доступа ограничены \\
\hline Низкоресурсные & Низовые гражданские инициативы & Организации защиты прав \\
& меньшинств \\
Высокоресурсные & Поциально ориентированные НКО & Экологическе НКО \\
& Правительственные НКО & Благотворительные НКО \\
& Религиозные НКО \\
\hline
\end{tabular}

Приведённая в таблице 1 классификация отражает в том числе тенденции развития российского третьего сектора. Так, в исследовании Кротти и её коллег утверждается: уход западных доноров сделал государство основным проводником финансовых ресурсов (процесс, который подробнее рассматривается в следующем разделе данной статьи), что в итоге должно привести к росту популяции «марионеточных» организаций [Crotty, Hal, Ljubownikow 2014]. Кроме того, ужесточение регулирования третьего сектора привело к вытеснению «независимых» организаций [Gilbert 2016] и к созданию неблагоприятных условий для НКО, выступающих с критикой в отношении государственной власти [Flikke 2016].

Каким образом данная типология может быть связана с реакцией на средовые изменения, в частности на изменения в законодательство об НКО? Мы полагаем, что для организационного типа с финансовой независимостью и отсутствием ограничений (сектор с низовыми неформальными группами) существенной организационной реакции ожидать не приходится в силу их временного характера, а также невозможности применения к ним принудительных мер. Организации из противоположного сектора (плотные потоки ресурсов, активное вмешательство государства, особенно после закона об «иностранных агентах»), очевидно, больше всего заинтересованы в адаптации, особенно в создании защитных механизмов. Менее очевидны направления реакции у организаций из двух оставшихся ниш. Можно

4 В более ранней версии статьи мы предположили, что данный классификатор может служить основанием для выделения «организационных ниш», однако ограничения в данных пока не позволяют подтвердить это предположение.

5 Определяется п. 6 ст. 2 Федерального закона «О некоммерческих организациях» (№ 7-Ф3). 
предположить, что сектор с «правительственными» и социально ориентированными НКО в меньшей степени отреагирует на средовые изменения, как и низкоресурсные организации, не подпавшие под закон об «иностранных агентах»: у первых нет достаточного стимула, у вторых - ресурсов для соответствующих изменений. Тем не менее, поскольку законодательство касается не только отдельных организаций, но поля в целом, организационные изменения должны затронуть весь третий сектор.

\section{Методы сбора и обработки данных}

Чтобы охарактеризовать реакцию российских НКО на изменения в поле, нам понадобились, во-первых, реконструкция контекста средовых изменений, в частности изменений в законодательном регулировании третьего сектора и потоках ресурсов, во-вторых, данные об организационных реакциях отдельных НКО. Для решения второй задачи в течение августа 2015 г. - февраля 2016 г. были проведены полуструктурированные интервью с лидерами и (или) сотрудниками некоммерческих организаций и неформальных гражданских инициатив из Перми (восемь интервью), Тюмени (четыре интервью), Москвы (одно интервью), Ижевска (одно интервью), Иркутска (одно интервью), Калининграда (одно интервью), Петрозаводска (одно интервью), Краснодара (одно интервью), Кирова (одно интервью), то есть всего 19 интервью с представителями 17 НКО и одной неформальной инициативы (в одной НКО были проведены два интервью - с руководителем и сотрудником). Выборка НКО формировалась таким образом, чтобы охватить все организационные типы, а также на основании дополнительных критериев - длительность существования, тематику деятельности (сектор), включённость и (или) не- включённость в реестр так называемых иностранных агентов (см. приложение) ${ }^{6}$. Внутри организаций интервью проводились в основном с руководителями (в двух случаях - с заместителями руководителя).

Гайд проведённых полуструктурированных интервью представлял собой вопросы, укладывающиеся в следующие блоки:

— общие тенденции взаимодействия со средой и (или) /государством;

- горизонтальное взаимодействие в секторе;

- организационные шаблоны и практики;

— воздействие изменений в законодательстве.

Кроме того, мы основывались на вторичных данных, касающихся информации в отношении российского третьего сектора, объёмов государственного финансирования, данных аналитических центров, Общественной палаты РФ, Министерства юстиции РФ и др. [«Иностранные агенты»... 2015; Доклад... 2014; Развитие... 2016]. Интервью и вторичные данные позволили зафиксировать как индивидуальные организационные траектории, так и адаптационные стратегии. Нас интересуют оба вопроса, поскольку адаптационная стратегия является прямым продолжением организационной траектории, которая, согласно нашей модели, зависит от типа НКО. Для того чтобы оценить источник организационного развития НКО, мы задавали респондентам вопросы о том, откуда берутся организационные шаблоны, какое влияние оказывает государство на внутриорганизационные правила и рутины, какие организации являются образцовыми и почему, а также ряд вопросов о внутриорганизационных процессах.

\section{Изменение организационной среды российского третьего сектора во второй половине 2000-х - первой половине 2010-х гг.}

Во второй половине 2000-х гг. происходят значительные изменения в третьем секторе с точки зрения как ресурсной обеспеченности, так и государственного регулирования. Западные доноры, доминировавшие в

6 Чтобы гарантировать анонимность респондентов, названия и местоположение организаций не указываются. 
1990-е гг. и в первой половине 2000-х гг., вынуждены были сократить своё присутствие, а законодательство и правоприменение существенно ограничили возможности НКО в плане выбора организационных форм и доступа к ресурсам. Изменения в государственном регулировании начались в 2005-2006 гг.: в ноябре 2005 г. в Государственной Думе прошло первое чтение законопроекта, касающегося регулирования деятельности некоммерческих организаций, в частности вопросов регистрации, финансирования и отчётности. Инициаторы законопроекта - депутаты фракции «Единая Россия», сославшись на международный опыт и необходимость закрыть «пробел в законодательстве», чтобы предупредить «произвол чиновников», заявили, что цель проекта - «точно прописать права (HКО) и точно прописать возможности влияния государства на эти организации» [Стенограмма... 2005]. Обсуждение в первом чтении приняло довольно острый характер: ряд депутатов высказались резко против, указав на отрицательные отзывы на законопроект представителей третьего сектора, а также чрезмерное увеличение контрольных и надзорных функций в отношении НКО; депутаты фракций «Родина», ЛДПР и «Единая Россия» проект закона поддержали, аргументируя это необходимостью бороться с противоправными действиями общественных организаций, в частности в случае, если они финансируются из-за рубежа [Стенограмма... 2005].

Уже в декабре 2005 г. законопроект был принят в третьем чтении: 357 голосов «за», 20 - «против», 7 воздержались. Вскоре, 10 января 2006 г, закон был подписан президентом и вступил в силу 18 апреля. Ни общественное [Закон... 2006; Рошаль... 2006], ни международное [ПАСЕ... 2006] давление не помогло не только предотвратить или отложить принятие, но и сколь-либо сбалансировать содержание закона [О внесении... 2006]. Решимость сторонников ужесточения регулирования деятельности НКО была поддержана скандалом со «шпионским камнем» [Тони Блэр... 2012] и нашла поддержку в общественном мнении: согласно опросу исследовательского холдинга «РОМИР», 67\% россиян поддержали закон. Основания для усиления контроля респонденты в основном связали с тем, что «меценаты зачастую преследуют свои политические цели, не всегда очевидна налоговая чистота» [Россияне... 2006]. Таким образом, политические элиты и население согласились, что третий сектор представляет собой опасность для политического режима и потому нуждается в контроле. Депутат А. Макаров ещё при первом чтении законопроекта признал, что «деятельность некоммерческих и общественных организаций - этот вопрос, безусловно, всегда будет связан с политикой» [Стенограмма... 2005].

Эксперты Международного центра некоммерческого права в отзыве на законопроект прямо указали, что он «предусматривает чрезмерное вмешательство государства во внутренние дела организаций, что противоречит статье 11 ЕКПЧ о праве на ассоциации» [Анализ закона... 2006]. В ещё одном докладе отмечалось, что «после вступления в силу поправок значительно увеличились издержки (денежные и временные) регистрации некоммерческой организации» [Экономические последствия... 2007]. Так, подготовка документов для регистрации новой НКО и процедура внесения изменений в уставные документы существующей НКО повлекли перераспределение финансовых затрат НКО ввиду необходимости получения профессиональной юридической консультации или передачи этой функции внештатным юристам; сроки государственной регистрации или внесения изменений удлинились, что вылилось в увеличение издержек. Изменившиеся требования к отчётности также вызвали финансово-временные издержки со стороны НКО, связанные с поиском новых сотрудников (бухгалтер, юрист, делопроизводитель) и (или) вложений в переобучение имеющихся сотрудников. Наконец, одним из значимым следствий закона № 18 для третьего сектора стали государственные проверки, которые были возложены на Росрегистрацию ${ }^{7}$. Авторы аналитической записки отмечают, ссылаясь на результаты опроса НКО, что проверки стали стрессом для организаций ввиду отсутствия у сотрудников ФРС специфических знаний о некоммерческом секторе, потенциальном повышении коррупционности в отношениях НКО и ФРС, а также обращают внимание на длительность и забюрократизированность самой процедуры проверки и др. [Экономические последствия... 2007].

7 Федеральная регистрационная служба, ФРС. 
Пристальное и направленное внимание государства к НКО несколько ослабилось во время президентства Дмитрия Медведева. Однако уже в 2012 г. был принят закон, вносящий новые поправки в законодательство о некоммерческих организациях в части введения реестра «НКО, выполняющих функции иностранных агентов». Закон требует, чтобы НКО, которые получают финансирование от любой иностранной организации, в любых объёмах и подпадают под определение «ведение политической деятельности», подавали заявление в Министерство юстиции о включении в данный реестр. Если НКО не входит в реестр добровольно, то она может быть включена в него по решению Минюста, а за нарушение может быть наложен штраф как на саму НКО, так и на руководителя. Депутаты Государственной Думы, которые стали инициаторами принятия данного закона, при объяснении актуальности закона ссылались на американский закон о регистрации иностранных агентов - Foreign Agents Registration Act (FARA), принятый в эпоху маккартизма, но без указания на то, что после поправок 1966 г. FARA стал инструментом противостояния иностранным коммерческим лоббистам [Гордеева 2016а].

Ключевой проблемой российского аналога американскому закону стало отсутствие чётко прописанного определения «политическая деятельность». Это дало возможность надзорным органам вменить ряду НКО нарушение закона, объяснив их политическую активность проведением семинаров, круглых столов, экспертных заключений и даже интервью сотрудников в СМИ, - всё это было истолковано как попытка повлиять на изменение государственной политики в той или иной сфере ${ }^{8}$. Противники данного закона предпринимали попытки смягчения его действия путём уточнения понятия «политическая деятельность»: были предложены проекты соответствующих поправок в закон Комитетом гражданских инициатив, Клубом юристов НКО, отдельными региональными уполномоченными по правам человека, что обсуждалось на уровне президентского Совета по развитию гражданского общества и правам человека [Обсуждение... 2015]. В 2016 г. новые поправки в закон об НКО, уточняющие понятие «политическая деятельность», были приняты, но, по мнению экспертов, они только закрепили существующую судебную практику широкой трактовки этого понятия [Гордеева 2016b; Мухаметшина 2016].

Издержки этого закона на организационном уровне, как и в случае закона 2006 г., связаны с дополнительным государственным контролем: НКО-«иностранные агенты» должны дважды в год («обычные» НКО - один раз в год) сдавать Минюсту подробную содержательную и финансовую отчётность о своей деятельности, проводить обязательный финансовый аудит (раньше обязательное требование было только для НКО в форме фондов), маркировать любую свою информационную продукцию соответствующим грифом, а также подвергаться дополнительным проверкам со стороны Минюста. К моменту подготовки данной статьи реестр «иностранных агентов» состоял из $192 \mathrm{HКО,} \mathrm{наделённых} \mathrm{таким} \mathrm{ста-}$ тусом; из реестра исключены 17 организаций в связи с тем, что они пререстали получать иностранное финансирование, и 25 НКО в связи с ликвидацией организации [Сведения реестра... 2017]. Общественное мнение в отношении закона 2012 г. схоже с позицией 2006 г.: результаты опросов, проведённых «Левада-центром», показывают, что россияне поддержали меры в отношении НКО [Россияне... 2013]. Несогласие с законом или с отдельными его установками стало предметом обсуждения в экспертных кругах, массового интереса к проблеме НКО ужесточение нормативной базы не вызвало.

Параллельно с ужесточением регулирования происходили серьёзные изменения в ресурсных потоках. Прямым следствием вступления в силу закона 2006 г. для третьего сектора стало сокращение финансирования от иностранных доноров: часть этих последних прекратили проекты в России (Фонд Форда, позже - Агентство США по международному развитию (United States Agency for International Development - USAID), программа Маtra посольства Королевства Нидерландов, Фонд Мотта), боль-

8 См. подробнее, например, историю судебного противостояния Пермской гражданской палаты и Прокуратуры Пермского края: [Тихонович 2013]. 
шинство - существенно уменьшили объёмы своей работы (Фонд Макартуров и др.). В 2015 г. был принят закон о так называемых нежелательных организациях (Федеральный закон от 23.05.2015 № 129 Ф3 «О внесении изменений в отдельные законодательные акты Российской Федерации»), который, в принципе, запретил получать финансирование от организаций, представляющих угрозу национальной безопасности России. Государство выступило источником замещающего финансирования и постепенно увеличивало собственное присутствие в третьем секторе: с 2007 г. стала действовать президентская программа распределения грантов организациям, «участвующим в развитии гражданского общества», по которой выделялся 1 млрд руб. в год в 2007-2012 гг., а затем объём резко вырос и составил порядка 4,6 млрд руб. в 2016 г. (см. рис. 1). Кроме того, государство стало выделять финансовые средства для социально ориентированных (СО) НКО через отдельные министерства и ведомства, в частности проводить конкурсы на государственные субсидии Министерства экономического развития [Ежегодный доклад... 2016]. Общий объём государственного финансирования СО НКО в 2016 г. превысил 7,2 млрд руб. [О состоянии... 2016].

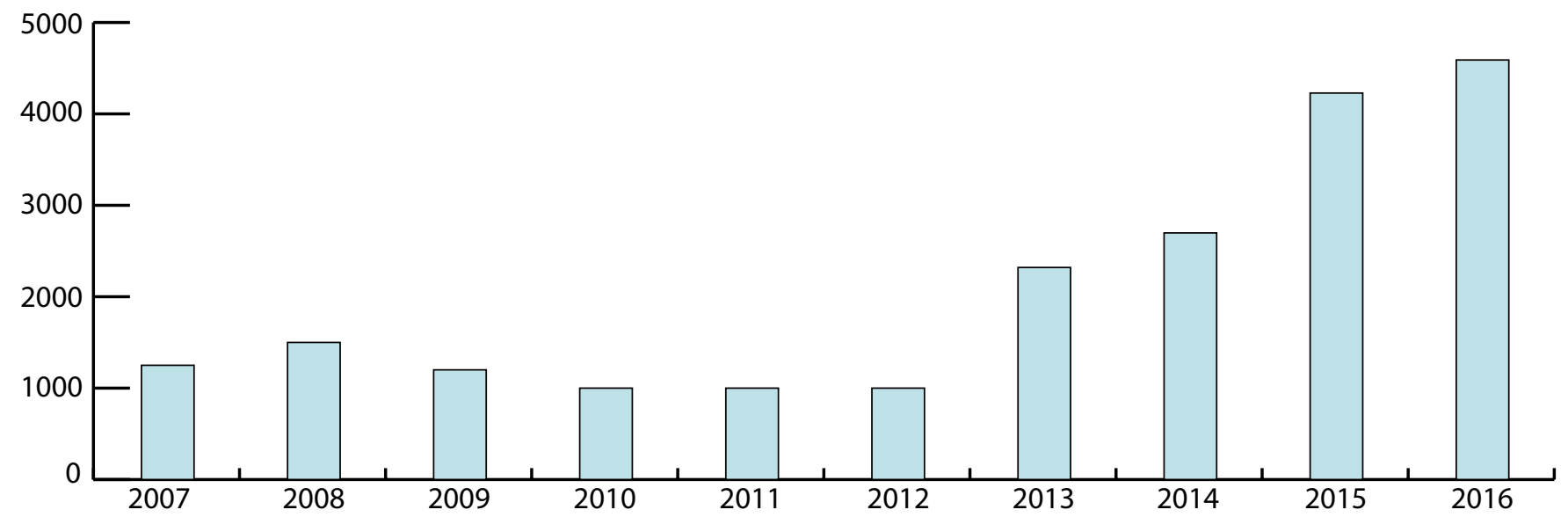

Источник: Официальный сайт президента PФ. URL: www.kremlin.ru

Рис. 1. Объём финансирования НКО в рамках государственной поддержки НКО, участвующих в развитии гражданского общества, за 2007-2016 гг. (в млн руб.)

Таким образом, законодательные и режимные изменения 2006-2012 гг. окончательно закрепили политику «лицензирования» организаций гражданского общества в России. В условиях низкой общественной поддержки третьего сектора и государственной политики усиления регулирования НКО постепенно сокращались независимые потоки ресурсов и ужесточались правила доступа к ним, что в целом увеличивало трансакционные издержки на деятельность НКО. Ожидаемо изменения в среде разделили совокупность организаций на те, которые имеют преференциальный доступ к новому источнику ресурсов (в основном СО НКО и «правительственные» НКО), и те, кому доступ как к традиционным, так и к новым ресурсным потокам оказался ограничен. В следующем разделе мы анализируем организационные траектории развития различных типов НКО и стратегию их адаптации к изменившимся условиям, а далее обратим внимание на реакцию на законодательные изменения 2012 г.

\section{Организационные траектории НКО в меняющейся среде}

Изменения в ресурсных потоках и правилах доступа к ним в российском третьем секторе стали отправной точкой нашего анализа. На момент проведения интервью опрошенные нами организации находились на разных стадиях своего развития (от закрытия организации до роста), и их представители открыто отмечали противоречие между необходимостью профессионализации деятельности и средовыми ограничениями (ресурсы и издержки на ведение деятельности). На основе ответов можно ре- 
конструировать естественную, с точки зрения респондентов, логику организационного развития НКО от неформального волонтёрского сообщества, «низовой» инициативы к профессиональной, часто экспертной, некоммерческой организации. Такая логика особенно заметна в рассуждениях тех респондентов, которые представляют относительно недавно юридически оформленные НКО. Они отмечают, что изначально их организации существовали в качестве неформального сообщества взаимопомощи, ситуативных совместных действий, однако в дальнейшем их организации профессионализировались, что проявлялось в найме специалистов (как правило, юристов и бухгалтеров, иногда - более узких специалистов (психологов, медиков и др.) в зависимости от тематики деятельности), а также в аренде офисных помещений для постоянного присутствия и ведения консультаций (приема) для целевой аудитории организации. Завершающим критерием профессионализации часто выступает внешняя «сертификация» (например, приглашение представителей организации в качестве экспертов для комментариев в СМИ или на какие-либо совещательные площадки - форумы, круглые столы, общественные советы при органах власти и т. п.) или работа с публичной властью. Так, представитель организации, осуществляющей поддержку семей с детьми-инвалидами, отмечает, что всё начиналось с «сообщества активистов-родителей», затем образовалось юридическое лицо, был нанят штатный юрист, а в дальнейшем стали «принимать участие или организовывать площадки с представителями родителей и органов власти» (респондент G).

Несмотря на признание важности профессионализации как приоритета организационного развития, реальные траектории исследованных нами НКО значительно различаются. Так, наибольшая предрасположенность к профессионализации проявляется у организаций в высокоресурсных полях, что во многом обусловлено требованиями доноров, как частных, так и государственных. Представитель организации-фонда местных сообществ, существующей с 1999 г. и имеющей большой опыт в реализации в том числе международных проектов, отмечает:

\section{Мы сразу делали ставку на профессиональный подход (респондент $B$ ).}

Состав организации стабилен на протяжении многих лет, в ней традиционно существует разделение функциональных обязанностей персонала, есть множественные источники финансирования и ведётся проектная деятельность на постоянной основе. Ещё один случай: организация - ресурсный центр (существует с 2000 г.), сравнительно небольшая (в штате - руководитель, консультант и бухгалтер). Глава этой организации отмечает, что в связи с недостатком ресурсов и в некоторой степени нежеланием расширяться «по многим направлениям [сотрудникам] приходится быть универсальными; это не позволяет развивать специализацию, профессионализацию» (респондент $R$ ). Интересно, что почти все представители организаций данного типа, несмотря на отсутствие давления со стороны государства, отмечают сокращение ресурсов и повышение зависимости от государственного финансирования.

Ресурсные организации в нашей выборке, в отношении которых действуют ограничения, также зачастую развивались от неформальной инициативы в сторону профессионализации. В одном из интервью представитель просветительской общественной организации (существует с 1999 г.) описывает траекторию следующим образом:

Первоначально организачия создавалась как клуб по интересам: друзья детства создали, закончили разные вузы в разных городах, вернулись в [родной город], собирались пообщаться, совместно провести досуг. Через год-два организащия стала соџиально ориентированной, профессионально заниматься адвокатированием (респондент $D$ ).

В дальнейшем организация была внесена принудительно в реестр «иностранных агентов» и существенно сократила свою деятельность. Особенность данного типа организаций в том, что они, как пра- 
вило, имеют длительную историю существования, в результате чего их представители указывают на обилие организационных правил и рутин. Одна из правозащитных и просветительских НКО данного типа формально состоит из двух разных юридических лиц (из двух организаций, одна из которых в настоящее время признана «иностранным агентом» и самоликвидировалась), но это разделение не имеет большого значения, как отмечает в интервью руководитель. Особенность стратегического управления в организации заключается в структуре и работе правления. Во-первых, оно состоит из 26 человек, что исключительно много и нетрадиционно для российских НКО [Мерсиянова, Якобсон 2007]; в заседаниях правления принимают участие и простые члены организации (они имеют право высказывать своё мнение, но лишены права голоса). Во-вторых, правление занимается широким кругом вопросов, которые традиционно не выносятся на заседания (например, подготовка тех или иных заявок на гранты и т. п.). В-третьих, правление старается принимать решение не большинством голосов, а консенсусно, из-за чего заседания правления представляют собой многочасовые обсуждения всех достоинств и недостатков того или иного решения. Такое особенное правление может быть также интерпретировано в качестве организационного церемониалаю С одной стороны, он усложняет процессы принятия решений и снижает эффективность организации, а с другой стороны, такая консенсусная форма управления может, как писали Мейер и Роуэн, снижать турбулентность и повышать институциональную устойчивость организации [Мейер, Роуэн 2011: 148]. Представители других организаций из этой ниши также отмечали значимость внутренних правил, хотя степень жёсткости их применения варьируется от чёткой регламентированности всего рабочего процесса до констатации того, что формальные нормы могут быть замещены более гибкими.

Проблема профессионализации организации является вызовом для низкоресурсных организаций: сказываются отсутствие необходимых средств и стимулов, а также государственная политика. Так, представитель низовой инициативы отмечал, что после первых успешных проектов группы перед членами сообщества встал вопрос об организационном будущем:

У нас неоднократно возникали споры, стоит ли нам регистрировать организацию или нет. Но организачия на нас налагает непосильные для такого объединения, как мы, обязательства, при этом преимущества, которые мы получим, неочевидны (респондент $K$ ).

Группа решила не образовывать юридическое лицо, что, в свою очередь, означало не подпадать под организационную, административную и финансовую зависимость от государства, взамен обладать большой независимостью, но высокими рисками стабильности группы. В результате инициатива просуществовала лишь два года — 2012-2014 гг.

Ещё один пример - созданная в 2009 г. организация по защите прав меньшинств. Её особенность состоит в том, что она является отделением общероссийской организации. Это перекладывает часть рисков, связанных с характером деятельности, на центральный офис. Руководитель этой НКО отмечает значимость ресурсов в повышении качества работы: появление финансирования открывало возможность найма штатных специалистов, однако средства выделяются на год, что создаёт неопределённость. Существенным ресурсом для организации являются волонтёры, которые помогают в проведении мероприятий (респондент B2).

Организации из низкоресурсных ниш с ограничениями в доступе (в нашей выборке их оказалось три) сочетают элементы профессиональных организаций из ресурсных ниш с характеристиками неформальных инициатив: правовой статус им нужен, как правило, чтобы иметь стабильный источник средств, которых обычно не хватает для полноценной организационной работы. Показателен случай экологической организации, испытавшей на себе сокращение ресурсной базы, а затем - действие закона об «иностранных агентах». Её представитель отмечает: 
Были времена, когда по сто человек в проектах работали в штате, это было в конще 1990-х годов < ... П Постепенно деятельность сжималась, в том числе из-за недостатка финансирования (респондент $V$ ).

Интересно, что в этой организации, как и в случае с вышеупомянутой правозащитной и просветительской организацией, принятие решений было консенсус-ориентированным:

Коллективная система принятия решений, не дай бог кому-то не расскажешь что-то, со всеми этими гримасами демократии, обсуждениями, консенсусами (респондент $V$ ).

Последние пять лет организация испытывала серьёзные финансовые проблемы, также были прокурорские проверки, в результате чего организация прекратила своё существование. Другая организация этого типа, испытавшая на себе воздействие закона, также не смогла продолжить свою деятельность, а её руководитель отмечает, что проблемы возникли ещё до включения в реестр:

Скорее всего, организаџия к этому шла, не было смены поколений, произошла некая стагнация, некий такой знак < .. > что надо закрыть и начать с чистого листа (респондент $C$ ).

В целом тема ресурсов и сужения или расширения доступа к ним выступает одной из центральных во всех интервью, даже если респондентам не задавали сфокусированные на этой теме вопросы. Практически все респонденты подтверждают, что в последние годы увеличивается доля государственного финансирования сектора: для кого-то это дополнительные возможности (одной из молодых и низкоресурсных организаций президентские гранты позволили создать веб-присутствие и выпускать печатную продукцию, а еще одна из добровольческих организаций приобрела транспортное средство для волонтёров); кто-то видит в расширении государственного присутствия опасность. Представитель ресурсного центра даёт следующую оценку этому процессу:

Большой поток государственных денег - это президентские гранты, МЭР (Министерство экономического развития. - Авторы.) (гранты, субсидии), партнёрские проекты с другими регионами, межрегиональные. Я вижу в этом определённую опасность, эта игла, зависимость от государственного финансирования; привыкая к определённым источникам финансирования, отвыкаешь от других и перестаёшь на них ориентироваться. Государство шаг за шагом предъявляет новые требования, новые правила, акценты и приоритеты (респондент T).

В то же время усиление государственного регулирования - один из факторов, подталкивающих НКО к профессионализации, поскольку отчётность по государственным грантам и проверки создают необходимость найма специалистов (юристов и бухгалтеров) для работы в данном направлении. Более того, отмечается, что государство лучше понимает, как взаимодействовать со сколько-нибудь формальной, бюрократической структурой, нежели с неформальным активистским сообществом. Аналогичные последствия наблюдались и в связи с присутствием международных доноров, но государственное влияние на организационные траектории явно сильнее. С одной стороны, усиление регулирования и изменения в потоках ресурсов приводят к снижению эффективности (больше времени уходит на отчёты и другие нецелевые виды деятельности), с другой стороны, некоторые респонденты отмечали появление «новых инструментов взаимодействия с властью» (респондент $Z$ ) и стимулов для более плотной работы с третьим сектором, спускаемых «сверху» на региональный и местный уровни. 


\section{Организационные реакции НКО на закон об «иностранных агентах» 2012 г.}

Как указывалось выше, закон об «иностранных агентах» вызвал широкий резонанс в среде НКО: против него выступал Совет по правам человека, была подана жалоба в Европейский суд по правам человека, несколько организаций, внесённых в реестр, оспаривали свой статус в суде (некоторые - например Центр гражданского анализа и независимых исследований, ГРАНИ - получили положительное решение по своему иску), а в феврале 2016 г. Верховный суд Татарстана по инициативе Минюста РФ ликвидировал ассоциацию правозащитных организаций «АГОРА». Авторы доклада «Развитие гражданского активизма вопреки»» зафиксировали интересную тенденцию: в 2015-2016 гг. при проверках Минюстом некоммерческих организаций, имеющих иностранное финансирование, НКО после получения извещения о проверке подавали в исполнительный орган заявление о включении организации в реестр «иностранных агентов», тем самым пытаясь избежать значительного денежного штрафа за «нарушение закона» [Развитие... 2016: 4]. Юридически такой шаг со стороны НКО необязательно имел ожидаемый эффект, поскольку Минюст мог всё равно наложить штраф за нарушение сроков вхождения в реестр, но сама практика (согласно докладу, так поступили около десятка НКО) показывает, как быстро распространяются механизмы организационной адаптации среди российских НКО. В докладе также отмечается, что в некоторых случаях такое «добровольное» вхождение в реестр в момент проверки Минюста было результатом торга между НКО и надзорным органом: «Входите в реестр, а мы не взыщем штраф» [Развитие... 2016: 5].

Закон об «иностранных агентах» не ограничивается штрафами как инструментом воздействия; другие меры включают выселение из офиса, арест имущества, судебное преследование, очередные и внеочередные проверки, привлечение руководителя организации к ответственности, ликвидацию НКО, обвинения НКО в подрыве конституционного строя, отказ исключить НКО из реестра, широкое трактование политической деятельности и др. Ряд мер расценивался и анализировался в научных работах в качестве государственного давления на некоммерческий сектор [Вандышева 2014; Flikke 2016]. На основании проведённых нами интервью и анализа вторичных данных можно выделить три ключевые группы мер государственного воздействия на НКО в рамках закона об «иностранных агентах»:

- uтрафы и иные меры финансового давления. Как уже отмечалось, закон об «иностранных агентах» предполагает значительные денежные штрафы для НКО за нарушение положений этого закона. Штраф может быть взыскан через суд Минюстом как с юридического лица (с самой НКО), так и с физического лица (с руководителя организации). Наши респонденты отмечали, что данная мера государственного давления является значительной с точки зрения устойчивости организации, размеры штрафов (500 тыс. и 300 тыс. руб.) для бюджетов российских региональных НКО представляют серьёзный вызов, составляя от трети до половины ежегодного бюджета (см. приложение). Риск получения штрафа ставит перед НКО задачу оптимизации финансовой политики, особенно с учётом того, что, как правило, бюджеты НКО представляют собой совокупность бюджетов грантов, все расходы по которым вписаны в ту или иную бюджетную строку, требующую отчёта перед донором. Иными словами, у НКО нет в наличии свободных средств, из которых можно было бы оплатить штраф. Исключение составляют те организации, которые, помимо грантовой деятельности, оказывают какие-либо платные услуги. Таким образом, угроза штрафа является сильным механизмом государственного контроля за НКО: организации, принимая этот риск, вынуждены перестраивать внутренние финансовые порядки, перераспределять средства, создавать резервы для оплаты штрафов;

- проверки со стороны Минюста, прокуратуры и иные меры организащионного давления. Большинство респондентов называли плановые или внеочередные проверки НКО со стороны надзорных органов одной из самых тяжёлых мер. Респонденты-руководители отмечали, что на 
подготовку к проверке и устранение выявленных замечаний организации вынуждены затрачивать значительные человеческие и временные ресурсы, данные меры «часто отвлекают сотрудников от основной деятельности организации, заставляя сосредоточиваться на делах, связанных с проверкой» (респондент R). Кроме того, целый ряд организаций отметили, что были включены в реестр в результате «неожиданных» проверок Минюста, а одной из организаций сообщили, что её включают в реестр в связи с необходимостью «выполнить план по иностранным агентам в регионе» (респондент В);

- стигматизаџия, публичное информаџионное давление. Данная категория мер имеет исключительно политическую природу и может быть понята в свете трансформации политического режима в России после событий 2014 г. [Гельман 2015]. Как отмечали в своём открытом обращении представители ряда пермских НКО, которым угрожало включение в реестр, «называться иностранными агентами для наших организаций - оскорбительная неправда» [Пермские НКО... 2013]. Фонд «Общественный вердикт» после включения в реестр опубликовал заявление, в котором указывалось: «Навязывание нам ярлыка иностранного агента рассчитано на то, что мы не будем пользоваться поддержкой наших сограждан и не сможем и дальше защищать их право не подвергаться произволу со стороны правоохранительных органов» [Атака... 2014]. Репутационные последствия для сектора ощутили на себе и наши респонденты, которые отмечали, что выросло недоверие внутри сектора, а также в отношениях с чиновниками. Даже организации, которые закон не затронул, отмечают:

Потом появилась «иностранное агентство», нам стали говорить, что мы когда-то получали иностранное финансирование, они стали нас бояться, осторожно относиться (респондент $B$ ).

В некоторых случаях накопленный символический капитал позволял скомпенсировать репутационные издержки; например, представитель организации, включённой в список, отмечала в интервью:

Все понимают, смирились, нас по-прежнему приглашают на какие-то круглье столь, мероприятия <...>. Не все, конечно, но те, с кем мы сотрудничали раньше, понимают всю абсурдность этой ситуации (респондент $D$ ).

Однако такая ситуация, скорее, исключение из общей тенденции.

Основываясь на проведённых интервью и анализе вторичных источников, мы приводим ниже варианты реакций на изменения в законодательстве (соотнесение организационных типов и реакций представлено в таблице 2):

— лояльность характерна для НКО, тесно вплетённых в отношения с региональными властями и имеющих значительное государственное финансирование. В одном из интервью отмечалось:

Mы выполняем этот закон об иностранных агентах, мы везде публикуем, даже на каких-то листовках мелким шрифтом, что организация внесена в этот список. Мы будем потихоньку вспльвать и делать это осторожно (респондент $D$ ).

Реагируя таким образом, НКО, как правило, стремятся сохранить поддержку государства и при этом выйти из реестра «иностранных агентов». В интервью с руководителями таких НКО отмечалось, что после включения в реестр рутинная деятельность организации существенно 
менялась под нужды обеспечения проверок, новых отчётов Минюсту и судебного оспаривания получения статуса в ущерб принципиальным целям организации;

- осторожность свойственна тем НКО, которые не попали под статус «иностранного агента» (в силу отсутствия в текущий момент и на момент проверок иностранного финансирования), а также представителям неформальных инициативных групп. В интервью респонденты из таких организаций отмечали, что их положение достаточно зыбкое и статус может легко поменяться в любой момент, как только они получат на свои счета иностранные средства. Во многих интервью с представителями данных НКО говорилось о том, что их положение во многом зависит от благосклонности региональных властей (респонденты G2, T, M). На организационном уровне эти НКО не претерпели изменений, а часть из них, как отмечалось выше, даже предприняли шаги в сторону профессионализации, однако часто высказывалась мысль о финансовом ухудшении положения дел в некоммерческом секторе ввиду сокращения потенциальных доноров;

- полная ликвидация. Одна из организаций, где проходили наши интервью, приняла решение о полной ликвидации деятельности, что предполагает прекращение активности, роспуск штата и волонтёров, перераспределение имущества и т. п. В интервью отмечалось, что не только статус «иностранного агента» стал причиной принятия решения о ликвидации, но и другие причины: невозможность привлекать финансирование и выплачивать заработную плату, сохранить офис, а также административные препятствия со стороны региональных органов власти;

- формальная ликвидация. Отреагировавшие таким образом НКО приняли решение юридически ликвидировать организацию, но сохранить свою активность в качестве неформальной группы активистов. Это пример «обратной профессионализации»: принимается решение избавиться от «признаков» профессиональной НКО (штат, офис, органы управления), но сохраняется активность, пусть и в неформальном статусе, берёт на себя риски, связанные с отсутствием институционального финансирования и сотрудничества с государством в качестве юридического лица;

- перерегистращия. Типичные и публично известные примеры такой реакции - формально новые организации старых команд ассоциации «ГОЛОС», которая перерегистрировалась в качестве общественного движения, и ассоциации «АГОРА», которая теперь действует в качестве иностранной некоммерческой организации, не имея формального статуса, офиса, штата в РФ. Такая реакция на средовые изменения позволяет организации, понеся финансовые, репутационные и организационные издержки, сохранить активность и продолжить работу;

- институциональное сопротивление предполагает, что юридически организация продолжает существовать, более того публично заявляет о своём несогласии с включением в реестр «иностранных агентов» и через суд оспаривает решение Минюста. Часть НКО, отреагировавших подобным образом, в настоящее время исключены из реестра, однако такая реакция потребовала значительных усилий и внутренних организационных трансформаций с целью минимизации новых рисков от средовых изменений. Помимо судебной защиты, некоторые прибегли к созданию «холдингов» - одной или нескольких «дочерних» НКО; на них планируется получать иностранное финансирование, и они могут стать «иностранными агентами», тем самым формально защитив «материнскую» организацию. Также создаются коммерческие организации, которые не могут быть включены в реестр «иностранных агентов». Кроме того, ресурсные организации стали уделять особое внимание вопросам безопасности и публичного присутствия организации. 
Соотнесение организационных типов и реакций

Таблица 2

\begin{tabular}{ccc}
\hline Организационный тип & Правила доступа не ограничены & Правила доступа ограничены \\
\hline Низкоресурсные & Осторожность & Лояльность \\
& & Осторожность \\
Высокоресурсные & Перерегистрация \\
& Лояльность & Полная ликвидация \\
& Осторожность & Формальная ликвидация \\
& Перерегистрация \\
\hline
\end{tabular}

Ожидаемо, что организационные реакции больше всего проявляются у тех НКО, которые оказались непосредственно затронуты законодательными изменениями, однако представители остальных организаций также вынуждены адаптироваться к новым условиям. Низовые инициативы оказываются определённой альтернативой для небольших организаций: отсутствие регистрации позволяет им оставаться «ниже радара» и избегать нежелательного контроля. Нестабильным является положение низкоресурсных организаций с ограниченным доступом, которым закон 2012 г. создал дополнительные барьеры для ведения деятельности и поиска доноров. В одном из интервью представителя такой организации ситуация была охарактеризована так:

Мы не можем планировать на пять лет вперёд. Сама неопределённая ситуация, общественнополитическая, она держит нас в неопределённости (респондент $R$ ).

Такая «неопределённая ситуация» может быть рассмотрена также как мера государственного контроля, вынуждающая НКО «оглядываться» на отношение к ней государственных органов.

Организации, которые закон 2012 г. затронул непосредственно, но которые оказались ресурсно обеспеченными, добавляют к стандартному репертуару реакций «формальную ликвидацию» и «институциональное сопротивление». Однако таких организаций в общем числе включённых в реестр совсем немного. Ресурсные организации без ограничений в доступе, казалось бы, должны больше всех выиграть от снижения конкуренции и увеличения доступных для них ресурсов. И действительно, представитель одной из таких НКО отмечает:

Изменения произошли, появились какие-то деньги, больше стало государственного финансирования, гранты, субсидии, также деятельность, приносящая доход, -она опосредована из государственных источников, нашими клиентами являются организачии-получатели государственных денег в том или ином виде (респондент T).

В то же время, как отмечалось выше, государственное финансирование не всегда воспринимается НКО как благо; отмечается, что новое законодательство приводит к «преследованиям и даже травле» (респондент Z).

\section{Дискуссия и заключение}

Проведённое исследование демонстрирует важность дифференциации организаций третьего сектора в объяснении динамики их организационного развития и взаимодействия с государством, донорами и ключевыми партнёрами. Организационная теория и теория ресурсной зависимости дают возможность проанализировать воздействие средовых изменений, оставляя за скобками вопрос о нормативной оцен- 
ке данных изменений, которая связывает третий сектор с концептом «гражданское общество». Наблюдаемые процессы замещения независимых источников финансирования государственными, а также ограничение доступа к ресурсам для некоторых групп создают «победителей» и «проигравших», то есть оказывают дифференциирующее воздействие на сектор. Данный вывод согласуется с растущим корпусом исследований НКО в режимах «соревновательного авторитаризма», которые демонстрируют, что правительства таких режимов заинтересованы не столько в тотальном подавлении любых гражданских инициатив, сколько в направленном контроле над ними, в том числе с целью собственной легитимации [Richter, Hatch 2013; Lorch, Bunk 2016]. Доступность ресурсов для организаций в таких условиях становится одним из определяющих факторов выживания [Hsu 2010; Dupuy, Ron, Prakash 2015; Yu 2016].

Россия не представляет исключения из этого тренда. В исследовании регионального разреза отношений государства и НКО в современной России И. Краснопольская, Ю. Скокова и У. Пейп анализируют механизмы грантовой поддержки (субсидии Министерства экономического развития РФ на поддержку социально ориентированных НКО) региональными правительствами социально ориентированных НКО [Krasnopolskaya, Skokova, Рape 2015] и приходят к выводу, что во взаимодействии государства и НКО на региональном уровне преобладает модель кооптации: региональные власти перераспределяют федеральные субсидии НКО, с одной стороны, с целью политической легитимации, а с другой — для реализации своих обязательств в социальной политике. Таким образом, региональные власти заинтересованы в создании условий для лояльных НКО, способных выступать младшими партнёрами. Подобную логику развивают А. Тарасенко и М. Кулмала, изучившие деятельность ветеранских организаций Санкт-Петербурга и Республики Карелия с точки зрения теории клиентелизма и показавшие, что ветеранские организации являются брокерами социальной политики регионов, то есть обеспечивают политическую поддержку и способствуют проведению государственных социальных программ, направленных на свою целевую группу [Тарасенко, Кулмала 2015].

Проведённое исследование даёт некоторые основания полагать, что российские НКО считывают сигнал «лояльность в обмен на ресурсы». Организации, которые ценят автономию, в итоге приходят к модели, позволяющей оставаться «ниже радара» и минимизировать контакт с государством ценой ограничения источников ресурсов, тем самым фактически обрекая себя на статус локальных инициатив. Организации, чья деятельность требует других масштабов работы, вынуждены подчиняться требованиям государства либо вести неравную борьбу за изменение правил доступа к ресурсам. Означает ли это, что российский третий сектор будет окончательно поглощён государством, то есть «марионеточные» НКО будут безоговорочно доминировать [Crotty, Hal, Ljubownikow 2014]? Нам представляется, что положительный ответ на данный вопрос преждевременен: в организационном плане российский третий сектор выработал значительный потенциал жизнестойкости и, вопреки средовому давлению, имеет возможность адаптироваться к изменениям. Вариация приспосабливаемости внутри каждого из типов НКО, а также роль контекстуальных факторов (особенности регионов с их различиями в политическом режиме, социальном капитале и уровне экономического развития, роль лидеров и их ценностных ориентаций, взаимозависимость между организациями в одной «экологической нише») выступают важными направлениями последующих исследований. 


\section{Приложение}

Организационные данные НКО респондентов и статус в реестре организаций, выполняющих функции иностранных агентов

\begin{tabular}{|c|c|c|c|c|c|c|c|}
\hline $\begin{array}{c}\text { Организация } \\
\text { (№ присвоен } \\
\text { случайно) } \\
\end{array}$ & $\begin{array}{l}\text { Средний } \\
\text { годовой } \\
\text { бюджет } \\
\end{array}$ & $\begin{array}{c}\text { Источники финансиро- } \\
\text { вания }\end{array}$ & $\begin{array}{l}\text { Стаж рабо- } \\
\text { ты органи- } \\
\text { зации } \\
\end{array}$ & $\begin{array}{l}\text { Размер орга- } \\
\text { низации: штат; } \\
\text { команда (чел.) } \\
\end{array}$ & «Иностранный агент» & Тип реакции & Респондент \\
\hline 1 & $\begin{array}{l}\text { Нет инфор- } \\
\text { мации }\end{array}$ & $\begin{array}{l}\text { Частные пожертвования } \\
\text { Иностранные доноры }\end{array}$ & $\begin{array}{l}\text { C } 1998 \text { г., } \\
\text { старая }\end{array}$ & 12 & $\begin{array}{l}\text { Включена в реестр, ликвиди- } \\
\text { рована, исключена из рее- } \\
\text { стра в связи с ликвидацией }\end{array}$ & $\begin{array}{l}\text { Формальная } \\
\text { ликвидация }\end{array}$ & Респондент $G$ \\
\hline 2 & 1,5 млн руб. & $\begin{array}{l}\text { Гранты и (или) субсидии } \\
\text { государства } \\
\text { Иностранные доноры } \\
\text { Членские взносы } \\
\text { Частные пожертвования }\end{array}$ & $\begin{array}{c}\text { С } 1999 \text { г., } \\
\text { старая }\end{array}$ & 25 & $\begin{array}{l}\text { Включена в реестр, исклю- } \\
\text { чена в связи с прекращением } \\
\text { иностранного финансирова- } \\
\text { ния }\end{array}$ & Лояльность & Респондент $D$ \\
\hline 3 & 1,1 млн руб. & $\begin{array}{l}\text { Иностранные доноры } \\
\text { Российские фонды }\end{array}$ & $\begin{array}{l}\text { С } 1992 \text { г., } \\
\text { старая }\end{array}$ & 5 & $\begin{array}{l}\text { Включена в реестр, ликвиди- } \\
\text { рована, исключена из рее- } \\
\text { стра в связи с ликвидацией }\end{array}$ & $\begin{array}{l}\text { Перерегистра- } \\
\text { ция }\end{array}$ & Респондент $C$ \\
\hline 4 & 1,5 млн руб. & $\begin{array}{l}\text { Государственные гранты } \\
\text { и (или) субсидии }\end{array}$ & $\begin{array}{l}\text { С } 2001 \text { г., } \\
\text { старая }\end{array}$ & 5 & Не включалась в реестр & Осторожность & Респондент $T$ \\
\hline 5 & 1,8 млн руб. & $\begin{array}{l}\text { Государственные гранты } \\
\text { и (или) субсидии } \\
\text { Иностранные доноры }\end{array}$ & $\begin{array}{l}\text { С } 2000 \text { г., } \\
\text { старая }\end{array}$ & 4 & Не включалась в реестр & Осторожность & Респондент $R$ \\
\hline 6 & $\begin{array}{c}\text { Нет инфор- } \\
\text { мации }\end{array}$ & $\begin{array}{l}\text { Государственные гранты } \\
\text { и (или) субсидии } \\
\text { Иностранные доноры }\end{array}$ & $\begin{array}{l}\text { С } 2004 \text { г., } \\
\text { старая }\end{array}$ & 15 & Включена в реестр & $\begin{array}{l}\text { Институцио- } \\
\text { нальное со- } \\
\text { противление }\end{array}$ & Респондент $P$ \\
\hline 7 & 1,3 млн руб. & $\begin{array}{l}\text { Государственные гранты } \\
\text { и (или) субсидии } \\
\text { Частные пожертвования } \\
\text { Личные средства }\end{array}$ & $\begin{array}{l}\text { С } 2013 \text { г., } \\
\text { новая }\end{array}$ & 12 & Не включалась в реестр & Осторожность & Респондент $G$ \\
\hline
\end{tabular}


Таблииа П.1. Продолжение

\begin{tabular}{|c|c|c|c|c|c|c|c|}
\hline $\begin{array}{l}\text { Организация } \\
\text { (№ присвоен } \\
\text { случайно) } \\
\end{array}$ & $\begin{array}{l}\text { Средний } \\
\text { годовой } \\
\text { бюджет }\end{array}$ & $\begin{array}{c}\text { Источники финансиро- } \\
\text { вания }\end{array}$ & $\begin{array}{c}\text { Стаж рабо- } \\
\text { ты органи- } \\
\text { зации }\end{array}$ & $\begin{array}{c}\text { Размер орга- } \\
\text { низации: штат; } \\
\text { команда (чел.) }\end{array}$ & «Иностранный агент» & Тип реакции & Респондент \\
\hline 8 & 0,7 млн руб. & $\begin{array}{l}\text { Иностранные доноры } \\
\text { Государственные гран- } \\
\text { ты и (или) субсидии } \\
\text { Частные пожертвования } \\
\text { Коммерческая деятель- } \\
\text { ность некоммерческой } \\
\text { организации }\end{array}$ & $\begin{array}{l}\text { С } 1990 \text { г., } \\
\text { старая }\end{array}$ & 21 & $\begin{array}{l}\text { Включена в реестр, ликвиди- } \\
\text { рована, исключена из рее- } \\
\text { стра в связи с ликвидацией }\end{array}$ & $\begin{array}{l}\text { Полная ликви- } \\
\text { дация }\end{array}$ & Респондент $V$ \\
\hline 9 & 2,2 млн руб. & $\begin{array}{l}\text { Государственные гранты } \\
\text { и (или) субсидии } \\
\text { Частные пожертвования }\end{array}$ & $\begin{array}{l}\text { С } 1999 \text { г., } \\
\text { старая }\end{array}$ & 6 & Не включалась в реестр & $\begin{array}{l}\text { Лояльность / } \\
\text { Осторожность }\end{array}$ & Респондент $B$ \\
\hline 10 & 1 млн руб. & $\begin{array}{l}\text { Иностранные доноры } \\
\text { Личные средства }\end{array}$ & $\begin{array}{l}\text { С } 2009 \text { г., } \\
\text { новая }\end{array}$ & 5 & Не включалась в реест & Осторожность & $\begin{array}{c}\text { Респондент } \\
\text { В2 }\end{array}$ \\
\hline 11 & 1,8 млн руб. & $\begin{array}{l}\text { Иностранные доноры } \\
\text { Государственные гранты } \\
\text { и (или) субсидии }\end{array}$ & $\begin{array}{l}\text { С } 2004 \text { г., } \\
\text { старая }\end{array}$ & 8 & Не включалась в реестр & Осторожность & Респондент $L$ \\
\hline 12 & 16 млн руб. & $\begin{array}{l}\text { Иностранные доноры } \\
\text { Государственные гранты } \\
\text { и (или) субсидии } \\
\text { Коммерческая деятель- } \\
\text { ность некоммерческой } \\
\text { организации }\end{array}$ & $\begin{array}{l}\text { С } 2007 \text { г., } \\
\text { старая }\end{array}$ & 16 & $\begin{array}{l}\text { Включена в реестр, исклю- } \\
\text { чена в связи с прекращением } \\
\text { иностранного финансирова- } \\
\text { ния }\end{array}$ & $\begin{array}{l}\text { Институцио- } \\
\text { нальное со- } \\
\text { противление }\end{array}$ & $\begin{array}{c}\text { Респондент } \\
\text { MI }\end{array}$ \\
\hline 13 & 21 млн руб. & $\begin{array}{l}\text { Частные пожертвования } \\
\text { Государственные гранты } \\
\text { и (или) субсидии }\end{array}$ & $\begin{array}{l}\text { С } 2012 \text { г., } \\
\text { новая }\end{array}$ & 9 & Не включалась в реестр & Осторожность & $\begin{array}{c}\text { Респондент } \\
\text { M2 }\end{array}$ \\
\hline 14 & 2 млн руб. & $\begin{array}{l}\text { Государственные гранты } \\
\text { и (или) субсидии }\end{array}$ & $\begin{array}{l}\text { С } 2006 \text { г., } \\
\text { старая }\end{array}$ & 15 & Не включалась в реестр & Лояльность & Респондент $Z$ \\
\hline 15 & $\begin{array}{c}\text { Нет инфор- } \\
\text { мации } \\
\end{array}$ & Личные средства & $\begin{array}{l}\text { С } 2012 \text { г., } \\
\text { новая }\end{array}$ & 6 & Не включалась в реестр & Осторожность & $\begin{array}{c}\text { Респондент } \\
T 2 \\
\end{array}$ \\
\hline
\end{tabular}


Таблица П.1. Окончание

\begin{tabular}{|c|c|c|c|c|c|c|c|}
\hline $\begin{array}{c}\text { Организация } \\
\text { (№ присвоен } \\
\text { случайно) }\end{array}$ & $\begin{array}{c}\text { Средний } \\
\text { годовой } \\
\text { бюджет }\end{array}$ & $\begin{array}{c}\text { Источники финансиро- } \\
\text { вания }\end{array}$ & $\begin{array}{c}\text { Стаж рабо- } \\
\text { ты органи- } \\
\text { зации }\end{array}$ & $\begin{array}{c}\text { Размер орга- } \\
\text { низации: штат; } \\
\text { команда (чел.) }\end{array}$ & «Иностранный агент» & Тип реакции & Респондент \\
\hline 16 & $\begin{array}{l}\text { Нет инфор- } \\
\text { мации }\end{array}$ & $\begin{array}{l}\text { Частные пожертвования } \\
\text { Членские взносы } \\
\text { Коммерческая деятель- } \\
\text { ность некоммерческой } \\
\text { организации } \\
\text { Государственные гранты } \\
\text { и (или) субсидии }\end{array}$ & $\begin{array}{l}\text { С } 1992 \text { г., } \\
\text { старая }\end{array}$ & 6 & Не включалась в реестр & $\begin{array}{l}\text { Лояльность } \\
\text { и (или) осто- } \\
\text { рожность }\end{array}$ & Респондент $K$ \\
\hline 17 & 5 млн руб. & $\begin{array}{l}\text { Государственные гранты } \\
\text { и (или) субсидии } \\
\text { Иностранные доноры } \\
\text { Частные пожертвования } \\
\text { Коммерческая деятель- } \\
\text { ность некоммерческой } \\
\text { организации }\end{array}$ & $\begin{array}{l}\text { С } 2005 \text { г., } \\
\text { старая }\end{array}$ & 8 & $\begin{array}{l}\text { Включена в реестр, исклю- } \\
\text { чена в связи с прекращением } \\
\text { иностранного финансирова- } \\
\text { ния }\end{array}$ & Лояльность & Респондент $S$ \\
\hline 18 & 0,2 млн руб. & $\begin{array}{l}\text { Государственные гранты } \\
\text { и (или) субсидии }\end{array}$ & $\begin{array}{l}\text { С } 2014 \text { г., } \\
\text { новая }\end{array}$ & 7 & Не включалась в реестр & Осторожность & $\begin{array}{c}\text { Респондент } \\
\text { L3 }\end{array}$ \\
\hline
\end{tabular}




\section{Литература}

Анализ закона № 18-Ф3 «О внесении изменений в некоторые законодательные акты Российской Федерации». 2006. URL: http://www.strana-oz.ru/2005/6/analiz-zakona-no-18-fz-o-vnesenii-izmeneniy-vnekotorye-zakonodatelnye-akty-rossiyskoy-federacii

Атака на фонд. 2014. URL: http://publicverdict.ru/topics/ataka/11999.html

Валитова Л. А., Тамбовцев В. Л. 2005. Организационная экология: взгляд экономиста. Российский журнал менеджмента. 2: 109-118.

Вандышева Е. А. 2014. Стратегии НКО в связи с введением статуса «иностранного агента». Публичная политика - 2013. СПб.: НОРМА; 76-86.

Гельман В. 2015. Политика страха: как российский режим противостоит своим противникам. Контрапункт. 1 (сентябрь): 1-11. URL: http://www.counter-point.org/wp-content/uploads/2015/08/gelman counterpoint1.pdf

Гордеева Е. 2016а. Как стать предателем. Медуза. URL: https://meduza.io/feature/2016/04/20/v-borbe-svragami-postradali-druzya

Гордеева Е. 2016b. Просто больше будет бедных и больных. Медуза. URL: https://meduza.io/ feature/2016/02/20/prosto-bolshe-budet-bednyh-i-bolnyh

Давление на гражданское общество в России. 2016. URL: http://publicverdict.ru/articles_images/freedomof-assosiation_rus_nov212016.pdf

Доклад Общественной палаты РФ о состоянии гражданского общества в Российской Федерации. 2014. URL: http://pravorf.org/index.php/news/1388-o-doklade-obshhestvennoj-palaty-rf-o-sostoyaniigrazhdanskogo-obshhestva-v-rossijskoj-federaczii-za-2014-god

Доклад Общественной палаты РФ о состоянии гражданского общества в Российской Федеращии. 2015. URL: https://www.oprf.ru/files/1_2016dok/doklad_OPRF_2015_19012016.pdf

Ежегодный доклад Министерства экономического развития РФ о деятельности и развитии соииально ориентированных НКО в 2015 г. 2016. URL: http://nko.economy.gov.ru/PortalNews/Read/2934

Закон, ограничивающий деятельность НКО, вступит в силу в середине апреля. 2006. URL: http:// bellona.ru/2006/01/19/zakon-ogranichivayushhij-deyatelnost-n/

«Иностранные агенты»: мифические враги и реальные потери российского общества. 2015. СПб.: Автономная некоммерческая организация информационных и правовых услуг «Ресурсный правозащитный центр». URL: http://philanthropy.ru/wp-content/uploads/2015/03/Inostranny-e-agenty-.pdf

Коваль А. С., Иволга А. М., Ильиных И. И. 2014. Исследование информационной открытости системы распределения государственной поддержки НКО: 2011-2012. Под ред. Д. Я. Приимкова. Трансперенси Интернешнл-P. URL: http://nko67.ru/files/291/ngo_analisys_2014.pdf 
Мейер Д., Роуэн Б. 2011. Институционализированные организации: формальная структура как миф и церемониал. Экономическая соџиология. 12 (1): 43-67. URL: https://ecsoc.hse.ru/ data/2011/12/08/1259551850/ecsoc_t12_n1.pdf\#page $=43$

Мерсиянова И. В., Якобсон Л. И. 2007. Негосударственные некоммерческие организации: институизиональная среда и эффективность деятельности. М.: Изд. дом ВШЭ.

Минюст: в 2014 году в России зарегистрировано почти 100\% НКО, подавших заявления. 2015. TACC. URL: http://minjust.ru/ru/press/news/minyust-v-2014-godu-v-rossii-zaregistrirovano-pochti-100-nkopodavshih-zayavleniya

Мухаметшина Е. 2016. Минюст уточнил определение политической деятельности НКО для закона об иностранных агентах. Ведомости. № 4000 (25 января). URL: http:/www.vedomosti.ru/politics/ articles/2016/01/25/625267-opredelenie-deyatelnosti-nko

О внесении изменений в некоторые законодательные акты Российской Федерации. Федеральный закон № 18-Ф3. 2006. 10 января.

О состоянии гражданского общества в Российской Федеращии за 2016 год. Ежегодный доклад. 2016. М.: Общественная палата Российской Федерации.

Обсуждение понятия «политическая деятельность», разработанного Минюстом России в Совете при Президенте Российской Федераџии по развитию гражданского общества и правам человека. 2015. URL: http://president-sovet.ru/documents/read/432/

ПАСЕ: Закон об НКО не соответствует европейским нормам. 2006. URL: http://graniru.org/Politics/ World/Europe/m.101102.html

Пермские НКО отказались регистрироваться «иностранными агентами». 2013. URL: http://7x7journal.ru/item/28253

Портал грантов Общественной палаты РФ. 2016. URL: https://grants.oprf.ru/

Радаев В. В. 2005. Популяционная экология организаций: как возникает разнообразие организационных форм. Российский журнал менеджмента. 2: 99-108.

Развитие гражданского активизма вопреки: российские НКО после законодательства об «иностранных агентах». 2016. Доклад. Клуб юристов третьего сектора. URL: http://www.hro.org/files/2016_NLC_ report $\% 20$ on $\% 20 \mathrm{FA} \_$Rus.pdf

Россияне поддерживают жёсткие меры в отношении НКО. 2013. Известия. 11 июля. URL: http://www. levada.ru/2013/07/11/rossiyane-podderzhivayut-zhestkie-mery-v-otnoshenii-nko/

Россияне поддержали усиление контроля над НПО. Lenta.ru. 2006. URL: https://enta.ru/news/2006/03/16/ ngo/

Рошаль Л. 2006. Принятие закона об НКО является политической ошибкой. RBC.ru. URL: http://www. rbc.ru/rbcfreenews/20060121144150.shtml 
Сведения реестра НКО, выполняющих функции «иностранного агента». 2017. Информационный портал Министерства юстицฺии Российской Федераџии. URL: http://unro.minjust.ru/NKOForeignAgent. aspx

Стенограмма заседания Государственной Думы ФС РФ 23 ноября 2006 г. 2006. URL: https://docviewer. yandex.ru/?url=https $\% 3 \mathrm{~A} \% 2 \mathrm{~F} \% 2 \mathrm{Fnkozakon.ru} \% 2 \mathrm{Fwp}$-content $\% 2 \mathrm{Fuploads} \% 2 \mathrm{~F} 2005 \% 2 \mathrm{~F} 11 \% 2 \mathrm{~F} 63$. doc \&name $=63$. doc \&lang $=$ ru\& $\&=57$ ecd226a $8 \mathrm{de}$

Созаев В. 2010. ЛГБТ-движение в России: портрет в интерьере. Гендерные исследования. 21-22: 90126.

Сунгуров А. Ю. 2008. Структуры гражданского общества и их взаимодействие с властью в России. В кн.: В поисках гражданского общзества. Великий Новгород: НовГУ им. Ярослава Мудрого: 173208.

Тарасенко А., Кулмала М. 2015. Ветеранские организаџии как заинтересованные группы: возможности и ограничения клиентелизма для защиты сочиальных прав в регионах России. Препринт M-42/15. СПб.: Издательство Европейского университета в Санкт-Петербурге.

Тихонович Л. 2013. Пермская гражданская палата — не иностранный агент. Филантроп: электронный журнал о благотворительности. 17 июля. URL: http://philanthropy.ru/news/2013/07/17/12332/

Тони Блэр и шпионский камень: провал британских спецслужб в Москве. 2012. URL: http://www.rbc.ru/ society/19/01/2012/5703f1fe9a7947ac81a6403c

Усачева О. А. 2011. Экологический активизм в постсоветской России и западном мире (сравнительный анализ). Социологические исследования. 3: 23-31.

Хэннан М., Фримен Д. 2013. Популяционная экология организаций. Экономическая соииология. 14 (2): 42-72. URL: https://ecsoc.hse.ru/data/2013/04/05/1294839705/ecsoc_t14_n2.pdf\#page=42

Экономические последствия нового законодательства о некоммерческих организациях. Аналитическая записка. 2007. URL: http://www.socpolitika.ru/rus/ngo/documents/document812.shtml

Яницкий О. Н. 1995. Эволюция экологического движения в современной России. Социологические исследования. 8: 15-25.

Abou Assi K. 2013. Hands in the Pockets of Mercurial Donors: NGOs Response to Shifting Funding Priorities. Nonprofit and Voluntary Sector Quarterly. 42 (3): 584-602.

Aldrich H. 2008. Organizations and Environments. Redwood City: Stanford University Press.

Astley W. G. 1985. The Two Ecologies: Population and Community Perspectives on Organizational Evolution. Administrative Science Quarterly. 30 (2): 224-241.

Carroll G. R. 1985. Concentration and Dynamics of Niche Width in Populations of Organizations. American Journal of Sociology. 90: 1262-1283. 
Crotty J., Hall S. M., Ljubownikow S. 2014. Post-Soviet Civil Society Development in the Russian Federation: The Impact of the NGO Law. Europe-Asia Studies. 66 (8): 1253-1269.

DiMaggio P. J., Powell W. W. (eds). 1991. The New Institutionalism in Organizational Analysis. Vol. 17. Chicago, IL: University of Chicago Press.

Dupuy K., Ron J., Prakash A. 2015. Who Survived? Ethiopia's Regulatory Crackdown on Foreign-Funded NGOs. Review of International Political Economy. 22 (2): 419-456.

Evans A. B., Henry L. A., Sundstrom L. M. 2006. Russian Civil Society: A Critical Assessment. Abingdon, UK: M. E. Sharpe.

Flikke G. 2016. Resurgent Authoritarianism: The Case of Russia's New NGO Legislation. Post-Soviet Affairs. 32 (2): 103-131.

Gilbert L. 2016. Crowding Out Civil Society: State Management of Social Organisations in Putin's Russia. Europe-Asia Studies. 68 (9): 1553-1578.

Hannan M. T., Carroll G. R., Pólos L. 2003. The Organizational Niche. Sociological Theory. 21 (4): 309340.

Henry L. A. 2006. Shaping Social Activism in Post-Soviet Russia: Leadership, Organizational Diversity, and Innovation. Post-Soviet Affairs. 22 (2): 99-124.

Henry L. A. 2010. Red to Green. Environmental Activism in Post-Soviet Russia. Ithaca: Cornell University Press

Hsu C. 2010. Beyond Civil Society: An Organizational Perspective on State-NGO Relations in the People's Republic of China. Journal of Civil Society. 6 (3): 259-277.

Hydén G. 2006. Civil Society: What Next? Development Dialogue. 47 (1): 183-201.

Krasnopolskaya I., Skokova Y., Pape U. 2015. Government-Nonprofit Relations in Russia’s Regions: An Exploratory Analysis. VOLUNTAS: International Journal of Voluntary and Nonprofit Organizations. 26 (6): 2238-2266.

Lang S. 2012. NGOs, Civil Society, and the Public Sphere. Cambridge: Cambridge University Press.

Lorch J., Bunk B. 2016. Using Civil Society as an Authoritarian Legitimation Strategy: Algeria and Mozambique in Comparative Perspective. Democratization. 23 November: 1-19.

Powell W., Steinberg R. 2006. The Nonprofit Sector: A Research Handbook. New Haven: Yale University Press.

Pfeffer J., Salancik G. R. 2003. The External Control of Organizations: A Resource Dependence Perspective. Redwood City: Stanford University Press.

Richter J., Hatch W. F. 2013. Organizing Civil Society in Russia and China: A Comparative Approach. International Journal of Politics, Culture, and Society. 4: 323-347. 
Robertson G. B. 2009. Managing Society: Protest, Civil Society, and Regime in Putin's Russia. Slavic Review. 68 (3): 528-547.

Scott W. R., Davis G. F. 2015. Organizations and Organizing: Rational, Natural and Open Systems Perspectives. London: Routledge.

Yu Z. 2016. The Effects of Resources, Political Opportunities and Organisational Ecology on the Growth Trajectories of AIDS NGOs in China. VOLUNTAS: International Journal of Voluntary and Nonprofit Organizations. 27 (5): 2252-2273. 


\section{NEW TEXTS}

\section{Andrei Semenov, Vsevolod Bederson \\ Organizational Reactions of Russian NGOs to 2012 Legislative Changes}

SEMENOV, Andrei - Candidate of Science in Politics, Director, Center for Comparative History and Politics; Assistant Professor, Department of Political Science, Perm State University. Address: 15 Bukireva str., Perm 614990, Russian Federation.

\section{Email: andreysemenov@} comparativestudies.ru

\section{BEDERSON, Vsevolod -} Candidate of Science in Politics, Junior Fellow, Institute of Philosophy and Law of the Russian Academy of Sciences; Lecturer, Department of Political Science, Perm State University Address: 16 Sophia Kovalevskaya str., Yekaterinburg, 620990, Russian Federation.

Email: vsbederson@gmail.com

\section{Abstract}

In this article, we examine organizational reactions in the Russian third sector to adoption of the so-called "Foreign Agents" law in July 2012. Within the framework of organizational and resource dependence theories, we analyze state "licensing" policy in relation to civil society organizations and the tightening of regulation in the sector. We propose a typology of NGOs based on resource flows and rules of access, enabling a comparison of the organizational reactions of Russian NGOs to the new regulations. The study is grounded empirically in interviews with 19 representatives of NGOs in nine regions, along with data from internal documents, official statistics, and media reports. Our main argument is informed by the open systems theory of organizations, positing that growing state intervention in the third sector increasingly impacts NGOs' organizational features, regardless of type. The imposition of a listing of organizations "with foreign agent functions" has affected relations between the state, business, and the third sector, limiting access to resources for the latter. Measures like presidential grants and subsidies to compensate for resource shortfalls tend to be conditional, for example, on political loyalty. More generally, these environmental changes have hindered the capacity of third sector organizations to sustain professionalization. However, Russian NGOs have demonstrated considerable resilience in adapting to these changes through diffusion of organizational forms to minimize the costs of new legislation.

Keywords: civil society; NGOs; third sector; organizational theory; organizational adaptation; Russia.

\section{Acknowledgments}

This paper was prepared under the Department Development Partnership Program of the European University at Saint Petersburg. The authors express their gratitude to Eleonora Minaeva for her help with the interviews, and to the anonymous reviewers for their constructive comments on the early version of this paper.

\section{References}

Abou Assi K. (2013) Hands in the Pockets of Mercurial Donors: NGOs Response to Shifting Funding Priorities. Nonprofit and Voluntary Sector Quarterly, vol. 42, no 3, pp. 584-602.

Aldrich H. (2008) Organizations and Environments, Redwood City: Stanford University Press. 
Analiz zakona № 18-FZ “O vnesenii izmeneniy v nekotorye zakonodatel'nye akty Rossiyskoy Federatsii” [An Analysis of the Law No. 18-FL "On Amendments to Certain Legislative Acts of the Russian Federation"] (2006). Available at: http://www.strana-oz.ru/2005/6/analiz-zakona-no-18-fz-o-vnesenii-izmeneniy-vnekotorye-zakonodatelnye-akty-rossiyskoy-federacii (accessed 17 October 2016) (in Russian).

Astley W. G. (1985) The Two Ecologies: Population and Community Perspectives on Organizational Evolution. Administrative Science Quarterly, vol. 30, no 2, pp. 224-241.

Ataka na Fond [Attack on the Foundation] (2014) Available at: http://publicverdict.ru/topics/ataka/11999. html (accessed 17 October 2016) (in Russian).

Carroll G. R. (1985) Concentration and Specialization: Dynamics of Niche Width in Populations of Organizations. American Journal of Sociology, vol. 90, no 6, pp. 1262-1283.

Crotty J., Hall S. M., Ljubownikow S. (2014) Post-Soviet Civil Society Development in the Russian Federation: The Impact of the NGO law. Europe-Asia Studies, vol. 66, no 8, pp. 1253-1269.

Davlenie na grazhdanskoe obshhestvo v Rossii [Pressure on the Civil Society in Russia] (2016) Available at: http://publicverdict.ru/articles_images/freedom-of-assosiation_rus_nov212016.pdf(accessed 7 November 2016) (in Russian).

DiMaggio P. J., Powell W. W. (eds.) (1991) The New Institutionalism in Organizational Analysis, Chicago: University of Chicago Press.

Doklad Obshchestvennoy palaty RF o sostoyanii grazhdanskogo obshchestva v Rossiyskoy Federatsii [Report of the Public Chamber on the State of Civil Society in the Russian Federation] (2015) Available at: https:// www.oprf.ru/files/1_2016dok/doklad_OPRF_2015_19012016.pdf (accessed 7 November 2016) (in Russian).

Doklad Obshhestvennoy palaty RF o sostoyanii grazhdanskogo obshhestva v Rossiyskoy Federatsii [Report of the Public Chamber on the State of Civil Society in the Russian Federation] (2014) Available at: http:// pravorf.org/index.php/news/1388-o-doklade-obshhestvennoj-palaty-rf-o-sostoyanii-grazhdanskogo-obshhestva-v-rossijskoj-federaczii-za-2014-god (accessed 7 November 2016) (in Russian).

Dupuy K., Ron J., Prakash A. (2015) Who Survived? Ethiopia's Regulatory Crackdown on Foreign-Funded NGOs. Review of International Political Economy, vol. 22, no 2, pp. 419-456.

Ekonomicheskie posledstviya novogo zakonodatel'stva o nekommercheskikh organizatsiyakh. Analiticheskaya zapiska [The Economic Consequences of the New NGO Legislation"/ Analytic Report] (2007) Available at: http://www.socpolitika.ru/rus/ngo/documents/document812.shtml (accessed 18 March 2017) (in Russian).

Evans A. B., Henry L. A., Sundstrom L. M. (2006) Russian Civil Society: A Critical Assessment, Abingdon: M. E. Sharpe.

Ezhegodnyy doklad Ministerstva ekonomicheskogo razvitiya RF o deyatel'nosti i razvitii sotsial'no orientirovannykh NKO v 2015 [Annual Report of the Ministry of Economic Development of the Russian Federation on the Activities and the Development of Socially Oriented NGOs in 2015] (2016) Available at: http://nko. economy.gov.ru/PortalNews/Read/2934 (accessed 9 November 2016) (in Russian). 
Flikke G. (2016) Resurgent Authoritarianism: the Case of Russia's New NGO Legislation. Post-Soviet Affairs, vol. 32, no 2, pp. 103-131.

Gel'man V. (2015) Politika strakha: kak rossiyskiy rezhim protivostoit svoim protivnikam [The Politics of Fear: As the Russian Regime is Opposed to Their Opponents]. Kontrapunkt, no 1 (September), pp. 1-11. Available at: http://www.counter-point.org/64-2/ (accessed 7 October 2016) (in Russian).

Gilbert L. (2016) Crowding Out Civil Society: State Management of Social Organisations in Putin's Russia. Europe-Asia Studies, vol. 68, no 9, pp. 1553-1578.

Gordeeva E. (2016a) Kak stat' predatelem [How to Become a Traitor]. Meduza. Available at: https://meduza. io/feature/2016/04/20/v-borbe-s-vragami-postradali-druzya (accessed 7 October 2016) (in Russian).

Gordeeva E. (2016b) Prosto bol'she budet bednykh i bol'nykh [Just Longer be Poor and Sick]. Meduza. Available at: https://meduza.io/feature/2016/02/20/prosto-bolshe-budet-bednyh-i-bolnyh (accessed 7 October 2016) (in Russian).

Hannan M. T., Carroll G. R., Pólos L. (2003) The Organizational Niche. Sociological Theory, vol. 21, no 4, pp. 309-340.

Hannan M., Freeman D. (2013) Populyatsionnaya ekologiya organizatsiy [The Population Ecology of Organizations]. Journal of Economic Sociology = Ekonomicheskaya sotsiologiya, vol. 14, no 2, pp. 42-72. Available at: https://ecsoc.hse.ru/data/2013/04/05/1294839705/ecsoc_t14_n2.pdffpage=42 (accessed 7 October 2016) (in Russian).

Henry L. A. (2006) Shaping social activism in post-Soviet Russia: leadership, organizational diversity, and innovation. Post-Soviet Affairs, vol. 22, no 2, pp. 99-124.

Henry L. A. (2010) Red to Green. Environmental Activism in Post-Soviet Russia, Ithaca: Cornell University Press.

Hsu C. (2010) Beyond Civil Society: An Organizational Perspective on State-NGO Relations in the People's Republic of China. Journal of Civil Society, vol. 6, no 3, pp. 259-277.

Hydén G. (2006) Civil Society: What Next? Development Dialogue, vol. 47, no 1, pp. 183-201.

"Inostrannye agenty": mificheskie vragi i real'nye poteri rossiyskogo obshchestva ["Foreign Agents": Mythical Enemies and Real Losses of the Russian Society] (2015), Saint-Petersburg: Resursnyy pravozashhitnyy tsentr. Available at: http://philanthropy.ru/wp-content/uploads/2015/03/Inostranny-e-agenty-.pdf (accessed 9 November 2016) (in Russian).

Koval A. S., Ivolga A. M., Il'inykh I. I. (2014) Issledovanie informatsionnoy otkrytosti sistemy raspredeleniya gosudarstvennoy podderzhki NKO: 2011-2012 [The Study of Information Transparency of NGOs State Support Distribution System: 2011-2012] (ed. D. Y. Priimkov), Transparency International-R. Available at: http://nko67.ru/files/291/ngo_analisys_2014.pdf (accessed 7 November 2016) (in Russian).

Krasnopolskaya I., Skokova Y., Pape U. (2015) Government-Nonprofit Relations in Russia's Regions: An Exploratory Analysis. VOLUNTAS: International Journal of Voluntary and Nonprofit Organizations, vol. 26, no 6, pp. 2238-2266. 
Lang S. (2012) NGOs, Civil Society, and the Public Sphere, Cambridge: Cambridge University Press.

Lorch J., Bunk B. (2016) Using Civil Society as an Authoritarian Legitimation Strategy: Algeria and Mozambique in Comparative Perspective. Democratization, 23 November, pp. 1-19.

Mersiyanova I. V., Yakobson L. I. (2007) Negosudarstvennye nekommercheskie organizatsii: institutsional'naya sreda i effektivnost' deyatel'nosti [Nongovernmental Nonprofit Organisations: Institutional Environment and Performance], Moscow: HSE Publishing House (in Russian).

Meyer J. W., Rowan B. (2011) Institucitsnalizirovannye organizatsii: formal'naya struktura kak mif i tseremonial [Institutionalized Organizations: Formal Structure as Myth and Ceremony]. Journal of Economic Sociology $=$ Ekonomicheskaya sotsiologiya, vol. 12, no 1, pp. 43-67. Available at: https://ecsoc.hse.ru/ data/2011/12/08/1259551850/ecsoc_t12_n1.pdf\#page=43 (accessed 7 October 2016) (in Russian).

Minyust: v 2014 godu v Rossii zaregistrirovano pochti 100\% NKO, podavshikh zayavleniya (2015) [Ministry of Justice: in 2014 Russia Registered almost 100\% of NGOs that have Applied]. TASS. Available at: http:// minjust.ru/ru/press/news/minyust-v-2014-godu-v-rossii-zaregistrirovano-pochti-100-nko-podavshihzayavleniya (accessed 9 November 2016) (in Russian).

Muhametshina E. (2016) Minyust utochnil opredelenie politicheskoy deyatel'nosti NKO dlya zakona ob inostrannykh agentakh [The Ministry of Justice Clarified the Definition of Political Activity of NGOs to the Foreign Agents Law]. Vedomosti, no 4000 (25 January). Available at: http:/www.vedomosti.ru/politics/ articles/2016/01/25/625267-opredelenie-deyatelnosti-nko (accessed 9 November 2016) (in Russian).

O sostoyanii grazhdanskogo obshhestva v Rossiyskoy Federatsii za 2016 god. Annual Report [On the Public Chamber on the State of Civil Society in the Russian Federation in 2016. Annual Report] (2016), Moscow: Obshhestvennaya palata Rossiyskoy Federatsii (in Russian).

O vnesenii izmeneniy v nekotorye zakonodatel'nye akty Rossiyskoy Federatsii [On Amendments to Certain Legislative Acts of the Russian Federation]. Federal'nyy zakon [Federal Law] (2006) 10 January. (No 18-FZ).

Obsuzhdenie ponyatiya "politicheskaya deyatel'nost'”, razrabotannogo Minyustom Rossii v Sovete pri Prezidente Rossiyskoy Federatsii po razvitiyu grazhdanskogo obshchestva i pravam cheloveka (2015) [Discussion of the Concept of Political Activity of the Presidential Council on Civil Society and Human Rights]. Available at: http://president-sovet.ru/documents/read/432/ (accessed 9 November 2016) (in Russian).

PACE: Zakon ob NKO ne sootvetstvuet evropeyskim normam (2006) [PACE: NGO's Law does not Meet European Standards]. Available at: http://graniru.org/Politics/World/Europe/m.101102.html (accessed 9 November 2016) (in Russian).

Permskie NKO otkazalis' registrirovat'sya "inostrannymi agentami” (2013) [Perm NGO Refused to Register as Foreign Agents]. Available at: http://7x7-journal.ru/item/28253 (accessed 9 November 2016) (in Russian).

Pfeffer J., Salancik G. R. (2003) The External Control of Organizations: A Resource Dependence Perspective, Redwood City: Stanford University Press.

Portal grantov Obshhestvennoj palaty RF (2016) [Grants Portal of the Public Chamber of the Russian Federation]. Available at: https://grants.oprf.ru/ (accessed 9 November 2016) (in Russian). 
Powell W., Steinberg R. (2006) The Nonprofit Sector: A Research Handbook, New Haven: Yale University Press.

Radaev V. V. (2005) Populyatsionnaya ekologiya organizatsiy: kak voznikaet raznoobrazie organizatsionnykh form [Population Ecology of the Organization: How does a Variety of Organizational Forms Emerge]. Rossiyskiy zhurnal menedzhmenta, no 2, pp. 99-108 (in Russian).

Razvitie grazhdanskogo aktivizma vopreki: rossiyskie NKO posle zakonodatel'stva ob "inostrannykh" agentakh (2016) [The Development of Civic Activism Contrary: After the Russian Foreign Agent Law]. Klub yuristov tret'ego sektora. Available at: http://www.hro.org/files/2016_NLC_report\%20on\%20FA_Rus.pdf (accessed 9 November 2016) (in Russian).

Richter J., Hatch W. F. (2013) Organizing Civil Society in Russia and China: A Comparative Approach. International Journal of Politics, Culture, and Society, vol. 26, no 4, pp. 323-347.

Robertson G. B. (2009) Managing Society: Protest, Civil Society, and Regime in Putin's Russia. Slavic Review, vol. 68, no 3, pp. 528-547.

Roshal' L. (2006) Prinyatie zakona ob NKO yavlyaetsya politicheskoy oshibkoy [The Adoption of the NGO Law is a Political Mistake]. RBC.ru. Available at: http://www.rbc.ru/rbcfreenews/20060121144150.shtml (accessed 9 November 2016) (in Russian).

Rossiyane podderzhali usilenie kontrolya nad NPO (2006) [The Russians Supported the Strengthening of Control over NGOs]. Lenta.ru. Available at: https://lenta.ru/news/2006/03/16/ngo/ (accessed 9 November 2016) (in Russian).

Rossiyane podderzhivajut zhestkie mery v otnoshenii NKO (2013) [Russians Support Strict Measures against NGOs]. Izvestiya. 11 July. Available at: http://www.levada.ru/2013/07/11/rossiyane-podderzhivayut-zhestkie-mery-v-otnoshenii-nko/ (accessed 9 November 2016) (in Russian).

Scott W. R., Davis G. F. (2015) Organizations and Organizing: Rational, Natural and Open Systems Perspectives, London: Routledge.

Sozaev V. (2010) LGBT-dvizhenie v Rossii: portret v inter'ere [LGBT Movement: A Portrait in the Interior]. Gendernye issledovanija, no 21-22, pp. 90-126.

Stenogramma zasedanija Gosudarstvennoj Dumy FS RF 23 nojabrja 2006 g. (2006) [Transcript of the Meeting of the State Duma November 23, 2006]. Available at: https://docviewer.yandex. $\mathrm{ru} /$ ? url=https $\% 3 \mathrm{~A} \% 2 \mathrm{~F} \% 2 \mathrm{Fnkozakon} . \mathrm{ru} \% 2 \mathrm{Fwp}$-content $\% 2 \mathrm{Fuploads} \% 2 \mathrm{~F} 2005 \% 2 \mathrm{~F} 11 \% 2 \mathrm{~F} 63$. doc \&name $=63$. doc $\&$ lang $=$ ru\&c $=57$ ecd226a8de (accessed 9 November 2016) (in Russian).

Sungurov A. Ju. (2008) Struktury grazhdanskogo obshhestva i ih vzaimodejstvie s vlast'ju v Rossii [The Structures of Civil Society and Their Interaction with the Authorities in Russia]. V poiskah grazhdanskogo obshhestva [In Search of Civil Society], Veliky Novgorod: Yaroslav-the-Wise Novgorod State University, pp. 173-208 (in Russian).

Svedeniya reestra NKO, vypolnyayushhikh funktsii inostrannogo agenta (2017) [The List of NGO Perform the Functions of Foreign Agents]. Informatsionnyy portal Ministerstva yusticii Rossiyskoy Federatsii. Available at: http://unro.minjust.ru/NKOForeignAgent.aspx (accessed 9 November 2016) (in Russian). 
Tarasenko A., Kulmala M. (2015) Veteranskie organizatsii kak zainteresovannye gruppy: vozmozhnosti $i$ ogranicheniya klientelizma dlya zashchity sotsial'nykh prav v regionakh Rossii [Veterans' Organizations as Interested Groups: Opportunities and Constraints for the Protection of Social Rights in the Russian Regions]. Working paper M-42/15, Saint-Petersburg: European University at Saint-Petersburg (in Russian).

Tikhonovich L. (2013) Permskaya grazhdanskaya palata — ne inostrannyy agent [Perm Civic Chamber is not a Foreign Agent]. Filantrop: e-journal on philanthropy, 17 July. Available at: http://philanthropy.ru/ news/2013/07/17/12332/ (accessed 9 November 2016) (in Russian).

Tony Blair i shpionskiy kamen': proval britanskikh spetssluzhb v Moskve (2012) [Tony Blair and Spy Stone: the Failure of British Intelligence Agencies in Moscow]. Available at: http://www.rbc.ru/society/19/01/20 12/5703f1 fe9a7947ac81a6403c (accessed 9 November 2016) (in Russian).

Usacheva O. A. (2011) Jekologicheskij aktivizm v postsovetskoj Rossii i zapadnom mire (sravnitel'nyj analiz) [Environmental Activism in Post-Soviet Russia and the Western world (a comparative analysis)]. Sociologicheskie issledovanija, no 3, pp. 23-31 (in Russian).

Valitova L. A., Tambovtsev V. L. (2005) Organizatsionnaya ekologiya: vzglyad ekonomista [Organisational Ecology: Economic View]. Rossiyskiy zhurnal menedzhmenta, no 2, pp. 109-118 (in Russian).

Vandysheva E. A. (2014) Strategii NKO v svyazi s vvedeniem statusa "inostrannogo agenta" [NGO Strategies on the Introduction of the Foreign Agent Status]. Publichnaya politika - 2013, Saint-Petersburg: Norma, pp. 76-86 (in Russian).

Yanitskiy O. N. (1995). Evolyutsiya ekologicheskogo dvizheniya v sovremennoy Rossii [The Evolution of the Environmental Movement in Contemporary Russia]. Sotsiologicheskie issledovaniya, no 8, pp. 15-25 (in Russian).

Yu Z. (2016) The Effects of Resources, Political Opportunities and Organisational Ecology on the Growth Trajectories of AIDS NGOs in China. VOLUNTAS: International Journal of Voluntary and Nonprofit Organizations, vol. 27, no 5, pp. 2252-2273.

Zakon, ogranichivayushchiy deyatel'nost' NKO, vstupit v silu v seredine aprelya [The Law Restricts the Activities of NGOs will Take Effect in Mid-April] (2006) Available at: http://bellona.ru/2006/01/19/zakonogranichivayushhij-deyatelnost-n/ (accessed 9 November 2016) (in Russian).

Received: December 12, 2016.

Citation: Semenov A., Bederson V. (2017) Organizatsionnye reaktsii rossiyskikh NKO na zakonodatel'nye izmeneniya $2012 \mathrm{~g}$. [Organizational Reactions of Russian NGOs to 2012 Legislative Changes]. Journal of Economic Sociology = Ekonomicheskaya sotsiologiya, vol. 18, no 2, pp. 11-40. Available at https://ecsoc.hse. ru/2017-18-2.html (in Russian). 


\section{РАСШИРЕНИЕ ГРАНИЦ}

\section{Э. Б. Аткинсон}

\section{Что такое «неравенство», и можем ли мы его преодолеть?}

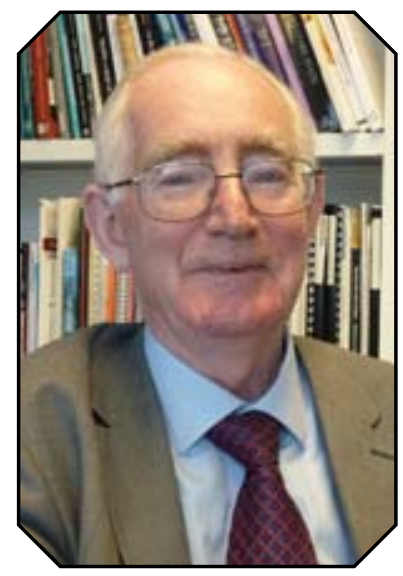

АТКИНСОН Энтони Б., сэр (1944-2017) известный экономист, занимавшийся изучением вопросов социальной справедливости и разработкой мер государственной политики. Служил профрессором в Лондонской школе экономики и научным сотрудником в Нафффилдколледже Оксфордского университета.

Публикуется с разрешения Издательства Института им. Е. Т. Гайдара.
В данной книге автор пытается решить задачу по уменьшению неравенства в распределении доходов, которое в настоящее время приобрело невероятные масштабы. Сэр Э. Аткинсон предлагает взглянуть на экономическое неравенство с нового ракурса, при этом все свои рассуждения он подкрепляет историческими данными, охватывающими столетний период эволючии современных обществ.

Книга состоит из трёх частей. В первой части автор формулирует исследовательскую проблему, задаваясь следующими вопросами: что понимается под неравенством и какова сегодня его степень? Бывали ли в истории периоды снижения неравенства? Как трактует причины неравенства экономическая теория? Вторая часть посвящена конкретным политическим и экономическим мерам, которые автор предлагает реализовать для уменьшения неравенства. В третьей части приводится оценка реалистичности сформулированных во второй части предложений, а также анализируются все «за» и «против», которые могут возникнуть в ходе их обсуждения и внедрения.

Журнал «Экономическая сочиология» публикует первую главу первой части книги — «Предварительные установки» («Setting the Scenе»), в которой автор вводит в курс дела читателей, рассуждая о неравенстве и его масштабах. Аткинсон демонстрирует, что само понятие «неравенство» имеет множество значений, $u$, прежде, чем разбираться в его причинах, необходимо решить вопросы, касающиеся его основных параметров.

Ключевые слова: экономическое неравенство; распределение доходов; социальная справедливость; бедность; потребление; домохозяйство.

\section{Глава 1}

\section{Предварительные установки}

Эта книга посвящена способам уменьшения неравенства, и с самого начала я должен пояснить, какие именно задачи под этим подразумеваются. Начнём с устранения одного из возможных недоразумений. Я не стремлюсь к отмене всех различий в результатах экономической деятельности. Не жажду полного равенства. Более того, известные различия в уровне материального достатка могут быть вполне оправданными. Цель, скорее, состоит в

1 Часть первая «Диагноз». - Примеч. ред. 
Источник: Аткинсон Э. Б. (готовится к изданию). Что такое «неравенство», иможем ли мы его преодолеть? М.: Институт им. Е. Т. Гайдара. Перев. с англ.: Atkinson A. B. 2015. Inequality: What can be Done? Cambridge, MA; London: Harvard University Press. сокращении нынешнего уровня неравенства, который представляется чрезмерным. Я намеренно высказался лишь о направлении этого движения, а не о конечном пункте назначения. Соглашаясь, что нынешний уровень неравенства является нестабильным или недопустимым, читатели могут расходиться во мнениях относительно того, какой именно уровень неравенства следует считать приемлемым.

В этой главе мы рассмотрим причины, по которым нас беспокоит проблема неравенства, а также её место в ряду базовых социальных ценностей. Затем мы взглянем на эмпирические данные. Какова степень неравенства наших сообществ? Насколько выросло это неравенство? Составив о нём общее представление, мы перейдём к более глубокому исследованию. Какие данные включены в статистику и чего в ней не хватает? Какое место в системе распределения доходов принадлежит тем или иным социальным группам?

\section{Неравенство возможностей и неравенство результатов}

При упоминании о «неравенстве» многие представляют себе борьбу за «равные возможности». Такое выражение часто встречается в политических речах, партийных манифестах и предвыборной риторике. Это мощный лозунг, укоренённый глубоко в истории. В своём классическом эссе под названием «Equality» («Равенство») Ричард Тоуни утверждал, что каждому должно быть «в равной степени позволено извлекать максимум выгоды из тех достоинств, коими он обладает» [Tawney 1961: 46-47]. Вслед за Джоном Рёмером, в экономической литературе последнего времени детерминанты экономического успеха принято разделять на две категории. Первая - «обстоятельства», не зависящие от личного участия (например, семейное окружение), вторая - «усилия», ответственность за которые несёт сам человек. Равенство возможностей достигается тогда, когда переменные первого типа, то есть обстоятельства, не играют в достижении результата никакой роли. Если некто усердно учился в школе, успешно сдал экзамены и поступил в медицинский институт, то хотя бы отчасти (но необязательно целиком) его высокая зарплата врача объясняется личными усилиями. Если же, напротив, поступление в вуз было обеспечено влиянием родителей (например, в том случае, если предпочтение при наборе отдаётся детям выпускников того же института), то имеет место неравенство возможностей [Roemer 1998].

Концепция «равенства возможностей» весьма привлекательна. Но значит ли это, что никакой роли не играет «неравенство результатов»? На мой взгляд, ответ на этот вопрос отрицательный. Даже для тех, кто начинает с рассуждений о «равных условиях игры», неравенство её результатов сохраняет актуальность. Чтобы понять причину, нам нужно для начала разграничить две концепции. Неравенство возможностей, по существу, является понятием ex ante ${ }^{2}$ (каждый должен иметь равные стартовые возможности), тогда как основная часть усилий по перераспределению даёт результаты ex post ${ }^{3}$. Тот, кто отрицает важность неравенства результатов, не считает законной

2 Ex ante (лат.) - до наступления факта. - Примеч. ред.

3 Ex post (лат.) - после свершившегося факта. - Примеч. ред. 
озабоченность понятием ex post и полагает, что, установив равные правила для жизненной гонки, мы не должны вмешиваться в её результаты. Мне это представляется ошибочным по трём причинам.

Во-первых, большинство людей считают недопустимым игнорировать то, что происходит на дорожке после стартового выстрела. Бывает, что людям, не жалевшим усилий, просто не везёт. Представим, что волею судеб некие странники лишились всех средств. В любом гуманном обществе таким людям окажут помощь. Мало того, многие считают, что помощь следует предложить им без расспросов о причинах столь бедственного положения. Как полагают экономисты Рави Канбур и Адам Вагстафф, было бы аморальным «отказать голодному в тарелке супа из-за того, что в очереди за бесплатным обедом он оказался не по воле обстоятельств, а по собственной вине» [Kanbur, Wagstaff 2014: 5]. Итак, первая причина, по которой результаты жизненной гонки имеют значение: мы не можем игнорировать людей, для которых этот результат оказался плачевным, даже если принцип равенства возможностей ex ante полностью соблюдался.

Однако важность результатов «гонки» имеет более глубокий смысл, позволяющий обозначить вторую причину значимости их неравенства. Для этого необходимо разграничить конкурентное и неконкурентное равенство возможностей. Это последнее гарантирует всем людям равные шансы осуществлять их независимые жизненные проекты. Чтобы продолжить «спортивную» аналогию, предположим, что каждый имеет право научиться плавать. И наоборот, конкурентное равенство возможностей означает лишь, что все мы имеем равные шансы на участие в «гонке» - соревнованиях по плаванию, — где присуждаются неравные призы. В этом, более типичном случае участники получают неравные награды ex post, и здесь обнаруживается неравенство результатов. Именно это - крайне неравномерное распределение призов заставляет требовать, чтобы гонка велась по справедливым правилам. К тому же «призы» в значительной мере социально обусловлены. Что именно получит победитель - лавровый венок или 3 млн дол. (главная награда в Открытом турнире США по теннису 2014 г.), - зависит от наших экономических и социальных норм. Определение структуры социального «приза» и является главной задачей настоящей книги.

Наконец, есть и третья причина беспокоиться о неравенстве результатов: они прямо влияют на равенство возможностей для следующего поколения. Сегодняшние результаты ex post определяют завтрашние условия гонки ex ante: бенефициары неравенства результатов передают несправедливое преимущество своим детям. По мере того как всё более неравномерным становится распределение доходов и богатства, усиливается и наша озабоченность неравенством возможностей и ограничением социальной мобильности. Это объясняется тем, что влияние семейного окружения на результат - например, карьеры - зависит как от силы взаимодействия между окружением и результатом, так и от степени неравенства семейных окружений. Неравенство результатов в жизни нынешнего поколения - источник незаслуженных преимуществ для следующего поколения. Если нас волнует завтрашнее равенство возможностей, то следует подумать о сегодняшнем неравенстве результатов.

\section{Причины озабоченности неравенством - инструментальные и сущностные}

Даже для тех, чьей конечной целью является равенство возможностей, сокращение неравенства результатов сохраняет актуальность, ибо служит средством достижения этой цели. На другие инструментальные причины, по которым нас должно беспокоить неравенство результатов, указывают такие популярные авторы, как Джозеф Стиглиц в книге «The Price of Inequality» («Цена неравенства») [Stiglitz 2012], а также Кейт Пикетт и Ричард Уилкинсон в книге «The Spirit Level» («Ступень духа») [Pickett, Wilkinson 2010]. Они утверждают, что нам следует уменьшить неравенство результатов, поскольку оно негативно влияет на современное общество. В увеличении неравенства авторы находят причину целого ряда общественных проблем, таких как недостаток социальной сплочённости, рост 
преступности, ухудшение здоровья населения, подростковая беременность, ожирение и т. п. Политологи выявили двустороннюю связь между неравенством доходов и ролью богатства в определении итогов демократических выборов - связь, характеризующуюся «смычкой идеологии и денежного мешка» ${ }^{4}$. Экономисты напрямую связывают ухудшение хозяйственных показателей с увеличением неравенства. Кристин Лагард, обращаясь в 2012 г. к участникам ежегодного совещания Международного валютного фонда и Всемирного банка, обозначила «третью проблему: неравенство - и качество экономического роста в мире будущего». И добавила: «Недавнее исследование Международного валютного фонда (МВФ) показывает, что уменьшение неравенства ведёт к укреплению макроэкономической стабильности и устойчивому росту». Масштаб последующих выгод от сокращения неравенства заслуживает подробного обсуждения, и к рассмотрению связи между неравенством и хозяйственной эффективностью я вернусь в главе 9.

Впрочем, аргументы в пользу сокращения неравенства не ограничиваются констатацией его отрицательных последствий, описанных выше. Есть сущностные основания полагать, что нынешний уровень неравенства чрезмерен. Эти основания можно сформулировать в понятиях более общей теории справедливости. Для экономистов, писавших об этих вопросах сто лет назад, было естественно мыслить в утилитарных категориях. Оценивая индивидуальное благосостояние с точки зрения количества благ, доступных каждому человеку, эти экономисты утверждали, что избыточное неравенство уменьшает сумму общего блага (всеобщей пользы), поскольку для более обеспеченных членов общества ценность (value) каждой дополнительной единицы дохода (или, говоря обобщённо, экономических ресурсов) оказывается меньшей, чем для менее обеспеченных. Как писал Хью Далтон, британский экономист и канцлер Казначейства в послевоенном правительстве лейбористов, если взять у богатого 1 фунт стерлингов и отдать его бедному, то это, при прочих равных условиях, приведёт к уменьшению степени неравенства и увеличению суммы жизненных благ для общества в целом [Dalton 1920a] .

Утилитаризм часто критикуют, не в последнюю очередь за внимание исключительно к сумме индивидуальных благ и, как отмечает Амартия Сен, за «полнейшее равнодушие к распределению этой суммы между конкретными людьми, из-за чего такой подход в качестве метода измерения или оценки неравенства становится особенно неподходящим» [Sen 1973: 16]. Именно поэтому при измерении неравенства применяется методика «взвешивания» долей распределяемых благ, когда нуждам менее обеспеченных людей присваивается больший удельный вес. Такое «взвешивание» учитывает наши социальные ценности, касающиеся перераспределения, и составляет сущностную основу нашей озабоченности проблемой неравенства. Вопрос о том, какими должны быть эти удельные веса, остаётся дискуссионным, как в «эксперименте с дырявым ведром» показал экономист Артур Оукен. Этот учёный задался вопросом, что случится, если в процессе трансферта часть суммы в 1 фунт стерлингов (о которой писал Далтон) будет потеряна. Из полученного ответа Оукен вывел величину, на которую необходимо увеличить удельный вес, присваиваемый доходу реципиента (по сравнению с доходом донора), чтобы данный трансферт был экономически оправдан. Если при трансферте «из ведра вытечет» половина суммы, то придётся присвоить доходу получателя вдвое больший по сравнению с доходом донора удельный вес. Те, кто увеличивает удельный вес менее обеспеченных реципиентов, склонен к радикальному перераспределению; они готовы двигаться в сторону уменьшения неравенства. В предельном варианте максимальный вес присваивается беднейшим индивидуумам - позиция, которую часто ассоциируют с «Теорией справедливости» Джона Ролза, хотя эта последняя не сводится к описанному предельному варианту [Rawls 1971].

4 Данная фраза - подзаголовок кн.: [McCarty, Poole, Rosenthal 2006]. - Зд. и далее примеч. автора.

5 В связи с празднованием своего 125-летия Королевское экономическое общество выбрало работу Х. Далтона как одну из самых выдающихся статей, опубликованных в издании «Economic Journal» за указанный период [Dalton 1920; Atkinson, Brandolini 2015]. 
Позиция Джона Ролза, отдающего предпочтение наименее благополучным индивидуумам, может показаться довольно радикальной. Однако она недалека от взглядов политиков, выступающих за снижение подоходного налога на том основании, что это стимулирует экономическую активность и, следовательно, ведёт к увеличению прибыли, которую можно будет направить на повышение доходов беднейших из нас. Как видно из его аргументации, цели Джона Ролза, в сущности, не содержат ничего эгалитарного. Максимизация доли наименее благополучных граждан способна привести к весьма неравномерному распределению благ. В этом смысле много радикальнее Джона Ролза был Платон, считавший, что никто не должен быть более чем в четыре раза богаче беднейшего члена общества [Plato 1960: 127] (цит. по: [Fair 1971: 552]). Согласно эгалитарной позиции Платона, неравенство значимо ещё и в смысле дистанции между богатыми и бедными, так что повод для действий может возникать даже там, где бедные ничего не выигрывают. «Теория справедливости» Ролза вызвала в среде философов, погруженных в вопросы этики, публичную дискуссию о природе социальной справедливости. Особое значение приобретает трактовка Ролзом принципов справедливости в смысле доступности базовых благ (primary goods). Эти блага — «то, чего прежде всего желает всякий разумный человек» — описываются в таких широких категориях, как «права, возможности, полномочия, доходы и богатство» [Rawls 1971: 92]. Как полагает Амартия Сен, по этому пути мы идём дальше утилитаризма, но не доходим до анализа «широкого спектра вариантов, позволяющих превращать базовые блага в условия хорошей жизни» [Sen 2009: 66]. Сен предлагает нам перейти от «базовых благ» к «потенциальным возможностям» (capabilities), определяя социальную справедливость как наличие шансов, предоставляемых людям в соответствии с их жизненным предназначением (functioning).

От подхода Ролза этот подход с точки зрения потенциальных возможностей отличается в двух аспектах. Во-первых, это интерес к тому, как те или иные блага помогают людям в конкретных обстоятельствах (так, в нём учитывается, что на проезд до работы инвалиды порой тратят больше денег, чем здоровые люди). Такой подход привлекает наше внимание не только к достигнутым результатам, но и к диапазону возможностей, который Сен считает одним из важных элементов личной свободы - отсюда и название его книги: «Development as Freedom» («Развитие как свобода») [Sen 1999]. В практическом плане подход с точки зрения потенциальных возможностей расширяет диапазон анализируемых социально-экономических показателей. В частности, 25 лет назад под его влиянием Махбуб уль-Хак разработал индекс человеческого развития (Human Development Index). Индекс ранжирует страны по степени их развития, учитывая такие показатели, как уровень образования, ожидаемая продолжительность жизни и доход на душу населения ${ }^{6}$. В сегодняшнем контексте подход с точки зрения потенциальных возможностей возвращает нас к инструментальным причинам озабоченности неравным доступом к экономическим ресурсам, теперь уже в рамках согласованного набора принципов справедливости В этих рамках размер дохода служит лишь одним из критериев, и разницу в доходах следует интерпретировать в свете различающихся обстоятельств и связанных с ними возможностей. Тем не менее нам не уйти от той истины, что одним из важнейших факторов несправедливости остаётся доступ к экономическим ресурсам. Именно это заставляет меня сосредоточиться здесь на экономическом измерении неравенства. Зададимся вопросом: что могут сказать о неравенстве экономисты?

\section{Экономисты и неравенство доходов}

Около двух десятков лет назад я, как председатель Королевского экономического общества (Royal Economic Society), обратился к его членам с текстом, озаглавленным: «Вернуть былое значение понятию “распределение доходов”» [Atkinson 1997]. Название подчёркивало тот факт, что в экономиче-

6 См. сайт Программы развития ООН (ПРООН) - URL: http://hdr. undp.org/en/content/human-development-index-hdi

7 Подробнее о подходе с точки зрения потенциальных возможностей см. на сайте «Ассоциации человеческого развития и возможностей» (Human Development and Capability Association) — URL: https://hd-ca.org/ 
ской науке проблематика неравенства доходов оказалась на периферии. На протяжении большей части $\mathrm{XX}$ века эта тема игнорировалась, тогда как, я полагаю, в изучении экономики она должна занимать центральное место. Я начал изложение со ссылки на Далтона, выражавшего такую же озабоченность ещё в начале XX века. В частности, он рассказывал, что в студенческие годы его особо интересовал вопрос распределения доходов. Постепенно он заметил, что большинство теорий распределения почти целиком посвящены вопросам распределения ресурсов между факторами производства. Далее он пишет: «Распределение материальных благ между людьми - проблема, представляющая более очевидный и непосредственный интерес, - либо вообще исключалась из учебников, либо освещалась предельно кратко. Можно было заключить, что она не вызывает вопросов, на которые нельзя было бы ответить с помощью обобщений, касающихся факторов производства, или кропотливых статистических исследований, на что преподаватели экономической теории не претендовали, оставляя их менее значительным персонажам» [Dalton 1920b: vii].

То же справедливо и для 1990-х гг., когда я предпринял анализ литературы по экономической теории. В своём очерке истории экономической мысли, касающейся проблем распределения доходов, Агнар Сандмо отмечает: «В современной теории общего равновесия связям между распределением ресурсов и распределением доходов особого внимания не уделяется; автор солидного изложения экономической теории лауреат Нобелевской премии Жерар Дебрё термину “распределение” даже не отводит места в своём индексе» [Sandmo 2015: 22]. Кроме того, Сандмо отметит, что экономическая теория начала «преодолевать пренебрежение к проблематике распределения доходов. Однако это пренебрежение до сих пор проявляется в том, какое место данной тематике уделяется во вводных курсах и учебниках по микроэкономической теории» [Sandmo 2015: 60-61] (см. также: [Debreu 1959]). Обзор наиболее популярных современных учебников показывает, что их структура остаётся во многом той же, что и в прошлом; обсуждение вопросов неравенства отделено от основных глав, посвящённых производству и макроэкономике. Например, в книге гарвардского профессора Грэга Мэнкью «Principles of Microeconomics» («Принципы микроэкономики») имеется отличная глава — «Неравенство доходов и бедность» («Income Inequality and Poverty»), но она оторвана от предшествующих глав (как и от одноименного учебника для практических занятий «Принципы микроэкономики»). Возможно, ещё более примечателен тот факт, что при сведении текста к сжатым «Основам экономики» («Essentials of Economics») глава о неравенстве «не попала в формат», каковой - по мысли автора — призван «выделить материал, представляющий особый интерес для лиц, изучающих экономику» [Mankiw 2007; 2014]. По-видимому, тема экономического неравенства этим критериям не отвечает ${ }^{8}$.

Смысл сказанного в том, что вопросы распределения не представляют для экономистов значительного интереса. Мало того, ряд экономистов полагают, что экономическая теория вообще не должна интересоваться вопросами неравенства. Это мнение с особой убеждённостью высказал нобелевский лауреат Роберт Лукас из Чикагского университета: «Из тенденций, вредных для здравой экономической теории, самой обманчивой и, на мой взгляд, самой пагубной является чрезмерное внимание к вопросам распределения <..> Возможность улучшить жизнь бедняков различными способами распределения уже имеющейся продукции - ничто по сравнению с представляющимся безграничным потенциалом увеличения объёмов производства» [Lucas 2003: 20].

Лукас прав, подчёркивая большой вклад экономического роста в улучшение жизни многочисленных бедняков во всём мире. Если в будущем рост экономики примет устойчивые формы (именно «если»), то для человечества откроются перспективы сокращения международного неравенства и облегчения уча-

8 В новых учебных материалах, создаваемых в рамках проекта INET CORE, то есть открытого онлайн-курса по экономической теории и экономике, особое внимание уделяется экономическому неравенству. На вопрос «что такое экономическая наука?» вторым по порядку ответом (из четырёх возможных) указан следующий: «Это наука, объясняющая причины богатства и бедности народов и государств», URL: http:/core-econ.org/about/. 
сти малообеспеченных граждан в каждой из стран. Однако я не согласен с Лукасом в двух отношениях. Во-первых, распределение и перераспределение всей существующей массы доходов не может не быть важным вопросом для конкретного человека. Степень имущественных различий оказывает глубокое воздействие на характер нашего общества. Нам небезразличен тот факт, что одни могут позволить себе космическое путешествие, тогда как другие стоят в очереди за льготными продовольственными наборами. Представляется, что общество, где никто не сможет частным образом путешествовать в космосе, но каждый способен приобрести продукты в обычном магазине, окажется более сплочённым и проникнутым чувством общности интересов. Во-вторых, от характера распределения зависит совокупный объём производства. Чтобы понять, как работает экономика, необходимо понять, как распределяются доходы. Недавний экономический кризис показал, что недостаточно следить за макроэкономическими индикаторами. Вопросами первостепенной важности являются экономические различия между людьми. Критикуя модели, доминирующие в современной макроэкономике, нобелевский лауреат Роберт Солоу из Массачусетского технологического института отмечает: «Сущностью современной экономики является её гетерогенность. В реальной жизни нам отнюдь небезразличны взаимные отношения менеджеров и акционеров, кредиторов и заёмщиков, рабочих и работодателей, предпринимателей и венчурных капиталистов... Список можно продолжить $<\ldots .>$. Мы твёрдо знаем, что разные экономические агенты имеют различные (а иногда и противоположные) цели, разную информацию, разные возможности её обработки, разные ожидания и разные представления о том, как работает экономика. Весь этот разнообразный пейзаж доминирующие ныне модели исключают» [Solow 2003]. Вопросы материального распределения и разницы экономических результатов для отдельных лиц - не единственная тема экономики (предполагать такое было бы безосновательным), но они являются её неотъемлемой частью.

В этой книге, где вопросы распределения занимают центральное место, я стремлюсь показать, как они связаны с нашим пониманием функционирования экономики. Однако для начала мы должны проанализировать результаты кропотливых статистических исследований, в которых участвовали автор и его коллеги. Насколько неравными являются наши сообщества? Как сильно возросло материальное неравенство в последние десятилетия?

\section{Первый взәляд на реальное положение дел}

Общая картина экономического неравенства в Великобритании и США за последние сто лет представлена на рисунках 1.1 (для США) и 1.2 (для Великобритании).

Начнём с эволюции, которую во времени претерпел феномен общего неравенства в распределении доходов домашних хозяйств. Более подробное определение дохода домохозяйств даётся в следующем разделе; пока же мы можем принять за него (в случае США) величину личного дохода, которую налогоплательщик указывает в своей налоговой декларации. Мерой неравенства служит коэффициент Джини - сводный индекс неравенства в диапазоне 0-100\%, популяризованный итальянским статистиком Коррадо Джини 9 . Подразумевается, что при использовании коэффициента Джини индивидуальным долям распределяемых доходов, как это обсуждалось ранее, присуждаются удельные веса. Однако это может быть неочевидным для бесчисленных исследователей, применяющих этот индекс. В сущности, применяя коэффициент Джини, они «по умолчанию» присваивают каждому дополнительному фунту стерлингов, попадающему в карман бедняка, втрое больший вес, чем дополнительному

9 Хотя коэффициент носит его имя, сам К. Джини великодушно признавал, что базовую статистику - среднюю разницу (mean difference) - примерно тридцатью годами раньше предложили два немецких учёных - Карл Кристофер фон Андре (Carl Christopher von Andrae) и Фридрих Роберт Гельмерт (Friedrich Robert Helmert) [Gini 1912: 52n]. Тот, кто интересуется историей статистики, должен помнить, что профессор Гельмерт одним из первых пришёл к пониманию хи-квадратного распределения (the chi-squared distribution). 
фунту стерлингов, появляющемуся в кармане богача ${ }^{10}$. В контексте эксперимента с дырявым ведром можно представить себе человека, теряющего две трети от суммы некоего трансферта, но продолжающего считать эту сделку для себя выгодной. Здесь я оперирую коэффициентом Джини, поскольку (1) он широко используется в литературе и (2) в таком виде представлены имеющиеся статистические данные. Тем не менее следует помнить, что (1) этот индекс приводит всё распределение к одной цифре и (2) существует множество разных способов такого преобразования ${ }^{11}$.

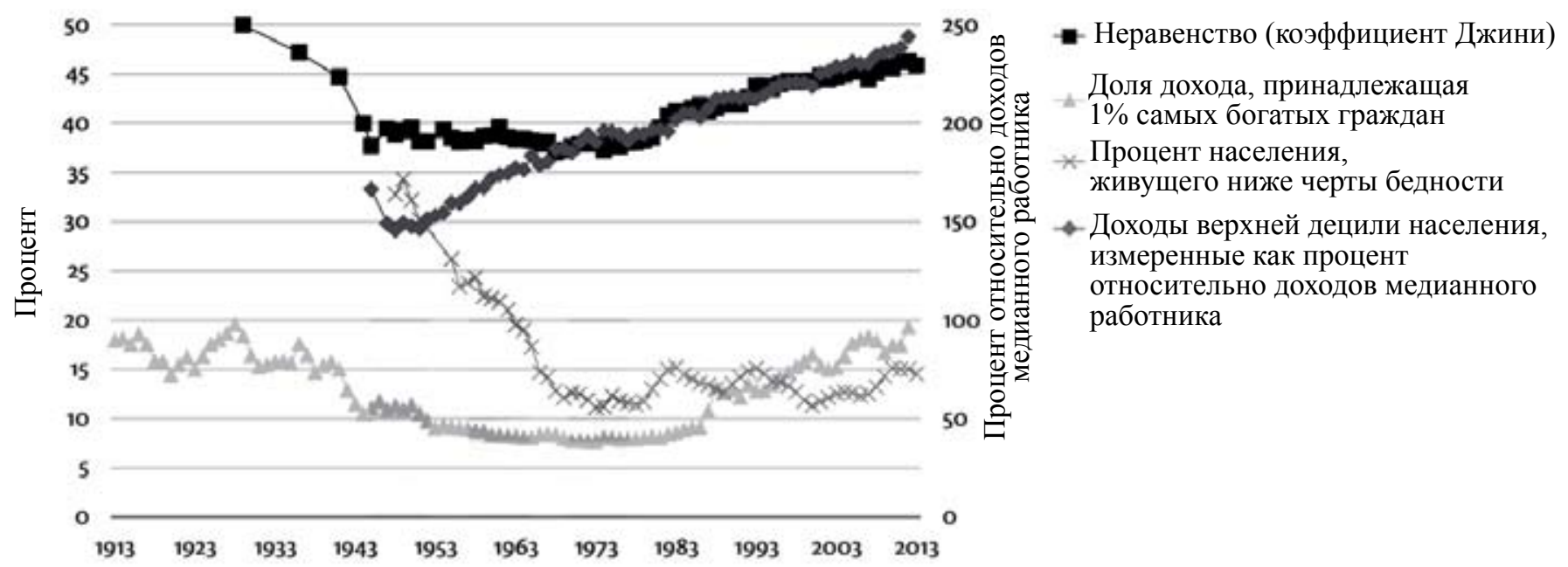

Источники: Основной источник: [Atkinson, Moreli 2014]. Данные по США взяты из приведённых ниже источников. Вопросы неравенства в целом: [U.S. Bureau of the Census 2014: Table A-3, "Selected Measures of Equivalence-Adjusted Income Dispersion"], где сделано предположение, что половина отмеченных изменений в 1992-1993 гг. была связана с переменой метода, когда к значениям, отмеченным (ретроспективно) в 1967-1992 гг., были добавлены 1,15 процентного пункта. Этот цифровой ряд продолжен назад во времени, и данные 1967 г. привязаны к серии, начатой с 1944 г. и представленной в публикации: [Budd 1970]. Доля дохода богатейшего 1\% населения: [Piketty, Saez 2003]; обновлённые данные с сайта Саеза см. URL: http://eml.berkeley. edu/ saez/. Уровень бедности: до 1959 г. — из работы: [Fisher 1970: Таble 6]. Данные за период с 1959 г. - с веб-сайта Бюро переписи США, Historical Poverty Tables, Table 2, а также из публикаций Бюро переписи США [U.S. Bureau of the Census 2014: Table B1]. Личные доходы: основой этих данных является Current Population Survey (CPS) from the OECD iLibrary; самые свежие данные доступны на сайте URL: http://www.oecd-ilibrary.org/employment/data/oecdemployment-and-labour-market-statistics lfs-data-en Эти данные привязаны в 1973 г. к оценкам: [Karoly 1994: Table 2B.2]; a в 1963 г. - к оценкам: [Atkinson 2008: Täble T.10]. Этот последний источник содержит информацию, отличную от данных из других источников в том, что касается состава выборки и сроков опроса.

Примечание: Общее неравенство (на графике помеченное чёрными квадратами) измеряется коэффициентом Джини, в основе которого лежит валовой доход домохозяйств, скорректированный на величину этих последних. Треугольниками помечена доля совокупного валового дохода (без учёта доходов от прироста капитала), принадлежащая $1 \%$ самых богатых граждан. Крестами отображён процент населения, живущего ниже официальной черты бедности. Ромбами (которым соответствует правая шкала) показаны доходы верхней децили населения (10\% богатейших граждан) относительно доходов занятого на полной ставке медианного работника (находящегося посередине кривой распределения доходов).

Рис. 1.1. Неравенство в США, 1913-2013 гг.

График общего неравенства (см. рис. 1.1) даёт долгосрочную перспективу, показывающую, что распределение доходов в США со временем претерпело кардинальные изменения. В середине XX века создалось впечатление, что доходы в этой стране распределяются всё более равномерно. В 1966 г. Герман Миллер (Herman Miller) из Бюро переписи населения США заявил: «Этой точки зрения придерживаются видные экономисты, и её же разделяют влиятельные писатели и редакторы» [Miller 1966: 2]. В подтверждение он сослался на мнение журнала «Fortune» по поводу революиии в распределении,

10 Весовые значения выражены формулой $2(1 F)$, где $F-$ место (ранг) человека в иерархии доходов; см.: [Аtkinson, Brandolini 2010].

11 О введении критериев экономического неравенства см.: [Jenkins, Kerm 2009]. 
«которая произошла без отсечения голов и захвата железнодорожных вокзалов» [Miller 1966: 2] ${ }^{12}$. По сравнению с пиком, достигнутым в 1929 г., коэффициент Джини снизился примерно на 10 процентных пунктов. С окончания Второй мировой войны до конца 1970-х гг. уровень общего неравенства в США претерпел мало изменений. В связи с этим американский экономист Генри Аарон отпустил известную шутку: «Отслеживать статистику распределения доходов в США - всё равно что наблюдать за тем, как растёт трава». Позднее, в 1980-е гг., «трава» резко поднялась. В США случился «Поворот к неравенству» (Inequality Turn). В 1977-1992 гг. коэффициент Джини вырос примерно на 4,5 процентного пункта; с 1992 г. он увеличился ещё на три пункта. Общее состояние неравенства не вернулось на уровень, достигнутый в Эпоху джаза ${ }^{13}$, но сегодня оно более чем на полпути к этой отметке.

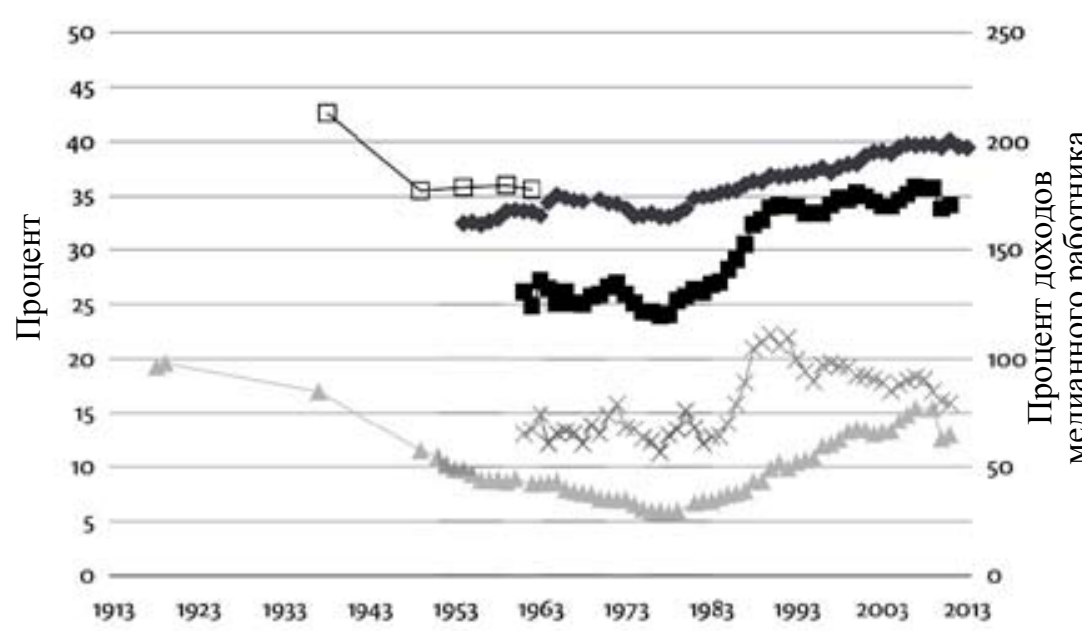

Неравенство (коэффициент Джини, более поздние временные ряды)

— Неравенство (коэффициент Джини, более ранние временные ряды)

Доля дохода, принадлежащая $1 \%$ самых богатых граждан

- Процент населения, живущего ниже черты бедности

- Доходы верхней децили населения, измеренные как процент относительно доходов медианного работника

Источники: Основной источник: [Atkinson, Morelli 2014]. Данные по Великобритании взяты из приведённых ниже источников. Вопросы неравенства в целом: коэффициент Джини для выровненного (согласно модифицированной шкале ОЭСР) располагаемого дохода домохозяйств всех жителей Соединённого Королевства (до 2001-2002 г. — только Великобритании), находятся на сайте аналитического центра Institute for Fiscal Studies: URL: http://www.ifs.org.uk/. Данные за 1961-1992 гг. (финансовый 1993-1994 г.) взяты из «Обзора семейных расходов» («Family Expenditure Survey») и «Обзора семейных ресурсов» («Family Resources Survey»). Источником более ранних значений коэффициента Джини («Blue Book Series») является: [Atkinson, Micklewright 1992: Table BI1]; Источник цифр за 1938 г.: [The Royal Commission on the Distribution of Income and Wealth... 1979: 23]. Доля дохода богатейшего 1\% населения: World Top Incomes Database (WTID), URL: http://topin comes.g-mond.parisschoolofeconomics.eu/. Данные об уровне бедности взяты с сайта Института финансовых исследований (предыдущие серии расходов на жильё), как описано выше. Индивидуальные доходы: данные Annual Survey of Hours and Earnings (касающиеся всех совершеннолетних работников, занятых полный рабочий день, зарплата которых за период обследования не зависела от их отсутствия - по любым причинам - на рабочем месте). Эти данные привязаны к предыдущим данным (чтобы учесть изменения в методологии, осуществлённые в 2006 и 2004 гг.) и вновь (в 2000 г.) привязаны к предыдущим данным NES (New Earnings Survey), взятым из публикации: [Atkinson 2008: Table S.8]. Серии продлены назад во времени до 1968 г. (начало публикации итогов NES) и там привязаны к данным о подоходном налоге (доходы, включённые в «Schedule E») из того же источника, таблица S.7.

Примечание: Общее неравенство, измеряемое коэффициентом Джини, помечено на графике квадратами. В ранних цифровых рядах (белые квадраты) в основу коэффициента Джини положены доходы после уплаты налогов без поправки на величину объекта налогообложения. В поздних цифровых рядах (чёрные квадраты) коэффициент Джини ниже, так как в его основе лежат располагаемые доходы населения с поправкой на величину домохозяйства. В 1980-1990-е гг. принадлежащая богатейшему проценту британцев доля совокупного валового дохода (помечена треугольниками) возрастает. Этот прирост частью объясняется проведённой в 1990 г. реформой налоговой системы (отказ от налогообложения семейных пар в пользу индивидуального налогообложения). Доля населения Великобритании, живущего в бедности (изображена на линии с крестами), - процент людей, проживающих в семье, чей располагаемый (и скорректированный) доход составляет менее $60 \%$ среднего дохода по стране. Ромбами (которым соответствует правая шкала) показаны доходы верхней децили населения (10\% от богатейших жителей) относительно доходов занятого полный день медианного взрослого работника (находящегося посередине кривой распределения доходов).

\section{Рис. 1.2. Неравенство в Великобритании, 1913-2013 гг..}

12 По мнению автора, результаты переписи населения США (вплоть до 1960-х гг.) говорят о том, что к 1944 г. процесс сокращения неравенства прекратился.

13 Эпоха джаза, или Век джаза, - период истории США с момента окончания Первой мировой войны и до начала Великой депрессии, когда была очень популярна джазовая музыка. - Примеч. ред. 
В верхней части имущественной пирамиды в 1979-1992 гг. доля совокупного валового дохода, принадлежащего богатейшему 1\% граждан, выросла наполовину, а к 2012 г. по сравнению с 1979 г. увеличилась более чем вдвое. Даже с учётом изменения ставки налога на прибыль (Закон о налоговой реформе 1986 г. привёл к перераспределению дохода между корпоративным сектором и индивидуальными налогоплательщиками) такое увеличение представляется значительным. Что касается доли валового дохода богатейших граждан, то мы, глядя на период до начала Второй мировой войны, в течение первых 50 лет констатируем общее снижение. Первоначально оно произошло во время Первой мировой войны, однако к концу «ревущих» 1920-х гг. сокращение доли было компенсировано. Затем снижение вновь продолжилось: после Великого краха 1929 г. и ещё раз - во время Второй мировой войны. На сегодня доля богатейшего процента населения США вернулась к своим значениям столетней давности. В настоящее время эта группа граждан США присваивает около одной пятой совокупного валового дохода американцев (это означает, что она - по сравнению с её долей в численности населения - получает в среднем в 20 раз больший доход). В самой этой группе (богатейший 1\%) также существует значительное неравенство: доля богатейшего $1 \%$ от тех, кто входит в богатейшую группу (то есть, богатейшего $0,01 \%$ от всего населения), также составляет около одной пятой совокупного дохода этой группы населения. Это означает, что $1 / 10000$ населения получает $1 / 25$ общего дохода. Верхний ярус распределения напоминает русскую матрёшку: в каждом его сегменте мы находим некую степень неравенства, воспроизводимую в остальной части указанного верхнего яруса ${ }^{14}$.

\section{Сравнение тенденций в США и Великобритании}

Как опыт Великобритании соотносится с переменами в степени неравенства, произошедшими в США? Нередко полагают, что ситуация в Великобритании является бледной копией того, что происходит в США, и график динамики британского неравенства можно получить, поменяв лишь название страны в заголовке. В этом есть доля правды. Как показано на рисунке 1.2, в Великобритании статистические ряды совокупного неравенства, начавшиеся в 1938 г., в дальнейшем (когда они были возобновлены после Второй мировой войны) показали снижение примерно на 7 процентных пунктов. (При анализе этих графиков читателю следует сосредоточиться на изменениях во времени; уровни неравенства в двух странах не вполне сопоставимы, поскольку доходы в США и Великобритании измеряются поразному.) Затем, в 1980-е гг., общий уровень неравенства вырос. После 1979 г. в Великобритании произошёл «Поворот к неравенству», аналогичный американскому. Вплоть до конца 1970-х гг. доли доходов богатейших граждан сокращались, но затем вновь начали расти. В 1919 г. доля валового дохода наиболее обеспеченного процента населения составляла 19\% и к 1979 г. сократилась примерно до 6\%; с тех пор она более чем удвоилась. Доля валового дохода богатейшего процента жителей Великобритании меньше соответствующей доли в США, однако эта группа по-прежнему получает восьмую часть совокупного валового дохода.

Неудивительно поэтому, что Роберт Солоу, писавший в 1960 г. о распределении доходов, обратил внимание на «сходство британского и американского опыта в XX веке» [Solow 1960: 135]. Однако с тех пор появились и различия. В 1980-х гг. рост общего неравенства в Великобритании был гораздо большим, чем в США. В 1979-1992 гг. рост коэффициента Джини в Великобритании составил примерно 9 процентных пунктов, то есть вдвое больше, чем в США. После 1992 г. увеличение, напротив, было небольшим: в 2011 г. коэффициент был, в сущности, таким же, как в предыдущие 20 лет. Несовпадение по срокам, а также общая динамика увеличения показывают, что Великобритания и США следовали разными путями, а различия дают нам ценную информацию об основных движущих силах этого про-

14 Из года в год персональный состав богатейшего 1\% налогоплательщиков меняется. Тем не менее их нисходящая мобильность ограничена. Из тех, кто в 1987 г. (в возрасте 35-40 лет) входил в богатейший 1\% населения, через 20 лет в той же группе оставались 24\%, а в состав богатейшей децили (верхних 10\%) входили 70\%; см. таблицу 1 в: [Auten, Gee, Turner 2013]. 
цесса. В наших поисках объяснения растущего неравенства одним из ценных источников информации является изучение «различий в различиях» - различий между странами в ходе изменений во времени.

Читателей, озабоченных положением в Великобритании, может утешить тот факт, что за последние 20 лет в этой стране никакого увеличения общего неравенства доходов, измеряемого с помощью коэффициента Джини, не произошло. Однако при этом уровень неравенства упорно остаётся выше уровня, наблюдавшегося в 1960-е и 1970-е гг. Чтобы в этом смысле вернуться во времена группы Beatles, пришлось бы снизить коэффициент Джини примерно на 10 процентных пунктов. Что это означает? Предположим, что достичь такого снижения нужно за счёт одних лишь налогов и трансфертов. Основываясь на разумных предположениях о величине налоговых ставок и государственных расходов, мы заключаем, что увеличение ставки подоходного налога, необходимое для снижения коэффициента Джини для располагаемого дохода с 35 до 25\%, составило бы 16 процентных пунктов ${ }^{15}$. Величина требуемого повышения налоговых ставок указывает на тот факт, что сокращение неравенства не может быть достигнуто исключительно за счёт фискальных мер. В этом убеждении мы ещё более укрепимся, как только представим себе вероятное воздействие такого повышения ставок на экономические стимулы. Именно поэтому многие из предложенных в этой книге политических мер направлены на уменьшение степени неравенства при распределении рыночных доходов. По этой же причине радикальная политика по сокращению неравенства обязана затрагивать всю систему управления. Однако на данный момент обнаруживается, что мы столкнулись с серьёзной проблемой.

\section{Неравенство в мировом маситабе}

Масштаб проблемы становится понятным, если мы сравним неравенство доходов в разных странах мира. Рисунок 1.3 отражает коэффициент Джини для скорректированного располагаемого дохода домашних хозяйств в разных странах. Выборка представительна в алфавитном порядке - от Австралии до Уругвая, а с учётом совокупного дохода на душу населения - от Индии до США. Проводить такие сравнения не столь уж просто, и источники этих данных мы подробнее обсудим в следующей главе.

Как следует из рисунка 1.3, в Китае и Индии коэффициенты Джини близки к 50\%, или примерно вдвое выше значений, наблюдаемых в Скандинавских странах в верхней части графика. (В Южной Африке индекс ещё выше - около 60\%.) Коэффициент Джини также весьма высок - выше 40\% - в Латинской Америке (на примере Бразилии и Мексики). Далее (после Израиля) следуют США, а затем и Великобритания. (Значение индекса для США здесь ниже, чем на рисунке 1.1, так как в этом случае доход измеряется до вычета налогов.) Общее неравенство доходов в двух англосаксонских странах намного выше, чем в странах континентальной Европы, и гораздо выше, чем в Скандинавских странах ${ }^{16}$.

15 Предположим, что для большей части шкалы доходов мы можем - путём введения неизменной ставки налога и единого пособия для всех граждан - добиться аппроксимации системы налогов и трансфертов (таково разумное первое предположение). В таком случае валовой доход $Y$ становится чистым доходом $(1-t) Y+A$, где $t$ - налоговая ставка; $A$ - пособие, положенное всем гражданам (его можно рассматривать как личную налоговую льготу). Если А одинаково для всех, то коэффициент Джини для располагаемого дохода равен $(1-t)$ коэффициента Джини для рыночного дохода $(Y)$, делённого на отношение среднего располагаемого дохода к среднему рыночному доходу. Если государственные расходы на товары и услуги (здравоохранение, образование, оборону и т. д.) поглощают 20\% налоговых поступлений, то последнее соотношение равняется 80\%. Предположим далее, что коэффициент Джини для рыночных доходов составляет $50 \%$. В таком случае снижение коэффициента Джини для располагаемого дохода в результате повышения ставки налога на $D t$ составит половину $(0,5)$ величины $D t$ со знаменателем 0,8 . Если перевернуть соотношение, то получится, что требуемое увеличение ставки налога равно: $0,8 / 0,5=1,6$, умноженному на величину желаемого снижения коэффициента Джини для располагаемого дохода.

16 Подробнее о неравенстве доходов в странах ОЭСР см.: [Brandolini, Smeeding 2011; Morelli, Smeeding, Thompson 2011]. 


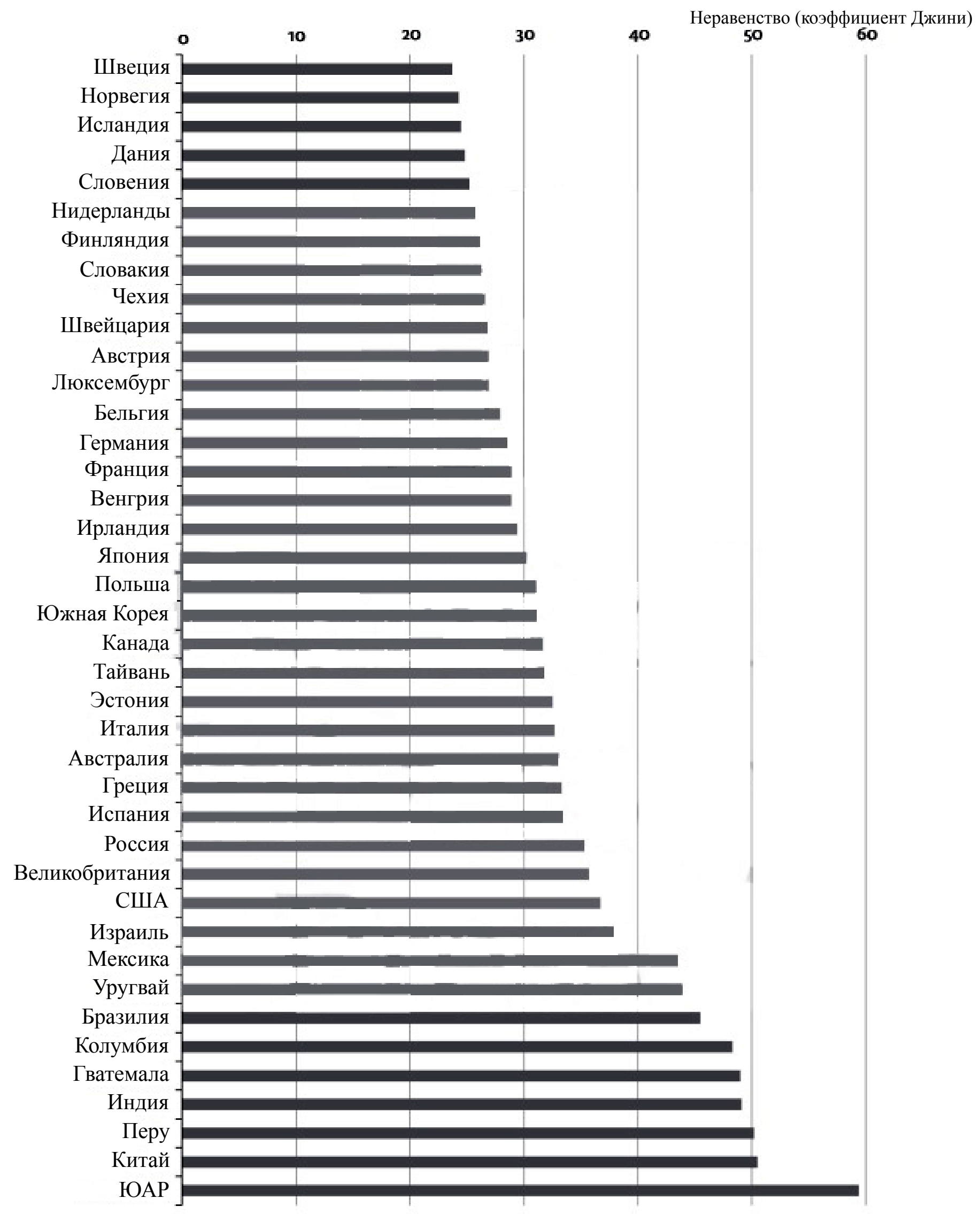

Источник: LIS Key Figures. URL: http://www.lisdatacenter.org/data-access/key-figures/download-key-figures/ (Дата обращения: 30 ноября 2014 г.).

Рис. 1.3. Неравенство в отдельных странах мира, 2010 г. 


\section{Неравенство (коэффрищиент Джини)}

Неравенство измерено коэффициентами Джини на основе скорректированного располагаемого дохода домашних хозяйств (доход за вычетом налогов и трансфертов). Коэффициент имеет широкий диапазон: от 23,7\% в Швеции до 59,4\% в Южной Африке.

Межстрановое сравнение показывает всю сложность попыток обратить вспять рост неравенства доходов, происходящий с 1970 г. Для Великобритании задача по снижению коэффициента Джини на 10 процентных пунктов означала бы, что эта страна должна уподобиться Нидерландам. Для США снижение индекса на 7,5 процентного пункта означало бы их уподобление Франции. Для других стран Организации экономического сотрудничества и развития (ОЭСР) дистанция не столь велика. В Австралии коэффициент Джини с 1980 г. вырос на 4 процентных пункта (образцом для подражания вновь была бы Франция).

\section{Должны ли мы сосредоточиться на преодолении одной лишь бедности?}

До сих пор мы обсуждали факты, свидетельствующие о неравенстве доходов. Гарвардский экономист Мартин Фельдштейн, инициатор исследований по экономике социального обеспечения, решительно утверждает, что «акцент следует делать не на распределении доходов и не на степени неравенства вообще, а на борьбе с бедностью», и это мнение распространено весьма широко [Feldstein 2005: 12]. Я разделяю его обеспокоенность тем, что происходит с людьми, оказавшимися в нижней части шкалы доходов. Именно повторное «открытие» факта бедности в Великобритании в 1960-е гг. — в частности, издание в канун Рождества 1965 г. книги двух авторов, Брайана Абель-Смита и Питера Таунсенда, «Тhe Poor and the Poorest» («Бедные и беднейшие») [Abel-Smith, Townsend 1965] — подвигло меня на исследование бедности как явления. Так родилась и моя первая книга «Poverty in Britain and the Reform of Social Security» («Бедность в Великобритании и реформа социального обеспечения») [Atkinson 1969]. Сегодня, то есть 50 лет спустя, борьба с бедностью занимает прочное место в политической повестке, а государства ставят себе чёткие цели по преодолению этого социального недуга. По итогам Копенгагенского саммита ООН по социальным проблемам (1995 г.) правительство Ирландии, действуя в рамках принятой в 1997 г. «Национальной стратегии по борьбе с бедностью» провозгласило собственную цель сокращения масштабов бедности в стране. В 1999 г. правительство Великобритании, которое тогда возглавлял Тони Блэр, приняло официальную доктрину искоренения детской бедности, чтобы к 2020 г. избавиться от этого печального явления. Преемник Блэра, Гордон Браун, юридически закрепил это стремление в Законе против детской бедности от 2010 г. (Child Poverty Act 2010). В «Повестке для Европы на период до 2020 г.» (Europe 2020 Agenda) Европейский союз (ЕС) поставил себе цель снизить (как минимум на 20 млн чел.) количество людей, испытывающих серьёзные материальные лишения и живущих на грани обнищания либо входящих в состав «семей, оставшихся без работы». Стоит напомнить, что в настоящее время общая численность населения ЕС составляет примерно 500 млн чел. ${ }^{17}$

Несмотря на эти благие намерения, прогресс в деле сокращения бедности в развитых странах остаётся медленным. На рисунках 1.1 и 1.2 отображено, как с течением времени эволюционировала бедность в США и Великобритании. Рассматриваемый с учётом покупательной способности порог бедности в США оставался на постоянном уровне, в отличие от ситуации в Великобритании и Евросоюзе ${ }^{18}$. Неудивительно, что в США официальный уровень бедности снизился с 33\% в 1948 г. до 19\% в тот период,

17 Целевые ориентиры стратегии «Европа-2020» описаны на сайте Европейской комиссии: URL: http://ec.europa.eu/ europe2020/targets/eu-targets/; см. также: [Atkinson, Marlier 2010].

18 В ЕС порог бедности составляет 60\% от среднего выровненного (equivalised) располагаемого семейного дохода в стране. Следовательно, порог бедности повышается или снижается в зависимости от изменений среднего дохода. 
когда президент Линдон Джонсон провозгласил в 1964 г. «Войну с бедностью». До конца 1960-х гг. бедность в США продолжала сокращаться, но с тех пор существенного улучшения ситуации не произошло, а абсолютное число бедняков даже увеличилось, поскольку население страны выросло. Сегодня ниже официальной черты бедности живут около 45 млн американцев.

В Великобритании (см. рис. 1.2) уровень бедности, измеренный пороговой величиной в виде определённой доли от среднего дохода, в 1992-2011 гг. снизился с 22 до 16\%. Это снижение, начавшееся при консервативном правительстве Джона Мейджора, оказалось существенным и показывает, что бедность можно уменьшить. Оправдывает ли это стратегию, призывающую «сосредоточиться на борьбе с бедностью»? В Великобритании снижение уровня бедности сопровождалось заметным увеличением доли крупнейших доходов. В отношении роста частных состояний новое правительство лейбористов - да простится мне такое определение - «дало сильную слабину». Тем не менее достигнутое за последние 20 лет сокращение бедности - и здесь нужно воздать должное усилиям британских властей оставляет нынешний уровень бедности в стране выше уровня 1960-х и 1970-х гг., который в то время воспринимался как глубоко шокирующий. В 1965 г., когда этот уровень был на 3\% ниже сегодняшнего, в Великобритании была основана «Группа содействия искоренению детской бедности» (The Child Poverty Action Group).

В Европейском союзе доля лиц, подверженных риску обнищания, в последние годы увеличилась ${ }^{19}$. В 2014 г. Комитет социальной защиты населения (The Social Protection Committee) сообщил: «Последние данные об условиях жизни и уровне доходов в Европейском союзе показывают, что ЕС не демонстрирует прогресса в достижении своих целей искоренения бедности и социального отчуждения (в рамках стратегии “Europe 2020”)». Происходит нечто прямо противоположное: «После 2008 г. количество людей, живущих в условиях бедности или социального отчуждения, в странах Европейского союза выросло на 6,7 млн, достигнув в 2012 г. в общей сложности 124,2 млн чел. (то есть бедным был почти каждый четвёртый европеец). В 2011 и 2012 гг. бедность и социальное отчуждение увеличились более чем в трети государств — членов ЕС» [Social Protection Committee 2014: 7].

Нам предстоит ещё пройти долгий путь. На мой взгляд, чтобы искоренить бедность в богатых странах, необходимо мыслить более масштабно, за пределами стратегий, применяемых сегодня. Нужно увидеть наше общество в целом и признать, что в нём существуют важные взаимосвязи. Экономическая теория склонна отрицать или преуменьшать взаимозависимость между результатами хозяйственной деятельности индивидуумов (или семей), но Джон Донн был прав, когда писал: «Нет человека, который был бы как Остров, сам по себе» [Donne 1962: 538]. То, что происходит в верхней части шкалы распределения доходов, влияет на тех, кто находится в её нижней части. Как сто лет назад отмечал Тоуни, «то, что вдумчивые богачи называют проблемой бедности, вдумчивые бедняки столь же справедливо называют проблемой богатства» [Tawney 1913].

Рассуждая прагматичнее, можно спросить: способны ли страны достичь низкого уровня бедности, сохраняя при этом высокий уровень максимальных доходов? Чтобы проверить это, я представил на рисунке 1.4 показатели по 15 странам - членам ОЭСР. Перекрещивающиеся линии на графике делят страны на группы в зависимости от того, находятся они выше или ниже среднего уровня. Из 15 стран 11 расположены в верхней правой или нижней левой четвертях графика. Только Швейцария имеет уровень бедности ниже среднего, одновременно сохраняя уровень максимальных доходов выше среднего. Как правило, большей степени бедности на одном полюсе соответствует увеличенная доля максимальных доходов на другом.

19 Анализ стратегии «Европа-2020» в среднесрочной перспективе см.: [Frazer et al. 2014]. 


\section{Растущая дисперсия доходов}

Слово «дисперсия» в названии раздела подчёркивает тот очевидный, но нередко упускаемый из виду факт, что не все различия в результатах экономической деятельности объясняются неоправданным неравенством. Иногда одни люди зарабатывают больше других по вполне обоснованным причинам например, отрабатывая больше часов, выполняя неприятную работу или беря на себя повышенную ответственность. Одним из веских аргументов в пользу различий в оплате труда служит то, что некоторые люди вкладывают силы и средства в обучение профессиям, требующим более высокой квалификации. Такое объяснение различий в оплате труда, данное с учётом «человеческого капитала», имеет давнее происхождение. Уже в «Богатстве народов» (1776) Адам Смит ясно заявил: «Человек, изучивший с затратой большого труда и продолжительного времени какую-либо из тех профессий, которые требуют чрезвычайной ловкости и искусства, может быть сравнен с дорогою машиною. Следует ожидать, что труд, которому он обучается, возместит ему, сверх обычной заработной платы за простой труд, все расходы, затраченные на обучение, с обычной, по меньшей мере, прибылью на капитал, равный этой сумме расходов» [Smith 1903: 78]. Это простое указание на то, что лежит в основе премии к заработной плате за более высокий уровень образования, объясняет минимум два обстоятельства: (1) почему различия необязательно подразумевают наличие неравенства; (2) почему подобным образом не всегда удаётся объяснить всю наблюдаемую разницу. Вполне может быть, что инвестиции в человеческий капитал, сделанные образованным работником, приносят больший (или меньший) доход, чем обычная прибыль на вложенный капитал. В своём новаторском исследовании, посвящённом профессиональным заработкам в США в 1930-е гг., лауреаты Нобелевской премии Милтон Фридман и Саймон Кузнец заключают, что «реальная разница в заработках квалифицированных и неквалифицированных работников представляется явно большей, чем разница, которая могла бы компенсировать требуемые для этого дополнительные капиталовложения» [Friedman, Kuznetz 1945: 84]. В этом смысле указанная разница действительно представляла собой неравенство.

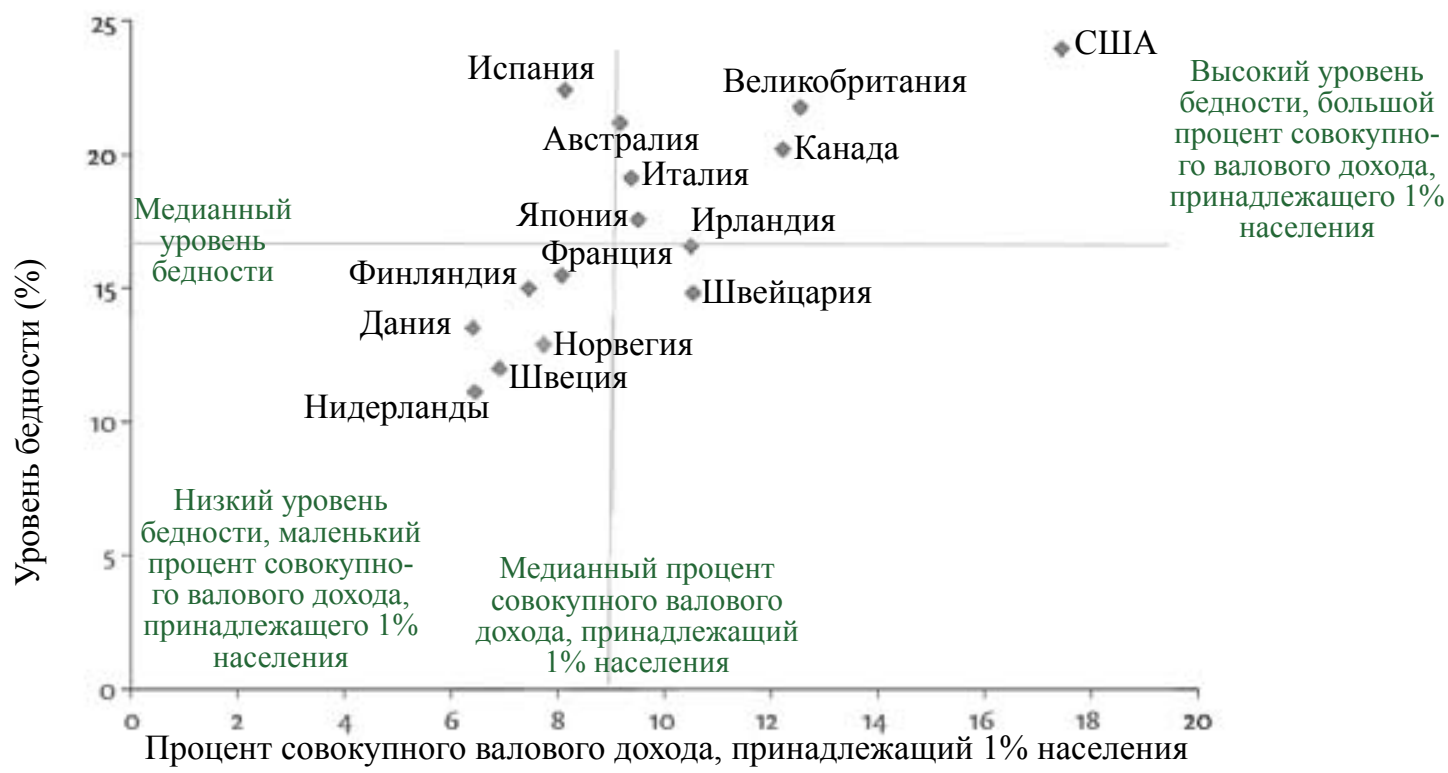

Источники: Уровни бедности: LIS Key Figures, URL: http://www.lisdatacenter.org/data-access/key-figures/download-keyfigures/ (Дата обращения: 30 ноября 2014 г.). Доли дохода богатейших групп населения: The World Top Incomes Database; cм. URL: http://topincomes.g-mond.parisschoolofeconomics.eu/ (Дата обращения: 9 декабря 2014 г.).

Примечание: В 2010 г. в США уровень относительной бедности (доля населения, живущего на доходы, составляющие менее $60 \%$ от среднего уровня) был равен $24,7 \%$, а доля совокупного валового дохода, принадлежащая богатейшему проценту населения (без учёта доходов от прироста капитала), составляла 17,5\%.

Рис. 1.4. Бедность и доли максимальных доходов в отдельных странах, 2010 г. 
Долгосрочная эволюция распределения доходов в США и Великобритании показана на рисунках 1.1 и 1.2 (доходы верхней децили). Эти графики легче понять, если представить себе всех людей, получающих доходы, выстроенными в шеренгу в порядке увеличения их заработков. Далее «статистик» делит людей на десятки и просит тех, кто стоит в начале каждого десятка, выйти на шаг вперёд. Человек, стоящий в начале шестого десятка, считается медианнылм, то есть стоящим в середине, тогда как человек в начале последнего десятка открывает верхнюю дециль. На приведённых графиках отображено ежегодное отношение доходов лиц, относящихся к верхней децили, к доходам медианного (среднего) работника. Таким образом, в 1952 г. в США это отношение составляло около 150\%. Приведённый график продлевается назад во времени несколько дальше, чем это принято в исследованиях дисперсии заработной платы, которые имеют тенденцию сосредоточиваться на событиях после 1970 гг. Однако нам важно поместить события последних десятилетий в исторический контекст. Очевидно, что в США увеличение доли максимальных доходов началось задолго до 1970 г. В 1952-1972 гг. относительное преимущество верхней децили выросло со 150 до 194\% от медианного дохода; увеличение, соизмеримое с тем, которое произошло в период с 1972-2012 гг. Иным был опыт Великобритании. Если в 1950-е и в начале 1960-х гг. дисперсия доходов расширяется, то с середины 1960-х до 1979 г. доходы верхней децили по отношению к медианному доходу уменьшаются. Причины этого обсуждаются в следующей главе. Между двумя англосаксонскими странами не только отсутствует синхронизация, но и наблюдается разница в масштабах общего увеличения: в Великобритании оно меньше, чем в США (в отличие от зафиксированной нами тенденции в отношении общего неравенства доходов). В Великобритании дисперсия доходов увеличилась меньше - притом что неравенство доходов в целом выросло больше, - чем в США.

\section{Краткая послевоенная история неравенства в Великобритании и США}

\begin{tabular}{|c|c|c|c|c|}
\hline & $\begin{array}{l}1950-\mathrm{e}- \\
\text { середина } \\
1960-\text { х гг. }\end{array}$ & $\begin{array}{c}\text { Середина } \\
\text { 1960-х - } \\
\text { конец 1970-х гг. }\end{array}$ & 1980-е гг. & $\begin{array}{c}1990-е- \\
\text { настоящее время }\end{array}$ \\
\hline $\begin{array}{l}\text { Дисперсия ин- } \\
\text { дивидуальных }\end{array}$ & $\begin{array}{c}\text { Увеличение } \\
\text { в Великобритании }\end{array}$ & $\begin{array}{c}\text { Уменьшение } \\
\text { в Великобритании }\end{array}$ & $\begin{array}{c}\text { Увеличение } \\
\text { в Великобритании }\end{array}$ & $\begin{array}{c}\text { Увеличение } \\
\text { в Великобритании }\end{array}$ \\
\hline доходов & $\begin{array}{c}\text { Увеличение } \\
\text { в США }\end{array}$ & $\begin{array}{c}\text { Увеличение } \\
\text { в США }\end{array}$ & $\begin{array}{c}\text { Увеличение } \\
\text { в США }\end{array}$ & $\begin{array}{c}\text { Увеличение } \\
\text { в США }\end{array}$ \\
\hline \multirow{2}{*}{$\begin{array}{c}\text { Неравенство } \\
\text { в доходах домохо- } \\
\text { зяйств }\end{array}$} & $\begin{array}{c}\text { Стабильное } \\
\text { в США }\end{array}$ & $\begin{array}{c}\text { Стабильное } \\
\text { в США }\end{array}$ & $\begin{array}{c}\text { Увеличение } \\
\text { в США }\end{array}$ & $\begin{array}{c}\text { Увеличение } \\
\text { в США }\end{array}$ \\
\hline & $\begin{array}{c}\text { Стабильное } \\
\text { в Великобритании }\end{array}$ & $\begin{array}{c}\text { Уменьшение } \\
\text { в Великобритании }\end{array}$ & $\begin{array}{l}\text { Резкое увеличение } \\
\text { в Великобритании }\end{array}$ & $\begin{array}{c}\text { Стабильное } \\
\text { в Великобритании }\end{array}$ \\
\hline
\end{tabular}

Итак, перед нами более нюансированный сюжет, нежели история одного лишь «растущего неравенства». Как видно из таблицы 1.1, различия существуют между периодами, между странами, между заработками отдельных лиц и между доходами домохозяйств. Эти различия помогают нам понять детерминанты неравенства. Изучая эпизоды, обведённые в таблице 1.1, можно поискать ответы на конкретные вопросы. Как в 1950-е и 1960-е гг. Соединенным Штатам удавалось поддерживать в целом стабильный уровень неравенства доходов, несмотря на расширение дисперсии доходов населения? Как Великобритании удалось уменьшить дисперсию доходов в 1965-1979 гг.? Почему в 1980-е гг. неравенство доходов в Великобритании возрастало гораздо стремительнее? Эти вопросы, наряду с опытом других стран ОЭСР, будут рассмотрены в следующей главе.

\section{Параметры неравенства}

Итак, мы бросили первый взгляд на ситуацию с неравенством; прежде чем пойти дальше, нужно сделать шаг назад и уточнить понятия, лежащие в основе статистических данных. У неравенства есть не- 
мало параметров, и в наших рассуждениях ряд важных измерений до сих пор отсутствовал. Мало того, даже в рамках освещённых вопросов читатель мог заинтересоваться, какие измерения были включены в наши рассуждения, а какие - нет. Например, графики на рисунках 1.1 и 1.2 наводят читателя на вопрос: неравенство - в чём и между кем?

\section{Неравенство между кем?}

До сих пор мы говорили о доходах домохозяйств или - при обсуждении заработков - о доходах физических лиц. Но возможны и другие объекты анализа. Одно домохозяйство может состоять из нескольких семей, а в семье могут жить представители нескольких поколений. Какое из этих делений следует использовать? Ответ на вопрос отчасти зависит от того, в какой мере члены семьи имеют одинаковые права пользования её ресурсами. Если в этом имеется полное равенство, то описанные выше расчёты, основанные на общем доходе домохозяйства, остаются верными. Там, где доступ к ресурсам неравный, появляется основание для выделения конкретных «хозяйствующих субъектов», или нуклеарных семей, образующих «большую» семью. В рамках большой семьи мы вправе отдельно рассматривать взрослых детей, остающихся жить в родительском доме. В структуре домохозяйства пожилые родители, живущие со своими детьми, также представляют собой отдельную семейную ячейку. В течение многих лет бедность в Великобритании рассчитывалась именно на семейной основе, что давало цифры, которые были выше, но показывали менее резкий рост, чем отражено на рисунке 1.2. Цифры были выше, так как предполагалось, что каждая семейная ячейка в рамках домохозяйства существует на собственные доходы. В то же время сегодняшние методы оценки могут занижать истинные масштабы бедности, поскольку предполагается, что ресурсы семьи равномерно делятся на всех её членов. Эти методы способны скрывать бедность, обусловленную неравенством внутри домохозяйства. Иными словами, если в период ухудшения экономических условий молодёжь возвращается в семейное гнездо, то методика измерений на основе единого домохозяйства способна камуфлировать масштабы увеличения неравенства.

Выбор единицы измерения зависит не только от того, каким образом доход распределяется между членами семьи, но и от нашего представления о том, как они контролируют её ресурсы, а также от понимания степени их индивидуальной зависимости. Так, если мы полагаем, что молодёжь должна быть независимой от родителей, то в качестве расчётной можно использовать «внутрисемейную единицу», состоящую из взрослых и детей-иждивенцев, но не включающую взрослых детей, оставшихся жить в родном доме. Этот метод повышает оценочную степень бедности и неравенства доходов, ибо даже если доходы семьи объединяются в общий пул, то распределение её ресурсов во внимание не принимается. В общественной дискуссии эта проблема зачастую игнорируется: учитывается лишь «зависимость от социальных выплат», но не зависимость человека от других членов семьи. Однако в прошлом цель государственной политики состояла именно в обеспечении финансовой независимости пожилых людей от их взрослых детей. За тем, что в иных обстоятельствах могло бы показаться чисто статистическим вопросом, скрывается проблематика социальных ценностей и ожиданий: должны ли мы оценивать неравенство и бедность в масштабах единого домохозяйства или в рамках отдельной семьи?

\section{Неравенство в чём?}

Неравенство в целом для Великобритании (см. рис. 1.2) измеряется по показателю располагаемого дохода домохозяйства с поправкой на размер и состав семьи (для США то же неравенство, представленное на рисунке 1.1, измеряется по показателю дохода до уплаты налогов). Структура доходов домохозяйства схематично дана на рисунке 1.5 , который я называю наглядным пособием по семейному доходу. Для читателей, которые - по понятным причинам - с трудом различают многочисленные трактовки дохода, пособие может оказаться полезным на нескольких этапах прочтения нашей книги. 
Доходы первого члена семьи

+
Доходы второго члена семьи

$+$

Доходы от инвестированного капитала и сбережений

$+$

Трансфертные платежи из частных источников

$+$

Государственные трансферты

$=$

Совокупный валовый доход

一

Прямые налоги

$=$

Располагаемый доход домохозяйства,

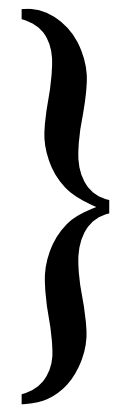

Рыночный доход домохозяйства
Располагаемый доход домохозяйства,
поделённый на число эквивалентных взрослых членов семьи
Располагаемый доход домохозяйства + Стоимость государственных услуг

Располагаемый доход домохозяйства,
поделённый на число эквивалентных взрослых членов семьи
Располагаемый доход домохозяйства + Стоимость государственных услуг

Скорректированный располагаемый доход домохозяйства

Расширенный доход домохозяйства

Рис. 1.5. Наглядное пособие по семейному доходу

Для начала, поскольку мы мыслим в категориях целого домохозяйства, нам необходимо суммировать доходы каждого члена семьи. Человек с небольшим доходом может состоять в браке с тем, кто зарабатывает гораздо больше: супруга церковного проповедника может оказаться инвестиционным банкиром. На схеме указаны два человека, но, разумеется, членов семьи (домашнего хозяйства) может быть несколько. Доходы включают не только заработную плату и оклады работников по найму, но и доходы самозанятых членов семьи. Этот источник характерен тем, что подразумевает доход не только на вложенный труд (то есть число отработанных часов), но и на инвестированный капитал. К этому добавляется доход от сбережений, который может иметь форму процентов по облигациям или банковским счетам, либо дивидендов на акции, либо арендной платы за сдачу внаём личного имущества. Сюда же добавим трансфертные платежи из частных источников, например пенсии, а также государственные трансферты от имени правительства. Это и составляет совокупный валовой доход домохозяйства. Вычитая подоходный налог и другие прямые налоги (такие как налоги на социальное обеспечение), мы, в итоге получаем располагаемый доход. Следующий уровень схемы учитывает различия в размерах и составе семьи как домохозяйства. Доход семьи, состоящей из мужа, жены и двоих детей, выглядит не так солидно, как доход той же величины, причитающийся одному человеку. Как говорит один мой коллега, «в семье с двумя детьми одной булочкой за пенни не обойдёшься» (расходы умножаются на число иждивенцев). В реальности поправка на разницу в составе семьи не является прямо пропорциональной душевому доходу, поскольку наличествует «экономия за счёт масштаба». В домохозяйстве моего коллеги имеется лишь одна система центрального отопления. В этом случае вступает в силу понижающий коэффициент (equivalence scale), позволяющий учесть тот факт, что не все расходы умножаются на число членов семьи. Один из простых понижающих коэффициентов — квадратный корень 
из числа, определяющего размеры домохозяйства (по количеству членов семьи). Например, доход семьи из четырёх человек делится на два (что представляет собой квадратный корень из четырёх). В то же время представленная выше статистика оперирует чуть более сложным коэффициентом (известным как модифицированная шкала ОЭСР. В этом случае величина расходов домохозяйства на первого взрослого члена семьи умножается на единицу ${ }^{20}$, на остальных взрослых - на 0,5, на каждого ребёнка в семье - на 0,3.

Цель моего пособия - объяснить читателю структуру располагаемого дохода домохозяйства с поправкой на величину и состав семьи. Ниже этот доход фигурирует как скорректированный доход домохозяйства (household equivalised income). Впрочем, польза от моего пособия этим не ограничивается. Из схемы, приведённой на рисунке 1.5 , явствуют элементы, объясняющие становление доходов домохозяйства. Однако прежде следует спросить, каков принцип формирования составляющих дохода, использованный на рисунке 1.5. Как правило, экономисты согласны в том, что доход равен сумме всех поступлений - будь то в денежном выражении или в натуральной форме, 一 которые накапливаются за определённый период. Или, что то же самое, доход равен максимальному объёму ресурсов, которые домохозяйство может потреблять без уменьшения чистой стоимости своих активов за вычетом обязательств. Это определение является всеобъемлющим по охвату и выходит за рамки большинства определений дохода, применяемых в целях налогообложения. В принципе, оно включает все доходы в натуральной форме, в том числе и овощи, выращенные в вашем саду (которыми налоговые органы обычно не интересуются). Оно же, безусловно, охватывает и выплаты в натуральной форме как часть - порой довольно существенная - компенсации за труд. Это определение включает также доход в натуральной форме, полученный домохозяином от эксплуатации недвижимости. Владение домом не приносит денежного дохода, но избавляет владельца от необходимости платить арендную плату соизмеримой величины. Если мы ищем всеобъемлющего определения дохода, то следует учитывать такую его статью, как вменённая арендная плата (imputed rent). Эта статья обычно включается в счета национального дохода (см. следующий раздел) и является весомой: в 2012 г. в Великобритании она приближалась к $10 \%$ от ВВП. То же касается других активов (таких как мебель, домашнее ИТ-оборудование и потребительские товары длительного пользования), но их экономическая значимость, вероятно, будет гораздо меньшей. В приведённой выше статистике доходов вменённая арендная плата отсутствует, но она, безусловно, должна учитываться при проведении реформ, влияющих на рынок жилья.

В статистике доходов отсутствует ещё один важный источник поступлений в натуральной форме: стоимость государственных услуг (таких как здравоохранение, образование и социальное обеспечение). На рисунке 1.5 они добавляются к располагаемому доходу семьи, в результате чего получается расширенный доход (extended income) домохозяйства. Оценить стоимость государственных услуг нелегко, но они, безусловно, добавляются к ресурсам, которыми располагают домохозяйства. Например, если бы не было государственного образования, то родители финансировали учёбу детей в частных школах из своего располагаемого дохода. По объёму государственных услуг страны мира различаются между собой, поэтому отсутствие тех или иных услуг влияет на результаты международного сопоставления уровней неравенства. Как мы увидим далее, страны с меньшими государственными расходами, как правило, имеют больший объём частных расходов, хотя их распределение, вероятно, будет неодинаковым. Оценивая государственные услуги по стоимости с точки зрения правительства, мы получаем в европейских странах показатель неравенства в расширенных доходах, значительно уступающий показателю неравенства в располагаемых доходах (см.: [Aaberge, Langørgen, Lindgren 2013]).

Принятие всеобъемлющего определения дохода предполагает полный учёт изменений в стоимости активов, то есть учитывает тот факт, что за период оценки эти активы могут прибавить или потерять в

20 Подробнее о шкалах эквивалентности см.: [Atkinson et al. 2002]. 
стоимости. Подобные изменения не отражаются на показателях национального дохода, однако с точки зрения платёжного баланса домохозяйств они, безусловно, влияют на покупательную способность. Если по итогам года стоимость принадлежащих вам акций выросла, то вы можете, не уменьшая своего капитала, потратить эту сумму. Необходимо различать начисленные и реализованные прибыли (или убытки). Первые - начисленные - представляют собой прибыль на бумаге; последние - реализованные - суть доходы, обращённые в денежные средства путём продажи актива. Именно реализованные прибыли обычно облагаются налогами и появляются в статистике доходов. Заметно повлиять на статистику, в частности, на долю измеряемых максимальных доходов, способен прирост капитала. В 2012 г. в США доля доходов богатейшего 1\% населения, не считая прироста капитала (см. рис. 1.1), составила 19,3\%, тогда как доля доходов, включая реализованный доход от прироста капитала, была примерно на 3 процентных пункта выше и составляла 22,5\% ${ }^{21}$. В той мере, в какой реализованный прирост капитала оказывается меньше общей суммы начисленных доходов (поскольку многие владельцы активов не продают), увеличение неравенства оказывается заниженным. Однако эти расчёты не учитывают инфляцию, и при начислении денежных доходов сумма реального прироста капитала оказывается завышенной. Если за тот или иной период цены выросли, то покупательная способность (назовём это «реальная стоимость») ваших активов сократилась. Так что, если ваши акции стоимостью 1000 дол. подорожали до 1200 дол., то прирост денежного капитала составил 200 дол.; если за это время цены выросли на 10\%, то ваш реальный выигрыш составит лишь 100 дол. Данный факт затрагивает более общий вопрос. Всеобъемлющее определение дохода предполагает чистую стоимость активов неизменной, которая принимается за их реальную стоимость. Любое владение активами приводит к потере капитала за счёт инфляции. От такого же снижения покупательной способности страдает держатель банковского счета с нулевой процентной ставкой. И наоборот, в случае пассивов (обязательств) происходит прирост капитала, поскольку выплаты по обязательствам с точки зрения покупательной способности уменьшаются. Меня всегда удивляло это пренебрежение к поправкам на инфляцию, столь актуальным для мелких вкладчиков, которые даже при низких темпах роста цен замечают, как уменьшаются их денежные вклады.

\section{А как насчёт неравенства в потреблении?}

До сих пор мы рассуждали о распределении экономических результатов в категориях дохода и прибыли, но они могут рассматриваться - на вполне разумных основаниях - не как самоцель, а как средство для достижения цели. Сайлас Марнер (Silas Marner), герой одноименного романа Джорджа Элиота [Eliot 1861], получал удовольствие от одного лишь подсчёта своих сокровищ, но большинство людей видят за банковскими счетами реальные цели. И конечной целью, по мнению многих экономистов, является потребление. Так полагают не только экономисты. В рецензии на книгу Тома Пикетти «Капитал в XXI веке» («Capital in the Twenty-First Century») [Piketty 2014] Билл Гейтс, соглашаясь с основными выводами автора, критикует его за «полное пренебрежение к категории потребления» [Gates 2014]. Если рассматривать потребление, а не доход, то выводы в отношении неравенства и бедности могут быть иными. Как утверждает Дейл Йоргенсон из Гарварда, «официальная американская статистика, в основе которой лежат семейные доходы, предполагает, что “Война с бедностью” закончилась поражением. Между тем оценка уровня бедности, основанная на цифрах семейного потребления, говорит о победе» [Jorgenson 1998: 79]. Брюс Майер и Джеймс Салливан полагают, что «переход от традиционных оценок бедности по уровню дохода к оценке бедности по уровню потребления (и, что особенно важно, с поправкой на смещение ценовых индексов) заставляет предположить, что в 1960-2010 гг. уровень бедности снизился на 26,4 процентного пункта, из которых 8,5 процентного пункта пришлись на период после 1980 г.» [Meyer, Sullivan 2012: 163]. Что касается неравенства в целом, то Дирк Крюгер и Фабрицио Перри считают, что «недавнее увеличение неравенства доходов в США не сопровожда-

21 Источник: World Top Incomes Database (WTID) (см. URL: http://topincomes.g-mond.parisschoolofeconomics.eu/). 
лось соответствующим увеличением неравенства в потреблении» [Krueger, Perri 2006: 163]. Впрочем, другие авторы с этим не согласны. Орацио Аттаназио, Эрик Херст и Луиджи Пистаферри думают, что «в США неравенство в уровне потребления в 1980-2010 гг. выросло почти на ту же величину, что и неравенство доходов» [Attanasio, Hurst, Pistaferri 2012].

Исследование неравенства в уровне потребления весьма ценно, но, как и в случае с неравенством доходов, наводит на ряд вопросов. Во-первых, что выявляется в ходе потребительских опросов? В этом случае мы наблюдаем не столько потребление, сколько потребительские расходы, что не одно и то же (как доказывает приведённый выше пример с недвижимостью, используемой самим её владельцем). Потребление превышает потребительские расходы; в иных случаях, например, когда семья приобретает товар длительного пользования, её расходы за период могут превышать потребление. (Относительно расходов на образование и медицинское обслуживание учёные применяют разные подходы.) Во-вторых, насколько точно измеряются потребительские расходы? Хорошо известно, что при опросах респонденты занижают уровень потребления некоторых товаров, таких как алкоголь и табак. А как насчёт общего уровня потребления? Ключевой вопрос: меняется ли с течением времени степень недооценки уровня неравенства потребления? Как отмечают Марк А. Агияр и Марк Бильс, если в США неравенство потребления растёт медленнее неравенства доходов, то зеркальным отображением этого процесса будет «увеличивающаяся разница в сбережениях в пользу домохозяйств с высоким уровнем доходов. Если судить по заявленным потребительским расходам, то выходит, что в США наиболее обеспеченная группа населения в 1980-2007 гг. повысила норму сбережений с 25 до 38\%, тогда как наименее обеспеченная группа в тот же период сохранила норму сбережений на прежнем уровне (примерно - 30\%)» [Aguiar, Bils 2011: 2]. Упомянутые авторы утверждают, что подразумеваемые нормы сбережений являются неправдоподобными. В самом деле, заявленные в ходе опросов совокупные потребительские расходы, по сравнению с их оценкой в статистике национального дохода, в процентном отношении сократились. Исследование, проведённое по заказу Федеральной резервной системы (ФРС), показало, что в 1992 г. - начале 2000-х гг. это соотношение снизилось примерно на 10 процентных пунктов. И хотя сегодня выявленный в ходе опросов уровень потребительских расходов остаётся стабильным (примерно 78\%), сказанное может частично объяснять разницу в результатах, по сравнению с более длительным периодом [Sabelhaus et al. 2012].

Следует задать вопрос и об охвате населения. Исследование, проведённое Крюгером и Перри (которые выявили сравнительно меньший рост неравенства в потреблении), ограничивалось узкой выборкой населения. Там отсутствовали все сельские домохозяйства, все домохозяйства, возглавляемые лицами моложе 21 года и старше 64 лет, все домохозяйства, чьи доходы (заработная плата плюс трансферты) были нулевыми, и все домохозяйства, зарплата которых была меньше половины официального минимума. Результаты этого исследования несопоставимы с показателями неравенства доходов, охватывающими всё население страны. Принимая в расчёт всё население США, Джонатан Фишер, Дэвид Джонсон и Тимоти Смидинг обнаружили, что «в 1985-2006 гг. темпы роста неравенства в доходах и в потреблении остаются примерно одинаковыми, но в период Великой рецессии (2006-2010 гг.) расходятся, причём в 2010 г. уровень неравенства в потреблении оказывается ниже, чем в 2006 г.» [Fisher, Johnson, Smeeding 2013: 187].

Выбор между оценкой неравенства по уровню потребления или по уровню доходов зависит от цели анализа. В случае оценки уровня бедности ответ связан с тем, какой из двух концепций мы придерживаемся. Предметом внимания первой концепции является уровень жизни; вторая концепция интересуется правом на минимальный объём ресурсов. Исторически сложилось так, что исследователи бедности приняли первую концепцию. Те, кого интересовал уровень доходов, исходили из того, что низкие доходы оставляют мало шансов для сбережений, так что доход служил надёжной основой для измерения потребления. Ещё в начале XX века Сибом Раунтри (Seebohm Rowntree), британский социолог (и по совмести- 
тельству изготовитель шоколада), сравнивая доходы разных домохозяйств, исходил из уровня бедности, достаточного «для получения минимума жизненных благ, необходимых для поддержания одной лишь физической работоспособности» [Rowntree 1922: 117]. Однако со временем обратил внимание на более широкое определение бедности, учитывающее возможность участия малоимущих в жизни общества, а вместе с тем и интерес к концепции минимальных прав на ресурсы, использование которых являлось бы предметом индивидуального выбора. Разницу между двумя подходами можно проиллюстрировать измерением уровня бедности мужчин и женщин. Подход, оперирующий уровнем жизни, допускает установление различных критериев бедности для мужчин и женщин на том основании, что женщины в среднем испытывают меньшие потребности в продуктах питания. Именно таким образом определялась официальная черта бедности в США в первые годы её существования. Черта бедности, которую в 1963 г. предложил Молли Оршански для городских жителей в возрасте до 65 лет, составляла 1650 дол. в год для мужчины и лишь 1525 дол. в год для женщины [Orshansky 1965: 28 (Table E, p. 28)]. Подход, исходящий из минимального права на ресурсы, делает такую дифференциацию неприемлемой.

Против использования потребительских расходов в качестве показателя бедности или неравенства можно выдвинуть то возражение, что расходы, как и доходы, являются не целью, а средством для её достижения. Вопиющее неравенство может возникнуть в процессе потребления, то есть при обращении денег в товары и услуги. Неравенством является неодинаковый доступ к товарам и услугам за счёт разницы в ценах: например, есть мнение, что «бедные платят больше», так как совершают покупки в ближайших магазинах, а не в пригородных супермаркетах. Владельцы доходных домов порой устанавливают в квартирах счётчики энергопотребления, действующие по принципу таксофона (в них вставляются монеты), из-за чего малообеспеченные жильцы вынуждены переплачивать за энергоносители. Неравенство может быть вызвано отсутствием доступа к товарам и услугам. По мере роста благосостояния местных сообществ магазины могут отказываться от завоза продукции дешёвых сортов или товаров среднего качества. В отдельных регионах бывают недоступны те или иные услуги - например, банковское сопровождение коммерческих сделок. Препятствием для получения банковских ссуд малоимущими становится предварительная оценка их кредитоспособности. Все эти вопросы требуют тщательного изучения, и лишь после этого мы сможем судить о меняющейся структуре неравенства в потреблении.

Соображения по поводу доступности товаров и услуг заставляют нас задуматься о распределении некоторых видов дефицитных товаров, или, как выразился лауреат Нобелевской премии по экономике Джеймс Тобин из Йельского университета, о введении «специфического эгалитаризма» (specific egalitarianism). Среди прочих благ, подлежащих «уравнительному» распределению, он называет жильё, продовольствие, образовательные и медицинские услуги [Tobin 1970: 264]22. В странах Европы подход к измерению бедности и социального отчуждения с 2009 г. включает критерий материальных лишений. Одним из трёх компонентов целевой программы по преодолению бедности и социального отчуждения в Европе на период до 2020 г. (Europe 2020) является показатель «суровых материальных лишений», определяемый по отсутствию четырёх базовых жизненных благ (из предписанных девяти). В число предписанных девяти благ входят, в частности, следующие: отсутствие задолженности по оплате жилья; возможность питаться блюдами из мяса, курицы или рыбы; поддержание приемлемой температуры в жилище [Fusco, Guio, Marlier 2010]. Интересное различие между списком Тобина и перечнем ЕС состоит в том, что первый включает образовательные и медицинские услуги, предоставление которых европейцы считают главнейшей обязанностью государства. Однако в верхней части шкалы доходов симптоматичным показателем возможности «добровольного отчуждения» служит право богачей отказаться от государственных услуг в пользу частного образования и здравоохранения.

22 Эссе лауреата Нобелевской премии Джеймса Тобина полезно прочесть и сегодня. Тобин, профессор экономики в Йельском университете, был приглашён на должность советника президента Дж. Ф. Кеннеди по экономическим вопросам. Сначала Тобин отказывался, называя себя «экономистом в башне из слоновой кости». «Это ничего, профессор, - ответил Кеннеди, - меня тоже считают президентом в башне из слоновой кости» [Obituary for James Tobin 2002]. 
Как полагает британский философ Брайан Бэрри, «если богачи считают возможным оградить себя от коллективной судьбы и откупиться от общих институтов, то это также является формой социальной изоляции» [Barry 1998: 8].

Многогранный характер потребления и вызываемые этим противоречивые суждения приводят к тому, что потребительские расходы в качестве индикатора неравенства не выглядят предпочтительнее показателей дохода. Эти последние я по-прежнему считаю индикатором потенциального контроля над ресурсами. В этом смысле апелляция к доходу означает признание того факта, что пользование ресурсами не сводится к одному лишь потреблению. При оценке неравенства нас интересует не только потребление богатых - сколь бы важным ни был этот фактор, - но власть и влияние, которые могут сопутствовать богатству. Власть и влияние могут распространяться на собственную семью (например, при передаче своего состояния наследникам) или - в более общем плане - на весь социум (такими способами, как контроль над СМИ или влияние на политические партии). Типичным примером служат благотворительные пожертвования. Бросив монетку в кружку для сбора пожертвований, мы не приобретаем особого влияния, тогда как создание благотворительных фондов способно глубоко воздействовать на жизнь людей, что наглядно продемонстрировал Билл Гейтс. Подобное воздействие может быть весьма полезным, но оно представляет собой осуществление власти, не поддающееся контролю путём количественной оценки потребления. Бесспорно, доход - это средство для достижения цели, однако в своих функциях он выходит далеко за рамки потребления.

\section{Кто и где представлен на шкале распределения доходов?}

Англичанка Барбара Вуттон, экономист и общественная активистка, рассказала, что одним из поводов, подвигнувших её на написание книги «The Social Foundations of Wage Policy» («Социальные основы политики заработной платы»), стало удивительное открытие. Оказалось, что слон, развлекавший посетителей в местном зоопарке, «зарабатывал» столько же, сколько она в качестве старшего преподавателя университета [Wootton 1955]. Я не уверен в релевантности этого конкретного сравнения, но нет сомнений в том, что всякий человек хотел бы знать, какова его позиция на шкале распределения доходов $^{23}$. Столь же мало сомнений в том, что многие люди (особенно находящиеся наверху пирамиды), полагают, что занимают на шкале доходов позицию ниже той, что принадлежит им в действительности. Чтобы отобразить распределение доходов, голландский экономист Ян Пен ввёл понятие «парад доходов». Однажды он спросил у врача, явно относившегося к $0,3 \%$ самых высокооплачиваемых специалистов, какой процент населения, по его мнению, находится выше его на шкале доходов. Тот подумал и ответил: 20\% [Pen 1971: 9]. Недавно подобный вопрос Полли Тойнби и Дэвид Уокер задали видным юристам и банкирам лондонского Сити, принадлежащим к 1\% самых высокооплачиваемых работников. Оценивая сумму доходов, требуемую для вхождения в верхние $10 \%$ богатейших людей, юристы и банкиры завысили её в четыре раза. Отвечая на вопрос о «пороге бедности», эта элитарная группа определила его на уровне, оказавшемся «чуть ниже валового среднего дохода, то есть они считали заработки рядовых граждан неким эквивалентом пособия по бедности» [Toynbee, Walker 2009: 25].

Даже при скромных темпах инфляции показатели распределения доходов быстро устаревают, но они могут разъяснить читателю, кто был на каком месте в 2013 г. Тогда Бюро переписи населения США определяло средний доход домохозяйства в 51939 дол. в год, а порог бедности для семьи из четырёх человек (ниже которого жило 14,5\% населения) составлял 23834 дол. (или 46\% от среднего дохода).

23 Есть интересные сайты, где можно, указав свой доход, определить своё место на шкале распределения доходов данной страны. Для ряда стран усилиями сообщества «Giving What You Can» («Отдавать то, что можешь») создан сайт (URL: https://www.givingwhatwecan.org/get-involved/how-rich-am-i). Есть сайт и для США (URL: www.whatsmypercent. com/). Для Великобритании усилиями Института финансовых исследований (Institute for Fiscal Studies) тоже создан сайт (URL: http://www.ifs.org.uk/wheredoyoufitin/). 
Эти цифры относятся к денежным доходам до уплаты налогов и не включают стоимость безналичной помощи, такой как продовольственные талоны. Двигаясь вверх по шкале доходов, мы узнаём от Бюро переписи населения, что для включения домохозяйства в богатейшие $10 \%$ оно должно иметь доход в 150 тыс. дол., то есть примерно втрое выше среднего показателя. Эммануэль Саез из Бёркли, основываясь на несколько ином определении, предполагает, что «богатейший процент» начинается с доходов порядка 400 тыс. дол. ${ }^{24}$.

В Великобритании официальные данные говорят о том, что средний располагаемый доход домохозяйств с поправкой на размер и состав семьи в 2012-2013 гг. составлял 15300 фунтов стерлингов в год для одного человека, 22950 фунтов стерлингов для семейной пары и 32125 фунтов стерлингов в год для супругов и двух детей. (При сравнении с цифрами по США следует помнить, что в случае Великобритании прямые налоги были вычтены, в отличие от США.) Порог бедности был установлен в размере $60 \%$ от среднего уровня, то есть 9180 фунтов стерлингов в год на одного человека. Верхняя часть шкалы доходов в Великобритании не столь растянута, так что доход, вдвое превышающий средний уровень (64 250 фунтов стерлингов в год для супругов и двух детей), подводит домохозяйство к порогу вхождения в богатейшие $10 \%{ }^{25}$. До сих пор мы говорили о вертикальном измерении неравенства (между богатыми и бедными), но существуют и важные горизонтальные параметры. Коэффициент Джини и понятие «богатейший процент населения» - категории анонимные, но нас интересует то, каково неравенство доходов у социальных групп, различающихся, например, по гендерному признаку, месту жительства или этнической принадлежности ${ }^{26}$. Возможно, следует учитывать различия в потребностях. Например, приведённые выше показатели неравенства доходов не учитывают географических различий в ценах. Так, стоимость жизни в Бостоне оценивается в 132,5 балла, тогда как в городе Топика, штат Канзас, она составляет лишь 91,8 балла ${ }^{27}$. Ещё одно важное отличие состоит в том, что потребности зависят от наличия у человека инвалидности; есть ценные исследования, доказывающие необходимость включить эти потребности в шкалу эквивалентности, используемую для расчёта дохода, скорректированного с учётом инвалидности. В случае Великобритании Асгар Заиди и Таня Бурчард показывают, как отказ от учёта затрат, вызванных инвалидностью, существенно занижает планку бедности для людей с ограниченными возможностями. Ниже мы рассмотрим бедность в трёх его горизонтальных измерениях: пол, поколение и планетарный масштаб.

\section{Пол}

На приведённых выше рисунках, отражающих дисперсию доходов, не проводилось различий между доходами мужчин и женщин. Эти рисунки ничего не говорили нам о разнице в оплате труда по гендерному признаку. Для Америки данные Бюро переписи населения США показывают соотношение среднего (медианного) заработка женщин и (или) мужчин, занятых на постоянной основе полный рабочий

24 См. источники для рис. 1.1.

25 См. сайт Института фискальных исследований; см. также источники для рис. 1.2.

26 Разница доходов этнических групп является важной темой, в которую я здесь не углубляюсь. Если взять максимальные доходы, то в 2013 г. в США совокупный денежный доход в размере не менее 200 тыс. дол. в год (без учёта налогов и льгот в натуральной форме) получали 5,7\% белых семей. Для афроамериканских и испаноязычных семей соответствующие цифры составляли лишь треть от этой доли (1,8\%). Зато среди американских семей азиатского происхождения доля зажиточных была выше (8,5\%). Источником этих данных является: [U.S. Bureau of the Census 2013: Table A-1]. B Великобритании в 2010-2013 гг. (в среднем за три года) доходом не менее 52 тыс. фунтов стерлингов в год располагали $22 \%$ семей. Среди иммигрантов из Азии и британских подданных азиатского происхождения цифра была выше: $25 \%$. Зато у чернокожих британцев, у выходцев из Африки, из стран Карибского бассейна и других стран с населением разного происхождения эта доля составляла 16\%, а у выходцев из Бангладеш — лишь 11\%. Источником этих цифр является: [Family Resources Survey (FRS) 2012: Table 2.6].

27 URL: http://www.infoplease.com/business/economy/cost-living-index-us-cities.html (Дата обращения: 1 января 2015 г.). 
день. В 1960 г. это соотношение составляло 60\%, а к 2013 г. возросло до 78\%. Это положительный сдвиг, но ситуация по-прежнему такова, что мужчины зарабатывают в среднем на одну пятую больше, чем женщины. Кроме того, тренд к росту соотношения не является устойчивым. В 1960-1980 гг. соотношение было стабильным, а в последующие два десятилетия увеличилось. С 2000 г. изменения были незначительными [U.S. Bureau of the Census 2013: Table A-4]. В обзоре данных по восьми странам членам ОЭСР Софи Понтиё и Доминик Мёрс отмечают, что «с конца 1990-х гг. гендерный разрыв в зарплатах сокращается медленнее (за исключением Великобритании и Японии, где сокращение продолжалось в прежнем темпе) или стагнирует, а в отдельных странах (как в Италии) даже увеличивается» [Ponthieux, Meurs 2014: 1008].

При рассмотрении динамики гендерного разрыва в доходах нам необходимо - как и с распределением доходов в целом - отличать неравенство, вызванное такими характеристиками, как уровень образования (способный оправдать разницу в оплате труда), от неравенства, отражающего дискриминацию. Исторически сложилось так, что основным фактором общего сокращения гендерного разрыва в заработной плате было повышение уровня образования женщин. В США процент лиц, окончивших колледж, среди женщин составлял в 1950 г. примерно половину от доли мужчин (любопытно, что это явление относится лишь к 1930-м гг.; для когорт рождения 1910 г. и ранее эта разница была невелика). После 1950 г. доля женщин - выпускниц колледжей начала расти, и сегодня женщины составляют большинство выпускников колледжей США. Подобная трансформация гендерного разрыва в уровне образования наблюдается в большинстве стран-членов ОЭСР. Сегодня по этому показателю женщины опережают мужчин в 29 из 32 стран - членов ОЭСР ${ }^{28}$. Дорис Вайксельбаумер и Рудольф ВинтерЭмбер, проанализировав свыше 1500 исследований гендерного разрыва в заработной плате (за 1960 1990-е гг; охватившие 63 страны), суммировали роль образования и других характеристик, значимых для рынка труда. Они делают такой вывод: «По большей части сокращение гендерного разрыва объясняется улучшением положения женщин на рынке труда, достигнутым ростом уровня образования, профессиональной подготовкой и усердием в работе. Анализ публикуемых оценок дискриминационного (или ничем необъяснимого) компонента гендерного разрыва в оплате труда даёт менее оптимистичную перспективу: со временем сокращение разрыва не происходит» [Weichselbaumer, Winter-Ebmer 2005: 508]. Чуть более оптимистичную картину даёт стандартизация отбора данных и упразднение различий в статистических методах. Однако и в этом случае для сокращения гендерного разрыва, приписываемого дискриминации, на 10 процентных пунктов потребуется около 60 лет. Таким образом, гендерное неравенство остаётся важным поводом для беспокойства.

\section{Временной фактор и разница между поколениями}

Рисунки 1.1 и 1.2 отражают для США и Великобритании последовательные ряды «моментальных снимков» с разъяснением конкретного положения, в котором на указанный промежуток времени находилось всё население обеих стран. В результате мы не видим всего фильма целиком и не знаем, сохранили ли люди, находившиеся в верхней части шкалы доходов, свои позиции на следующий год. Не знаем мы и того, скольким малоимущим семьям удалось в следующем году вырваться из бедности. А это важно знать по трём причинам. Во-первых, существует текущая (происходящая из года в год) мобильность, и вполне возможно, что наблюдаемый рост неравенства связан с повышенной волатильностью. Именно этим специалисты по макроэкономике обычно объясняют рост доли максимальных доходов. В Великобритании показатель мобильности доходов исследовал Стивен Дженкинс, обнаруживший значительную степень мобильности доходов в наблюдаемом году относительно последующего года. Однако затем он внёс коррективы в своё открытие, заявив, что по большей части эта мобильность является не долгосроч-

28 Цифры гендерного состава студентов американских колледжей взяты из публикации: [Goldin, Katz, Kuziemko 2006]. Статистика по странам ОЭСР взята из работы: [Ponthieux, Meurs 2014]. 
ной, а краткосрочной. Дженкинс дал описание соответствующего процесса: «Доход каждого человека колеблется вокруг относительно стабильного долгосрочного среднего значения; это последнее служит фиксатором на шкале доходов, к которому люди как бы привязаны неким “резиновым жгутом”. Время от времени они могут отходить от фиксатора, но не слишком далеко, поскольку их удерживает этот "резиновый жгут". Как правило, они возвращаются назад, ближе к фиксатору» [Jenkins 2011: 360-361]. Выросла ли мобильность? В США Питер Готтшальк и Роберт Моффитт обнаружили, что в конце 1970-х и начале 1980-х гг. увеличение временных колебаний в доходах могло составлять до половины возросшей дисперсии, но затем эффект выровнялся [Gottschalk, Moffitt 2009]. В отношении 1970-2004 гг. Войцех Копчук, Эммануэль Саез и Джей Сонг пришли к выводу, что практически всё увеличение дисперсии доходов было обусловлено увеличением дисперсии постоянных доходов. Они обнаружили, что «мобильность в верхней части шкалы распределения доходов является стабильной и не смягчает резкого увеличения годовой концентрации доходов с 1970 г.» [Kopczuk, Saez, Song 2010: 91]. Это согласуется с выводом Готтшалька и Моффита о том, что рост нестабильности доходов сконцентрирован в группе наименее квалифицированных работников и лишь опосредованно связан с увеличением доли доходов верхней децили (см. рис. 1.1). Дженкинс выяснил, что в Великобритании с начала 1990-х до середины 2000-х гг. временная волатильность изменилась несильно. Представляется, что увеличение волатильности (по крайней мере, в США и Великобритании) - это лишь небольшая часть нашего сюжета.

Вторая причина, по которой необходимо анализировать жизненный цикл человека, состоит в том, что в разные периоды его карьеры с размерами дохода происходят вполне предсказуемые перемены. Доходы многих людей представляют собой широкую волнообразную кривую, возрастающую по мере карьерного роста и нисходящую в связи с выходом на пенсию и расходованием сделанных накоплений. Если в демографической структуре произошёл сдвиг, то систематические различия, возникающие в ходе жизненного цикла, объясняют часть наблюдаемого роста неравенства. Сюда же можно отнести перемены в составе семьи (в частности, увеличение доли семей с одним родителем). В 1960 г., по данным Бюро переписи населения США, в семьях с одним родителем жили 9\% детей; к 2010 г. эта доля возросла до 27\%. В Великобритании сегодня наблюдается похожая тенденция: каждый четвёртый ребёнок живёт в неполной семье. В США Ребекка Бланк, специалист по экономике труда и бывший член кабинета президента Б. Обамы, заинтересовалась тем, насколько изменения в демографической и семейной структуре могли повлиять на рост коэффициента Джини в 1979-2007 гг. Она обнаружила, что если демографические сдвиги и сыграли свою роль, то их вклад был невелик - порядка 1,25 процентного пункта [Blank 2011: 93]. Для Великобритании ранее Дженкинс оценил вклад демографических сдвигов, происходивших в 1971-1986 гг., как весьма скромный. Несомненно, при выработке политики важно учитывать все изменения демографической и семейной структуры, но они опять-таки мало содействуют объяснению растущего неравенства.

Третья причина отслеживать жизненные циклы людей - возможность значительного неравенства между поколениями. Если, как это было в прошлом, реальные доходы с течением времени возрастают, то люди последующих поколений на протяжении жизни получают более высокие доходы. Подобный рост заложен в стандартный подход к оценке инвестиционных решений государства. Когда правительство рассматривает некий долгосрочный проект или взвешивает выгоды от смягчения климата, оно применяет социальную ставку дисконтирования, состоящую из двух компонентов: (1) понижающего коэффициента, отражающего чистую протяжённость во времени; (2) коэффициента, отражающего ожидание лучших условий жизни для будущих поколений ${ }^{29}$. Иначе говоря, к доходам будущих поколений применяется более низкая оценка, как более низкая оценка применяется к доходам зажиточных групп населения при определении неравенства в конкретный момент времени. Впрочем, сегодня по-

29 Математическая формула имеет следующий вид: $d+e g$, где $d-$ чистая ставка дисконтирования; $e-$ эластичность предельной величины потребления; $g$ - темп роста объёма потребления на душу населения. 
добные ожидания могут и не оправдаться. Если теперь, когда мы стремимся обрести устойчивый путь развития, можно ожидать замедления (или даже прекращения) роста средних доходов, то нам не следует применять такого рода дисконтирование к будущим поколениям. Мы не вправе утверждать, что они будут жить лучше, чем мы живём сегодня, поэтому не должны считать, что они меньше заслуживают предпочтения (а ведь к этому и сводится дисконтирование). Возможно, что они будут жить не лучше нас (может статься, даже хуже). Вопрос о справедливости в отношениях между поколениями имеет сегодня больший приоритет, чем когда мы полагали, считая, что жизнь может только улучшаться. Этот вопрос должен стать одним из критериев, по которым мы оцениваем выбор политических мер по сокращению текущего неравенства доходов.

\section{Глобальное неравенство}

В общем неравенстве жителей планеты отражается совокупный эффект неравенства в отдельных странах и неравенства, существующего между странами. С этой точки зрения, простая история глобального неравенства за последние сто лет сводится к тому, что в начальный период неравенство в богатых странах сокращалось, а между странами увеличивалось. Теперь же наступил период, когда неравенство в богатых странах растёт, а между странами сокращается. Если график неравенства внутри стран имеет U-образную форму, то неравенство между странами выглядит как $\cap$-образная кривая.

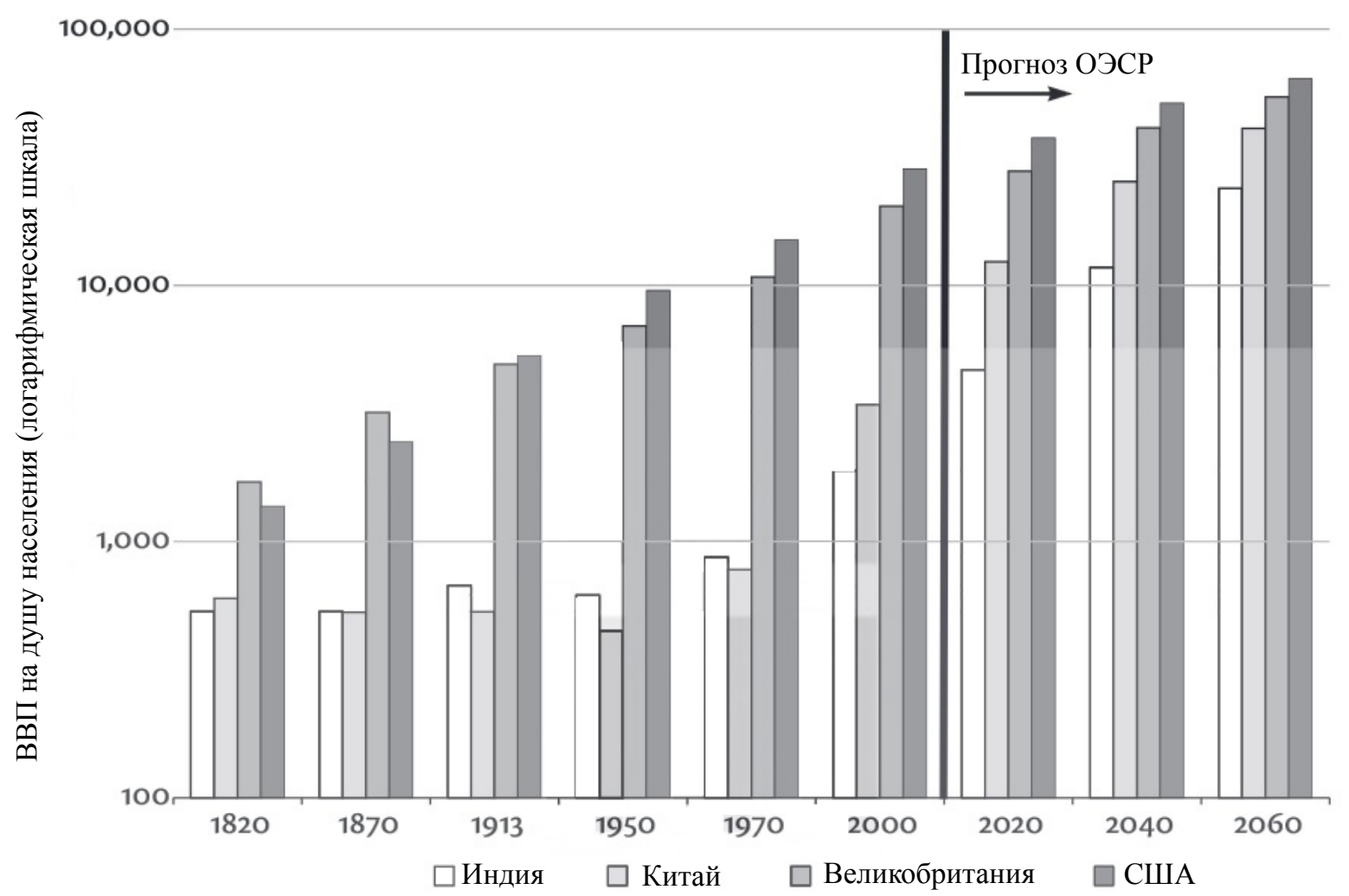

Источники: Данные за 2000 г. и за предыдущие периоды взяты с сайта: Angus Maddison, Historical Statistics of the World Economy, GDP measured at 1990 PPPs (URL: http://www.ggdc.net/maddison/oriindex.htm). Прогноз на 2020 г. и позднейшие периоды: Long-term Baseline Projections from OECD Economic Outlook No. 95, May 2014, Dataset, GDP at 2005 US\$ PPPs. Цифровые ряды по Великобритании и США встроены в общую картину с помощью данных Ангуса Мэддисона за 2008 г. и данных по странам ОЭСР за 2010 г; цифры по Китаю и Индии, как представляется, в корректировке не нуждаются.

Примечание: В 1820 г. ВВП на душу населения по ППС (паритет покупательной способности, который рассчитывается как обменный курс с поправкой на разницу в покупательной способности) составлял 533 дол. в Индии, 600 дол. в Китае, 1376 дол. в США и 1706 дол. в Великобритании.

Рис. 1.6. Глобальная дивергенция, затем — конвергенция: ВВП на душу населения, 1820-2060 гг. 
Эта П-образная кривая - расхождение между странами с последующим их сближением - подтверждается на примере четырёх стран (см. рис. 1.6), где показаны абсолютные различия в национальном доходе (или ВВП) на душу населения в Индии, Китае, Великобритании и США, как они - эти различия - возникли исторически и как могут развиваться в соответствии с прогнозами ОЭСР. В каждом случае национальный доход выражен в терминах покупательной способности, учитывающих происходящий со временем рост стоимости жизни, а также разницу в покупательной способности валюты в разных странах (на доллар в Дели можно купить больше товаров, чем в Нью-Йорке). Нет нужды подчёркивать, что такие сравнения во времени и пространстве являются лишь приблизительными, но для отображения общей картины они достаточны. В 1820-1970 гг. в мире увеличился разрыв между Индией и Китаем, с одной стороны, и США с Великобританией - с другой. За это время доход на душу населения в США вырос более чем в 10 раз; в Великобритании за тот же период этот показатель вырос гораздо меньше. Хотя изначально англичане заметно опережали американцев, со временем США вырвались в лидеры. Начиная с 1970-х гг. Индия и Китай сокращают разрыв в доходах с развитыми странами, и, по прогнозам ОЭСР, эта тенденция продолжится до конца нынешнего столетия.

Как обычно полагают, $\bigcap$-образная кривая распределения доходов между странами внушает надежду на то, что со временем глобальное распределение доходов станет более равномерным. Однако есть две причины, внушающие беспокойство. Во-первых, если разрыв между странами в относительном выражении сокращается, то абсолютная разница в их покупательной способности продолжает увеличиваться. Возможно, в процентном отношении экономика Китая растёт быстрее, но её подъем идёт от гораздо меньшей базы. По прогнозам ОЭСР, до 2057 г. абсолютная разница в доходе на душу населения между Китаем и США будет увеличиваться. Во-вторых, если Китай и Индия продолжают расти быстро, то другие развивающиеся страны показывают гораздо меньшие темпы роста. Именно поэтому, нацеливая большинство предложений на борьбу с неравенством внутри государства, в главе 8 настоящей книги я рассматриваю глобальную ответственность стран - членов ОЭСР за содействие процессу перераспределения доходов в международном масштабе.

\section{Литература}

Aaberge R., Langørgen A., Lindgren P. 2013. The Distributional Impact of Public Services in European Countries. Statistics Norway Research Department Discussion Paper. 746. URL: http://www.ssb.no/en/ forskning/discussion-papers/_attachment/123883?_ts=13f50d54ab8

Abel-Smith B., Townsend P. 1965. The Poor and the Poorest. London: G. Bell.

Aguiar M. A., Bils M. 2011 . Has Consumption Inequality Mirrored Income Inequality? NBER Working Paper. No. 16807. URL: http://www.nber.org/papers/w16807.pdf

Atkinson A. B. 1969. Poverty in Britain and the Reform of Social Security. Cambridge: Cambridge University Press.

Atkinson A. B. 1997. Bringing Income Distribution in from the Cold. Economic Journal. 107: 297-321.

Atkinson A. B. 2008. The Changing Distribution of Earnings in OECD Countries. Oxford: Oxford University Press.

Atkinson A. B., Brandolini A. 2010. On Analysing the World Distribution of Income. World Bank Economic Review. 24: 1-17. 
Atkinson A. B., Brandolini A. 2015. Unveiling the Ethics behind Inequality Measurement: Dalton's Contribution to Economics. Economic Journal. 125: 209-234.

Atkinson A. B. et al. 2002. Social Indicators. Oxford: OxfordUniversity Press.

Atkinson A. B., Marlier E. 2010. Living Conditions in Europe and the Europe 2020 Agenda. In: Atkinson A. B., Marlier E. (eds) Income and Living Conditions in Europe. Luxembourg: Publications Office of the European Union; 21-35.

Atkinson A. B., Micklewright J. 1992. Economic Transformation in Eastern Europe and the Distribution of Income. Cambridge: Cambridge University Press.

Atkinson A. B., Morelli S. 2014. Chartbook of Economic Inequality. ECINEQ Working Papers. No. 324. URL: http://www.chartbookofeconomicinequality.com/

Attanasio O., Hurst E., Pistaferri L. 2012. The Evolution of Income, Consumption, and Leisure Inequality in the US, 1980-2010. NBER Working Paper No. 17982. April. URL: http://papers.nber.org/tmp/69610w17982.pdf

Auten G., Gee G., Turner N. 2013. Income Inequality, Mobility, and Turnover at the Top in the US, 1987-2010. American Economic Review. 103: 168-172.

Barry B. 1998. Social Exclusion, Social Isolation and the Distribution of Income. CASE Paper. 12. London: Centre for Analysis of Social Exclusion, London School of Economics.

Blank R. M. 2011. Changing Inequality. Berkeley: University of California Press.

Brandolini A., Smeeding T. M. 2011. Income Inequality in Richer and OECD Countries. In: Salverda N., Smeeding T. M. (eds) The Oxford Handbook of Economic Inequality. Oxford: Oxford University Press; $71-100$.

Brian A.-S., Townsend P. 1965. The Poor and the Poorest. London: G. Bell.

Budd E. C. 1970. Postwar Changes in the Size Distribution of Income in the U.S. American Economic Review, Papers and Proceedings. 60: 247-260.

Dalton H. 1920a. The Measurement of the Inequality of Incomes. Economic Journal.30:348-361.

Dalton H. 1920b. Some Aspects of the Inequality of Incomes in Modern Communities. London: Routledge.

Debreu G. 1959. Theory of Value. New York: John Wiley.

Donne J. 1962. Meditations XVII, Devotions upon Emergent Occasions. London: Nonesuch Press.

Eliot G. 1861.Silas Marner: The WeaverofRaveloe. Edinburgh: William Blackwood.

Fair R. C. 1971. The Optimal Distribution of Income. Quarterly Journalof Economics. 85: 551-579.

Family Resources Survey (FRS) United Kingdom, 2012/13. 2014. London: Department of Work and Pensions. 
Feldstein M. S. 2005. Rethinking Social Insurance. American Economic Review. 95: 1-24.

Fisher G. 1970. Estimates of the Poverty Population under the Current Official Definition for Years before 1959. Mmimeograph, Office of the Assistant Secretary for Planning and Evaluation, U.S. Department of Health and Human Services.

Fisher J. D., Johnson D. S., Smeeding T. M. 2013. Measuring the Trends in Inequality of Individuals and Families: Income and Consumption. American Economic Review, Papers and Proceedings 103: 184-188.

Frazer H. et al. 2014. Putting the Fight against Poverty and Social Exclusion at the Heart of the EU Agenda: A Contribution to the Mid-Term Review ofthe Europe 2020 Strategy. OSE Paper 15. Brussels: Observatoire Social Européen.

Friedman M., Kuznets S. 1945. Income from Independent Professional Practice. New York: National Bureau of Economic Research.

Fusco A., Guio A.-C., Marlier E. 2010. Characterizing the Income Poor and the Materially Deprived in European Countries. In: Atkinson A., Marlier E. (eds) Income and Living Conditions in Europe. Luxembourg: Publications Office of the European Union; 133-153.

Gates B. 2014. Why Inequality Matters, Review of Piketty «Capital in the Twenty-First Century». URL: http:// www.gatesnotes.com/Books/Why-Inequality-Matters-Capital-in-21st-Century-Review

Gini C. 1912. Variabilità e Mutabilità. Bologna: Paolo Cuppini.

Goldin C., Katz L. F., Kuziemko I. 2006. The Homecoming of American CollegeWomen: The Reversal of the College Gender Gap. Journal of Economic Perspectives. 20 (4): 133-156.

Gottschalk P., Moffitt R. 2009. The Rising Instability of U.S. Earnings. Journal of Economic Perspectives. 23: $3-24$.

Jenkins S. P. 2011. Changing Fortunes. Oxford: Oxford University Press.

Jenkins S. P., Kerm P. van. 2009. The Measurement of Economic Inequality. In: Salverda W., Nolan B., Smeeding T. M. (eds) The Oxford Handbook of Economic Inequality. Oxford: Oxford University Press; $40-67$.

Jorgenson D. 1998. Did We Lose the War on Poverty? Journal of Economic Perspectives. 12: 79-96.

Kanbur R., WagstaffA. 2014. How Useful Is Inequality of Opportunity asa Policy Construct? ECINEQ Working Paper. 338: 1-18.

Karoly L. A. 1994. The Trend in Inequality among Families, Individuals, and Workers in the United States: A Twenty-Five Year Perspective. In: Danziger S., Gottschalk P. (eds) Uneven Tides. New York: Russell Sage Foundation; 19-97.

Kopczuk W., Saez E., Song J. 2010. Earnings Inequality and Mobility in the United States: Evidence from Social Security Data since 1937. Quarterly Journal of Economics. 125: 91-128. 
Krueger D., Perri F. 2006. Does Income Inequality Lead to Consumption Inequality? Review of Economic Studies. 73: 163-193.

Lucas R. E. 2003. The Industrial Revolution: Past and Future. In: The Region, 2003 Annual Report of the Federal Reserve Bank of Minneapolis. Minneapolis: Federal Reserve Bank; 5-20.

Mankiw N. G. 2007. Principles of Microeconomics. 7th ed. New York: Worth.

Mankiw N. G. 2014. Essentials of Economics. 7th ed. New York: Worth.

McCarty N., Poole K. T., RosenthalH. 2006. Polarized America: The Dance of Ideology and Unequal Riches. Cambridge, MA: MIT Press.

Meyer B. D., Sullivan J. X. 2012. Winning the War: Poverty from the Great Society to the Great Recession. Brookings Papers on Economic Activity (Fall): 133-200. URL: https:/www.brookings.edu/bpea-articles/ winning-the-war-poverty-from-the-great-society-to-the-great-recession/

Miller H. P. 1966. Income Distribution in the United States. Washington, DC: Bureau of the Census.

Morelli S., Smeeding T. M., Thompson J. 2014. Post-1970 Trends in Within-Country Inequality and Poverty. In: Atkinson A., Bourguignon F. (eds) Handbook of Income Distribution. Vol. 2. Amsterdam: North Holland; 593-696.

Obituary for James Tobin. 2002. Yale Bulletin and Calendar. 30 (22). 15 March.

OECD. 2011. Divided We Stand: Why Inequality Keeps Rising. Paris: OECD.

Orshansky M. 1965. Counting the Poor: Another Look at the Poverty Profile. Social Security Bulletin. 28: 3-29.

Pen J. 1971. Income Distribution. London: Allen Lane.

Pickett K., Wilkinson R. 2010. The Spirit Level. Rev. ed. London: Penguin.

Piketty T. 2014. Capital in the Twenty-First Century. Cambridge, MA: Harvard University Press.

Piketty T., Saez E. 2003. Income Inequality in the United States, 1913-1998. Quarterly Journal of Economics. 118: 1-39.

Plato. 1960. The Laws. V. 744e. New York: Dutton.

Ponthieux S., Meurs D. 2014. Gender Inequality. In: Atkinson A,Bourguignon F. (eds) Handbook of Income Distribution. Vol. 2A. Amsterdam: North Holland; 981-1145.

Rawls J. 1971. A Theory of Justice. Cambridge, MA: Harvard University Press.

Roemer J. 1998. Equality of Opportunity. Cambridge, MA: Harvard University Press.

Rowntree B. S. 1922 (1901) Poverty: A Study of Town Life. London: Longmans, Green and Co. 
The Royal Commission on the Distribution of Income and Wealth. 1979. Report No. 7, Fourth Report on the Standing Reference, Cmnd. 7595. London: HMSO.

Sabelhaus J. et al. 2012. Is the Consumer Expenditure Survey Representative by Income? Finance and Economics Discussion Series, Divisions of Research \& Statistics and Monetary Affairs. Washington, D.C.: Federal Reserve Board, URL: https://www.federalreserve.gov/pubs/feds/2012/201236/201236pap.pdf

Sandmo A. 2015. The Principal Problem in Political Economy: Income Distribution in the History of Economic Thought. In: Atkinson A. B., Bourguignon F. (eds) Handbook of Income Distribution. Vol. 2 A. Amsterdam: Elsevier; 3-65.

Sen A. 1973. On Economic Inequality. Oxford: Clarendon Press.

Sen A. 1999. Development as Freedom. Oxford: Oxford University Press.

Sen A. 2009. The Idea of Justice. London: Allen Lane.

Smith A. 1903 (1776). An Inquiry into the Nature and Causes of the Wealth of Nations. London: Routledge.

Social Protection Committee. 2014. Social Europe: Many Ways, One Objective. Luxembourg: Publications Office of the European Union.

Solow R. M. 1960. Income Inequality since the War. In: Freeman R. E. (ed.) Postwar Economic Trends in the United States. New York: Harper and Brothers; 91-138.

Solow R. M. 2003. Dumb and Dumber in Macroeconomics. URL: https://www0.gsb.columbia.edu/ faculty/jstiglitz/festschrift/ Papers/Stig-Solow.pdf.

Stiglitz J. E. 2012. The Price of Inequality. London: Allen Lane.

Tawney R. H. 1913. Poverty as an Industrial Problem. In: Memoranda on the Problems of Poverty. London: William Morris Press.

Tawney R. 1961 (1931) Equality. London: Allen and Unwin.

Tobin J. 1970. On Limiting the Domain of Inequality. Journal of Law and Economics. 13:263-277.

Toynbee P., Walker D. 2009. Unjust Rewards. London: Granta.

U.S. Bureau of the Census. 2014. Income, Poverty, and Health Insurance Coverage in the United States: 2013. Current Population Report. Washington, D.C.: U.S. Bureau of the Census.

U.S. Bureau of the Census. 2014. Income and Poverty in the United States: 2013. Annual Social and Economic Supplement to the Current Population Survey. Washington, D.C.: U.S. Bureau of the Census. URL: http:// www.census.gov/content/dam/Census/library/publications/2014/demo/p60-249.pdf

Weichselbaumer D., Winter-Ebmer R. 2005. A Meta-Analysis of the International Gender Wage Gap. Journal of Economic Surveys. 19: 479-511. 
Wootton B. 1955. The Social Foundations of Wage Policy. London: Allen \& Unwin.

World Top Incomes Database (WTID). URL: http://topincomes.g-mond.parisschoolofeconomics.eu/ 


\title{
BEYOND BORDERS
}

\section{Anthony B. Atkinson \\ Inequality: What Can be Done?}

\begin{abstract}
ATKINSON, Anthony B. (Sir) (1944-2017) - an academic economist particularly concerned with issues of social justice and the design of public policy. Sir Antony Atkinson was Centennial Professor at the London School of Economics and Fellow of Nuffield College, Oxford.
\end{abstract}

\begin{abstract}
In this book addressing how best to reduce contemporary large-scale income inequality, Prof. Atkinson considers economic inequality from a new perspective, drawing on extensive historical data covering more than a century of evolution in modern societies.

In the first of the book's three parts, the author explains his research motivation and poses the following questions. What does inequality mean? To what extent is it expanding today? Has history ever witnessed periods of declining inequality? How can economic theory explain inequality? The second part of the book is devoted to specific political and economic policies designed to reduce inequality. In the third part, the author assesses the
\end{abstract} extent to which the policies he proposes can be considered realistic, discussing the pros and cons of enacting and implementing them.

The Journal of Economic Sociology publishes the first chapter "Setting the Scene," which puts readers in the picture by discussing the notion of inequality and its extent. Demonstrating the term's multiplicity of meanings, Atkinson argues that all questions concerning its main dimensions should be answered before searching for its foundations.

Keywords: economic inequality; income distribution; social justice; poverty; consumption; household.

\section{References}

Aaberge R., Langørgen A., Lindgren P. (2013) The Distributional Impact of Public Services in European Countries. Statistics Norway Research Department Discussion Paper 746. Available at: http://www.ssb. no/en/forskning/ discussion-papers/_attachment/123883?_ts=13f50d54ab8 (accessed 15 March 2017).

Abel-Smith B., Townsend P. (1965) The Poor and the Poorest, London: G. Bell.

Aguiar M. A., Bils M. (2011) Has Consumption Inequality Mirrored Income Inequality? NBER Working Paper No. 16807. Available at: http://www.nber.org/papers/w16807.pdf (accessed 15 March 2017).

Atkinson A. B. (1969) Poverty in Britain and the Reform of Social Security, Cambridge: Cambridge University Press.

Atkinson A. B. (1997) Bringing Income Distribution in from the Cold. Economic Journal, no 107, pp. 297321.

Atkinson A. B. (2008) The Changing Distribution of Earnings in OECD Countries, Oxford: Oxford University Press. 
Atkinson A. B., Brandolini A. (2010) On Analysing the World Distribution of Income. World Bank Economic Review, no 24, pp. 1-17.

Atkinson A. B., Brandolini A. (2015) Unveiling the Ethics behind Inequality Measurement: Dalton's Contribution to Economics. Economic Journal, no 125, pp. 209-234.

Atkinson A. B., Cantillon B., Marlier E., Nolan B. (2002) Social Indicators, Oxford: Oxford University Press.

Atkinson A. B., Marlier E. (2010) Living Conditions in Europe and the Europe 2020 Agenda. Income and Living Conditions in Europe (eds. A. B. Atkinson, F. Marlier), Luxembourg: Publications Office of the European Union, pp. 21-35.

Atkinson A. B., Micklewright J. (1992) Economic Transformation in Eastern Europe and the Distribution of Income, Cambridge: Cambridge University Press.

Atkinson A. B., Morelli S. (2014) Chartbook of Economic Inequality. ECINEQ Working Papers, no 324. Available at: http://www.chartbookofeconomicinequality.com/ (accessed 21 March 2017).

Attanasio O., Hurst E., Pistaferri L. (2012) The Evolution of Income, Consumption, and Leisure Inequality in the US, 1980-2010. NBER Working Paper, no 17982 (April). Available at: http://papers.nber.org/ tmp/69610-w17982.pdf (accessed 15 March 2017).

Auten G., Gee G., Turner N. (2013) Income Inequality, Mobility, and Turnover at the Top in the US, 19872010. American Economic Review, no 103, pp. 168-172.

Barry B. (1998) Social Exclusion, Social Isolation and the Distribution of Income. CASE Paper, no 12, London: Centre for Analysis of Social Exclusion, London School of Economics.

Blank R. M. (2011) Changing Inequality, Berkeley: University of California Press.

Brandolini A., Smeeding T. M. (2011) Income Inequality in Richer and OECD Countries. The Oxford Handbook of Economic Inequality (eds. N. Salverda, T. M. Smeeding), Oxford: Oxford University Press, pp. 71-100.

Brian A.-S., Townsend P. (1965) The Poor and the Poorest, London: G. Bell.

Budd E. C. (1970) Postwar Changes in the Size Distribution of Income in the U.S. American Economic Review, Papers and Proceedings, no 60, pp. 247-260.

Dalton H. (1920a) The Measurement of the Inequality of Incomes. Economic Journal, no 30, pp. 348 361.

Dalton H. (1920b) Some Aspects of the Inequality of Incomes in Modern Communities, London: Routledge.

Debreu G. (1959) Theory of Value, New York: John Wiley.

Donne J. (1962) Meditations XVII, Devotions upon Emergent Occasions, London: Nonesuch Press. 
Eliot G. (1861) Silas Marner: The Weaver ofRaveloe, Edinburgh: William Blackwood.

Fair R. C. (1971) The Optimal Distribution of Income. Quarterly Journalof Economics, no 85, pp. 551-579.

Family Resources Survey(FRS) United Kingdom, 2012/13. (2014) London: Department of Work and Pensions.

Feldstein M. S. (2005) Rethinking Social Insurance. American Economic Review, no 95, pp. 1-24.

Fisher G. (1970) Estimates of the Poverty Population under the Current Official Definition for Years before 1959. Mimeograph, Office of the Assistant Secretary for Planning and Evaluation, U.S. Department of Health and Human Services.

Fisher J. D., Johnson D. S., Smeeding T. M. (2013) Measuring the Trends in Inequality of Individuals and Families: Income and Consumption. American Economic Review, Papers and Proceedings, no 103, pp. 184-188.

Frazer H., Guio A.-C., Marlier E., Vanhercke B., Ward T. (2014) Putting the Fight against Poverty and Social Exclusion at the Heart of the EU Agenda: A Contribution to the Mid-Term Review of the Europe 2020 Strategy. OSE Paper, no 15, Brussels: Observatoire Social Européen.

Friedman M., Kuznets S. (1945) Income from Independent Professional Practice, New York: National Bureau of Economic Research.

Fusco A., Guio A.-C., Marlier E. (2010) Characterizing the Income Poor and the Materially Deprived in European Countries. Income and Living Conditions in Europe (eds. A. Atkinson, E. Marlier), Luxembourg: Publications Office of the European Union, pp. 133-153.

Gates B. (2014) Why Inequality Matters, Review of Piketty Capital in the Twenty-First Century. Available at: http://www.gatesnotes.com/Books/Why-Inequality-Matters-Capital-in-21st-Century-Review (accessed 15 March 2017).

Gini C. (1912) Variabilità e Mutabilità, Bologna: Paolo Cuppini (in Italian).

Goldin C., Katz L. F., Kuziemko I. (2006) The Homecoming of American CollegeWomen: The Reversal of the College Gender Gap. Journal of Economic Perspectives, vol. 20, no 4, pp. 133-156.

Gottschalk P., Moffitt R. (2009) The Rising Instability of U.S. Earnings. Journal of Economic Perspectives, no 23, pp. 3-24.

Jenkins S. P. (2011) Changing Fortunes, Oxford: Oxford University Press.

Jenkins S. P., van Kerm P. (2009) The Measurement of Economic Inequality. The Oxford Handbook of Economic Inequality (eds. W. Salverda, B. Nolan., T. M. Smeeding), Oxford: Oxford University Press, pp. $40-67$.

Jorgenson D. (1998) Did We Lose the War on Poverty? Journal of Economic Perspectives, no 12, pp. 79-96.

Kanbur R., Wagstaff A. (2014) How Useful Is Inequality of Opportunity asa Policy Construct? ECINEQ Working Paper, no 338, pp. 1-18. 
Karoly L. A. (1994) The Trend in Inequality among Families, Individuals, and Workers in the United States: A Twenty-five Year Perspective. Uneven Tides (eds. S. Danziger, P. Gottschalk), New York: Russell Sage Foundation, pp. 19-97.

Kopczuk W., Saez E., Song J. (2010) Earnings Inequality andMobility in the United States: Evidence from Social Security Data since 1937. Quarterly Journal of Economics, no 125, pp. 91-128.

Krueger D., Perri F. (2006) Does Income Inequality Lead to Consumption Inequality? Review of Economic Studies, no 73, pp. 163-193.

Lucas R. E. (2003) The Industrial Revolution: Past and Future. The Region, 2003 Annual Report of the Federal Reserve Bank of Minneapolis, Minneapolis: Federal Reserve Bank, pp. 5-20.

Mankiw N. G. (2007) Principles of Microeconomics, 7th ed., New York: Worth.

Mankiw N. G. (2014) Essentials of Economics, 7th ed., New York: Worth.

McCarty N., Poole K. T., Rosenthal H. (2006) Polarized America: The Dance of Ideology and Unequal Riches, Cambridge, MA: MIT Press.

Meyer B. D., Sullivan J. X. (2012) Winning the War: Poverty from the Great Society to the Great Recession. Brookings Papers on Economic Activity(Fall), pp. 133-200. Available at: https://www.brookings.edu/ bpea-articles/winning-the-war-poverty-from-the-great-society-to-the-great-recession/ (accessed $21 \mathrm{March}$ 2017).

Miller H. P.(1966) Income Distribution in the United States, Washington, DC: Bureau of the Census.

Morelli S., Smeeding T. M., Thompson J. (2014) Post-1970 Trends in Within-Country Inequality and Poverty. Handbook of Income Distribution (eds. A. B. Atkinson, F. Bourguignon), vol. 2, Amsterdam: North Holland, pp. 593-696.

Obituary for James Tobin. (2002) Yale Bulletin and Calendar, vol. 30, no 22 (15 March).

OECD (2011) Divided We Stand: Why Inequality Keeps Rising, Paris: OECD.

Orshansky M. (1965) Counting the Poor: Another Look at the Poverty Profile. Social Security Bulletin, no 28 , pp. 3-29.

Pen J. (1971) Income Distribution, London: Allen Lane.

Pickett K., Wilkinson R. (2010) The Spirit Level, rev. ed., London: Penguin.

Piketty T. (2014) Capital in the Twenty-First Century, Cambridge, MA: Harvard University Press.

Piketty T., Saez E. (2003) Income Inequality in the United States, 1913-1998. Quarterly Journal ofEconomics, no 118 , pp. 1-39.

Plato (1960) The Laws. V. 744e, New York: Dutton. 
Ponthieux S., Meurs D. (2014) Gender Inequality. Handbook of Income Distribution (eds. A. B. Atkinson, F. Bourguignon), vol. 2A, Amsterdam: North Holland, pp. 981-1145.

Rawls J. (1971) A Theory of Justice, Cambridge, MA: Harvard University Press.

Roemer J. (1998) Equality of Opportunity, Cambridge, MA: Harvard University Press.

Rowntree B. S. (1922 [1901]) Poverty: A Study of Town Life, London: Longmans, Green and Co.

The Royal Commission on the Distribution of Income and Wealth (1979) Report No. 7, Fourth Report on the Standing Reference, Cmnd. 7595, London: HMSO.

Sabelhaus J., Johnson D., Ash S., Garner T., Greenlees J., Henderson S., Swanson D. (2012) Is the Consumer Expenditure Survey Representative by Income? Finance and Economics Discussion Series, Divisions of Research \&Statistics and Monetary Affairs, Washington, D.C.: Federal Reserve Board, Available at: https:// www.federalreserve.gov/pubs/feds/2012/201236/201236pap.pdf (accessed 15 March 2017).

Sandmo A. (2015) The Principal Problem in Political Economy: Income Distribution in the History of Economic Thought. Handbook of Income Distribution (eds. A. B. Atkinson, F. Bourguignon), vol. 2A, Amsterdam: Elsevier, pp. 3-65.

Sen A. (1973) On Economic Inequality, Oxford: Clarendon Press.

Sen A. (1999) Development as Freedom, Oxford: Oxford University Press.

Sen A. (2009) The Idea of Justice, London: Allen Lane.

Smith A. (1903 [1776]) An Inquiry into the Nature and Causes of the Wealth of Nations, London: Routledge.

Social Protection Committee (2014) Social Europe: Many Ways, One Objective, Luxembourg: Publications Office of the European Union.

Solow R. M. (1960) Income Inequality since the War. Postwar Economic Trends in the United States (ed. R. E. Freeman), New York: Harper and Brothers, pp. 91-138.

Solow R. M. (2003) Dumb and Dumber in Macroeconomics. Available at: https:/www0.gsb.columbia. edu/faculty/jstiglitz/festschrift/ Papers/Stig-Solow.pdf (accessed 15 March 2017).

Stiglitz J. E. (2012) The Price of Inequality, London: Allen Lane.

Tawney R. H. (1913) Poverty as an Industrial Problem. Memoranda on the Problems of Poverty, London: William Morris Press.

Tawney R. (1961 [1931]) Equality, London: Allen and Unwin.

Tobin J. (1970) On Limiting the Domain of Inequality. Journal of Law and Economics, no 13, pp. $263-277$.

Toynbee P., Walker D. (2009) Unjust Rewards, London: Granta. 
U.S. Bureau of the Census (2014) Income, Poverty, and Health Insurance Coverage in the United States: 2013. Current Population Report, Washington, D.C.: U.S. Bureau of the Census.

U.S. Bureau of the Census (2014) Income and Poverty in the United States: 2013. Annual Social and Economic Supplement to the Current Population Survey, Washington, D.C.: U.S. Bureau of the Census. Available at: http://www.census.gov/content/dam/Census/library/publications/2014/demo/p60-249.pdf (accessed 21 March 2017).

Weichselbaumer D., Winter-Ebmer R. (2005) A Meta-Analysis of the International Gender Wage Gap. Journal of Economic Surveys, no 19, pp. 479-511.

Wootton B. (1955) The Social Foundations of Wage Policy, London: Allen \& Unwin.

World Top Incomes Database (WTID). Available at: http://topincomes.g-mond.parisschoolofeconomics. eu/ (accessed 21 March 2017).

Received: March 14, 2017.

Citation: Atkinson A. B. (2017) Chto takoe “neravenstvo," i mozhem li my ego preodolet'? [Inequality: What can be Done? (an excerpt)], Journal of Economic Sociology = Ekonomicheskaya sotsiologiya, vol. 18, no 2, pp.41-79. Available at https://ecsoc.hse. ru/2017-18-2.html (in Russian). 


\section{А. А. Андреева, Ю. Д. Климешова, М. А. Кудрявцева, А. П. Лобанова \\ Рационализация жизни современного человека на примере анализа потребления воды жителями Москвы ${ }^{1}$}

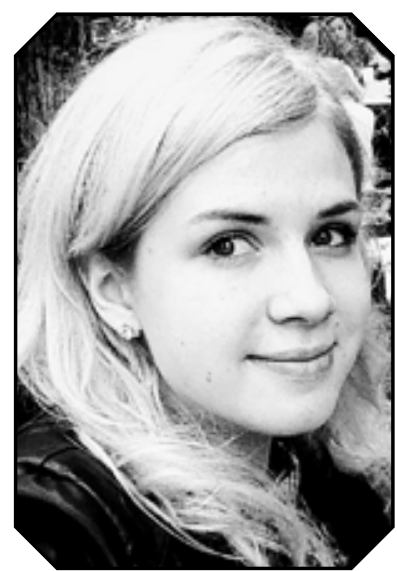

АНДРЕЕВА Анастасия Александровна студентка бакалаврской программы «Социология» факультета социальных наук НИУ ВШЭ. Адрес: Россия, 101000, г. Москва, ул. Мясницкая, д. 20.

Email: aaandreeva_2@ edu.hse.ru
Увеличение спроса на питьевую воду, а также товары и услуги, связанные с её потреблением, указывает на трансформацию практик потребления воды в современной России. Данное исследование примыкает к группе теорий, предполагающих, что сегодня даже физиологические прочессы попадают в зону дисциплинарного контроля, что в совокупности с хелсизмом ${ }^{2}$, медикализачией, развитием рынка питьевой водь вносит вклад в нарастаюшую рационализацию повседневности. Представляется необходимым оценить, как подобные тенденции проявляются в российском обществе, на примере практик потребления питьевой воды. В рамках исследования в городе Москве были проведены 26 глубинных интервью, анализ которых осуществлялся в соответствии с логикой обоснованной теории путём открытого и выборочного кодирования нарративов.

В результате исследования демонстрируется тенденция к управлению жаждой: механизмы контроля за потреблением воды, а также намеренное увеличение потребляемого объёма через стремление к заданной «норме». Калькуляиия в практиках информантов проявляется через рефлексию и неосознанный учёт не только объёма воды, но и иены, времени и комфорта потребления. При этом в отдельных сочиальных контекстах (занятия спортом, похудение, беременность) опривычивание социальносконструированных норм потребления воды достигает стадии перехода во внутреннюю потребность. Критерии оченивания качества и пользы потребляемой воды черпаются информантами в повседневном знании, рекламе бутилированной воды, а также в консультащиях экспертов самого разного толка. Неопределённость в отношении «чистоты» и «безопасности» воды заполняется подчас иррациональными верованиями.

Ключевые слова: рационализация; дисциплинарная власть; повседневность; калькуляция; хабитуализация; медикализация; хелсизм; институциональное регулирование; контроль; качество воды.

Авторы работы признательны анонимным рецензентам за ценные замечания и рекомендации, позволившие повысить качество данной статьи, а также научному руководителю Елене Сергеевне Бердышевой за идейное вдохновение, помощь и комментарии на всех этапах проведения исследования.

2 Термин «хелсизм» (healthism, от англ. health - здоровье) описывает идеологическое течение, в рамках которого ведение здорового образа жизни индивидом рассматривается в качестве его морального долга в той мере, в которой здоровье любого человека вносит вклад во всеобщее благосостояние. Впервые предложен Робертом Кроуфордом в статье «Хелсизм и медикализация в повседневной жизни» (см.: [Crawford 1980]). 


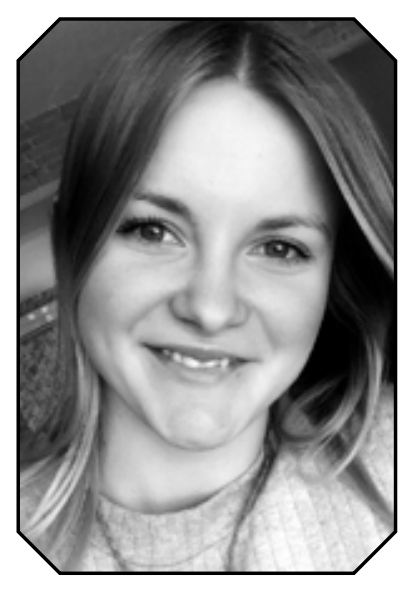

КЛИМЕШОВА ЮЛИЯ Дмитриевна -

студентка бакалаврской программы «Социология» факультета социальных наук НИУ ВШЭ. Адрес: Россия, 101000, г. Москва, ул. Мясницкая, д. 20.

Email: klimeshova.yuliya@ gmail.com

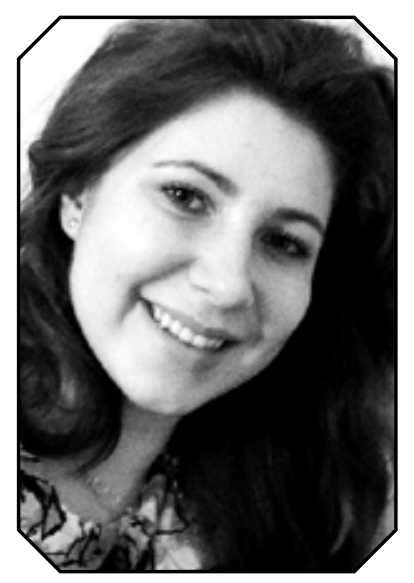

КУДРЯВЦЕВА Мария Александровна студентка бакалаврской программы «Социология» факультета социальных наук НИУ ВШЭ. Адрес:

Россия, 101000, г. Москва, ул. Мясницкая, д. 20.

\section{Email:}

makudryavtseva_1@edu. hse.ru

\section{Введение}

В начале XX века классики социологии улавливали первые веяния рационализации жизни и указывали на то, что подобные тенденции только набирают силу (см.: [Вебер 2016 (впервые: 1921); Элиас 2001 (впервые: 1939)]. Спустя век гипотеза о том, что устройство повседневной жизни всё больше подчиняется разуму, не теряет своей актуальности. Более того, установки на оптимизацию и контроль интернализируются современным человеком и подчиняют себе не только внешние деяния, но и физиологические процессы [Бандурин, Бандурин 2015]. В нашей работе на российском эмпирическом материале анализируется, какие социально-экономические механизмы используются для того, чтобы такая естественная потребность, как жажда, попала в зону дисциплинарного контроля [Фуко 1999].

Вопрос потребления воды имеет внедискурсивную природу и кажется странным в силу сложившейся культурной нормативности [Бергер, Лукман 1995]. В связи с установками о естественности процесса потребления воды не рефлексируются ни сам процесс, ни мотивы потребления. Хотя именно в рутинных ежедневных действиях раскрывается социальный порядок [Штомпка 2009: 8].

Мировоепотреблениеводы неуклонно растёт [Facts and Trends... 2016], и прогнозируется, что эта тенденция продолжится [Global Water Demand... 2015]. Активно развивается и рынок бутилированной воды: мировое потребление к 2015 г. за пять лет увеличилось со 170 до 233 млрд литров и впервые превысило спрос на основные субституты - газированные напитки (227 млрд литров) [Global Packaged Water Consumption... 2015].

Российский рынок бутилированной воды не является исключением и характеризуется ростом спроса с 2000-х гг.; причём постоянно увеличивается доля питьевой природной воды (негазированной и неминеральной) [Рынок бутилированной воды... 2016]. Кроме того, за последние три года в России было разработано большое количество специализированных приложений и программ, позволяющих контролировать уровень потребления воды (например, приложение iDrink [iDrink 2014]), стали пользоваться популярностью статьи о здоровом образе жизни и потреблении воды [Как заставить себя выпивать норму воды в день... 2015], разнообразные семинары и тренинги, посвящённые правильному питанию и употреблению воды [Водный баланс организма... 2016], появились специальные измерители качества и очистители воды (например, Ph-метр [Рh-метр 2016]), кружки и бутылочки, делающие приём воды приятнее, эстетичнее и моднее [My Bottle 2016].

Как увеличение спроса на питьевую воду, так и повсеместное распространение товаров и услуг, связанных с потреблением воды, позволяют предположить, что в современном российском обществе происходят трансформации практик потребления воды. При этом вектором изменений, похоже, является рационализация данных практик. С учётом того, что потребительские порывы зачастую производны от смены культурного фона, деконструкция практик потребления воды современным россиянином позволяет увидеть, 


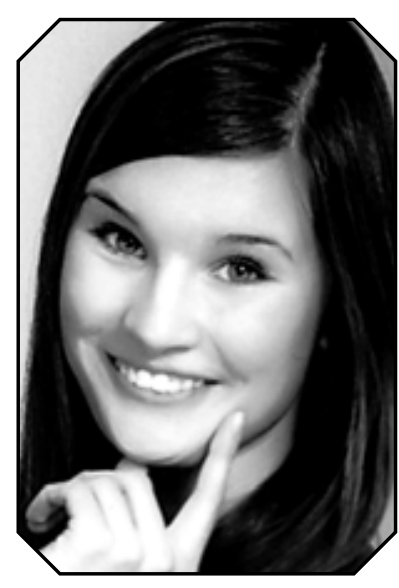

ЛОБАНОВА Анастасия

Петровна - студентка бакалаврской программы «Социология»

фракультета социальных наук НИУ ВШЭ, стажёр-исследователь Лаборатории исследований науки и технологий НИУ ВШЭ. Адрес: Россия, 101000, г. Москва, ул. Мясницкая, д. 20.

Email: aplobanova@edu. hse.ru как в нашей стране формируются новые культурные установки, связанные с ответственностью за тело, здоровье и благополучие индивидов.

Цель исследования заключается в том, чтобы прояснить социальные основания практик потребления питьевой воды в современном российском обществе и оценить структуру этих практик в ракурсе приближённости к рациональному поведению. На основе информации, полученной в процессе исследования, мы намерены реконструировать культурные, экономические и институциональные условия трансформации, потенциально способные влиять на формирование практик индивидов и их отношение к питьевой воде. Также видится целесообразным выявить смысловые категории, стоящие за потреблением питьевой воды россиянами, описать элементы калькулятивного поведения, проявляющиеся в практиках потребления питьевой воды, продемонстрировать, как действует механизм контроля, на примере данного аспекта повседневной жизни индивидов.

Структура работы будет следующей: в начале представлены основные подходы к концептуальному пониманию процесса рационализации, которые послужили базой для построения теоретической модели исследования. Затем приводится обоснование основных методологических решений и структуры выборки. Описание эмпирических результатов начинается с типологии практик потребления воды, а также проблематизации вариаций этих практик, выявляемых при сравнении нарративов респондентов различных пола, возраста и места проживания. Далее показано, какие институты используются респондентами в качестве источников информации о том, как правильно пить воду, а также как неопределённость по поводу её качества заполняется доверием к институтам, приписыванием воде символической значимости, использованием ритуальных практик. Речь также пойдёт о том, как контроль реализуется в осознанном и латентном учёте цены, времени, объёма потребляемой воды и степени комфорта в процессе потребления. Были зафиксированы усилия, которые предпринимают информанты, чтобы изменить свои привычки, на основе чего представлена типология стратегий «опривычивания». Также обсуждается связь между степенью опривыченности нового питьевого режима и необходимостью в явном контроле потребления питьевой воды. В заключение эмпирические результаты осмыслены в свете социологических теорий.

\section{Процесс рационализации через призму социологических теорий}

Как известно из работ М. Вебера, процесс рационализации неразрывно связан с процессом «расколдовывания мира», то есть отрицания магических, мистических и иных потусторонних сил природы, и с повышением роли научного знания в жизни общества. Рационализация для Вебера - это переход от хаотичных действий, событий или явлений в систематическую и упорядоченную сферу жизни. Классик неоднократно подчёркивал, что процесс рационализации пронизывает все аспекты жизни людей, однако дискуссионным ядром для него выступал макроуровень: государство, производство, религия [Вебер 2016]. Вебер считал, что рационализация является 
показателем исторического развития и роста, подразумевает контроль государства над всеми сферами жизни общества, то есть контроль над действиями индивидов. С ним соглашался Н. Элиас, также изучавший тяготение общества к более полному контролю над повседневной жизнью как механизм принуждения, связанный с интересами в обеспечении производственной силы тела, полезной для государства [Элиас 2001]. Терминологически данная идея оформляется в работах М. Фуко, говорящего о дисциплинарной власти, которая подразумевает «полный охват < ..> тела, жестов, времени, поведения индивидов» [Фуко 2007: 64]. При реализации дисциплинарной власти появляются практики, которые используются индивидами для того, чтобы самостоятельно или при помощи какого-либо внешнего фактора воздействовать на собственные тела (такие практики М. Фуко называл техниками себя). Опираясь на принципы психоанализа, он показал, что цель подобных трансформаций - приближение к совершенству и чистоте [Фуко 2008]. При этом знание о себе вписано в определённые формы господства, то есть навязано извне. «Политическая экономия тела» направлена на подчинение людей через некие нормы телесности, принятые в обществе, при помощи которых государство диктует, что и как делать индивиду, продвигая, таким образом, свои цели. Забота о здоровье населения является важной задачей государства, а создание культуры здорового образа жизни у населения даёт возможность снизить заболеваемость и как результат затраты на медицинскую сферу [Crawford 1980]. Государство определяет, каким должно быть тело, а задачей индивидов является подстраивание под образец для достижения максимальной эффективности возможностей своего тела, которое выступает не как естественная природная данность, но как объект целенаправленных усилий.

Новый аспект нормативной телесности - её рационализация, появившаяся вследствие возрастания роли науки и её обоснованности, а также медикализация как частный случай распространения рационализации на жизнь общества через институты. Теперь здоровое тело - идеал, к которому необходимо стремиться. Медицина начала контролировать общество, определяя границу между здоровым и нездоровым телом, помогая восстановить здоровое тело, то есть определяя нормативную телесность уже индустриального общества. В рамках идеологии хелсизма ведению здорового образа жизни придаётся моральная окраска, а нарушения стигматизируются.

Индивид учится контролю над своим телом, стремится принимать активное участие в его формировании и избегать подчинения своим потребностям во благо самого себя. Забота о себе и контроль над собой становятся стилем жизни, но человек не превращается в эгоиста или асоциальную личность; наоборот, благодаря контролированию появляются новые оформленные институты. «Призыв “заботиться о себе” стал императивом < ..>, он стал образом действия, манерой поведения, пропитал различные стили жизни, оформился в многочисленные процедуры, практики, предписания, которые осмысляли, развивали, совершенствовали, преподавали» [Фуко 1998: 53]. Причём важно, что ответственность за здоровье теперь лежит на индивиде, который должен не только действовать определённым образом, но и контролировать себя самостоятельно [Паутов, Паутова 2014]. Для россиян, имеющих более чем полувековой опыт патерналистской системы здравоохранения, подобные установки на внутренний локус контроля являются новыми.

По мнению отдельных исследователей, институты были сформированы экспертами (наследниками философов), которые противопоставляются невеждам [Элиас 2001; Дуглас 2007]. По сути, невежды - это люди, живущие в той повседневности и рутинности, которая им дана. Эксперты же живут рационализированной, точной жизнью. Места, в которых осуществляли свою деятельность эксперты, и были зарождёнными институтами. Теперь эти эксперты находятся повсюду, оказывая влияние на всё общество, а институты, которые ранее принадлежали только им, теперь действуют для всех индивидов [Вальденфельс 1991]. 
Контролирование собственного тела на практике разворачивается в различные практики калькуляции, неизменно сопутствующие рационализации общества [Вебер 2007]. Всё начинает просчитываться, действия людей оцениваются с точки зрения наилучшего пути к достижению цели и при этом предстают в числовом выражении. Важно, что подсчёт осуществляется без натуги - общество устроено таким образом, что любое действие так или иначе стремится быть «опривыченным» [Ритцер 2011]. Происходит хабитуализация: выполняя одно и то же действие, мы осознаём его как некий образец, после чего нам сложно представить, что его можно осуществить другим образом [Бергер, Лукман 1995]. Образцы включаются в практики индивида как «само собой разумеющееся»; для индивида становится очевидным, что нужно поступить именно определённым образом, возможности выбора существенно сокращаются. Так, в результате процесса хабитуализации вырабатывается некий алгоритм действий для определённой ситуации, по своей сути ничем не отличающийся от того алгоритма, который создаётся для робота. Разница лишь в том, что социальная жизнь очень разнообразна, а образцы поведения сложнее компьютерных алгоритмов, так как постоянно корректируются в зависимости от ситуации. Итак, мы видим, что практики стремятся к механизации. Последующее повторение может быть осуществлено с экономией усилий. Действительно, хабитуализация в значительной степени упрощает нашу жизнь. При этом привычные практики могут либо соотноситься с актуальными целями индивида, либо противоречить им. Мы называем некоторые действия вредными привычками, то есть осознаём различие между нашими желаниями и действиями. Также индивиды, оценивая силу привычки, нередко пытаются искусственно хабитуализировать то, что соответствует их целям [Verplanken, Faes 1999], «сами делают себя», занимаясь созданием «хорошей персоны» [Морено 2001] 3 .

В повседневной жизни люди чаще принимают решения постепенно, чтобы уменьшить или вообще избежать умственных математических вычислений [Northcote, McIntosh 1999]. Ускользает от рефлексии действующего и природа его предпочтений, в том числе и потребительских. Ожидания в отношении качеств товаров на деле отсылают к общекультурным нормам [Слейтер 2008]. Но рынок улавливает ожидания раньше потребителя и обучает его способам оценивания, по сути, социально сконструированного блага [Каллон, Меадель, Рабехарисоа 2008]. В случае с питьевой водой данный вопрос приобретает дополнительные этические измерения. Пригодная для питья вода является благом, необходимым для выживания человека. Во многих странах мира право человека на доступ к питьевой воде относится к разряду базовых гражданских прав, которые должны быть обеспечены государством. При этом в развитых странах сегодня это право обсуждается в связи с бурным развитием рынков бутилированной воды, где возникают все сопутствующие коммодификации жизненно важного блага в консьюмеристском обществе дилеммы [Бердышева 2010]. В это же время в бедных странах вопрос об обеспеченности питьевой водой по-прежнему возникает в связи с неспособностью некоторых государств организовать производство данного общественного блага [Clarke 2004].

Современное общество - это общество риска [Бек 2000]. Потребление же питьевой воды исторически погружено в проблематику чистоты и опасности [Strang 2004; Trentmann, Taylor 2006; Дуглас 2007]. И потому маркетинговые усилия компаний-производителей, направленные на создание мнения о том, что бутилированная вода более пригодна для питья (например, по сравнению с водопроводной), находят отклик у потребителей. При этом социальным исследователям понятно, что доминирующие представления о том, какой должна быть вода, оказываются продуктом усилий заинтересованных акторов. «Вода — это то, что мы о ней думаем» [Linton 2010]. Однако в результате процесса коммерционализации у воды как у общественного блага появляется денежная цена, из чего неизменно вытекает вопрос о том, каким социальным группам «качественная» вода теперь не будет доступна [Wilk 2006].

Таким образом, данное исследование базируется на группе теорий, предполагающих, что в современном обществе даже физиологические процессы подвергаются в первую очередь социальной регуляции

3 Термин «хорошая персона» используется в социальной психологии. 
и регламентации, что в совокупности с множеством других процессов вносит вклад в нарастающую рационализацию современного общества, в том числе и в России. Ожидается, что анализ практик потребления питьевой воды позволит увидеть механику этой регламентации, выявить, как диктуемые культурой и социальной политикой нормы интериоризируются индивидами, структурируют их жизнь и - через самоограничение и контроль - превращаются в каноны здравого смысла, на самом деле являющиеся историко-социальными конструктами.

\section{Методология и выборка исследования}

Исследование выполнено в качественной стратегии, что предполагает установку авторов не на проверку гипотез, как в количественном исследовании, а на вычленение их из эмпирического материала. Основной задачей исследования являлось построение плотного описания изучаемого феномена, в данном случае - практик потребления воды москвичами. Требовалось репрезентировать и объяснить их путём получения максимально полной палитры мнений. Исследование носило разведывательный характер, не предполагающий оценки средних тенденций, характеризующих социальную группу или население страны в целом.

Объектом нашего исследования является всё население России. Однако, исходя из предположения, что рационализация потребления воды является относительно новым феноменом, было принято решение сфокусироваться на жителях Москвы. Как свидетельствуют исследования, доля так называемых потребителей-новаторов среди жителей столицы максимально высока. Москва зачастую оказывается площадкой, где вызревают и оформляются новые практики, которые затем с высокой вероятностью становятся эталоном для жителей регионов России [Бабурин, Земцов 2013]. В результате эмпирическим объектом нашего исследования были выбраны жители Москвы.

Основным методом сбора данных было глубинное интервью. Структура гайда продиктована теоретическими основаниями работы и включала следующие блоки: общая информация; институциональное оформление потребления воды; социальное конструирование представлений о пользе и качестве воды; калькуляция; хабитуализация.

Выборка исследования формировалась в логике теоретической выборки, практикуемой в рамках обоснованной теории [Корбин, Страусс 2001]. Первостепенным требованием было обеспечение гетерогенности выборки, так как сравнение и контрастирование нарративов респондентов, обладающих различными социально-демографическими характеристиками, позволяли рассчитывать на получение насыщенного описания изучаемых практик.

Из исследований по социологии и антропологии потребления известно, что одним из главных источников вариации установок по отношению к телу и здоровью в современном обществе является гендерная принадлежность [Гапова 2005]. Кроме того, практики самозаботы меняются на протяжении жизненного цикла и в межпоколенческом разрезе, поэтому их вариативность в контексте потребления воды может быть зафиксирована при сравнении нарративов респондентов разного возраста [Ковалёва 2008; Рощина 2016]. Ещё один параметр, необходимость фиксации которого была очевидна на этапе входа в поле - это род занятости. Теоретическая рамка исследования указывает на то, что потребление воды вписано в контексты хелсизма и медикализации. Следовательно, представители экспертных сообществ, работающих с этими контекстами, то есть врачи, спортсмены, фитнес-тренеры, должны были быть включены в выборку.

Для участия в интервью были приглашены люди, как лично знакомые интервьюерам, так и находящиеся вне круга общения исследователей. Использование пула наших знакомых позволило до интервью 
прорефлексировать практики окружающих и выбрать лиц, чьи практики отличаются от тех, что были уже нами зафиксированы. В этом смысле знакомство с информантом, хотя и поднимает вопрос об ограничениях доступной выборки, оказывается полезным. В некотором роде «острота проблемы» снижается, во-первых, за счёт того, что интервью проводили все четыре участника нашей исследовательской команды. Соответственно, несмотря на то что наши круги общения пересекаются, их совокупность значительно шире каждого в отдельности. Во-вторых, мы провели четыре интервью с людьми, с которыми не были знакомы прежде; они сами изъявили желание выразить своё мнение, откликнувшись на объявление в социальных сетях. И, в-третьих, тема потребления воды не является сензитивной, поэтому нет оснований говорить о значимом смещении в ответах информантов. Поскольку вопрос репрезентативности выборки и генерализации выводов в нашем исследовании не стоит, мы считаем такое ограничение оправданным.

Все полученные интервью были последовательно транскрибированы. В соответствии со стратегией открытого кодирования цитаты, касающиеся изучаемого аспекта, распределялись по категориям, им присваивались определённые коды, которые далее объединялись по подтемам. Нас интересовали повторяющиеся сюжеты, а также нетипичные практики потребления воды у информантов, действующих в различных сегментах социального пространства. Следуя стратегии выборочного кодирования, мы повторно проанализировали тексты, ориентируясь на концептуальную модель исследования [Корбин, Страусс 2001]. Для анализа использовалась программа «Microsoft Office Excel 2007».

Всего в исследовании приняли участие семь мужчин и 19 женщин в возрасте 17-72 лет (39\% из них старше 25 лет; 61\% соответственно младше), проживающие в Москве давно (22\%) или переехавшие недавно (35\%), а также в ближайшем Подмосковье (35\%) и других городах России (8\%). Отдельно стоит выделить интервью с врачом, спортивным тренером, преподавателем йоги и профессиональным спортсменом, которые составили экспертную группу в рамках данного исследования. Более подробно характеристики каждого информанта представлены в таблице П.1 (см. приложение).

Среднее время интервью составило около 40 минут, общий объём транскриптов - более 13 авторских листов.

\section{Новый взгляд на потребление воды: результаты исследования}

\section{«Пью только, чтобы утолить жажду?»}

Первостепенной задачей исследования было выявление смысловых контекстов потребления воды. Анализ эмпирических данных позволил увидеть, что в современном обществе мотивация потребления воды не ограничивается простым утолением жажды, с чем связана востребованность инструментов контроля и управления им. Весь спектр практик условно можно разделить на четыре группы на основе того, как информанты осмысливают процесс потребления воды:

- утоляющие жажду. Представители данной группы пьют воду «по потребности», следуя своим физиологическим реакциям, при этом они не уделяют специального внимания количеству выпитой воды;

- ЗОЖники и ППшники. Следует отметить: хотя ведение здорового образа жизни (ЗОЖ) сегодня и задаёт особый вектор развития идентичности человека, на практике представление о том, что именно входит в здоровый образ, весьма вариативно. Мнения сходятся лишь по поводу исключения алкоголя и других вредных веществ из своего рациона, действия во благо своему организму и соблюдения режима сна и питания. Примечательно, что в то же время информан- 
ты определяют некую критичную черту, переход которой превращает ведение здорового образа жизни в «паранойю». Тем не менее для «ППшников» (сторонников правильного питания) потребление воды - один из основных аспектов соблюдения здорового образа жизни В их поведении явно прослеживается статусный элемент. Вербализуемая ими установка — пить рекомендуемое экспертами количество воды «на автомате», при этом нормы реального потребления воды могут сильно отличаться от физиологической потребности. Нередко представители данной группы пьют воду, рассуждая о «её роли для ускорения метаболизма», легко оперируя экспертной терминологией. Также ведётся подсчёт количества выпиваемой воды, причём в фокусе находится поиск нормы (нельзя выпить не только меньше, но и больше). «Му bottle» («Моя бутылка») в руках становится символом того, что ты не просто пьёшь воду, но и владеешь сакральным знанием о том, что делать, чтобы выглядеть красивее и худее других, а значит, «круче». Потребление воды становится демонстративным. Люди пьют, чтобы выделяться, чтобы было «видно, что ты явно на спорте» и настроен выполнять норму «худого тела», воспеваемую современной культурой;

- «не чувствовать себя белой вороной». Данная группа потребителей, скорее, улавливает моду на здоровый образ жизни. Они пьют воду под влиянием окружающих, попадая в референтные группы, в которых это актуально;

Я как-то стояла и думала, может, купить и попробовать, что там «белье люди» пьют, но потом поняла, что не стоит (Мария, 22 года).

- «хочешь - пьёшь, не хочешь - не пьёшь». Таков принцип четвёртой группы потребителей. В отличие от первой группы - «утоляющих жажду», - представители этой группы демонстрируют весьма осознанное отношение к потреблению воды и вместе с тем недоверие к навязываемым извне нормам потребления, пропагандируя необходимость выработки индивидуальных норм, соответствующих потребностям конкретного организма.

Независимо от того, к какой группе принадлежит каждый конкретный информант, в ходе интервью становилось ясно, что не только исследователи, но и обыватели видят: вопрос потребления воды сегодня выходит из тени.

Были времена, когда пили воду, если хочется пить, а не потому, что тебе надо выпить 1,5 литра воды (Мария, 22 года).

Молодые респонденты видят собственное поведение как отличное от поведения представителей других поколений:

Воду пью только я, для родителей это нетипично (Мария, 22 года).

Респонденты размышляют о том, что в военное и послевоенное время, когда существовал голод, много смертей, разруха и тому подобное, людям было недосуг задумываться о том, как они пьют воду. Профицит и достаток, а также освоение представлений о требованиях к чистоте воды, оформленных в государственной политике, замечаемых при сравнении отношения к воде в разных странах (например, в ходе туристических поездок), позволяют задуматься о роли воды и заставляют тратить время на контроль её качества и объёма потребления. 


\section{Вариативность практик потребления воды в зависимости от пола, возраста и места проживания}

Проживание в Москве является параметром, способным запустить более осознанное отношение к потреблению питьевой воды. Намеренное включение в выборку респондентов, которые приехали в Москву недавно, позволяет увидеть, что непривычные нормы потребления воды оказываются для них одним из «культурных шоков»:

Раньше, до переезда, я пила воду из-под крана и относилась к этому нормально. При этом я знала, что качество воды удовлетворительное как минимум, а здесь я не могу быть уверена, поэтому всё же остерегаюсь (Надежда, 20 лет).

Также нам удалось зафиксировать, что существует некие гендерные различия в смыслах относительно потребления воды и пользы этого действия. Различия могут прослеживаться уже на нормативном уровне; информанты воспроизводили правила, в которых мужчинам предписывалось большее употребление воды, чем женщинам:

Женщинам нужно выпивать от двух до 2,7 литра водьв в день, а мужчинам 一 от 2,7 до 3,5 литра (Валерия, 21 год).

В рамках данного исследования невозможно выяснить, больше или меньше мужчины по сравнению с женщинами пьют воды, но можно выделить различия в установках информантов обоих полов. Прежде всего, следует отметить, что мы встретились со скептическим и даже негативным отношением к новым практикам потребления воды со стороны мужского пола:

Я замечаю, что он (Молодой человек. - Aвторы.) не может кушать, не запивая водой. Это для него абсолютно неестественно. Ну, он не будет никогда с утра пить воду. Но он может прийти вечером и перед сном выпить, если у него сильная жажда, четыре стакана воды (Дарья, 22 года);

Она (Жена. - Авторы.), как все типичные женщины, повёрнута на похудении и на правильном питании, поэтому она хлещет воду как ненормальная (Илья, 28 лет).

Таким образом, наши респонденты подчёркивают, что, в отличие от женщин, для мужчин потребление воды - естественный процесс, заключающийся в её употреблении по желанию. Похудение, правильное питание, улучшение внешнего вида (состояние кожи, её цвета, поддержание чистоты кожи) как «триггеры» изменения привычек, отмеченных женщинами, представляются чуждыми для мужчин. Соответственно практики мужчин отличались от таковых у женщин меньшей заинтересованностью в изменении своих привычек по потреблению воды.

Можно было бы предположить, что в силу «общей культуры питания» в семье практики потребления воды будут схожими. Тем не менее существуют гендерные расхождения внутри семьи. Но женщины стараются транслировать своё видение партнёру, проявляя настойчивость и гибкость одновременно:

Я сделаю нам одну и ту же пищу («здоровую»), просто ему, может быть, положу большую пориию, дам ему тот же самый майонез, кетчуп или что-нибудь такое. Может быть, я ему налью сок, который сама точно пить не буду (Дарья, 22 года); 
Он (Муж. - Авторы.) пьёт обычно чай или ещее что-нибудь, а я заставляю его пить воду (Алла, 43 года).

Иными словами, женщины готовы идти на уступки мужчинам, стараясь сильно не разграничивать питание, но в то же время постепенно прививать «культуру питания». Этот процесс напоминает воспитание детей. Сюжеты о необходимости формирования «правильной» культуры потребления воды в детстве (в том числе у сыновей) следует выделить отдельно:

Заставляю пить его с утра. Приучаю с детства его. Его-то я, наверное, приучу в отличие от старшего (Алла, 43 года).

Кроме того, намечается разделение мужских и женских функций. Мужчины вовлекаются в хозяйственный процесс организации потребления воды, оказываются ответственными за заказ воды или обслуживание фильтров, а женщины, в свою очередь, акцентируют улучшение внешнего вида и поддержание веса, а также трансляцию своих «правильных» практик другим членам семьи:

Женщина больше на поддержание внешнего вида настроена: чистота кожи, вода же экологически чистая <...>. Поддержание веса — это больше по женской части. А мужчинь как общая идея здоровья, прежде всего реализаџия технических моментов, решение проблем семьи, обеспечение её более качественной как водой, так и пищей для всех. Разобраться, как это работает, решить, какой фильтр установить. Больше мужская обязанность (Сергей, 50 лет).

Подобные рассуждения дают нам основание полагать, что женщины являются удобной «мишенью» для транслирования новых практик, поскольку они, как правило, более внимательны к своему здоровью и внешности и потому более склонны к экспериментам в области здорового образа жизни. Однако затем мужчины оказываются всё более и более вовлечены в процесс «правильного» потребления воды благодаря тому, что женщины не только изменили свои практики, но и пытаются «привить эту полезную привычку» своим близким. Данные выводы соотносятся с результатами анализа рекламных роликов и слоганов известных марок бутилированной воды. Обратим внимание на основные категории, в которых маркетологи конструируют ценность продукта: «спорт», «семья», «здоровье», «красота» и «экология». При этом мы заметили, что модели женского пола появляются в рекламных роликах чаще, нежели мужского.

Отличительные особенности в потреблении воды также зависят от возраста. Несмотря на то что некоторые люди в возрасте сейчас стали задумываться о потреблении воды, практика увеличения её количества и следование норме всё же среди них не так распространена, как среди представителей молодого и среднего возраста, легче и быстрее усваивающих новые практики. Новые практики усваиваются быстрее представителями молодого и среднего возраста. Многие связывают это с тем, что с возрастом приверженность моде ослабевает, даже если под модой фигурируют вполне разумные основания.

Я могу сказать, что процент окружающих меня людей не стремится к этой моде. Мне кажется, это в силу возраста (Софья, 64 года).

Информанты также отмечали сильные различия в потреблении питьевой воды у двух соседних поколений или через поколение:

Сейчас говорят (бабушка и дедушка), что зачем вам в организм, который и так переваривает этот бутерброд, воду, которая создаст лишний объём, организму будет тяжелее всё это перерабатывать (Дарья, 22 года). 
Информанты молодого и среднего возраста, вспоминая о том, как пили воду их родители и бабушки с дедушками, воспринимают их практики потребления как отличные от современной «культуры питья воды». Тому, как это необходимо делать «правильно» сегодня, противопоставляется тот факт, что о потреблении не задумывались.

Родители на самом деле не приучень пить воду. <... Культура не сформирована у них самих (Ольга, 41 год).

Мне кажется, что нет, бабушки и дедушки не следили за потреблением воды в молодости, потому что тогда ещё не было такой пропаганды воды <... >, их это не озадачивало, и никак не волновал этот вопрос (Ксения, 20 лет).

Дети, в противоположность своим родителям и их родителям, пытаются привить практики правильного потребления воды своим детям так же, как это пытаются сделать женщины в отношении мужчин.

Представители различных поколений неодинаково оценивают цели потребления питьевой воды. Например, в нарративах представителей старших возрастов преобладает контекст «по медицинским показаниям», в интервью молодых — для похудения, поддержания веса, создания спортивной формы. Информанты старшего поколения ссылались на то, что начали следить за потреблением воды только с возрастом, в «молодости не до этого было». Однако их дети и внуки уже в своём возрасте задумываются о потреблении воды, причиной чему может послужить плотная институциональная пропаганда здорового образа жизни.

После 40 лет начала думать о воде, о своём питании (Полина, 66 лет);

Интервьюер: Вообще люди в Вашем окружении и Вашего возраста задумьваются, как пить воду?

Респондент: Конечно, задумывватся. Об этом говорят, следят за этим. < ..> чем больше пьёшь, тем лучше для организма (Светлана, 65 лет).

Всё же дискурсивное понимание того, что потребление воды должно зависеть от индивидуальных параметров, в том числе и от возраста, довольно распространено. Отмечается, что не только контролировать потребление воды, придерживаться нормы, намеренно снижать или увеличивать объём воды, но и задумываться об этом необходимо после достижения определённого возраста, когда это имеет смысл с точки зрения поддержания здоровья:

Доживём все до 40, а дальше посмотрим (Максим, 23 года);

Положено в моём возрасте (Виталий, 72 года).

\section{Чистота и опасность: управление качеством питьевой воды}

\section{Институциональное регулирование потребления питьевой воды}

Доминирующее сегодня представление о роли питьевой воды отсылает к тому, что вода для человеческого организма «важнее, чем еда». Как неоднократно упоминали респонденты, «человек без едbl может прожить неделю, а без воды три дня». Наличие химических примесей, тяжёлых металлов, бактерий в потребляемой воде вызывает у респондентов страх, который сродни экзистенциальному. Озабоченные качеством питьевой воды, респонденты в своих нарративах обращаются к вопросу о том, каким образом сегодня в России контролируется пищевая безопасность и чем она гарантируется. 
Выясняется, что результаты лабораторных исследований качества воды сегодня являются частью публичного дискурса. Информанты при аргументации своей позиции ссылаются на те или иные научные публикации, делая это по большей части обезличенно: «В исследованиях говорится...», «Считается, что...», «Исследователи доказали...» и т. п. Иными словами, анализ данных позволяет увидеть, что отношение людей к воде меняется в том числе и из-за популяризации этой темы в научных исследованиях. В ряду специалистов, занимающихся изучением воды, назывались биологи, физики, диетологи и др. В действительности, информанты не могли точно сформулировать причину полезности воды и назвать исследовательские группы или организации, которые этим занимаются. Общим местом среди причин, называемых в качестве необходимости пить больше воды, было то, что человеческий организм состоит из воды, но далее были варианты ответов: на 90\%, на 80\%, на 70\%, на 60\% и «на сколькото много процентов».

Государственные источники, ожидаемо, вызывают у респондентов больше доверия, чем результаты коммерческих исследований:

Роспотребнадзор, насколько я помню, делал статистику по воде, по брендам. Какую стоит и какую не стоит пить. Вообще, считаю, что Роспотребнадзор независим от коммериии и должен работать на благо людей (Виктор, 19 лет).

Однако контрольные меры, принимаемые государством, не перекрывают все вопросы, возникающие у респондентов, беспокоящихся о том, чтобы пить «благотворно влияющую» воду. Возникает частный спрос на соответствующие коммерческие услуги медицинских лабораторий, способных заверить или разуверить не только в качестве брендированной бутилированной воды, но любой воды (из крана, из ручья), поданной на анализ:

Есть куча независимых лабораторий, отдай ты туда полторашку, тебе проверят, что с ней не так. И опять же, если ты покупаешь бутилированную воду, ты чувствуешь, что у каждой бутылки вкус разный, то есть некоторые реально какие-то непонятные, вкус какой-то химозный (Максим, 23 года).

Информационные пробелы, если судить по полученным нарративам, могут заполняться советами тренеров и медиков. Эти последние обладают особым профессиональным знанием, они способны подойти к вопросу потребления воды с позиций выверенного знания о «химии и биологии человеческого организма»:

Мой тренер говорит, что если стакан тёплой воды выпить, то обмен вещцеств улучшится и ты похудеешь (Ксения, 20 лет).

Медицинские источники пользуются даже большим авторитетом. Неслучайно сегодня питьевая вода широко представлена на полках аптек. Медицина связывает качество воды с состоянием здоровья. В этой интерпретации «хорошая» вода сама по себе оказывается спасением и лекарством:

$<\ldots>$ Я пью воду только для почек. < .. > Специальная вода для почек, да, минеральная < .. > из Сербии заказываю (Андрей, 23 года).

Респонденты, которых не удовлетворяет информация о воде, исходящая от институциональных акторов, видят необходимость в прохождении профессионального обучения - они слушают лекции о правильном питании или питье, посещают семинары в школах правильного питания (например, Школа идеального тела «Секта»). Там слушатели узнают, как правильно выбирать воду, на что ориентиро- 
ваться, какая вода полезнее, а какая не даст результата в достижении желаемого эффекта. Информанты говорят о положительных результатах после прохождения обучения и уверены, что такой подход к пониманию своего тела правилен:

Прошло уже больше года после окончания, я понимаю, что до сих пор живу по правилам «Сектьл». Я чувствую, что организм в какой-то момент «спасибо» говорит (Яна, 22 года).

Коммерциализация питьевой воды, оформление соответствующих рынков, по-видимому, также влияет на практики людей.

Многие производители воды предпринимают маркетинговые ходы, чтобы покупали (Мария, 22 года).

Информанты замечают, что современный рынок воды отличается индивидуальным подходом к определённым группам людей: спортивная вода для спортсменов, детская вода для детей и т. д.

Анализ интервью позволяет зафиксировать, что важнейшую роль в практиках потребления воды играет сам факт покупки воды. Если информант платит за воду и знает, что это занимает определённую долю расходов, то, возможно, появляется необходимость допить или жёстче контролировать, сколько нужно выпить. Если же вода бесплатная, то действия становятся более свободными, не привязываются к количеству воды.

Развитие рынка специализированных ёмкостей - бутылок, кружек, термосов для воды - также оказало влияние на практики российских информантов. Модные, необычные и привлекательные, эти ёмкости позволяют пить воду в любое время независимо от места и удалённости от магазина или природного источника воды.

Ну, они очень красивые на вид, на самом деле. У них такой минималистский дизайн, красиво выглядят, реально (Нина, 20 лет).

Ещё одну «маркетинговую» причину увеличения популярности воды респонденты видят в том, что посылы о значимости питьевой воды широко рассеяны в информационном пространстве. Не только производители бутилированной воды, но, например, и поставщики косметики продвигают чистую воду, пытаясь привлечь внимание к своей продукции.

При этом она (Любимая модель информанта. - Авторы.) недавно стала лицом Bioderma. Bioderma - это фирма, которая у меня ассоциируется с водой, и это тоже как-то очень повлияло (Яна, 22 года).

Также было замечено, что сегодня происходит приравнивание воды к другим напиткам администрацией ресторанов. Вода встала в ряд с чаем, кофе, соком, газировкой и даже пивом и алкоголем. Одним из индикаторов, в частности, является институционализировавшийся запрет на внос воды в заведения, куда раньше нельзя было входить только со своими напитками:

Один неприятный момент был, когда в «Якитории»нам сказали, что со своим нельзя, хотя мы были с водой простой. Не с алкоголем, не с кока-колой, а с водой (Нина, 20 лет).

В рамках реализации программы по охране труда в Трудовой кодекс РФ в 2012 г. был внесен ряд поправок, которые стимулировали работодателей развивать культуру здорового образа жизни на рабочем 
месте и вне его [Паутов, Паутова 2014]. Практики потребления воды некоторых информантов также зависят от работы: им выдаётся корпоративная вода, им легче контролировать потребление воды во время работы, они не переплачивают за воду, так как им не приходится покупать её в магазинах, им не нужно нести её из дома и т. д. Можно сказать, что в таких случаях ценности и привычки людей формируются под контролем работодателей.

\section{«За живой и мёртвой водой»: «пригодность» воды в индивидуальном потреблении}

Для того чтобы понять, каким образом вода воспринимается информантами, мы проанализировали, в каких категориях она мыслится респондентами. Дискурс имеет преимущественно положительную коннотацию: «чистая», «живая», «прозрачная», «свежая», «полезная». Характеризуя воду, информанты прибегают к эмоционально окрашенным прилагательным, метафорично выражая наличие символических смыслов, глубинных аттитюдов, которые сложно отрефлексировать иным образом.

Как уже было сказано, тема чистоты воды красной нитью пронизывает интервью. Безопасность воды связывается с отсутствием в ней бактерий и «вредных примесей».

У меня, например, у лучшей подруги вся семья пьёт воду из-под крана, а меня аж передёргивает от этого; мне кажется, она такая грязная и невкусная (Валерия, 21 год).

Однако питьевая вода нагружена и глубокими смысловыми категориями, связанными с духовной жизнью. Респонденты практикуют общение с водой как с «живой субстанцией», верят в возможность структурирования воды и её целительные свойства, исполнение желаний, считают, что относиться к воде нужно очень корректно, положительно. Антропоморфизм проявляется и в том, какими качествами они её наделяют и как с ней взаимодействуют.

Я когда воду пью, я с ней разговариваю. И, если мне надо что-то загадать, попросить, то я поливаю себя душем. И всегда это материализуется (Маргарита, 44 года).

Респонденты в интервью самостоятельно выходят на беседу о «святой воде». Они уверены, что это вода полна энергии и лечебной силы, поэтому считается, скорее, «исключительнылм продуктом», который нужно пить в праздники, во время болезни и в других редких случаях. Не нарушать священность церковной воды стремятся в том числе и люди, которые не определяют себя как воцерковлённые или высокорелигиозные.

Например, гормональные таблетки, я никогда их не запью святой водой. Я хоть и не суперрелигиозная, но так всё равно никогда не сделаю (Яна, 22 года).

Анализ нарративов позволяет выявить целый ряд инструментов, к которым прибегают информанты в попытках повысить качество питьевой воды. Заметим, что эти инструменты подчас носят не столько рациональный, сколько мистический характер.

Государственные очистные сооружения для водопроводной воды не пользуются безусловным доверием. По мнению информантов, качество воды после такой очистки является неудовлетворительным. Весьма часто упоминаемой практикой оказываются кипячение и использование различных водоочистных фильтров. Хотя качество воды и в данном случае ставится под сомнение: ...она пахнет всё равно не так (Ирина, 21 год). Альтернативу кипячению и фильтрации некоторые респонденты видят в замораживании воды, полагая, что это значительно улучшает её качество и помогает избавиться от бактерий: 
Она (Бабушка. - Авторы.) берёт большую кастрюлю, наливает в неё воду из-под крана и потом ставит её в морозилку. На следующий день она достаёт эту кастрюлю, пробивает лёд, выливает эту воду в раковину и размораживает этот лёд, и эту вот воду уже пьёт (Валерия, 21 год).

Особняком стоят практики, призванные воздействовать не столько на химические, сколько на «энергетические» аспекты питьевой воды. Россияне, в том числе и высокообразованные, разговаривают с водой, чтобы повлиять на её структуру и сделать «более дружественной», настаивают воду на камнях и минералах:

Есть некоторые вещчества, например камни, которые при помещеени в воду её структурируют, и она становится живой (Михаил, 41 год).

Примечательно, что если вода из-под крана может восприниматься как непригодная для питья, то вода из природных источников, напротив, ассоциируется с высоким качеством:

Я на 100 прочентов уверен, что вода из родника абсолютно чистая (Михаил, 41 год);

А как бы из родника - да, я пила. В рамках такого...единения с природой (Мария, 22 года).

Отдельной задачей исследования была идентификация критериев оценки качества питьевой воды, коммуницируемых рынком бутилированной воды. Темой для обсуждения в интервью стало соотношение характеристик предлагаемой воды с её денежной стоимостью. Так, при обсуждении примеров завышения цен на бутилированную воду проявилось убеждение, что в отношении «очищенной, но всё-таки водопроводной» воды оно никак не может быть оправдано. Тем не менее переход питьевой воды в стадию рыночного продукта устраивает москвичей, так как рынок даёт некий надёжный ориентир относительно качества воды, чему способствуют ГОСТы и производители. Покупать воду «за копейки» считается неприемлемым, поскольку в этом случае непонятно, были ли вообще затрачены деньги на обработку воды или же они пошли только на упаковку:

В данном случае бренд, марка - это твоя гарантия, что твоя вода не из ближайшего унитаза была налита, только на это нам и остаётся рассчитывать (Нина, 20 лет).

Необходимо отметить, что у некоторых информантов доверие к государственным источникам исследований выше, чем к коммерческим; есть и те, которые предпочитают читать информацию только независимых организаций.

Также качество воды может стабилизироваться в глазах потребителей, если речь идёт о воде для определённых групп населения. Например, некоторые склонны выбирать специализированную воду, предназначенную для детей. По их мнению, она отличается от другой воды высоким качеством, наличием минералов, ей можно доверять:

Ну, и мне почему-то кажется, что люди, которые делают что-то для детей, они не будут химозное делать, потому что таких людей сажать надо, если они это реально делают (Нина, 20 лет).

\section{Om качества к количеству: калькуляция как аспект управления питьевым режимом}

В ходе рационализации каждый аспект человеческого действия становится предметом расчёта, измерения и контроля. Анализируя практики информантов по потреблению питьевой воды, мы пришли к 
выводу, что данный аспект довольно ярко проявляется в процессе повседневной человеческой жизни. Кажется довольно противоречивым тот факт, что люди не просто пьют воду, а стремятся к потреблению её в определённых количествах, к соблюдению при этом временных интервалов и просчитыванию самого процесса. Такое обыденное, физиологически необходимое и естественное действие, как питье воды, подвергается управлению через расчёт.

Нормы потребления воды задаются социально и подвергаются соответствующему контролю:

Удобно, когда ты идёшь и берёшь три бутылки воды на работе, и на тебя не смотрят как на сумасшедшую. Но есть, в принщипе, у меня есть люди, которые тоже сразу набирают три бутылки воды или четыре. У нас есть люди, которые таскают по пять, и на них все смотрят как на нахлебников. Но в целом по две бутылки берут очень многие (Мария, 22 года).

«Правильное» потребление воды у информантов ассоциируется с необходимостью чётко знать «когда, в какое время, какое количество» и всё «вымерять», с поиском «здорового баланса» воды для своего организма, качеством воды.

«Неправильное» потребление отражается в «необычном», «несоизмеримом» (слишком большом или слишком маленьком) для себя количестве воды и нерегулярности потребления.

Подсчёт количества потребляемой воды напрямую зависит от того, что именно информанты понимают под водой - любую жидкость или только чистую воду. К жидкости приравниваются все напитки (чай, кофе, газированная вода), а также супы, фрукты, которые идут в общий учёт потребляемого объёма жидкости в день. Когда же говорят о чистой воде, то подразумевают воду «без примесей», в том числе и без газа.

Сам объём воды калькулируют более крупно - через ёмкости, в которую обычно наливают воду (например, бутылки, кружки, стаканы), или более мелко - подсчётом глотков. Возможно, это связано с тем, что люди в повседневной жизни склонны всё упрощать и не проводить сложных математических операций в уме, поэтому им удобнее считать количество потребляемой воды именно таким образом, то есть используя лишь операции сложения и вычитания.

$$
\text { Я знаю, что стакан воды с утра - это примерно } 250 \text { мл (Мария, } 22 \text { года). }
$$

Несмотря на то что сложных математических операций, считая количество воды, люди, как правило, не делают, они используют мысленные расчёты как способ калькуляции, который подразумевает простые математические операции сложения и вычитания:

Когда я прихожу на работу, я... Сейчас это и вправду легче считать, потому что у нас стоят бутылки с водой на кухне на работе, я могу спокойно брать сколько угодно. Я обычно беру себе на стол две бутылки. Ну, вот две я выпиваю в первой половине дня. И потом я либо иду и беру третью, если она ещее там осталась, если не все растащили с кухни. Либо, если её там уже нет, я иду и доливаю себе третью. То есть три бутылки я точно выпиваю, когда сижу вот просто в офисе. Потом, когда я еду на учёбу или, не дай бог, на спорт, то я с собой опять же либо наливаю, либо беру ещё одну, получается, четвёртую бутылку. И вот выпиваю её, и получается, что, например, в пять часов с работы ухожу и выпиваю. И это вот точное количество, которое я могу назвать и могу действительно посчитать (Мария, 22 года). 
Калькуляция проявляется и в процессе учёта временных промежутков и времени суток при потреблении воды: время между потреблением еды и воды, потреблением воды во время спорта и питьём в течение суток, а именно натощак, в первой и второй половине дня, вечером и ночью:

Первое, что я делаю, когда просыпаюсь, - это выпиваю стакан водыл. Потом я стараюсь сделать какую-то небольшую зарядку и иду завтракать. Собственно, вот эти 15 минут это для того, чтобы соблюсти какой-то определённый промежуток времени между приёмом воды и приёмом пищи. Собственно, я могу, наверное, ещзё выпить стакан воды после завтрака и стараюсь соблюдать перерыв где-то 15-20 минут. Вообще в течение дня я достаточно часто пью воду и стараюсь придерживаться какого-то такого принциип, выпивать как минимум два литра водь в день. Причём делать это тоже в первой половине дня, часов до трёх я выпиваю литра полтора уже и немного вечером. Раньше я пыталась догнать количество до двух литров, так как я в течение дня могла не выпить нужное количество, и делала это вечером. Тогда я просыпалась опухшая с запльвшими глазами и как-то поняла, что это не очень хорошая идея. Поэтому сейчас это всё происходит в первой половине дня (Мария, 22 года).

Установки на изменение потребления определённого количества воды могут быть как краткосрочными (например, в течение одного определённого дня), так и долгосрочными. Долгосрочные установки предполагают возведение практик потребления установленного количества воды в день в привычку.

\section{Конструирование питьевого режима: от привычки к потребности}

Описание того, как изменялись практики потребления воды, хорошо укладываются в теоретический концепт «опривычивания» [Бергер, Лукман 1995]. Исходя из воспоминаний информантов, можно судить, что было время, когда их практики существенно отличались от тех, которые они используют сейчас:

В детстве... я не обращуала внимания. Из взрослых тоже никто на этом не акцентировал внимания (Нина, 20 лет).

Я раньше могла пить очень мало. То есть я пила кофе, чай, в умеренных количествах воды могла выпить, стакан, например... Сейчас я понимаю, что это неправильно (Юлия, 21 год).

И вообще, я как-то об этом не думала, мне пить не хотелось и было комфортно (Мария, 22 года).

Мы видим, что до какого-то момента информанты пили воду в малом количестве и при этом чувствовали себя комфортно, особо не размышляли на тему потребления питьевой воды, возможных последствий, пользы и вреда её употребления. Однако затем, в какой-то критический момент (critical point - термин информанта), они решили изменить свои практики. При этом некоторым пришлось столкнуться с трудностями:

Всё равно было как-то тяжеловато выпивать два литра, это было первоначально сложно (Дарья, 22 года);

Это тяжело, но привыкаешь (Ирина, 21 год).

Другим же вообще не удаётся этого сделать: 
Она себя заставляет, но у неё не получается (Яна, 22 года);

Понимаю, что это неправильно, но не могу ничего с этим поделать (Нина, 20 лет);

Но у меня столько не получается пить чистой водьг <... >. Для организма требуется больше, чем я пью чистой воды (Екатерина, 49 лет).

Информанты отслеживают количество потребляемой воды, создавая внешние условия, фактически принуждающие их выпить необходимую норму. Так, например, наличие заранее купленной и налитой бутылки «nеред глазами» значительно упрощает достижение поставленных целей. Иногда приходится иметь при себе несколько бутылок - в офисе, в машине.

Можно поставить бутылку перед собой. Когда стоит бутылка, ты уже ненароком её пьёшь, а когда рядом с тобой вообще нет воды, ты не вспоминаешь о ней (Ирина, 21 год);

Просто стараюсь на виду всегда держать бутылку (Нина, 20 лет).

Вода, таким образом, сама напоминает о себе. Логика этой стратегии проста: увидел воду и сразу вспоминаешь о том, что нужно её выпить. Кроме того, фраза информанта «ненароком её пьёшь» показывает: наличие воды «под рукой» может содействовать тому, что действие будет выполняться «на автомате», а это одна из составляющих привычки. Возможно, что через какое-то время напоминания о «водной стихии» (бутылки, кулеры, стаканы с водой и т. д.) в дизайне среды перестанут привлекать внимание и будут восприниматься лишь как фон. Можно предположить, что человек акцентирует внимание на питьевой воде и всём, с нею связанным, поскольку это важно для него. Особую значимость подобная внимательность имеет на этапе, когда потребление воды ещё не стало привычным.

По словам информантов, особое значение имеет доступ к воде в течение всего дня. Так повышается вероятность того, что человек сделает лишний глоток или два. В качестве рекомендаций поэтому выступает необходимость брать бутылку с собой везде, в том числе в дорогу:

И опять же бутылка с собой - очень действенный метод (Ирина, 21 год);

Я набирала с собой поллитровку воды дома, знала, что в течение дня я должна её осушить (Юлия, 21 год).

Стратегия «брать бутылку с собой везде»- в некотором роде частный случай стратегии «бутылка на виду». Однако мы выделим её отдельным кодом, потому что наиболее важным моментом здесь является не напоминание себе о том, что надо пить воду, а попытка обеспечить доступ к питьевой воде в течение всего дня. При этом основное - размер тары, позволяющий обеспечить доступ к сравнительно большему количеству воды в каждый момент в течение дня:

Я специально иногда покупаю больщие бутылки и ношу их с собой в институт (Яна, 22 года).

Если цель не состоит только в потреблении большого объёма воды, а задаётся ежедневная норма потребления, возникает возможность заранее подготовить весь объём и обеспечить доступ к этой воде в течение дня:

Старалась покупать две бутылки воды, по литру. И старалась пить в течение дня (Яна, 22 года). 
Описанные тактики решают проблему необходимости калькуляции количества выпитой воды: в конце дня становится понятно, получилось ли выпить необходимое количество воды.

Для того чтобы выпить воду вовремя, можно также использовать разные способы напоминания:

Я пыталась пользоваться приложением, которое должно было напоминать о том, что нужно опять выпить... (Яна, 22 года);

Кому-то нужно ставить будильники, напоминалки (Юлия, 21 год);

С этими приложениями как-то стало прощее. Это вносит определённую дисциплину в твою жизнь (Дарья, 22 года);

Можно там себе поставить напоминание по поводу воды, потому что телефон просматриваем каждую секунду. Если будет написано на экране: «Вода», - почему бы и нет (Ирина, 21 год).

Выше шла речь о том, что бутылка с водой перед глазами бутылку сама напоминает о себе. Использование специализированных, то есть предназначенных для контроля потребления воды, приложений, а также базовых (обычный будильник тоже может использоваться в качестве напоминания) технических приложений реализует функцию напоминания. Очевидным преимуществом первых является то, что они будут не просто напоминать о необходимости пить воду, но также сделают это в «нужное», а не в произвольное, то есть «по зову организма», время. В этом смысле такие приложения более эффективны, нежели тактика «бутылка на виду». Интересно отметить, что респонденты высоко оценивают важность воды для функционирования организма и, отрицая все приёмы калькуляции, знают точно, но априори, что выпивают достаточное количество воды.

Теперь вернёмся к тому, как проявляется потребность пить воду. Использование технических приспособлений для напоминания являет собой, по сути, попытку добавить внешний контроль, чтобы дисциплинировать себя. Изменяя практики, люди не просто добровольно позволяют себя контролировать, но сами создают условия для внешнего контроля.

Однако существует мнение, что такой контроль не всегда эффективен:

Потом я от них отказалась. Почему? Как только есть дисциплина в твоей жизни, ты привыкаешь к этому... Как только эта дисциилина и, скажем так, внешний контроль исчезают, ты возвращаешься к своим прежним привычкам <... >. Я поняла, что, наверное, лучше сточт слушать себя и стараться самой. То есть не с помощью какой-то программы, которая будет тебе говорить: «Вам пора поесть, Вам пора выпить водччки», - а вносить именно сознательность в культуру питания (Дарья, 22 года).

Речь, видимо, идёт о том, что внешний контроль не должен заменять внутренний. Ведь в этом случае возникает зависимость от внешнего воздействия, а его отсутствие приведёт и к отсутствию результата. По словам информанта, необходимо привнести «сознательность» в процесс; новый питьевой режим должен стать внутренней потребностью.

Стратегией можно назвать и попытки обеспечить плавный переход от старых к новым привычкам: 
Начинала я, по-моему, с газированной воды, потому что до этого я пила только там эти соки или кока-колу... Потом перешла постепенно на газированную воду, а потом уже на обычную (Ксения, 20 лет).

Таким образом, простая газированная вода выступила переходной ступенью между соками и сладкой газированной водой. Очевидно, что непросто переключиться с одних практик потребления на другие, ведь для того чтобы изменить свой привычный уклад, необходимо попрощаться с предыдущим рутинным опытом. Данное рассуждение также позволяет нам понять особенность хабитуализации: это процесс, который требует того или иного количества времени.

В ту же логику укладывается и следующее суждение: чтобы пить достаточное с нормативной точки зрения количество воды, необходимо поддерживать потребление на определённом уровне. Хорошим же началом выступают условия, в которых возникает естественная потребность пить больше воды (например, легко изменить свои потребительские практики летом, когда жарко):

Мне кажется, что легко привыкнуть пить воду с утра, летом особенно. Когда жарко, когда тепло, мне кажется, утром просыпаешься, так и хочется выпить холодной водички (Софья, 64 года).

Таким образом, используя принцип открытого кодирования, можно выделить следующие стратегии «опривычивания»:

— «бутылка с собой»;

— «бутылка на виду»;

— «большая бутылка»;

— «вода на экране» гаджета;

— «перейти постепенно».

Социально сконструированной оказывается не только потребность пить определённое количество воды, но и восприятие её вкуса:

Просто у меня есть друзья, которые реально очень много пьют воды, потому что им с детства ставили на стол стакан воды, а не стакан сока или чая, или ещё что-то. Они могут пить из-под крана, «Шишкин лес», что угодно... (Нина, 20 лет).

Аналогичным образом, на основе личных изменений практик информантов, можно проследить изменение самоощущений:

Но осознание того, что мне хорошо от воды, пришло со временем, когда я поняла, что вода лучше кока-кольл (Нина, 20 лет).

Иными словами, даже если информанту раньше становилось лучше от воды, он этого не ощущал, сейчас же «понимание» того, что вода более полезна для организма, позволяет ощущать результаты потребления. О том, как конструируется и саморефлексируется информантами польза, сказано выше; здесь нам хочется показать, что конструирование пользы является частью процесса опривычивания.

В рамках выбранного метода мы не можем посмотреть, насколько практики наших информантов преуспели в процессе хабитуализации новых практик, но можем сопоставить реальные практики с хаби- 
туализированным действием, для чего попробуем выделить сюжеты, которые согласуются с признаками привычного действия:

- повторение: информанты говорили о том, что их практики в целом не изменяются день ото дня; существует питьевой режим, которого им удаётся придерживаться. Индикатором повторяемости является использование информантами слов «каждый», «всегда»;

- автоматизированность: схема потребления стала настолько привычной, что информанты уже не задумываются, не акцентируют внимание на том, как они пьют воду, делают это на автомате;

- механизированность: информация о том, как информанты пили воду за день до интервью, содержит конкретную последовательность действий с указанием промежутка времени между шагами, это в том числе проявляется утром, сразу после пробуждения (от пробуждения до выхода из дома есть конкретная система действий).

Вышесказанное может быть приложимо не ко всем информантам. Мы рассматривали кейсы, когда человек пьёт мало воды (относительно общей нормы), никак не контролирует своё потребление и не собирается ничего менять в ближайшем будущем. Но более интересны случаи, когда группы информантов отрицали то, что они контролируют каким-либо образом количество потребляемой воды, но при этом пьют много воды. Объясняли они это своей потребностью - жаждой, желанием пить. Для некоторых из них подсчёт литража был настолько неестественным, что наши вопросы казались им бессмысленными:

Интервьюер: А Вылично следите за тем, сколько нужно потреблять воды в день?

Респондент: Нет, не слежу.

$<\ldots>$

Интервьюер: А относительно количества водь?

Респондент: Количества воды ? <..> Хочет организм два литра воды - пей два литра воды. Не хочет вообще - не пей (Елизавета, 22 года).

При этом интересно, что некоторые информанты высоко оценивают важность воды для функционирования организма и, отрицая все приёмы калькуляции, знают априори, что выпивают достаточное количество воды.

Вернёмся к тому, как проявляется потребность пить воду:

Сейчас я пью воду, потому что мне хочется пить. То есть мне действительно некомфортно, если я выпила за один день всего один стакан утром. Я действительно чувствую жажду (Мария, 22 года);

Потом как-то я втянулась, и сейчас мне действительно некомфортно, если я не пью хотя бы полтора литра. Я прямо умираю, иду в магазинь, мне сразу надо купить воду (Мария, 22 года);

И у меня прямо потребность, жажда, которая может быть даже сильнее, чем голод, по ощущениям (Яна, 22 года).

Из данных рассуждений видно, что потребность, которую чувствуют информанты, имеет большое влияние на них. Яркие сравнения: «умираю», «сильные ощущения», которые используют информанты, 
свидетельствуют о том, что практики потребления воды были автоматизированы и механизированы в такой степени, что привычка пить воду воспринимается как потребность. При этом необходимость контроля отпадает, так как альтернативы нет: они просто не могут поступить по-другому; иное поведение им кажется неестественным, на грани невозможного.

Необходимо помнить о том, что практика потребления питьевой воды - это часть системы рутинных практик. Такой угол рассмотрения позволяет нам убедиться в том, что выбор той или иной практики потребления воды тянет за собой «вереницу» действий, её обслуживающих. На основе рассказа о том, как отец осуществляет смену картриджа фильтра-кувшина, мы можем охарактеризовать это действие как рутинизированное или опривыченное:

У него это просто налаженная система. Он не пишет об этом на ладошке, чтобы не забыть, он просто помнит об этом, как и о многих других вещзах, поэтому у него с этим нет проблем (Надежда, 20 лет).

Отвечая на вопрос, о том, как часто приходится покупать воду в магазине, одна из информанток ответила:

Каждый день, раз в два дня, где-то так (Надежда, 20 лет).

Таким образом, поход в магазин за водой является ежедневным ритуалом, неотъемлемой практикой рутины человека. Речь идёт и о «повторяемости», которую мы также фиксировали в практиках питья. При описании индивидуального и институционального изменения в практиках необходимо понимать системность рутинных действий.

\section{Заключение}

Предпринятое исследование практик потребления питьевой воды позволяет проиллюстрировать, что рационализация проникает в повседневную жизнь людей, переводя такие обыденные физиологические действия, как утоление жажды, в режим дисциплинарного самоконтроля. Самоконтроль осуществляется через конструирование необходимых для государства дискурсов и представление их в качестве полезных для индивидов. Рационализация повседневности возникает в результате влияния культурных, экономических, институциональных условий, и, как следствие, формируются смысловые категории и калькулятивные механизмы, которые определяют практики, хабитуализируемые индивидами.

Так, увеличение поступающей информации о здоровом образе жизни и «правильном» потреблении воды из социальных сетей, социального окружения, референтных групп информантов, от государственных деятелей, медицинских работников, научных организаций, родителей и из рекламы способствует рефлексии на тему здоровья и режима питания. Контроль, осуществляемый институтами, задаёт определённые каноны поведения, которые воспринимаются индивидами как собственные осознанные действия. Уходя от обыденных физиологических потребностей, люди начинают приписывать социальные смыслы полезности, вкусу, желаниям и внешности. Практики потребления воды теперь определяются медицинскими исследованиями, нормами и «правильными» пропорциями тела, морализаторским отношением к телу и здоровью, религиозными смыслами, государственным вмешательством в распорядок жизни людей, которое осуществляется через работодателей, науку, рынок, создание школ «идеального тела» и другие институты.

Потребление питьевой воды позволяет создавать социальные идентичности групп людей (например, «ППшники»). Потребление воды становится одним из способов достижения «хорошей внешности». 
Акцент на тело и телесность становится характеристикой современного общества, а вода - одним из средств достижения определённого статуса в обществе. Мода на диеты плавно переходит к популяризации моды на здоровое питание и худое тело, что в рамках феномена хелсизма может улучшить здоровье граждан и увеличить благосостояние государства в целом. Отсутствие ожирения, заболеваний, связанных с сердцем и с сосудистой системой, вероятно, даёт возможность государству экономить средства, затрачиваемые на медицину, а работодателям — на обеспечение лечения работников. Так, в исследовании проявился феномен хелсизма и медикализации, в связи с которым, возможно, все больше сфер повседневности затрагиваются медициной и наукой.

В процессе анализа обнаружилось, что наука в сознании информантов оказывается обезличенной, поскольку нет основного источника получения научных знаний и результатов исследований. Информация достаточно разобщена, а доверие к ней формируется только благодаря тому, что она поступает из уст учёных и от лица государства. Можно сделать вывод о возникновении феномена сциентизма и о том, что у науки появляется возможность влиять на создание и практики людей, опираясь на саму себя и не будучи беспристрастной. Наука, скорее, выполняет заказ, поступающий от институциональных структур.

Люди хотят быть здоровыми и красивыми, стремятся действовать рационально для достижения этих целей, то есть контролируют своё поведение, просчитывая его и измеряя последствия, что доказывает существование калькулятивных механизмов в повседневной жизни.

Забота о качестве воды может быть рассмотрена с позиции хелсизма: навязывание представлений о здоровом образе жизни связано с тем, что государству выгоднее иметь здоровых и экономически активных граждан, способных самостоятельно позаботиться о себе, не прибегая к средствам социальной защиты. В рамках данной работы сложно проверить, используется ли представление о теле макроинститутами, чтобы управлять поведением индивидов, но рассуждения на тему телесности и государственного контроля показывают, что идея о «здоровом», «идеальном» теле оказывается для них весьма выгодной.

Процесс перехода от потребностей, реализуемых через государственный контроль, к самоконтролю сопровождается калькуляцией. Механизм контроля проявляется в действиях индивидов через рефлексию, для которой характерны установки на достижение определённых целей и осознанный учёт количественных показателей в процессе потребления воды, неосознанный подсчёт преимуществ и недостатков осуществлённого выбора, а также латентный для самого действующего индивида учёт цены, времени, качества, комфорта и количества воды.

Элементы калькулятивного поведения рассчитываются через отдельные составляющие. Цена калькулируется через необходимое количество воды, оптимальную цену за это количество, бренд питьевой воды, а также через бесплатную питьевую воду. Следующий элемент калькуляции - комфорт - оценивается исходя из ситуативности, цены, времени и объёма воды. Само время контролируется через время суток и промежутки между водой и едой, спортом и водой. Объём воды учитывается при помощи ёмкостей для воды, калорийности, ошибок потребления, специфической нормы, одобрения и привычки. Также в процессе выбора, калькулируется качество воды.

Осознавая силу опривыченных действий, выполняемых на автомате, люди пытаются искусственно хабитуализировать то, что соответствует их целям и установкам, то есть осознанно делают своё действие неосознанным. Человеку кажется, что полезно пить больше воды, даже если он не испытывает чувство жажды, поэтому он старается превратить употребление большого количества воды в привычку. При этом, как отмечалось, формирование одобряемых практик потребления воды в рамках более широкого 
процесса популяризации здорового образа жизни представляется нам тем, что М. Фуко называл «техникой себя». В результате хабитуализации практика становится опривыченной настолько, что воспринимается как потребность; это показывает, как формы биополитического контроля распространяются непосредственно на повседневность.

Обозначая ограничения нашего исследования, следует отметить, что выбор рационализации как теоретической перспективы для объяснения практик потребления питьевой воды в России является одним из возможных. В данной работе мы полностью дистанцировались от вопроса о том, в какой мере наблюдаемые различия в подходах к потреблению воды отражают классовый характер. Проблематизируя опривычивание новых практик потребления воды в России, мы опирались на феноменологическую традицию в версии П. Бергера и Т. Лукмана. Несомненно, более пристальное изучение этого вопроса с привлечением концептуального аппарата, разработанного П. Бурдьё, с его акцентами на связи между социальной принадлежностью индивидов и их вкусами, поможет в будущем существенно обогатить полученную нами картину. Кроме того, мы весьма смело опираемся на идею говернментальности М. Фуко, минуя важную дискуссию о том, в какой мере и при каких условиях работы этого автора применимы для анализа российской действительности [Мишель Фуко и Россия... 2001].

Также нельзя игнорировать тот факт, что, ставя вопрос о рационализации повседневной жизни в России, мы концентрируем внимание на весьма узком предмете - на потреблении питьевой воды. И даже эта тематика раскрывается нами на этнографическом материале. С учётом уровня внешней валидности необходимо дополнить полученные данные, используя количественные методы для создания более объёмного триангулятивного видения рассматриваемого явления.

Оставляя фокус исследовательского внимания только на жителях Москвы и ближайших городов и предполагая, что передовые практики быстрее интериоризируются именно в столице, мы также отказываемся от любых попыток генерализировать полученные выводы, распространить их на другие регионы России. В рамках будущих исследований привлекательной видится возможность сравнить практики потребления воды в столице и за её пределами, в том числе в других странах.

На наш взгляд, нам удалось показать, каким образом феномен рационализации проявляется в ежедневных питьевых практиках, однако вследствие ограниченности ресурсов не все тематические сюжеты были раскрыты. Так, дальнейшей разработки требуют символические значения воды, необходимыми представляются гендерные и территориальные исследования. Был затронут, но не получил глубокой разработки процесс трансформации нормативных установок внутри различных социальных групп. Были обозначены основные источники нормативных установок, но характер их влияния на практики не мог быть полностью раскрыт в рамках данного исследования. Исторический анализ (например, сравнение современных и советских практик), более глубокий контент-анализ современного дискурса о потреблении воды, исследование количественного дизайна с его возможностью генерализации результатов позволили бы более полно охарактеризовать описыванный нами феномен. 


\section{Приложение}

Таблицча П.1

Информация об интервью и характеристиках информантов

\begin{tabular}{|c|c|c|c|c|c|}
\hline \multirow{2}{*}{$\begin{array}{c}\text { № } \\
\text { интер- } \\
\text { вью } \\
\end{array}$} & \multicolumn{5}{|c|}{ Интересующие критерии } \\
\hline & Имя* & Род деятельности & Проживание & $\begin{array}{c}\text { Спортивная } \\
\text { деятельность }\end{array}$ & $\begin{array}{c}\text { Возраст } \\
\text { (полных лет) }\end{array}$ \\
\hline 1 & Мария & Работает, учится & Переезд в Москву & Любитель & 22 \\
\hline 2 & Илья & Работает & Москва & Любитель & 28 \\
\hline 3 & Вероника & Работает, учится & Переезд в Москву & Профессионал & 21 \\
\hline 4 & Дарья & Учится & Переезд в Москву & Любитель & 22 \\
\hline 5 & Екатерина & На пенсии, работает & Иваново & Не занимается & 49 \\
\hline 6 & Виктор & Работает, учится & Москва & Не занимается & 19 \\
\hline 7 & Михаил & Работает & Москва & Не занимается & 41 \\
\hline 8 & Татьяна & Учится & Москва & Любитель & 17 \\
\hline 9 & Алла & Работает & Москва & Не занимается & 43 \\
\hline 10 & Валерия & Работает, учится & Переезд в Москву & Любитель & 21 \\
\hline 11 & Ирина & Работает, учится & Москва & Любитель & 21 \\
\hline 12 & Ксения & Учится & Переезд в Москву & Любитель & 20 \\
\hline 13 & Ольга & Работает (тренер) & Москва & Профессионал & 41 \\
\hline 14 & Светлана & На пенсии & $\begin{array}{c}\text { Удельная, посёлок } \\
\text { городского типа }\end{array}$ & Любитель & 65 \\
\hline 15 & Елизавета & $\begin{array}{c}\text { Работает, учится } \\
\text { (тренер) }\end{array}$ & Москва & Профессионал & 22 \\
\hline 16 & Маргарита & Работает (врач) & Москва & Не занимается & 44 \\
\hline 17 & Нина & Учится & Москва & Любитель & 20 \\
\hline 18 & Надежда & Учится & Переезд в Москву & Любитель & 20 \\
\hline 19 & Юлия & Учится, работает & Москва & Любитель & 21 \\
\hline 20 & Яна & Учится & Переезд в Москву & Любитель & 22 \\
\hline 21 & Софья & На пенсии & Москва & Не занимается & 64 \\
\hline 22 & Сергей & Работает & Москва & Любитель & 50 \\
\hline 23 & Полина & На пенсии & Москва & Не занимается & 66 \\
\hline 24 & Виталий & На пенсии, работает & Москва & Не занимается & 72 \\
\hline 25 & Андрей & Работает, учится & Москва & Не занимается & 23 \\
\hline 26 & Максим & Работает, учится & Переезд в Москву & Любитель & 23 \\
\hline
\end{tabular}

* Для сохранения конфиденциальности информации все имена являются вымышленными.

\section{Литература}

Бабурин В. Л., Земцов С. П. 2013. География инновационных процессов в России. Вестник Московского университета. Серия 5: География. 5: 25-32.

Бандурин А. П., Бандурин В. А. 2015. Социальная рациональность в знаниевом контексте повседневности современного общества. Гуманитарные, социально-экономические и общественные науки. 3 : $13-17$. 
Бергер П., Лукман Т. 1995. Социальное конструирование реальности. Трактат по социологии знания. Пер. Е. Руткевич. М.: Медиум.

Бек У. 2000. Общество риска: на пути к другому модерну. Пер. В. Седельник, Н. Федорова. М.: Прогресс-Традиция.

Вальденфельс Б. 1991. Повседневность как плавильный тигль рациональности. В сб.: Соџио-Логос: соииология, антропология, метафизика. Вып. 1. Общество и сферы смысла. М.: Прогресс; 39-50.

Вебер М. 1994. Избранное. Образ общества. М.: Юрист.

Вебер М. 2007. История хозяйства. Биржа и её значение. М.: Гиперборея; Кучково поле.

Вебер М. 2016. Хозяйство и общество. Очерки понимающей соџиологии. Пер. с нем. М.: Издательский дом ВШЭ.

Водный баланс организма. 2016. kaula.ru. URL: http://www.kaula.ru/meropriyatiya/17-12_seminar-vodnyibalans-organizma.

Дуглас М. 2000. Чистота и опасность. Анализ представлений об осквернении и табу. Пер. с англ. Р. Громовой, под ред. С. Баньковской. М.: Канон-пресс-Ц; Кучково поле.

Дуглас М. 2007. Окружающая среда и риск. Социиологическое обозрение. 3: 37-48.

Как заставить себя выпивать норму воды в день, 8 проверенных советов. 2015. svetlana-dolgih.ru. URL: http://svetlana-dolgih.ru/kak-pravilno-pit-vodu/

Каллон М., Меадель С., Рабехарисоа В. .2008. Экономика качеств. Пер. Г. Б. Юдина. Журнал социологии и соииальной антропологии. 11 (4): 59-87.

Ковалёв Е. М., Штейнберг И. Е. 1999. Качественные методы в полевых социологических исследованиях. М.: Логос.

Ковалёва А. А. 2008. Самосохранительное поведение в системе факторов, оказывающих влияние на состояние здоровья. Журнал социологии и социальной антропологии. 11 (2): 179-191.

Корбин Д., Страусс А. 2001. Основы качественного исследования: обоснованная теория, процедуры и техники. Пер. с англ. и послесловие Т. С. Васильевой. М.: Эдиториал УРСС.

Мишель Фуко и Россия. Сб. статей. Под ред. О. Хархордина. СПб.: Европейский университет в СанктПетербурге; М.: Летний сад, 2001.

Морено Я. Л. 2001. Психодрама. Пер. с англ. Г. Пимочкиной, Е. Рачковой. М.: Апрель Пресс; ЭКСМОПресс.

Паутов И., Паутова Н. 2014. Продвижение здорового образа жизни как инструмент реализации государственной политики в сфере охраны здоровья в современной России. Журнал исследований социальной политики. 12 (4): 493-508. URL: http://www.aup.ru/books/m245/6_3.htm 
Ритцер Дж. 2011. Макдональдизация общества. Пер. А. Лазарева. М.: Праксис.

Рынок бутилированной воды. Текущая ситуация и прогноз 2016-2020 гг. 2016. Alto Consulting Group. URL: $\quad$ http://alto-group.ru/otchot/marketing/361-rynok-butilirovannoj-vody-tekushhaya-situaciya-iprognoz-2014-2018-gg.html

Рощина Я. М. 2016. Стиль жизни в отношении здоровья: имеет ли значение социальное неравенство? Экономическая сочиология. 17 (3): 13-36. URL: https://ecsoc.hse.ru/2016-17-3.html

Слейтер Д. 2008. Забирая рынок у экономистов. Экономическая соииология. 2 (9): 29-45. URL: https:// ecsoc.hse.ru/2008-9-2.html

Фуко М. 1998. История сексуальности III: забота о себе. Пер. с франц. Т. Н. Титова и О. И. Хома, под общ. ред А. Б. Мокроусова. Киев: Дух и литера; Грунт; М.: Рефл-бук.

Фуко М. 1999. Надзирать и наказывать. Рождение тюрьмы. Пер. с франц. В. Наумова. М.: AdMarginem.

Фуко М. 2007. Психиатрическая власть. Курс лекиий, прочитанных в Коллеж де Франс в 1973-1974 учебном году. Пер. с франц. А. В. Шестакова. СПб.: Наука.

Фуко М. 2008. Технологии себя. Логос. 2 (65): 96-122.

Штомпка П. 2009. В фокусе внимания повседневная жизнь. Новый поворот в социологии. Социологические исследования. 8: 3-13.

Элиас Н. 2001. О процеессе цุивилизащии. М.; СПб.: Университетская книга.

Crawford R. 1980. Healthism and the Medicalization of Everyday Life. International Journal of Health Services. 3 (10): 365-388.

Facts and Trends: Water. 2016. unwater.org. URL: http://www.unwater.org/downloads/Water_facts_and_ trends.pdf

Ferrier C. 2001. Bottled Water: Understanding a Social Phenomenon. AMBIO: A Journal of the Human Environment. 30 (2): 118-119.

Global Packaged Water Consumption to Overtake Carbonates in 2015. 2015. canadean.com. URL: http:// www.canadean.com/news/global-packaged-water-consumption-to-overtake-carbonates-in-2015/

Global Water Demand. 2015. Facing the Challenges. Case Studies and Indicators. Unesco's Contribution to the United Nations World Water Development Report. URL: http://unesdoc.unesco.org/ images/0023/002321/232179E.pdf

iDrink. 2014. ITunes Preview. URL: https://itunes.apple.com/ru/app/idrink-lucsij-treker-vody/ id953796261? $\mathrm{mt}=8$

Kahneman D., Tversky A. 1974. Judgment under Uncertainty: Heuristics and Biases. Science. 185 (4157): 1124-1131. 
Linton J. 2010. What is Water? The History of a Modern Abstraction. Vancouver; Toronto: UBC Press.

My Bottle. 2015. my-bottles.ru. URL: http://my-bottles.ru/

Northcote M., McIntosh A. 1999. What Mathematics do Adults Really Do in Everyday Life? Australian Primary Mathematics Classroom. 4 (1): 19-21.

Ph-метр. 2017. Ismer.ru. URL: http://ismer.ru/products/ph-metr-kl-009ii?utm_source=google\&utm medium $=$ cpc\&utm_term $=\mathrm{ph} \% 20 \% \mathrm{D} 0 \% \mathrm{BC} \% \mathrm{D} 0 \% \mathrm{~B} 5 \% \mathrm{D} 1 \% 82 \% \mathrm{D} 1 \% 80 \& u t_{\text {_campaign }}=\mathrm{msk}$ _g_ph_ poisk

Trentmann F., Taylor V. 2005. From Users to Consumers - Water Politics in Nineteenth Century London. In: Trentmann F. (ed.) The Making of the Consumer: Knowledge, Power and Identity in the Modern World. Oxford: Berg Publishers; 53-79.

Verplanken B., Faes S. 1999. Good Intentions, Bad Habits, and Effects of Forming Implementation Intentions on Healthy Eating. European Journal of Social Psychology. 29 (5-6): 591-604. 


\section{DEBUT STUDIES}

\section{Anastasia Andreeva, Julia Klimeshova, Maria Kudryavtseva, Anastasia Lobanova Rationalization of Modern Life: The Case of Water Consumption in Moscow}

\author{
ANDREEVA, Anastasia - BA \\ Student, Faculty of Social Sciences, \\ National Research University \\ Higher School of Economics. \\ Address: 20 Myasnitskaya str., \\ Moscow, 101000, Russian \\ Federation.
}

Email: aaandreeva_2@edu.hse.ru

KLIMESHOVA, Julia - BA

Student, Faculty of Social Sciences, National Research University Higher School of Economics. Address: 20 Myasnitskaya str., Moscow, 101000, Russian

Federation.

Email: klimeshova.yuliya@gmail. com

KUDRYAVTSEVA, Maria - BA Student, Faculty of Social Sciences, National Research University Higher School of Economics. Address: 20 Myasnitskaya str., Moscow, 101000, Russian Federation.

Email: makudryavtseva_1@edu. hse.ru

LOBANOVA, Anastasia - BA Student, Faculty of Social Sciences; Research Assistant, Laboratory for Science and Technology Studies, National Research University Higher School of Economics. Address: 20 Myasnitskaya str., Moscow, 101000, Russian Federation.

Email: aplobanova@edu.hse.ru

\section{Abstract}

In a risk society, healthism, medicalization, and the expansion of the market for bottled water all contribute to the disciplinary self-management of drinking water consumption. Such changes align with the predictions of classical sociologists like Weber and Simmel that the phenomenon of rationalization would extend to all spheres of society, including everyday life. Based on qualitative research data on drinking water consumption in Moscow, this study assesses how such trends are manifested in contemporary Russian society.

The study demonstrates an increasing emphasis on managing thirst. In certain social contexts (including sports, weight loss, and pregnancy), the habitualization of socially constructed norms of water consumption has transformed these into an internal need. The mechanisms of control and calculative behavior are manifested in both the conscious attempts and unconscious measuring tactics developed by Muscovites to increase the volume of water being drunk. Ordinary people who are anxious about the safety of drinking water seek institutional support from the state, advertisements for bottled water, and expert knowledge of various kinds. Because the quality of drinking water is perceived to be an existential issue, the lack of certainty around this issue sometimes gives rise to irrational beliefs. The researchers were especially surprised to find references to "life-giving" or "dead" water in the narratives of respondents with a university education, including some with medical degrees.

Keywords: rationalization; disciplinary control; everyday life; calculation; habitualization; medicalization; healthism; institutional regulation; water quality.

\section{Acknowledgements}

The authors express special gratitude to the anonymous reviewers for valuable comments that enhanced the paper's quality, and to their research advisor Elena Berdysheva for help and useful comments at all stages of the research. 


\section{References}

Baburin V., Zemtsov S. (2013) Geografiya innovatsionnykh protsessov v Rossii [Geography of Innovation Processes in Russia]. Bulletin of Moscow University, vol. 5, pp. 25-32 (in Russian).

Bandurin A., Bandurin V. (2015) Sotsial'naya ratsional'nost' v znanievom kontekste povsednevnosti sovremennogo obshchestva [Social Rationality in the Knowledge Context of Everyday Life in Modern Society]. Humanities, Social-Economic and Social Sciences, no 3, pp. 13-17 (in Russian).

Beck U. (2000) Obshchestvo riska: Na puti k drugomu modernu [Risk Society: Towards a New Modernity] (Transl. V. Sedelnik, N. Fedorov), Moscow: Progress-Traditsiya (in Russian).

Berger P., Luckmann T. (1995) Sotsial'noe konstruirovanie real'nosti: traktat po sotsiologii znaniya [The Social Construction of Reality: A Treatise in the Sociology of Knowledge], Moscow: Medium (in Russian).

Callon M., Meadel C., Rabeharisoa V. (2008) Ekonomika kachestv [The Economy of Qualities] (Transl. G. B. Yudin). The Journal of Sociology and Social Anthropology, vol. 11, no 4, pp. 59-87 (in Russian).

Corbin D., Strauss A. (2001) Osnovy kachestvennogo issledovaniya: obosnovannaya teoriya, protsedury $i$ tekhniki [Qualitative Research Method: Grounded Theory] (Transl. T. S. Vasilieva), Moscow: Editorial URSS (in Russian).

Crawford R. (1980) Healthism and the Medicalization of Everyday Life. International Journal of Health Services, vol. 3, no 10, pp. 365-388.

Douglas M. (2000) Chistota i opasnost'. Analiz predstavlenij ob oskvernenii i tabu [An Analysis of the Concepts of Pollution and Taboo] (Transl. R. Gromova, ed. S. Bankovskaya), Moscow: Kanon-press-Ts, Kuchkovo pole (in Russian).

Douglas M. (2007) Okruzhayushchaya sreda i risk [An Analysis of the Concepts of Pollution and Taboo]. Sotsiologicheskoe obozrenie, vol. 6, no 3, pp. 37-48 (in Russian).

Elias N. (2001) O protsesse tsivilizatsii [The Civilizing Process], Moscow; St. Petersburg: Universitetskaya kniga (in Russian).

Facts and Trends: Water (2016) Available at: http://www.unwater.org/downloads/Water_facts_and_trends.pdf (accessed 7 March 2017).

Ferrier C. (2001) Bottled Water: Understanding a Social Phenomenon. AMBIO: A Journal of the Human Environment, vol. 30, no 2, pp. 118-119.

Foucault M. (2007) Psikhiatricheskaya vlast'. Kurs lektsiy, prochitannykh v Kollezh de Frans v 1973-1974 uchebnom godu [Psychiatric Power. Lectures at the College de France 1973-1974] ( Transl. A. V. Shestakov), St. Petersburg: Nauka (in Russian).

Foucault M. (2008) Tekhnologii sebya [Technologies of the Self]. Logos, vol. 65, no 2, pp. 96-122 (in Russian).

Foucault M. (1998) Istoriya seksual'nosti III: Zabota o sebe [The History of Sexuality III: The Care of Self] (Transls. T. N. Titov, O. I. Khoma, ed. A. B. Mokrousov), Kiev: Dukh i litera, Grunt; Moscow: Refl-book (in Russian). 
Foucault M. (1999) Nadzirat'i nakazyvat'. Rozhdenie tyur'my [Discipline and Punish. The Birth of The Prison] (Transl. by V. Naumov), Moscow: Ad Marginem (in Russian).

Global Packaged Water Consumption to Overtake Carbonates in 2015 (2015) Available at: http://www. canadean.com/news/global-packaged-water-consumption-to-overtake-carbonates-in-2015/_ (accessed 7 March 2017).

iDrink. 2014. ITunes Preview. Available at: https://itunes.apple.com/ru/app/idrink-lucsij-treker-vody/ id953796261?mt=8 (accessed 7 March 2017).

Kahneman D., Tversky A. (1974) Judgment under Uncertainty: Heuristics and Biases. Science, vol. 185, no 4157, pp. 1124-1131.

Kak zastavit' sebya vypivat' normu vody $v$ den', 8 proverennykh sovetov (2015) [How to Force Yourself to Drink MoreWater Every Day, 8 Tested Tips]. Available at: http://svetlana-dolgih.ru/kak-pravilno-pit-vodu/ (accessed 7 March 2017) (in Russian).

Kovalyov E., Shteinberg I. (1999) Kachestvennye metody v polevykh sotsiologicheskikh issledovaniyakh [Qualitative Methods in Sociological Field Research], Moscow: Logos (in Russian).

Kovalyova A. (2008) Samosokhranitel'noe povedenie v sisteme faktorov, okazyvayushchikh vliyanie na sostoyanie zdorov'ya [Self-Protective Behaviour in a System of Health-Affected Factors]. The Journal of Sociology and Social Anthropology, vol. 11, no 2, pp. 179-191 (in Russian).

Linton J. (2010) What is Water? The History of a Modern Abstraction, Vancouver and Toronto: UBC Press.

Mishel' Foucault i Rossiya: Sb. Statei [Michel Foucault: Collected Papers] (2001) (ed. O. Kharkhordin), St. Petersburg: European University at St. Petersburg; Moscow: Summer Garden (in Russian).

Moreno J. L. (2001) Psikhodrama [Psychodrama], (transl. G. Pimochkina, E. Rachkova), Moscow: April Press; EKSMO-Press (in Russian).

My Bottle. 2015. Available at: http://mybottle-sale.ru. (accessed 4 March 2017) (in Russian).

Northcote M., McIntosh A. (1999) What Mathematics Do Adults Really Do in Everyday Life? Australian Primary Mathematics Classroom, vol. 4, no 1, pp. 19-21.

Pautov I., Pautova N. (2014) Prodvizhenie zdorovogo obraza zhizni kak instrument realizatsii gosudarstvennoj politiki v sfere okhrany zdorov'ya v sovremennoj Rossii [Promoting a Healthy Lifestyle as an Instrument of Public Health Policy in Modern Russia]. The Journal of Social Policy Studies (electronic journal), vol. 12, no 4, pp. 493-508. Available at: http://www.aup.ru/books/m245/6_3.htm (accessed 4 March 2017) (in Russian).

Ph-meter. 2017. Ismer.ru. Available at: http://ismer.ru/products/ph-metr-kl-009ii?utm_source=google\&utm_ medium $=$ cpc\&utm_term $=$ ph $\% 20 \% \mathrm{D} 0 \% \mathrm{BC} \% \mathrm{D} 0 \% \mathrm{~B} 5 \% \mathrm{D} 1 \% 82 \% \mathrm{D} 1 \% 80 \& u t m \_$campaign $=$msk_g_ph_ poisk (accessed 4 March 2017) (in Russian).

Ritzer G. (2011) Makdonal'dizatsiya obshchestva [The McDonaldization of Society] (Transl. A. Lazarev), Moscow: Praksis (in Russian). 
Roshchina Y. (2016) Stil' zhizni v otnoshenii zdorov'ya: imeet li znachenie sotsial'noe neravenstvo? [HealthRelated Lifestyle: Does Social Inequality Matter?]. Journal of Economic Sociology = Ekonomicheskaya sotsiologiya, vol. 17, no 3, pp. 13-36. Available at: https://ecsoc.hse.ru/2016-17-3.html (accessed 14 March 2017) (in Russian).

Rynok butilirovannoj vody. Tekushchaya situatsiya i prognoz 2016-2020 gg. (2016) [Bottled Water Market. Current Situation and Forecast for 2016-2020]. Alto Consulting Group. Available at: http://alto-group. ru/otchot/marketing/361-rynok-butilirovannoj-vody-tekushhaya-situaciya-i-prognoz-2014-2018-gg.html (accessed 7 March 2017) (in Russian).

Shtompka P. (2009) V fokuse vnimaniya povsednevnaya zhizn'. Novyy povorot v sotsiologii [The Focus on Everyday Life: A New Turn in Sociology]. Sociological Studies, no 8, pp. 3-13 (in Russian).

Slater D. (2008) Zabiraya rynok u ekonomistov [Capturing Markets from the Economists]. Journal of Economic Sociology = Ekonomicheskaya sotsiologiya, vol. 2, no 9, pp. 29-45. Available at: https://ecsoc.hse. ru/2008-9-2.html (accessed 19 March 2017) (in Russian).

Trentmann F., Taylor V. (2005) From Users to Consumers - Water Politics in Nineteenth Century. London: The Making of the Consumer: Knowledge, Power and Identity in the Modern World (ed. F. Trentmann), Oxford: Berg Publishers, pp. 53-79.

Valdenfels B. (1991) Povsednevnost' kak plavil'nyj tigl' ratsional'nosti [Life as a Melting Crucible Rationality]. Sotsio-Logos: sotsiologiya, antropologiya, metafizika [Socio-Logos: Sociology, Anthropology, Metaphysics]. Iss. 1. Society and Spheres of the Meaning, Moscow: Progress, pp. 39-50.

Verplanken B., Faes S. (1999) Good Intentions, Bad Habits, and Effects of Forming Implementation Intentions on Healthy Eating. European Journal of Social Psychology, vol. 29, no 5-6, pp. 591-604.

Vodnyy balans organizma (2016) [Water Balance of Organism]. kaula.ru. Available at: http://www.kaula.ru/ meropriyatiya/17-12_seminar-vodnyi-balans-organizma (accessed 7 March 2017) (in Russian).

Weber M. (1994) Izbrannoe. Obraz obshchestva [Selected Works. Sociology of Community], Moscow: Yurist (in Russian).

Weber M. (2007) Istoriya khozyaistva. Birzha i ee znachenie. [The History of Economy. The Stock Exchange and Its Meaning], Moscow: Giperboreya; Kuchkovo pole (in Russian).

Weber M. (2016) Hozyaystvo i obshchestvo: ocherki ponimayushchey sotsiologii. [Economy and Society. An Outline of Interpretive Sociology], Moscow: HSE Publishing House (in Russian).

WWAP (United Nations World Water Assessment Programme) (2015) Facing the Challenges. Case Studies and Indicators. Unesco's Contribution to the United Nations World Water Development report. Available at: http://unesdoc.unesco.org/images/0023/002321/232179E.pdf (accessed 7 March 2017).

Received: January 11, 2017.

Citation: Andreeva A., Klimeshova J., Kudryavtseva M., Lobanova A. Ratsionalizatsiya zhizni sovremennogo cheloveka na primere analiza potrebleniya vody zhitelyami Moskvy [Rationalization of Modern Life: The Case of Water Consumption in Moscow]. Journal of Economic Sociology = Ekonomicheskaya sotsiologiya, vol. 18, no 2, pp.80-111. Available at https://ecsoc.hse. ru/2017-18-2.html (in Russian). 


\section{ПРОФЕССИОНАЛЬНЫЕ ОБЗОРЫ}

\section{П. А. Попова \\ Как объяснить финансовый конфликт в семье?}

\section{Обзор экономических, психологических и социологических концепций ${ }^{1}$}

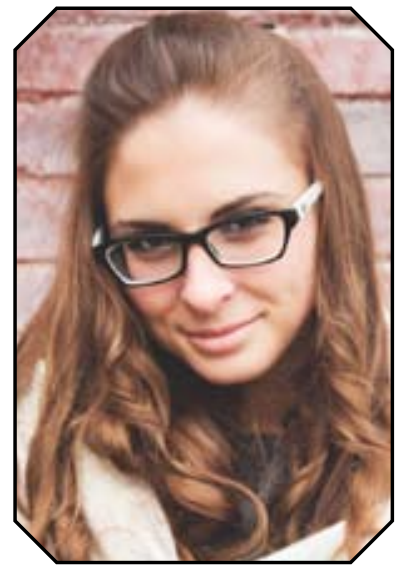

\section{ПОПОВА Полина} Артёмовна магистрант программы «Прикладные методы социального анализа рынков», преподаватель кафедры экономической социологии, менеджер Лаборатории экономикосоциологических исследований Национального исследовательского университета «Высшая школа экономики». Адрес: Россия, 101000, г. Москва, ул. Мясницкая, д. 20.

Email: papopova@hse.ru
В западной литературе финансовые конфликты выделяются как основной предиктор развода в семьях и определяются как самые сложные $и$ продолжительные для супругов. Однако вопрос о том, что является детерминантами их возникновения, обходится стороной в огромном корпусе исследований, посвящённых супружеским конфликтам или управлению финансами. Данная статья пытается ответить на вопрос о том, что же такое финансовый конфликт и как он возникает. В первой части обзора рассматриваются эмпирические исследования, посвящённые супружеским конфликтам и месту проблемы денег в их возникновении. Во второй части с помощью теорий семейных систем, семейного стресса, социального обмена, распределения благ и ролевой теории изучается процесс возникновения конфликта и выявляются предположительные предикторы, которые могут объяснить финансовый конфликт в семье. Третья часть обзора посвящена подробному рассмотрению трёх выявленных на теоретическом уровне факторов возникновения конфликта. Первым из них является управление финансами, которое представлено противопоставлением независимых стратегий и механизмов, связанных с пулом. Как следствие контроля над финансами, автор статьи показывает концепџии власти и объясняет, как основания её конструирования в домохозяйстве влияют на возникновение финансового конфликта. Ещё один изученный аспект - гендерное разделение труда, которое в соответствии с рядом исследований является ключевым фактором неудовлетворённости супругов (особенно женщин) и способствует зарождению большого количества конфликтов. В заключении делается вывод о том, что эти три аспекта взаимосвязаны и требуют эмпирической проверки в качестве предикторов для модели объяснения финансовых конфликтов в семьях.

Ключевые слова: финансовый конфликт; супружеский конфликт; управление финансами; власть в семье; гендерное разделение труда; теории функционирования семьи.

\section{Введение}

Согласно Дж. Коулману, современный мир характеризуется появлением большого количества формальных отношений, но важность близких отно-

\footnotetext{
В данной научной работе использованы результаты проекта «Экономико-социологические исследования социальной устойчивости в кризисное время», выполненного в рамках Программы фундаментальных исследований НИУ ВШЭ в 2017 г. Автор благодарит Д. Х. Ибрагимову, И. В. Павлюткина, Е. С. Бердышеву и Я. М. Рощину за полезные комментарии к тексту, а также других сотрудников Лаборатории экономико-социологических исследований, принявших участие в обсуждении концепции данной работы.
} 
шений нельзя переоценить, так как именно они влияют на развитие личности и становятся основой социального капитала человека [Coleman 1990]. Более того, интимные отношения строятся на реципрокности, взаимной поддержке и определённой доле солидарности, поэтому остаются незаменимыми для индивидов. Коррективы, которые вносит в них современный мир, заключаются в том, что формы этих отношений несколько трансформируются. Например, люди чаще сожительствуют без заключения брака, откладывают регистрацию отношений и рождение детей, а доля разводов, выросшая в 1970-х гг. и достигшая пика в 2000-2003 гг., не снижается. В России вопрос о стабильности семьи стоит достаточно остро, т.к. динамика разводов остаётся тревожной, и обращает внимание тот факт, что всё больше молодых пар распадается [Захаров 2015]. Исследователи отмечают, что ценностные ориентации на семью и детей менее заметны, на первый план выходят построение карьеры и погоня за деньгами [Pahl 1983; Гурко 2001; Здравомыслова 2003]. Рост количества разводов, по мнению некоторых российских авторов, может повлиять на нормы в обществе, то есть лёгкость расторжения брака способна создать более легкомысленное отношение к супружеству [Антонов 2012; Касаткин 2012].

Принимая во внимание вышесказанное, можно сделать вывод о нарастании в современном обществе проблем, связанных с институтом семьи. По мнению западных социологов, одним из основных предикторов развода является финансовый конфликт (см., например: [Cubbins, Vannoy 2004; Kluwer, Johnson 2007; Papp, Cummings, Goeke-Morey 2009; Dew, Britt, Huston 2012]), но по неясным причинам тема его возникновения игнорируется в научном сообществе. При этом надо отметить, что темы финансового поведения относительно недавно начали интересовать социологов; это произошло в конце 1980-х гг., когда появилась новая экономическая социология. В России интерес к этой теме возник чуть позже - в начале 2000-х гг. Основное внимание уделяется управлению финансами (см., например: [Pahl 1983; 1990; 1995; Vogler, Brockmann, Wiggins 2006; Ибрагимова 2012; 2016; Ibragimova, Guseva, 2015]) и всем его аспектам — принятию решений о покупках [Zagorsky 2003; Sun 2010], контролю над денежными ресурсами, разделению труда [Брайнс 2002; Cubbins, Vannoy 2004; Ridgeway 2011], неравенству [Вовк 2006; McLanahan, Percheski 2008; Halpern-Meekin, Turney 2016] и взаимодействию между супругами в стрессовых ситуациях [Heavey, Layne, Christensen 1993]. В последние годы возродилась и популярность темы финансовой власти [Vogler 1998; Trentham, Larwood 2001; Vogler, Lyonette, Wiggins 2008; Blossfeld, Drobnič 2009; Ибрагимова 2016]. Также можно обнаружить исследования влияния управления финансами и конфликтов по поводу денег на развод [McGonagle, Kessler, Schilling 1992; Addo, Sassler 2010; Dew, Dakin 2011; Dew, Britt, Huston 2012]. По нашему мнению, в корпусе всех этих исследований отсутствует существенное промежуточное звено - исследование того, как и откуда появляется в семьях финансовый конфликт.

Если говорить о конфликте в целом, то мы вслед за Л. Козером определяем его как форму социализации, которая предназначена для разрешения дуализмов и противоречий и способствует снятию напряжения [Козер 1956]. В. В. Танчер пишет: «Согласно аргументам Козера, конфликт может содействовать более чёткому разграничению между группами, способствовать централизации принятия решений, укреплять идеологическое единство, усиливать социальный контроль» [Танчер 1994: 269]. Однако в межличностных отношениях распространена тенденция к подавлению враждебных чувств и впоследствии к их накоплению и усилению; это происходит из-за того, что близкие люди боятся острого конфликта, - возникает замкнутый круг. Более того, выдвигается тезис о том, что чем более тесными являются социальные отношения, тем напряжённее будет конфликт; чем больше у людей общих интересов и схожих черт, тем больше они личностно вовлекаются в отношения и утрачивают способность оценивать ситуацию объективно; чем меньше группа, объединённая совместной повседневной жизнью, тем легче её участниками овладевают раздражение и гнев [Козер 1956].

Под финансовым конфликтом в данной работе мы будем понимать различные точки зрения у супругов по любой из тем, связанных с финансами, которые при наличии повода и желания (другими словами, 
конфликтной ситуации) высказываются и обсуждаются эмоционально и имеют определённый результат - например, компромисс. В качестве классификации такого рода конфликтов приведём следующую, как наиболее полно отражающую финансовое поведение семьи [Kirchler 1990]:

- вероятностный конфликт: в ситуации покупки супруги согласны в том, что касается её необходимости и ценности продукта, но не могут прийти к общему решению относительно качества альтернатив внутри категории товара;

— иенностный конфликт: разногласие по поводу этической приемлемости продукта;

- конфликт распределения: разногласие относительно распределения ресурсов между супругами в вопросе покупки.

Так как основной концепт данного исследования довольно скудно освещается в научной литературе, целью статьи является всестороннее рассмотрение финансового конфликта и определение тех аспектов жизни семьи, которые ведут к его возникновению. В первой части обзора будут показаны исследования, посвящённые супружеским конфликтам (в том числе их факторам) и выделяющие финансовые разногласия как одни из самых серьёзных; затем мы перейдём к рассмотрению теорий возникновения конфликтов в семьях; последняя часть предлагает рассмотрение следующих трёх взаимосвязанных аспектов семейной жизни, детерминирующих появление финансовых конфликтов: управление финансами, власть и гендерное разделение труда.

\section{Конфрликт в семье в фокусе исследований, посвящённых качеству брака}

Как было отмечено выше, финансовый конфликт довольно редко выступает объектом социологических исследований, однако поиск литературы, связанной с супружескими конфликтами в целом, открывает большой пласт работ, посвящённых ряду интересующих нас тем. Основными среди них являются влияние конфликтной обстановки в семье на воспитание детей, их поведение в пубертатном возрасте, психологическое здоровье и планы на будущее [Margolin, Gordis, John 2001; Berger, McLanahan 2015]. Также рассматриваются психологическое здоровье и благосостояние партнёров [Fincham 2003], a ceмейные конфликты встраиваются в исследования как составляющая индексов качества отношений (см., например: [Gottman 1994; Kluwer, Johnson 2007]). Ещё одно направление исследований - поведение супругов в конфликте, их практики разрешения разногласий и последствия, которые влечёт та или иная конфликтная стратегия (в основном такие исследования представляют психологи) (см.: [Christensen, Heavy 1990; Crohan 1996; Carrère, Gottman 1999; Driver, Gottman 2004]). К сожалению, говорить о существовании исследований, комплексно освещающих конфликт в семье, то есть его возникновение, причины, основные затрагиваемые темы, протекание, последствия и т. д., не представляется возможным [McGonagle, Kessler, Schilling 1992].

Есть много объяснений, почему супружеский конфликт стоит рассматривать отдельно, а не как показатель качества отношений или удовлетворённости ими. Так, авторы отмечают, что между этими показателями есть связь, но мы столкнёмся с затруднениями, пытаясь понять, что является причиной, а что следствием: например, супруги могут быть удовлетворены отношениями, но много конфликтовать [Lippe, Voorpostel, Hewitt 2014]. Или мы можем столкнуться с ситуацией, когда несчастные супруги склонны более открыто выражать своё недовольство по любому поводу и поднимать проблемы, в которых им хотелось бы увидеть изменения, что влияет на увеличение числа конфликтов [Kluwer, Johnson 2007]. При этом, как было отмечено выше, конфликт в семье влияет на ментальное и психологическое здоровье, он связан с рядом депрессивных симптомов (особенно у женщин) [Kandel, Davies, Raveis 1985], с расстройствами питания, алкоголизмом, способствует ухудшению социальной адаптации детей и повышает вероятность развития «конфликта отцов и детей» [Fincham 2003]. 
Так как тема конфликта укоренена в исследованиях влияния семейной среды на детей, одним из основных выводов из литературы является то, что наличие детей ведёт к повышению частоты конфликтов в семьях (см., например: [McGonagle, Kessler, Schilling 1992]), а наиболее конфликтны для супругов первые годы жизни ребёнка. Этот период исследователи называют одним из самых сложных переходов в семейном цикле и жизни родителей: к привычной для супругов диаде присоединяется ещё один член семьи, который становится центром внимания, это ведёт к снижению взаимодействия и интимности между партнёрами, повышая вероятность возникновения конфликтных ситуаций [Crohan 1996; Kluwer, Johnson 2007].

Тем не менее есть ещё один фактор, влияющий на конфликты и нивелирующий значимость наличия детей: стаж брака отрицательно связан с частотой конфликтов в семье [McGonagle, Kessler, Schilling 1992], а сожительствующие партнёры ссорятся чаще, чем оформившие свои отношения [Lippe, Voorpostel, Hewitt 2014]. Удивительная тенденция наблюдается в первых и повторных браках: несмотря на то что вероятность развода в повторных браках намного выше, чем в первых, конфликты в повторных браках случаются реже [McGonagle, Kessler, Schilling 1992].

Другие детерминанты появления семейных конфликтов можно разделить на социально-психологические и социально-экономические [Тихомирова 2010]. К первой категории причисляются базовые ценности супругов, установки (например, по отношению к распределению ролей, работе и устройству быта) и условия их социализации. Важным является то, как выстраивается взаимодействие супругов с близким окружением - родителями, родственниками и друзьями. Сюда же можно отнести ключевую причину конфликта, отмеченную Л. Козером, — неравное распределение прав [Козер 1956]. Ко второму виду факторов принадлежат статусы супругов и различия в них, материальное положение и благополучие, имущественная обеспеченность. В России одной из основных причин конфликта супруги называют вопросы, связанные с финансами [Cubbins, Vannoy 2004; Назарова 2007], поэтому перейдём теперь к более подробному их рассмотрению.

\section{Финансовый конфликт в семье и его причины: теоретические подходы}

Конфликт по поводу финансов может иметь разные стороны. Во-первых, он может быть связан с простым несогласием супругов по поводу цели использования денег, например, необходимости приобретения какой-то вещи или надёжности хранения сбережений. В таком случае это конфликт вокруг профанного значения денег. Во-вторых, это может быть конфликт, в котором основным объектом выступает ценность денег, их значение, что подразумевает их сакральность. Здесь речь идёт о конфликте ценностей: один из супругов легко расстаётся с деньгами, не считает «каждую копейку», в то время как другой - человек экономный, ему тяжело даются траты, в которых он не видит большой важности. Тем не менее эмпирические исследования показывают, что разногласия по поводу финансов в любом из проявлений отмечаются супругами как самые длительные, непримиримые и важные для дальнейших взаимоотношений. Более того, если конфликт связан с глубинными ценностями, касающимися денег, супруги чаще использовали «негативные» тактики в конфликте, то есть отказывались идти на компромисс, повышали голос и оскорбляли друг друга [Dew, Britt, Huston 2012]. При этом важно отметить, что исследователи не связывают финансовые конфликты с финансовыми затруднениями, объясняя это тем, что супруги объединяются для решения общей проблемы и стараются сводить на нет любые разногласия, возникающие на эту тему [Dew, Dakin 2011]. Иными словами, мы можем предположить, учитывая природу конфликта, что при наличии финансовых проблем вопросы присвоения власти или неравенства между супругами уходят на второй план, у супругов просто не остаётся ресурсов, в борьбе за которые они выстраивают конфликт.

Для рассмотрения финансового конфликта стоит обратиться к двум типам теорий: к теориям возникновения конфликта и теориям, посвящённым функционированию семьи. 
Теория семейных систем считает, что индивиды взаимодействуют друг с другом через различные взаимосвязанные системы (такие социальные институты, как семья, работа), внутри которых определяются результаты этого взаимодействия. Супруги между собой могут часто конфликтовать, но если для них первостепенна борьба за здоровье отношений, то эта теория определит данных супругов как борющихся за позитивный исход любых конфликтов. При этом теория не рассматривает, что именно является источником разногласия; во главу угла ставится то, как супруги эти разногласия преодолевают. Однако Дж. Дью и его соавторы [Dew, Britt, Huston 2012] обнаружили, что в тех семьях, где финансовые разногласия отмечаются как одни из самых важных и частых, имеется гораздо больше негативных взаимодействий (жарких споров, острых конфликтов) по сравнению с теми, кто отметил в качестве важнейших разногласия по поводу воспитания детей [Dew, Britt, Huston 2012].

Теория семейного стресса (см.: [Conger et al. 1994]) утверждает, что наличие экономического давления на семью, связанного с нестабильностью финансовых ресурсов, создаёт большое количество стрессовых ситуаций и повышает конфликтную обстановку в семье. Однако даже в случаях, когда у супругов есть достаточный объём ресурсов для удовлетворения общих потребностей, тема денег не исчезает из конфликтных тематик в связи с тем, что деньги всегда ограничены в какой-то степени, а потребности и желания членов семьи по отношению к трате денег могут превышать существующие возможности. Более того, независимо от объёма бюджета некоторые члены семьи могут чувствовать себя депривированными из-за распределения доступа к имеющимся ресурсам, возможностей их тратить или их воспринимаемых или реальных различий. Воспринимаемая членами семьи социальная власть и осознание собственной ценности могут быть значимы под влиянием их понимания вовлечённости в принятие решений о деньгах, которые, в свою очередь, могут быть связаны с финансовыми разногласиями [Papp, Cummings, Goeke-Morey 2009].

Теория распределения благ является экономически окрашенной и возвращает нас к проблеме власти. Её авторы говорят о том, что всё строится вокруг власти и контроля. Однако этот последний является сейчас явно гендерно окрашенным ресурсом, поэтому редко можно встретить семьи, в которых финансовое взаимодействие приносит значимую выгоду и мужчине, и женщине. Так, методом кейс-стади было установлено, что финансовые затруднения могут вызывать проблемы власти или контроля, в том числе чувство зависимости при обсуждении финансовых решений и даже прямую враждебность из-за того, что у одного из супругов больше финансового контроля [Jenkins et al. 2002; Shapiro 2007].

Ролевые теории также обращают внимание на власть и утверждают, что люди с её большим объёмом имеют больше не только привилегий и прав, но и обязанностей. Лидеры несут безусловную ответственность за определение группового решения; в таких ситуациях они оказываются вынуждены решать любые конфликты, которые могут быть следствием связанных с этими ситуациями проблем (например, необходимость определения того, на что именно потратить сбережения и какие категории товаров и услуг являются приоритетными для домохозяйства).

Теория конфликта отмечает, что у партнёров есть различное количество власти и ресурсов в отношениях с соответственно различным количеством собственных интересов, которые следует поддерживать. Когда появляются разногласия, которые связаны с различиями властного статуса партнёров, ожидается, что более властный партнёр победит в споре, а менее властный поддастся другому. Также можно предположить, что менее властный партнёр окажется виноватым в провоцировании конфликта, потому что не в его «полномочиях» конфликтовать с тем, у кого этой власти больше [Trentham., Larwood 2001].

Теория социального обмена считает, что целью брака является максимизация выгод и минимизирование издержек, связанных с отношениями. Удовлетворённость браком оказывается высокой в том случае, 
когда результаты отношений превышают или просто приравниваются к ожиданиям индивида. Если же результаты оказываются неудовлетворительными, издержки начинают казаться высокими. Более того, нельзя игнорировать тот факт, что, помимо структуры самих отношений, экономические теории подчёркивают и наличие альтернатив вне брака, то есть осознание того, что вне брака или в браке с другим партнёром результаты повысятся, индивид решается на конфликты, и, как следствие, происходит расторжение брака [Huinink 2009].

В дополнение к перечисленным теориям нельзя не отметить, что некоторые авторы (см., например: [Dew, Britt, Huston 2012; Alsemgeest 2014]) называют тему денег в современном обществе одним из последних табу в ведении беседы. Социологам известно, что доля отказов от ответа в вопросах о личных доходах иногда бывает просто зашкаливающей, что приводит к применению различных методик для восстановления данных. Тем не менее отказ раскрывать данные о своих деньгах незнакомому человеку ещё можно понять, но из исследований видно, что эта тема является сензитивной и в кругах близкого, интимного общения. Люди чувствуют смущение, касаясь этой темы, она вызывает эмоциональное напряжение, из-за чего её предпочитают избегать. По мнению Р. Белка и М. Волендорфа, деньги являются уникальным предметом, так как могут быть определены и как профанное (они используются в повседневной жизни и являются чем-то обыденным), и как сакральное (из-за тех смыслов и ценностей, которые в них вкладываются) [Belk, Wallendorf 1990]. Так, в одном из исследований показано, что родители, скорее, предпочтут обсудить с детьми тему наркотиков или секса, чем будут делиться механизмом финансовых потоков внутри семьи [Alsemgeest 2014]. Это приводит к тому, что родители не являются (хотя должны бы) проводниками в мир финансового управления для детей, которым приходится всё постигать самостоятельно, а культура замалчивания передаётся от поколения к поколению.

Есть и другие объяснения этому феномену, помимо смущения и эмоционального напряжения. Деньги связываются с концептами власти, которая, в свою очередь, укоренена в одной из самых актуальных тем сегодняшнего времени - проблеме (не)равенства. Такая тесная связь приводит к тому, что тема денег обязательно должна вести к конфликту, ведь его рождает противоборство вокруг ресурсов. Власть можно считать одним из важнейших ресурсов, а деньги - его самый простой и повсеместно распространённый индикатор; при этом сами они также являются ресурсом. Получается, что деньги могут быть как индикатором, отражающим неравенство, так и механизмом, поддерживающим это неравенство [Pahl 1983]. Следовательно, чтобы избежать конфликта, о деньгах стараются не говорить. Причём понятно, что деньги - показатель власти не только в обществе, но и в семье. Интересно отметить, говоря о модели в целом, что традиционно всё выглядит следующим образом: когда муж зарабатывает больше жены и выполняет роль основного кормильца семьи, она обязана взять на себя больше домашних дел. Если же жена зарабатывает больше мужа, то зачастую распределение обязанностей, скорее, склоняется к равноправию, чем к ситуации, когда женщина в основном исполняет роль кормильца, а мужчина занят по дому [Alsemgeest 2014]. Эта модель ещё раз доказывает, что тема денег и власти, а также вытекающего из них конфликта имеет основания для исследования, так как при принятии модели, которая предполагает реверсивность ролей мужчины и женщины, мужская традиционная роль ставится под сомнение, вызывая внутреннюю напряжённость, повышая неудовлетворённость и увеличивая количество поводов для разногласий.

Являясь латентной характеристикой, власть во всех исследовательских работах об управлении финансами в семье имеет своё толкование и концептуализацию. Однако не все авторы стремятся рассмотреть непосредственно власть в семье и ограничиваются более простыми вопросами финансового поведения. Например, в одном из исследований обнаружилось, что модель финансового управления оказывает существенное влияние на такой показатель качества отношений, как частота конфликтов и их напряжённость [Addo, Sassler 2010]. Есть также авторы, которые говорят о том, что деньги в семье однозначно связаны с такими скрытыми характеристиками, как власть и контроль, потому что на- 
личие ощущения несправедливости хотя бы у одного из супругов является предиктором финансовых разногласий [Dew, Britt, Huston 2012]. Более того, нельзя не согласиться с тем, что финансовые проблемы в семьях можно назвать в какой-то мере особенными, так как этот аспект жизни супруги почти не могут игнорировать. Они сталкиваются с деньгами, решениями о покупках и другими видами финансового поведения каждый день, поэтому просто замолчать или обойти такие проблемы представляется сложной задачей [Dew, Dakin 2011]. В. Зелизер пишет: «Хотя именно деньги служат основным источником разногласий между мужем и женой, больной мозолью в отношениях между родителями и детьми, о семейных денежных делах нам известно меньше, чем о насилии в семье или даже о сексе» [Зелизер 2002: 64].

Не удивительно, что результаты многих исследований (см., например: [Amato, Rogers 1997; Dew 2009; 2011; Britt, Huston 2012; Dew, Britt, Huston 2012]) показывают, что финансовые разногласия являются одним из основных предикторов разводов: в исследовании Дж. Дью, С. Бритт и С. Хьюстон конфликты по поводу финансов стоят на первом месте как для мужчин, так и для женщин, на втором месте для мужчин располагаются конфликты по поводу сексуальных отношений, а для женщин — конфликты по вопросам воспитания детей.

Ещё одно важное замечание по поводу причин финансового конфликта связано с эмпирическим исследованием Л. Куббинс и Д. Ванной, проведённым в Москве. Авторы утверждают, что экономические ресурсы супругов, их гендерные установки и ограничения во времени влияют на семейные раздоры и стабильность как напрямую, так и через распределение домашних обязанностей [Cubbins, Vannoy 2004].

Именно из этих теорий мы можем сделать вывод, что в качестве основных факторов возникновения финансовых конфликтов нам следует подробнее остановиться на вопросах управления финансами, власти и гендерного дисплея супругов.

\section{Теоретические детерминанты финансовых конфликтов в семьях}

\section{Управление фринансами в семьях как поле для возникновения разногласий}

Исследования механизмов управления финансами с 1980-х гг. стали относительно популярны в социологии (см.: [Pahl 1983; 1990; 1995; Kirchler 1993; 1995; Vogler, Pahl 1993; 1994; Vogler 1998; 2005; Clarke 2002; Vogler, Brockmann, Wiggins 2006; Burgoyne et al. 2007; Vogler, Lyonette, Wiggins 2008]. В данном обзоре мы не будем подробно анализировать все результаты этих работ, но постараемся выделить основные понятия и тренды, которые нам необходимы.

Своего рода канон для изучения финансового управления в семьях задали британские учёные Ж. Пал и К. Воглер, создавшие классификацию механизмов управления финансами, а также выдвинувшие две общие теории появления в семьях той или иной системы распоряжения деньгами - ресурсную и гендерную [Pahl 1983; 1990; Vogler 1998]. Указанные авторы с помощью серии своих исследований показали и то, что для получения самых интересных и надёжных результатов требуется опрашивать обоих супругов, причём раздельно, чтобы у них не было возможности согласовать ответы. Результаты таких действий доказывают, что, вопреки экономическим воззрениям, нельзя семью рассматривать как гомогенный союз и приписывать ему одну модель поведения и одно решение [Ferber, Lee 1974]. Однако исследования во многих странах, в том числе и в России (первопроходцем в этой области стал C. Кларк [Clarke 2002]), говорят о том, что семьи в основном придерживаются системы общего пула и большинство решений принимают сообща. 
Механизм управления финансами несколько разнится в зависимости от стажа брака и, по мнению К. Бургойн, от того, проживали супруги вместе до свадьбы или нет. До момента обоюдного осознания того, что отношения перешли в формат брака, доминирующим типом управления является независимое (65\%). После одного года, проведённого в браке, ситуация меняется: большинство пар, которые до свадьбы придерживались системы независимого распределения финансов, перешли к системе общего или частичного пула. Автор объясняет это общественными нормами, которые предполагают, что семья строится на реципрокности, то есть супруги делятся друг с другом [Burgoyne et. al. 2007: 222-227]. Однако этому утверждению можно противопоставить позицию А. Уайтхед, приведённую Ж. Пал (см.: [Pahl 1983: 254-255]). Согласно этой позиции, независимо от формы материального конфликта между мужчиной и женщиной одно его наличие доказывает: семья - это союз, который основан не исключительно на реципрокных интересах.

Перейдём к рассмотрению теорий, раскрывающих механизм управления финансами. Коллективный подход говорит о том, что супруги, сосредоточенные на общих целях, создают и общий счёт, потому что коллективные стратегии обычно более выгодны, чем индивидуальные подходы к финансовому управлению. Эффективность коллективных стратегий связана с тем, что они снижают издержки обмена между партнёрами и максимизируют собственные интересы, потому что стабилизируют и усиливают семью. Общий пул может также сигнализировать о большой привязанности к семье и вкладе в её будущее, усиливая связи доминированием общих интересов над личными. Те, кто настаивает на своей личной автономии в вопросах финансов, даже состоя в отношениях, показывают приверженность собственным интересам над коллективными целями. Так, К. Кенни обнаружила, что те супруги, которые описывали своего партнёра как заботливого, поддерживающего и понимающего, были более склонны создавать общие стратегии управления деньгами (общий или частичный пул) по сравнению с теми, которые не описывали так характер своего супруга [Kenney 2006]. Есть также подходы, утверждающие, что автономное управление финансами говорит о попытке повысить равенство партнёров в отношениях, однако разделение счетов, наоборот, может вести к неравенству ввиду гендерных различий в уровне заработка и домашних обязанностей [Addo, Sassler 2010].

Также для дальнейшего исследования важно отразить разделение управления финансами на три составляющие, которые обнаружила Ж. Пал [Pahl 1983]:

- контроль относится к вопросу того, какая система управления ресурсами должна быть в домохозяйстве, кто из супругов должен иметь последнее слово при принятии важных финансовых решений и насколько у супругов есть собственные деньги или доступ к общим деньгам;

- менеджмент - это оперирование какой-либо системой управления деньгами в разрезе того, на какие из сфер жизни их тратить;

— бюджетирование —это распоряжение деньгами внутри категорий трат.

Здесь хотелось бы вернуться к классификации конфликтов, которая была представлена во введении, и отметить, что классификации Э. Кирхлера и Ж. Пал взаимосвязаны. Вероятностный конфликт относится к бюджетированию, конфликт распределения соотносится с контролем в семье, а ценностный может быть связан с вопросами менеджмента, так как супруги имеют разное представление о том, на какие категории товаров и услуг тратить деньги. Например, если у жены выражена ценность безопасности, ощущения финансовой защищённости, она может высказывать желание сберегать большую часть денег; у супруга же при этом могут быть другие ценности - например, он хочет иметь высокий статус, для создания которого ему нужно вкладывать деньги в дорогие автомобили, недвижимость, дорогой ремонт, путешествия. Понятно, что партнёры зачастую не имеют одинаковых желаний отно- 
сительно совершения покупок. Если открытый или скрытый конфликт проявляется, супруги должны решить его, достигая собственных целей и учитывая желания и потребности партнёра [Kirchler 1990].

Итак, мы обнаружили, что финансовое управление в семье может являться индикатором власти, а распределение власти, в свою очередь, способно становиться объектом для конфликта. Теперь перейдём к подробному рассмотрению властных отношений внутри семьи.

\section{Власть в семье как ресурс, вокруг которого возникает фринансовый конфрликт}

Почему рассмотрение власти в семье так актуально для данной темы? Во-первых, определив понятие «конфликт», мы уже поняли, что власть может быть тем существенным ресурсом, вокруг которого происходят столкновения внутри семьи, а деньги - отличный индикатор этого ресурса. Во-вторых, до начала XX века модель семьи была в основном традиционной и мало различалась от семьи к семье: мужчина зарабатывал деньги, был кормильцем, а женщина вела домашнее хозяйство и воспитывала детей. С появлением у женщины экономических прав, с её активным вовлечением в рынок труда должен был произойти и существенный сдвиг в семейной сфере. Основное беспокойство сторонников экономической теории семьи заключалось в том, что изменения в потенциальном доходе женщин поставят под угрозу взаимозависимость полов, которая производилась с помощью гендерного разделения труда в семье и на рынке, и дестабилизируют семью как социальный институт [Blossfeld, Drobnič 2009]. Однако исследователи начали замечать интересные тенденции.

В исследовании 2004 г. Л. Куббинс и Д. Ванной рассуждают о том, что на примере российского общества можно хорошо показать тенденции, которые происходят в институте семьи. По их оценкам, на тот период 92\% женщин были заняты на рынке труда, но при этом в среднем женщина работала на один месяц больше, чем её муж, если принять во внимание работу по дому. Такая ситуация может приводить к тому, что женщина оказывается неудовлетворённой своим положением, поэтому авторы делают вывод, что на семейные раздоры и стабильность влияют гендерные идеологии, экономические ресурсы и временные ресурсы каждого из супругов, причём это влияние может быть как прямым, так и опосредованным домашним распределением обязанностей [Cubbins, Vannoy 2004].

Таким образом, можно предположить, что современная женщина зарабатывает, имеет определённый доход и гораздо больше мужчины делает по дому, но больше ли у неё финансовой власти? Ответ может быть отрицательным, так как, по мнению некоторых авторов, семья и власть в ней - главные источники репродукции неравенства [Pahl 1983; McLanahan, Percheski 2008; Addo, Sassler 2010; Ибрагимова 2016]. Неравенство в доходах мужчин и женщин обнаруживается наравне с разным отношением к доходу; женский доход зачастую воспринимается как «деньги на булавки», то есть на какие-то мелочи, которые женщина может сама себе позволить, не вовлекая в это ресурсы мужа [Зелизер 2002]. Изменения же в структуре современной семьи способствуют воспроизводству неравенства двумя способами [McLanahan, Percheski 2008]:

- родительство влияет на занятость и заработок женщин намного сильнее, чем мужчин, потому что именно женщины несут основную ответственность за воспитание ребёнка. Это накладывается на то, что до рождения ребёнка женщины итак зарабатывают меньше мужчин, а после декрета разрыв в их доходах может быть уже непреодолим;

- мать, в случае если остаётся одна, обычно несёт несоизмеримую финансовую и временную нагрузку по сравнению с бывшим партнёром. 
При этом, несмотря на растущее число женщин на рынке труда, мужчины по-прежнему, более вероятно, принимают на себя роль партнёра с большим количеством властных ресурсов [Dew, Dakin 2011]. По мнению А. Комтер, мощный недостаток гендерного равенства возникает из норм о гендере, концепций маскулинности и феминности и невыраженных словами правил взаимодействий между мужчинами и женщинами [Komter 1989]. Вопрос гендерных установок очень важен, но он заслуживает отдельного подробного рассмотрения.

Теперь необходимо понять, как властные процессы могут выражаться в семьях и что является их индикаторами. Власть в семье обычно возникает тогда, когда один из супругов или оба не видят возможностей для изменений в своих отношениях, а все происходящее воспринимается ими как естественное, поскольку желания подвластного супруга формируются идеологией. Желание изменений - это, конечно, субъективная характеристика, которая может быть определена в сослагательном наклонении: что сделал бы (или не сделал бы) супруг в отсутствие власти второго супруга? Комтер выделяет пять структурных элементов, связанных с любым изменением [Komter 1989]:

- желания или попытки что-то изменить;

- структурные и психологические препятствия;

— реакция партнёра на изменения;

— конфликты, которые могут возникнуть в процессе изменений;

- стратегии осуществления или предотвращения изменений.

Можно предположить, что в случае наличия открытой власти осуществление изменений будет находиться в руках властного партнёра, и именно он будет принимать решения о том, стоит ли что-либо менять. В случае скрытой власти для супругов важны пункты 4 и 5 , а также реакция партнёра. Латентная власть может вовлекать все пять аспектов. Эмпирическое исследование А. Комтер показало, что конфликты в семьях появляются тогда, когда попытка что-либо изменить провалилась: супруги не согласились друг с другом о содержании изменений или о скорости их осуществления [Komter 1989].

Среди основных индикаторов власти - принятие решений, но это одномерное рассмотрение власти. В двумерном её рассмотрении конфликт может пониматься как результат невидимых и нерешённых проблем, поэтому присвоение власти предполагает и присвоение ответственности за последствия, которые станут результатом принятия того или иного решения. Вслед за Д. Х. Ибрагимовой мы будем определять финансовую власть как «не только способность субъекта оказывать влияние (подчинять) на поведение и (или) установки и ценности объекта, осуществляя в том числе контроль над значимыми расходами, но и способность объекта “уходить” от контроля и сохранять некоторую независимость (автономию). Финансовую власть в этом смысле корректнее определять как квазисимметричные отношения» [Ибрагимова 2016: 121].

Всему сказанному выше соответствует теория К. Сафилос-Ротшильд, разделявшей финансовую власть на руководящую и исполнительную. Тот супруг, у которого констатируется руководящая власть, имеет власть над важными и нечастыми решениями, определяющими уровень и стиль жизни, важные характеристики семьи. Этот супруг может делегировать неважные и требующие времени решения другому. Этот другой в таком случае имеет исполнительную власть, ограниченную ключевыми решениями, которые делает более властный партнёр. Конфликт появляется тогда, когда исполняющий супруг пытается изменить или переопределить ситуационный контекст, стоящий за границами, установленными руководящим супругом [Pahl 1983].

Стоит отметить, что мы намеренно не рассматриваем в данной работе строго экономические теории принятия решений (например, теорию рационального выбора), так как экономисты-бихевиористы, эко- 
номические психологи и экономические социологи однозначно сходятся во мнении, что экономические решения в целом и потребительские решения в особенности не вписываются в модели рационального выбора [Kirchler, Hoelzl 2011]. Тип решения обычно находится под влиянием ряда факторов - например, характеристик продукта и его символического значения, социальной значимости. Также нельзя не рассматривать ещё один аспект: повлияет ли принятое финансовое решение на других членов домохозяйства и в какой степени [Kirchler et al. 2001]?

Более того, теории экономического и социального обмена не могут охватить всей сложности взаимоотношений между мужчинами и женщинами в браке, так как в ситуации, когда в центр взаимодействия поставлена категория гендера, возникает иной тип обмена, а проявления феминности и маскулинности рутинизируются [Брайнс 2002]. Брак поэтому создаёт пространство для реализации статусных притязаний, особенно относящихся к «самому глубокому ощущению того, чем является человек, гендерной идентичности» [Goffman 1977: 315]. Есть авторы, которые намеренно строят свои теории власти и принятия решений вокруг гендерных характеристик супругов. Власть приравнивается к так называемому последнему слову в принятии решений и операционализируется через него. Если говорить о крупных покупках, то в традиционном типе семьи обычно женщины отвечают за приобретение товаров для семьи и детей, принимают решения, касающиеся товаров для интерьера и для кухни. Также они довольно часто отвечают за стиль или цвет, если речь идёт о мебели, автомобиле. Остальные решения являются мужскими и высоко ценятся, в отличие от решений, относящихся к понятию «женское дело», которые автоматически становятся тривиальными [Sun 2010: 7]. Мужчины отвечают за приобретение технического оборудования, автомобиля, недвижимости, а также за общий объём расходов, определение торговой марки, цену, место, время и тип покупки. Интересно, что в прикладных исследованиях отмечается, что ситуация не меняется с переходом от традиционного типа семьи к более современному и область принятия решений и ответственность каждого из супругов остались теми же [Попова, Синявская 2011: 136].

Чтобы разобраться, почему никакой трансформации властных отношений не происходит, рассмотрим важные для социологии гендерные теории, которые помогут нам понять, почему ответственность в принятии решений сохраняет свои традиционные окраски.

\section{Гендерный дисплей и распределение домашних обязанностей как предиктор конфрликтов и пространство реализации властных отношений}

Гендер важен для анализа механизмов, происходящих внутри семьи, так как партнёры изначально занимают определённые роли, отношения имеют гендерную нагрузку. Более того, мужчины и женщины по-разному социализируются, в связи с чем их поведение и уклад не могут быть обоснованы исключительно ресурсными характеристиками. По мнению некоторых зарубежных авторов (см., например: [Kluwer, Heesink, Van de Vliert 1996]), установки супругов - особенно жены - относительно распределения домашнего труда в семье являются важным предиктором конфликтов. Это связывается с тем, что позиция женщин обычно является более депривированной и они более склонны к высказыванию своего недовольства по сравнению с мужчинами. Указывается, что Г. Беккер утверждал: снижение специализации гендерных ролей в браке (то есть выход женщины на рынок труда или забота мужчин о домашнем хозяйстве) ведет к умалению ценности брака, а значит, к его откладыванию или вообще к отсутствию (см.: [Booth, Crouter, Clements 2001: 297]. По названным причинам мы не можем не рассмотреть этот важный аспект в работе, посвящённой детерминантам финансовых разногласий.

Одно из ключевых исследований на тему домашних обязанностей и их распределения принадлежит Д. Брайнс, которая отмечает, что, несмотря на произошедшую на рынке труда революцию (массовый выход замужних женщин на работу), существенного перераспределения дел внутри семьи не проис- 
ходит: «Занятость жены вне дома очень слабо влияет на увеличение времени, затрачиваемого мужем на работу по дому (на 1-2 часа в неделю)» [Брайнс 2002: 346]. При этом складывающаяся гендерная нагрузка иногда служит компенсаторным механизмом, выравнивая соотношение партнёров на рынке труда распределением домашних обязанностей. Так, например, мужчина в современном обществе может зарабатывать меньше женщины, но, чтобы не ломать его представление о себе как о мужчине, женщина делегирует ему больше власти в домохозяйстве, не нагружая его большим количеством домашней работы, а беря её на себя [Брайнс 2002; Ибрагимова 2016]. Как выяснила Т. М. Дадаева, когда жена зарабатывает значительно больше мужа, распределения в сторону эгалитарного типа не происходит [Дадаева 2005]. Более того, в большинстве таких семей (60\%) именно жены чаще всего выполняют домашние обязанности. Получается, что в этом случае жене приходится быть кормильцем и заниматься домашними делами [Дадаева 2005]. Тем не менее может происходить и обратное: муж, зарабатывающий меньше, активнее вовлекается в бытовую жизнь семьи и воспитание детей [Deutsch, Roksa, Meeske 2003], что коррелирует с происходящим в обществе «кризисом маскулинности», то есть ослаблением структурированности гендерных ролей. В целом же гендерное разделение в домохозяйстве играет центральную роль в конструировании гендерного неравенства: напрямую это происходит через распределение обязанностей, а косвенно - через участие в рынке труда. При этом появляющееся неравенство поддерживается культурными установками и распределением материальных ресурсов [Ridgeway 2011].

Некоторые исследователи-психологи считают, что в процессе социализации мужчин приучают к независимости и индивидуальности, а женщин, наоборот, к зависимости от взаимоотношений. В связи с этим возникают разные страхи: мужчины боятся привязанности, а женщины переживают из-за отчуждения и потери отношений. Кроме того, физиологически женщины устойчивее к стрессам, поэтому чаще конфликтуют и применяют в этом случае более негативные тактики, в то время как мужчины предпочитают от ссор уходить. При этом мужчины видятся консерваторами в близких отношениях, a женщины выступают агентами изменений [Christensen, Heavey 1990]. Суммируя перечисленные психологические особенности и то, что нами уже было сказано о финансовой власти в семьях, можно констатировать определённую предзаданность: в обществе существуют чёткие представления о феминности и маскулинности, внутри которых супруги примеряют на себя какие-то роли (они, в свою очередь, ситуативны), поэтому, в основном, мужчины выступают в качестве более властных партнёров, а женщины - в роли тех, кто либо подчиняется, либо настаивает на изменениях.

В России большинство семей пока остаются патриархальными [Cubbins, Vannoy 2004]. Патриархат определяют как систему социальных структур и практик, в которых обнаруживаются доминирование мужчины над женщиной и её эксплуатация. Однако такая трактовка этого концепта кажется некоторым авторам противоречивой и изжившей себя при рассмотрении современного общества [Blossfeld, Drobnič 2009]. Тем не менее нельзя спорить с тем, что такое распределение ролей, как мужчина кормилец семьи и женщина - хранительница очага, считается в обществе одним из самых «нормальных», а обратная ситуация может вызвать социальное осуждение. Более того, противоположное традиционному распределение может угрожать и идентичностям партнёров, ведь конструирование гендера предполагает каждодневное доказательство - себе и окружающим - принадлежности к одному из полов [Брайнс 2002]. Самый простой вариант для женщины доказать себе, что она - женщина, стать матерью и вести хозяйство; мужчина же самоидентифицируется через возможность обеспечить и защитить свою семью.

Что касается управления финансами, то зачастую именно женщина является более осведомлённой о финансовом состоянии семьи и именно она тратит бо́льшую часть денег. Как утверждает Т. С. Лыткина, женщина в основном отвечает за покупку продуктов, товаров для дома и детей [Лыткина 2004: 86-87]. Исследование Т. М. Дадаевой показало, что полностью не удовлетворены разделением обязан- 
ностей по дому 10,9\% женщин и 1,8\% мужчин; ещё 43,5\% женщин и 27,8\% мужчин удовлетворены частично. Полностью удовлетворены сложившимся распределением домашних дел 70,4\% мужчин, среди женщин таких 45,6\%. Причины (не)удовлетворённости женщин, по мнению исследователей, могут быть объяснены, с одной стороны, проявлением традиционной культуры, а с другой - экономическими обстоятельствами [Дадаева 2005]. Важно отметить, что каждодневное взаимодействие с деньгами, планирование повседневных покупок говорит, скорее, ещё об одной домашней обязанности, в то время как контроль над деньгами и принятие ключевых решений свидетельствуют о власти в семье.

Мужчины и женщины различаются не только механизмами социализации, но и восприятием. Что касается финансового поведения, при раздельном опросе супругов выявляется очень разное восприятие благосостояния семьи; согласие в оценках можно чаще обнаружить в вопросах о доходах, но не об активах и общем благополучии. Так, мужчины склонны отмечать более высокий доход и более высокие активы семьи, подчёркивая наличие автомобиля или предметов роскоши. Женщины же гораздо чаще отмечают наличие у семьи долгов, занижая благосостояние [Zagorsky 2003].

Для нашего исследования интересно также то, что женщины имеют меньшую склонность к риску, выбирая более надёжные стратегии для хранения сбережений или менее рисковые инвестиции. Женщинам оказывается гораздо проще управлять финансами на ежедневной основе, принимая решения о рутинных покупках и необходимых для семьи вещах. Решения же о крупных инвестициях они предпочитают принимать совместно с мужчиной, хотя мужчины демонстрируют высокую готовность принимать такие решения самостоятельно. Авторы объясняют это более высокой уверенностью мужчин в собственной финансовой компетентности, однако существует опасность переоценки мужчинами собственных возможностей [Hira, Loibl 2008].

Таким образом, мы делаем вывод, что гендерное разделение в семьях может способствовать усилению неравенства и провоцировать в семье ситуации неудовлетворённости и борьбы за власть, которая, в свою очередь, чревата конфликтами. К конфликтам также может привести и различное восприятие супругов благосостояния и активов семьи: если муж будет считать, что в семье всё отлично, и настаивать на крупной покупке, а женщина - переоценивать долги и недооценивать благополучие, может возникнуть спорная ситуация, в которой проявятся и властные механизмы внутри семьи.

\section{Заключение}

Конфликт - неотъемлемая часть любых социальных отношений, но именно в близких отношениях он имеет яркие проявления и различные функции - как интегрирующие, так и разрушительные. Наиболее важным примером разрушительного для семейных отношений конфликта оказывается, по мнению авторов, финансовый (см.: [Dew, Dakin 2011; Dew, Britt, Huston 2012]), так как тема денег в современном мире является одной из самых сензитивных, и она подразумевает многие смыслы: во-первых, финансы служат как индикатором власти, так и ресурсом, вокруг которого конструируется власть; вовторых, деньги поддерживают гендерное неравенство [Pahl 1983]. Именно финансовый конфликт в ряде исследований отмечается как самый частый [Тихомирова 2010], а также самый «неприятный» для супругов, поскольку ему присущи наибольшая продолжительность и острота.

Рассмотрев различные теории возникновения конфликта и функционирования семейных отношений, мы можем сделать вывод, что финансовый конфликт в основном скрывает проблемы власти и контроля, а также гендерного разделения труда (соотношения вовлечённости супругов в рынок труда и домашнюю работу); следовательно, изучение оснований возникновения конфликта может дать нам ключ к его объяснению. Но изучение литературы показывает, что авторы в своих исследованиях не сосредоточиваются на вопросе возникновения финансовых конфликтов; гораздо чаще они исследу- 
ют его последствия, главным из которых является развод (см.: [Amato, Rogers 1997; Dew 2009; 2011; Dew, Dakin 2011; Dew, Britt, Huston 2012]), или фокусируются на удовлетворённости отношениями [Crohan 1996; Kluwer, Johnson 2007]. Более того, абсолютное большинство работ на эту тему было проведено в США, небольшая часть в Европе, на Россию же приходится одно исследование финансовых конфликтов [Cubbins, Vannoy 2004] и небольшая доля исследований об управлении финансами и властных отношениях [Komter 1989; Clarke 2002; Ибрагимова 2012; 2016].

Напрямую с возникновением финансовых разногласий может быть связано управление финансами: в парах с независимым управлением разногласия возникают чаще, так как общий пул говорит о большей привязанности к семье, о намерении выстраивать общее будущее и о совместном принятии многих решений. Проявляется эта закономерность в том, что в сожительствах (а в этом случае гораздо чаще, чем в зарегистрированных союзах, партнёры придерживаются независимого управления) частота конфликтов по поводу денег выше [Lippe, Voorpostel, Hewitt 2014]. Более того, управление финансами может меняться с течением времени и в зависимости от жизненного цикла семьи, на него способны повлиять рождение ребёнка, с которым также связывают увеличение числа конфликтов, потеря работы одним из супругов, финансовые трудности и т. д.

Распределение власти в семье является ещё одним полем для возникновения финансовых конфликтов, так как идеология (традиционные представления о ролях в семье) может противоречить ресурсным характеристикам супругов (равное участие на рынке труда или ситуации, когда фактическим кормильцем семьи выступает женщина). Вопрос властных отношений может вести к финансовым конфликтам и в связи с тем, что мужчины и женщины по-разному воспринимают благосостояние семьи (мужчины отмечают наличие статусных вещей, а женщины - отсутствие долгов) [Zagorsky 2003] и по-разному распределяют свои ресурсы (женщины гораздо чаще совершают покупки для дома и детей).

Тесно пересекается с управлением финансами и вопросом власти гендерное разделение труда в семье. В современном мире гендерная специализация снижается, но в домохозяйствах распределение труда пока традиционно. В связи с этим оказывается, что женщины работают гораздо больше мужчин (если учитывать как рынок труда, так и выполнение домашних обязанностей) [Cubbins, Vannoy 2004]. При этом опросы показывают, что мужчины гораздо чаще удовлетворены своим участием в домашних делах, чем женщины [Дадаева 2005], а неудовлетворённость этим аспектом отношений у женщин повышает вероятность развода.

Таким образом, изучив корпус литературы, посвящённой супружеским конфликтам и финансовому поведению семьи, мы можем на теоретическом уровне предполагать, что именно механизмы управления финансами, властные отношения и гендерное разделение труда способны объяснять возникновение и частоту финансовых разногласий в семьях. Учитывая изменения в институте семьи и не снижающееся число разводов, мы считаем важным заострить внимание на проблеме финансовых конфликтов, так как их роль в семейной жизни не должна быть упущена из виду. Дальнейшим развитием данной темы должно стать проведение обширного эмпирического исследования, которое сможет подтвердить или опровергнуть значимость указанных аспектов для возникновения финансовых конфликтов в семье, а также определить, какие группы населения особенно подвержены возникновению этого феномена.

\section{Литература}

Антонов А.И. 2012. Катастрофические изменения института семьи и крайняя настоятельность просемейной политики. URL: http:/www.ssa-rss.ru/files/File/congress2012/part21.pdf 
Брайнс Дж. 2002. Экономическая зависимость, гендер и домашнее разделение труда. В сб.: Мезенцева Е. Б. (сост., отв. ред.) Гендер и экономика: мировой опыт и экспертиза российской практики. М.: ИСЭПН РАН; МЦГИ; «Русская панорама»; 328-351.

Вовк Е. 2006. Гендерная асимметрия и женские роли в современной России. Социальная реальность. 3: $61-73$.

Гурко Т. А. 2001. Трансформация брачно-семейных отношений. В сб.: Ядов В.А. (отв. ред.) Россия: трансформирующееся общество. М.: Канон-пресс-Ц; раздел 2, 272-283.

Дадаева Т. М. 2005. Кто выносит мусор, или Парадоксы гендерного разделения труда. Сочиологические исследования. 6: 120-126.

Захаров С. В. 2015. Браки и разводы в современной России. Демоскоn Weekly. 625-626. URL: http:// demoscope.ru/weekly/2015/0625/tema01.php

Здравомыслова О. М. 2003. Семья и общество: гендерное измерение российской трансформащии. М.: УРСС.

Зелизер В. 2002. Создание множественных денег. Экономическая социология. 3 (4): 58-72. URL: https:// ecsoc.hse.ru/data/2011/12/08/1208205038/ecsoc_t3_n4.pdf\#page=58

Ибрагимова Д. Х. 2012. Кто управляет деньгами в российских семьях. Экономическая соииология. 13 (3): 22-56. URL: https://ecsoc.hse.ru/data/2012/06/29/1255786111/ecsoc_t13_n3.pdf\#page=22

Ибрагимова Д. Х. 2016. Деньги, гендер, власть в домохозяйстве: концептуальные подходы. Экономическая соииология. 17 (2): 116-145. URL: https://ecsoc.hse.ru/data/2016/04/01/1126456877/ecsoc_t17_ n2.pdf\#page $=116$

Касаткин А. А. 2012. Развод в родительской семье как фактор формирования представления молодёжи о семейных отношениях. URL: http://www.ssa-rss.ru/files/File/congress2012/part21.pdf

Козер Л. 1956. Функи̧ии социиального конфликта. URL: http://do.gendocs.ru/docs/index-162369.html

Лыткина Т. С. 2004. Домашний труд и гендерное разделение власти. Социологические исследования. 9: $85-90$.

Маркс К., Энгельс Ф. 1955. Немецкая идеология. В изд.: Маркс К., Энгельс Ф. Сочинения: В 50 m. Т. 3. М.: Политиздат.

Назарова И. Б. 2007. Внерабочее время: возможности сохранения здоровья. Доклад на интернетконференциии «Охрана здоровья: проблемы организации, управления и уровни ответственности». URL: http://ecsocman.hse.ru/text/16206711/

Парсонс Т. 2000. О структуре соииального действия. М.: Академический проект.

Попова Д. О., Синявская О. В. 2011. Теоретические модели принятия решений в домохозяйстве. SPERO. 14: $121-142$. 
Танчер В. В. 1994. Льюис Козер: функциональность конфликта и польза несогласия в науке. В сб. Добреньков В. И. (отв. ред.) Современная американская социология. М.: Изд-во Московского университета; 265-273.

Тихомирова В. В. 2010. Социальное самочувствие и ценностные ориентации молодой семьи. Социологические исследования. 2: 118-124.

Addo F. R., Sassler S. 2010. Financial Arrangements and Relationship Quality in Low-Income Couples. Family Relations. 59 (4): 408-423.

Alsemgeest L. 2014. Family Communication about Money: Why the Taboo? Mediterranean Journal of Social Sciences. 5 (16): 516-523.

Amato P. R., Rogers S. J. 1997. A Longitudinal Study of Marital Problems and Subsequent Divorce. Journal of Marriage and the Family. 59: 612-624.

Belk R. W., Wallendorf M. 1990. The Sacred Meanings of Money. Journal of Economic Psychology. 11: $35-67$.

Berger L. M., McLanahan S. S. 2015. Income, Relationship Quality, and Parenting: Associations With Child Development in Two-Parent Families. Journal of Marriage and Family. 4 (77): 996-1015.

Blossfeld H.-P., Drobnič S. 2009. Theoretical Perspectives on Couples' Careers. In: Walter H. R., Huinink J., Weymann A. (eds) The Life Course Reader. Individuals and Societies across Time. Frankfurt; New York: Campus; $16-50$.

Booth A., Crouter A. C., Clements M. 2001. Couples in Conflict. Mahwah, NJ: Lawrence Erlbaum.

Britt S. L., Huston S. J. 2012. The Role of Money Arguments in Marriage. Journal of Family and Economic Issues. 33 (4): 464-476.

Burgoyne C. B. et al. 2007. Money Management Systems in Early Marriage: Factors Influencing Change and Stability. Journal of Economic Psychology. 28 (2): 214-228.

Carrère S., Gottman J. M. 1999. Predicting Divorce among Newlyweds from the First Three Minutes of a Marital Conflict Discussion. Family Process. 3 (38): 293-301.

Christensen A., Heavey C. L. 1990. Gender and Social Structure in the Demand/Withdraw Pattern of Marital Conflict. Journal of Personality and Social Psychology. 59 (1): 73-81.

Clarke S. 2002. Budgetary Management in Russian Households. Sociology. 36 (3): 539-557.

Coleman J. S. 1990. Foundations of Social Theory. Cambridge, MA; London, GB: The Belknap Press of Harvard University Press.

Conger R. D. et al. 1994. Economic Stress, Coercive Family Process, and Developmental Problems of Adolescents. Child Development. 65: 541-561. 
Crohan S. E. 1996. Marital Quality and Conflict Across the Transition to Parenthood in African American and White Couples. Journal of Marriage and Family. 4 (58): 933-944.

Cubbins L. A., Vannoy D. 2004. Division of Household Labor as a Source of Contention for Married and Cohabiting Couples in Metropolitan Moscow. Journal of Family Issues. 25 (2): 182-215.

Deutsch F., Roksa J., Meeske C. 2003. How Gender Counts when Couples Count their Money. Sex Roles. 48 (7/8): 291-304.

Dew J. P. 2009. The Gendered Meanings of Assets for Divorce. Journal of Family and Economic Issues. 30: $20-31$.

Dew J. P. 2011. The Association between Consumer Debt and the Likelihood of Divorce. Journal of Family and Economic Issues. 32: 554-565.

Dew J., Britt S., Huston S. 2012. Examining the Relationship Between Financial Issues and Divorce. Family Relations. 61 (4): 615-628.

Dew J., Dakin J. 2011. Financial Disagreements and Marital Conflict Tactics. Journal of Financial Therapy. 2 (1): $23-42$.

Driver J. L., Gottman J. M. 2004. Daily Marital Interactions and Positive Affect During Marital Conflict Among Newlywed Couples. Family Process. 3 (43): 301-314.

Ferber R., Lee L. C. 1974. Husband-Wife Influence in Family Purchasing Behavior. Journal of Consumer Research. 1 (1): 43-50.

Fincham F. D. 2003. Marital Conflict: Correlates, Structure, and Context. Current Directions in Psychological Science. 1 (12): 23-27.

Goffman E. 1977. The Arrangement between the Sexes. Theory and Society. 4 (3): 301-331.

Gottman J. M. 1994. What Predicts Divorce? The Relationship between Marital Processes and Marital Outcomes. Hillsdale, NJ: Erlbaum.

Halpern-Meekin S., Turney K. 2016. Relationship Churning and Parenting Stress Among Mothers and Fathers. Journal of Marriage and Family. 3 (78): 715-729.

Heavey C. L., Layne C., Christensen A. 1993. Gender and Conflict Structure in Marital Interaction: AReplication and Extension. Journal of Consulting and Clinical Psychology. 61 (1): 16-27.

Hira T. K., Loibl C. 2008. Gender Differences in Investment Behavior. In: Xiao J. J. (ed.) Handbook of Consumer Finance Research. New York: Springer; 253-270.

Huinink J. 2009. Linked Lives, Families, and Intergenerational Relations. In: Heinz W. R., Huinink J., Weymann A. (eds) The Life Course Reader: Individuals and Societies across Time. Frankfurt/Main: Campus; 303-310.

Ibragimova D., Guseva A. 2015. Who Is in Charge of Family Finances in the Russian Two-Earner Households? Journal of Family Issues. December 30; 1-24. 
Jenkins N. H. et al. 2002. You Paid how Much for That? How to Win at Money without Losing at Love. San Fransisco, CA: Jossey-Bass.

Kandel D. B., Davies M., Raveis V. H. 1985. The Stressfulness of Daily Social Roles for Women: Marital, Occupational and Household Roles. Journal of Health \& Social Behavior. 26 (1): 64-78.

Kenney C. T. 2006. The Power of the Purse Allocative Systems and Inequality in Couple Households. Gender \& Society. 20 (3): 354-381.

Kirchler E. 1990. Spouses' Influence Strategies in Purchase Decisions as Dependent on Conflict Type and Relationship Characteristics. Journal of Economic Psychology. 11 (1): 101-118.

Kirchler E. 1993. Spouses' Joint Purchase Decisions: Determinants of Influence Tactics for Muddling through the Process. Journal of Economic Psychology. 14 (2): 405-438.

Kirchler E. 1995. Studying Economic Decisions within Private Households: A Critical Review and Design for a "Couple Experiences Diary". Journal of Economic Psychology. 16 (3): 393-419.

Kirchler E. et al. 2001. Conflict and Decision-Making in Close Relationships. Love, Money and Daily Routines. Hove, UK: Psychology Press.

Kirchler E., Hoelzl E. 2011. Economic and Psychological Determinants of Consumer Behavior. ZeitschriftfürPsychologie/Journal of Psychology. 4 (219): 195-197.

Kluwer E. S., Johnson M. D. 2007. Conflict Frequency and Relationship Quality Across the Transition to Parenthood. Journal of Marriage and Family. 5 (69): 1089-1106.

Kluwer E. S., Heesink J. A. M., Van de Vliert E. 1996. Marital Conflict about the Division of Household Labor and Paid Work. Journal of Marriage and Family. 58 (4): 958-969.

Komter A. 1989. Hidden Power in Marriage. Gender \& Society. 3 (2): 187-216.

Lippe T. van der, Voorpostel M., Hewitt B. 2014. Disagreements among Cohabiting and Married Couples in 22 European Countries. Demographic Research. 10 (31): 247-274.

Margolin G., Gordis E. B., John R. S. 2001. Coparenting: A Link between Marital Conflict and Parenting in Two-Parent Families. Journal of Family Psychology. 1 (15): 3-21.

McGonagle K. A., Kessler R. C., Schilling E. A. 1992. The Frequency and Determinants of Marital Disagreements in a Community Sample. Journal of Social and Personal Relationships. 4 (9): 507-524.

McLanahan S., Percheski C. 2008. Family Structure and the Reproduction of Inequalities. Annual Review of Sociology. 34 (1): 257-276.

Pahl J. 1983. The Allocation of Money and the Structuring of Inequality within Marriage. The Sociological Review. 31 (2): 237-262.

Pahl J. 1990. Household Spending, Personal Spending and the Control of Money in Marriage. Sociology. 24 (1): 119-138. 
Pahl J. 1995. His Money, Her Money: Recent Research on Ffinancial Organisation in Marriage. Journal of Economic Psychology. 16 (3): 361-376.

Pahl J. 2005. Individualisation in Couple Finances: Who Pays for the Children? Social Policy and Society. 4 (04): 381-391.

Pahl J. 2008. Family Finances, Individualisation, Spending Patterns and Access to Credit. The Journal of Socio-Economics. 37 (2). Special Issue on the Household Economy: 577-591.

Papp L. M., Cummings E. M., Goeke-Morey M. C. 2009. For Richer, for Poorer: Money as a Topic of Marital Conflict in the Home. Family Relations. 1 (58): 91-103.

Ridgeway C. L. 2011. Gender at Home. In: Framed by Gender: How Gender Inequality Persists in the Modern World. New York: Oxford University Press; 127-155.

Shapiro M. 2007. Money: A Therapeutic Tool for Couples Therapy. Family Process. 46: 279-291.

Sun S. H.-L. 2010. The Final Say Is Not the Last Word: Gendered Patterns, Perceptions, and Processes in Household Decision Making among Chinese Immigrant Couples in Canada. Journal of Comparative Research in Anthropology and Sociology. 1 (1): 91-105.

Trentham S., Larwood L. 2001. Power and Gender Influences on Responsibility Attributions: The Case of Disagreements in Relationships. The Journal of Social Psychology. 141 (6): 730-751.

Vogler C. 1998. Money in the Household: Some Underlying Issues of Power. The Sociological Review. 46 (4): $687-713$.

Vogler C. 2005. Cohabiting Couples: Rethinking Money in the Household at the Beginning of the Twenty First Century. The Sociological Review. 53 (1): 1-29.

Vogler C., Brockmann M., Wiggins R. D. 2006. Intimate Relationships and Changing Patterns of Money Management at the Beginning of the Twenty-First Century. The British Journal of Sociology. 57 (3): 455-482.

Vogler C., Lyonette C., Wiggins R. D. 2008. Money, Power and Spending Decisions in Intimate relationships. The Sociological Review. 56 (1): 117-143.

Vogler C., Pahl J. 1993. Social and Economic Change and the Organisation of Money within Marriage. Work, Employment and Society. 7 (1): 71-95.

Vogler C., Pahl J. 1994. Money, Power and Inequality within Marriage. The Sociological Review. 42 (2): 263-288.

Zagorsky J. L. 2003. Husbands' and Wives' View of the Family Finances. The Journal of Socio-Economics. 32 (2): 127-146. 


\title{
PROFESSIONAL REVIEWS
}

\section{Polina Popova}

\section{How to Explain Financial Disagreements in Families: A Review of Economic, Psychological and Sociological Theories}

\author{
POPOVA, Polina - Master student, \\ the "Applied Methods of Social Analysis \\ of Markets"; Lecturer, Faculty of Social \\ Sciences; Manager, Laboratory for \\ Studies in Economic Sociology, National \\ Research University Higher School of \\ Economics. Address: 20 Myasnitskaya \\ str., Moscow, 101000, Russian \\ Federation.
}

\section{Email: papopova@hse.ru}

\begin{abstract}
Western literature identifies financial conflict as the main predictor of divorce in families and the most difficult and prolonged issue for spouses. However, the determinants of their occurrence remain a "blind spot" in the vast body of research devoted to marital conflicts and financial management. This article seeks to conceptualize financial conflict and to explain how it arises. The first part examines empirical studies of family conflicts and the role of money problems. Then, drawing on theories of family systems, family stress, social exchange, distribution of benefits, and role theory, the second part looks at the conflict formation process and possible
\end{abstract} predictors of financial conflict in the family. The third part of the review is devoted to a detailed examination of three factors in conflict formation at a theoretical level. The first of these is financial management and the opposition of independent strategies and pooling mechanisms. Continuing the theme of financial control, the next factor relates to concepts of power and how the grounds for its construction within a household contribute to financial conflict. The final factor is the gendered division of labor, which, according to a number of studies, is a key factor in marital dissatisfaction (especially for women) and the consequent emergence of conflict. The author concludes that these three factors are interrelated and require empirical verification as predictors of financial conflict in families.

Keywords: financial disagreements; marital conflict; money management; family power; division of labor; theories of family functions.

\section{Acknowledgements}

The research was supported by the Basic Research Program of the National Research University Higher School of Economics in 2017. The author would like to thank Dilyara Ibragimova, Ivan Pavlutkin, Elena Berdysheva, and Yana Roshchina for useful comments on the draft of this paper, and all the colleagues from the Laboratory for Studies in Economic Sociology who took part in the discussion of this research.

\section{References}

Addo F. R., Sassler S. (2010) Financial Arrangements and Relationship Quality in Low-Income Couples. Family Relations, vol. 59, no 4, pp. 408-423.

Alsemgeest L. (2014) Family Communication about Money: Why the Taboo? Mediterranean Journal of Social Sciences, vol. 5, no 16, pp. 516-523. 
Amato P. R., Rogers S. J. (1997) A Longitudinal Study of Marital Problems and Subsequent Divorce. Journal of Marriage and the Family, vol. 59, pp. 612-624.

Antonov A. I. (2012) Katastroficheskie izmeneniya instituta sem 'i i kraynyaya nastoyatel'nost' prosemeynoy politiki [Catastrophic Changes in the Family Institution and the Extreme Urgency of the Pro-Family Policy]. Available at: http://www.ssa-rss.ru/files/File/congress2012/part21.pdf (accessed 21 November 2016) (in Russian).

Belk R. W., Wallendorf M. (1990) The Sacred Meanings of Money. Journal of Economic Psychology, vol. 11, pp. 35-67.

Berger L. M., McLanahan S. S. (2015) Income, Relationship Quality, and Parenting: Associations With Child Development in Two-Parent Families. Journal of Marriage and Family, vol. 4, no 77, pp. 996-1015.

Blossfeld H.-P., Drobnič S. (2009) Theoretical Perspectives on Couples' Careers. The Life Course Reader. Individuals and Societies across Time (eds. W. R. Heinz, J. Huinink, A. Weymann), Frankfurt; New York: Campus, pp. 16-50.

Booth A., Crouter A. C., Clements M. (2001) Couples in Conflict, Mahwah, NJ: Lawrence Erlbaum.

Brines J. (2002) Ekonomicheskaya zavisimost', gender i domashnee razdelenie truda [Economic Dependence, Gender and the Division of Labor at Home]. Gender i ekonomika: mirovoy opyt $i$ ekspertiza rossiyskoy praktiki [Gender and Economics: World Experience and Expertise of Russian Practice] (ed. E. B. Mezentseva), Moscow: ISEPN RAN; MTsGI; Russkaya Panorama; pp. 328-351 (in Russian).

Britt S. L., Huston S. J. (2012) The Role of Money Arguments in Marriage. Journal of Family and Economic Issues, vol. 33, no 4, pp. 464-476.

Burgoyne C. B., Reibstein J., Edmunds A., Dolman V. (2007) Money Management Systems in Early Marriage: Factors Influencing Change and Stability. Journal of Economic Psychology, vol. 28, no 2, pp. 214-228.

Carrère S., Gottman J. M. (1999) Predicting Divorce among Newlyweds from the First Three Minutes of a Marital Conflict Discussion. Family Process, vol. 3, no 38, pp. 293-301.

Christensen A., Heavey C. L. (1990) Gender and Social Structure in the Demand/Withdraw Pattern of Marital Conflict. Journal of Personality and Social Psychology, vol. 59, no 1, pp. 73-81.

Clarke S. (2002) Budgetary Management in Russian Households. Sociology, vol. 36, no 3, pp. 539-557.

Coleman J. S. (1990) Foundations of Social Theory, Cambridge, MA; London, GB: The Belknap Press of Harvard University Press.

Conger R. D., Ge X., Elder G. H., Lorenz F. O., Simons R. L. (1994) Economic Stress, Coercive Family Process, and Developmental Problems of Adolescents. Child Development, vol. 65, pp. 541-561.

Coser L. (1956) Funktsii sotsial'nogo konflikta [Functions of Social Conflict]. Available at: http://do.gendocs. ru/docs/index-162369.html (accessed 15 January 2016) (in Russian).

Crohan S. E. (1996) Marital Quality and Conflict Across the Transition to Parenthood in African American and White Couples. Journal of Marriage and Family, vol. 4, no 58, pp. 933-944. 
Cubbins L. A., Vannoy D. (2004) Division of Household Labor as a Source of Contention for Married and Cohabiting Couples in Metropolitan Moscow. Journal of Family Issues, vol. 25, no 2, pp. 182-215.

Dadaeva T. M. (2005) Kto vynosit musor, ili Paradoksy gendernogo razdeleniya truda [Who Takes out the Garbage, Or The Paradoxes of the Gender Division of Labor]. Sotsiologicheskie issledovaniya, vol. 6, pp. 120-126 (in Russian).

Deutsch F., Roksa J., Meeske C. (2003) How Gender Counts When Couples Count Their Money. Sex Roles, vol. 48, no 7/8, pp. 291-304.

Dew J. P. (2009). The Gendered Meanings of Assets for Divorce. Journal of Family and Economic Issues, vol. 30, pp. 20-31.

Dew J. P. (2011) The Association between Consumer Debt and the Likelihood of Divorce. Journal of Family and Economic Issues, vol. 32, pp. 554-565.

Dew J., Britt S., Huston S. (2012) Examining the Relationship between Financial Issues and Divorce. Family Relations, vol. 61, no 4, pp. 615-628.

Dew J., Dakin J. (2011) Financial Disagreements and Marital Conflict Tactics. Journal of Financial Therapy, vol. 2, no 1, pp. 23-42.

Driver J. L., Gottman J. M. (2004) Daily Marital Interactions and Positive Affect During Marital Conflict Among Newlywed Couples. Family Process, vol. 3, no 43, pp. 301-314.

Ferber R., Lee L. C. (1974) Husband-Wife Influence in Family Purchasing Behavior. Journal of Consumer Research, vol. 1, no 1, pp. 43-50.

Fincham F. D. (2003) Marital Conflict: Correlates, Structure, and Context. Current Directions in Psychological Science, vol. 1, no 12, pp. 23-27.

Goffman E. (1977) The Arrangement between the Sexes. Theory and Society, vol. 4, no 3, pp. 301-331.

Gottman J. M. (1994) What Predicts Divorce? The Relationship between Marital Processes and Marital Outcomes, Hillsdale, NJ: Erlbaum.

Gurko T. A. (2001) Transformatsiya brachno-semeynykh otnosheniy [Transformation of Marriage and Family Relations]. Rossiya: transformiruyushcheesya obshchestvo [Russia: A Transforming Society] (ed. V. A. Yadov), Moscow: Kanon-press-Ts, Section 2, pp. 272-283 (in Russian).

Halpern-Meekin S., Turney K. (2016) Relationship Churning and Parenting Stress among Mothers and Fathers. Journal of Marriage and Family, vol. 3, no 78, pp. 715-729.

Heavey C. L., Layne C., Christensen A. (1993) Gender and Conflict Structure in Marital Interaction: A Replication and Extension. Journal of Consulting and Clinical Psychology, vol. 61, no 1, pp. 16-27.

Hira T. K., Loibl C. (2008) Gender Differences in Investment Behavior. Handbook of Consumer Finance Research (ed. J. J. Xiao), New York: Springer, pp. 253-270. 
Huinink J. (2009) Linked Lives, Families, and Intergenerational Relations. The Life Course Reader: Individuals and Societies across Time, Frankfurt/Main: Campus, pp. 303-310.

Ibragimova D. K. (2012) Kto upravlyaet den'gami v rossiyskikh sem'yakh [Who Manages Money in Russian Families]. Journal of Economic Sociology = Ekonomicheskaya sotsiologiya, vol. 13, no 3, pp. $22-56$. Available at: https://ecsoc.hse.ru/data/2012/06/29/1255786111/ecsoc_t13_n3.pdf\#page=22 (accessed 23 May 2016) (in Russian).

Ibragimova D. K. (2016) Den'gi, gender, vlast' v domokhozyaystve: kontseptual'nye podkhody [Money, Gender, Power in the Household: Conceptual Approaches]. Journal of Economic Sociology = Ekonomicheskaya sotsiologiya, vol. 17, no 2, pp. 116-145. Available at: https://ecsoc.hse.ru/data/2016/04/01/1126456877/ ecsoc_t17_n2.pdf\#page=116 (accessed 16 April 2016) (in Russian).

Ibragimova D., Guseva A. (2015) Who Is in Charge of Family Finances in the Russian Two-Earner Households? Journal of Family Issues, December 30, pp. 1-24.

Jenkins N. H., Stanley S. M., Bailey W. C., Markman H. J. (2002) You Paid how Much for That? How to Win at Money without Losing at Love, San Fransisco, CA: Jossey-Bass.

Kandel D. B., Davies M., Raveis V. H. (1985) The Stressfulness of Daily Social Roles for Women: Marital, Occupational and Household Roles. Journal of Health \& Social Behavior, vol. 26, no 1, pp. 64-78.

Kasatkin A. A. (2012) Razvod v roditel'skoy sem'e kak factor formirovaniya predstavleniya molodezhi o semeynykh otnosheniyakh [Divorce in the Parent Family as a Factor in Forming the Youth's Perception of Family Relationships]. Available at: http://www.ssa-rss.ru/files/File/congress2012/part21.pdf (accessed 11 February 2017) (in Russian).

Kenney C. T. (2006) The Power of the Purse Allocative Systems and Inequality in Couple Households. Gender \& Society, vol. 20, no 3, pp. 354-381.

Kirchler E. (1990) Spouses' Influence Strategies in Purchase Decisions as Dependent on Conflict Type and Relationship Characteristics. Journal of Economic Psychology, vol. 11, no 1, pp. 101-118.

Kirchler E. (1993) Spouses' Joint Purchase Decisions: Determinants of Influence Tactics for Muddling through the Process. Journal of Economic Psychology, vol. 14, no 2, pp. 405-438.

Kirchler E. (1995) Studying Economic Decisions within Private Households: A Critical Review and Design for a "Couple Experiences Diary". Journal of Economic Psychology, vol. 16, no 3, pp. 393-419.

Kirchler E., Hoelzl E. (2011) Economic and Psychological Determinants of Consumer Behavior. ZeitschriftfürPsychologie/Journal of Psychology, vol. 4, no 219, pp. 195-197.

Kirchler E., Rodler C., Hoelzl E., Meier K. (2001) Conflict and Decision-Making in Close Relationships. Love, Money and Daily Routines, Hove, UK: Psychology Press.

Kluwer E. S., Heesink J. A. M., Van de Vliert E. (1996) Marital Conflict about the Division of Household Labor and Paid Work. Journal of Marriage and Family, vol. 58, no 4, pp. 958-969.

Kluwer E. S., Johnson M. D. (2007) Conflict Frequency and Relationship Quality Across the Transition to Parenthood. Journal of Marriage and Family, vol. 5, no 69, pp. 1089-1106. 
Komter A. (1989) Hidden Power in Marriage. Gender \& Society, vol. 3, no 2, pp. 187-216.

Lippe T. van der, Voorpostel M., Hewitt B. (2014) Disagreements among Cohabiting and Married Couples in 22 European Countries. Demographic Research, vol. 10, no 31, pp. 247-274.

Lytkina T. S. (2004) Domashniy trud i gendernoe razdelenie vlasti [Domestic Work and Gender Division of Power]. Sotsiologicheskie issledovaniya, vol. 9, pp. 85-90 (in Russian).

Margolin G., Gordis E. B., John R. S. (2001) Coparenting: A Link between Marital Conflict and Parenting in Two-Parent Families. Journal of Family Psychology, vol. 1, no 15, pp. 3-21.

Marx K., Engels F. (1955) Nemetskaya ideologiya [German Ideology]. Sochineniya [Compositions]. 50 vols. Vol. 3, Moscow: Publishing House of Political Literature (in Russian).

McGonagle K. A., Kessler R. C., Schilling E. A. (1992) The Frequency and Determinants of Marital Disagreements in a Community Sample. Journal of Social and Personal Relationships, vol. 4, no 9, pp. 507-524.

McLanahan S., Percheski C. (2008) Family Structure and the Reproduction of Inequalities. Annual Review of Sociology, vol. 34, no 1, pp. 257-276.

Nazarova I. B. (2007) Vnerabochee vremya: vozmozhnosti sokhraneniya zdorov'ya [After Hours: Possibilities of Health Preservation]. Doklad na Internet-konferentsii “Okhrana zdorov'ya: problemy organizatsii, upravleniya i urovni otvetstvennosti" [Report at the Internet Conference "Health Protection: Organizational and Management Problems, and Responsibility Levels"]. Available at: http:/ecsocman.hse.ru/ text/16206711/ (accessed 18 February 2017) (in Russian).

Pahl J. (1983) The Allocation of Money and the Structuring of Inequality within Marriage. The Sociological Review, vol. 31, no 2, pp. 237-262.

Pahl J. (1990) Household Spending, Personal Spending and the Control of Money in Marriage. Sociology, vol. 24, no 1, pp. 119-138.

Pahl J. (1995) His Money, Her Money: Recent Research on Financial Organisation in Marriage. Journal of Economic Psychology, vol. 16, no 3, pp. 361-376.

Pahl J. (2005) Individualisation in Couple Finances: Who Pays for the Children? Social Policy and Society, vol. 4, no 04, pp. 381-391.

Pahl J. (2008) Family Finances, Individualisation, Spending Patterns and Access to Credit. The Journal of Socio-Economics, vol. 37, no 2 (Special Issue on the Household Economy), pp. 577-591.

Papp L. M., Cummings E. M., Goeke-Morey M. C. (2009) For Richer, for Poorer: Money as a Topic of Marital Conflict in the Home. Family Relations, vol. 1, no 58, pp. 91-103.

Parsons T. (2000) O strukture sotsial'nogo dejstviya [About Social Action Structure], Moscow: Akademicheskij proekt (in Russian).

Popova D. O., Sinyavskaya O. V. (2011) Teoreticheskie modeli prinyatiya resheniy v domokhozyaystve [Theoretical Models of Decision-Making in the Households]. SPERO, vol. 14, pp. 121-142 (in Russian). 
Ridgeway C. L. (2011) Gender at Home. Framed by Gender: How Gender Inequality Persists in the Modern World, New York: Oxford University Press, pp. 127-155.

Shapiro M. (2007) Money: A Therapeutic Tool for Couples Therapy. Family Process, vol. 46, pp. 279-291.

Sun S. H.-L. (2010) The Final Say Is Not the Last Word: Gendered Patterns, Perceptions, and Processes in Household Decision Making among Chinese Immigrant Couples in Canada. Journal of Comparative Research in Anthropology and Sociology, vol. 1, no 1, pp. 91-105.

Tancher V. V. (1994) L'yuis Coser: funktsional'nost' konflikta i pol'za nesoglasiya v nauke [Lewis Coser: The Functionality of Conflict and the Benefits of Disagreement in Science]. Sovremennaya amerikanskaya sotsiologiya [Contemporary American Sociology] (ed. V. I. Dobren'kov), Moscow: MSU Publishing House, pp. 265-273 (in Russian).

Tikhomirova V. V. (2010) Sotsial'noe samochuvstvie i tsennostnye orientatsii molodoy sem'i [Social WellBeing and Value Orientations of a Young Family]. Sotsiologicheskie issledovaniya, vol. 2, pp. 118-124 (in Russian).

Trentham S., Larwood L. (2001) Power and Gender Influences on Responsibility Attributions: The Case of Disagreements in Relationships. The Journal of Social Psychology, vol. 141, no 6, pp. 730-751.

Vogler C. (1998) Money in the Household: Some Underlying Issues of Power. The Sociological Review, vol. 46, no 4, pp. 687-713.

Vogler C. (2005) Cohabiting Couples: Rethinking Money in the Household at the Beginning of the Twenty First Century. The Sociological Review, vol. 53, no 1, pp. 1-29.

Vogler C., Brockmann M., Wiggins R. D. (2006) Intimate Relationships and Changing Patterns of Money Management at the Beginning of the Twenty-First Century. The British Journal of Sociology, vol. 57, no 3, pp. 455-482.

Vogler C., Lyonette C., Wiggins R. D. (2008) Money, Power and Spending Decisions in Intimate relationships. The Sociological Review, vol. 56, no 1, pp. 117-143.

Vogler C., Pahl J. (1993) Social and Economic Change and the Organisation of Money within Marriage. Work, Employment and Society, vol. 7, no 1, pp. 71-95.

Vogler C., Pahl J. (1994) Money, Power and Inequality within Marriage. The Sociological Review, vol. 42, no 2, pp. 263-288.

Vovk E. (2006) Gendernaya asimmetriya i zhenskie roli v sovremennoy Rossii [Gender Asymmetry and Women's Roles in Modern Russia]. Sotsial'naya real'nost', vol. 3, pp. 61-73 (in Russian).

Zagorsky J. L. (2003) Husbands' and Wives' View of the Family Finances. The Journal of Socio-Economics, vol. 32, no 2, pp. 127-146.

Zakharov S. V. (2015) Braki i razvody v sovremennoy Rossii [Marriages and Divorces in Modern Russia]. Demoscope Weekly, no 625-626. Available at: http://demoscope.ru/weekly/2015/0625/tema01.php (accessed 18 March 2017) (in Russian). 
Zdravomyslova O. M. (2003) Sem'ya i obshchestvo: gendernoe izmerenie rossiyskoy transformatsii [Family and Society: The Gender Dimension of the Russian Transformation], Moscow: URSS (in Russian).

Zelizer V. (2002) Sozdanie mnozhestvennykh deneg [Creating Multiple Money]. Journal of Economic Sociology $=$ Ekonomicheskaya sotsiologiya, vol. 3, no 4, pp. 58-72. Available at: https://ecsoc.hse.ru/ data/2011/12/08/1208205038/ecsoc_t3_n4.pdf\#page=58 (accessed 25 March 2016) (in Russian).

Received: September 20, 2016.

Citation: Popova P. (2017) Kak obyasnit' finansovyy konflikt v sem'e? Obzor ekonomicheskikh, psihologicheskikh i sotsiologicheskikh kontseptsiy [How to Explain Financial Disagreements in Families: A Review of Economic, Psychological and Sociological Theories], Journal of Economic Sociology = Ekonomicheskaya sotsiologiya, vol. 18, no 2, pp. 112-137. Available at https://ecsoc.hse. ru/2017-18-2.html (in Russian). 


\section{НОВЫЕ КНИГИ}

\section{Н. В. Конрой \\ Разумный альтруизм: можно ли примирить мораль и рынок?}

Рецензия на книгу: Berend Z. 2016. The Online World of Surrogacy.

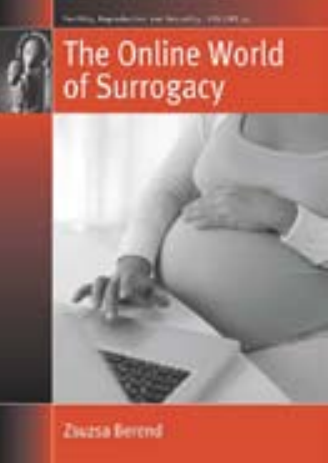
NY, Oxford: Berghahn Books. 270 p.

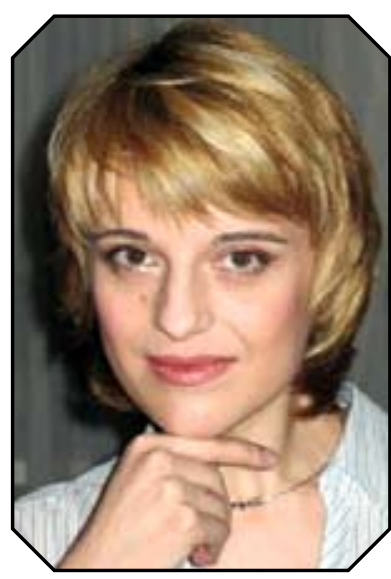

КОНРОЙ Наталья Викторовна кандидат исторических наук, научный сотрудник Лаборатории экономикосоциологических исследований (ЛЭСИ) Национального исследовательского университета «Высшая школа экономики». Адрес: 101000, Россия, г. Москва, ул. Мясницкая, д. 20.

Email: nconroy@hse.ru
Книга Жужи Беренд - результат десятилетней этнографии речевого поведения необычной группы, которая называла себя «удивительные женщиины SMO» ${ }^{1}$ (www.surromomsonline.com). Это не первое, но одно из самых продолжительных исследований как американского суррогатного материнства, так и сочиальной динамики онлайн-дискуссий, и поэтому, уверена, книга станет обязательной для чтения исследователями с очень разными интересами. Основные паттерны обсуждений, инициируемых участнииями SMO, оказались связаны с такими близкими экономической антропологии и экономической сочиологии понятиями, как родительство и материнство, работа и отношения, контракт и деньги, товар и дар. Суррогатные матери и бездетные пары, вступавшие в диалог без посредников (точнее - через Интернет), пытались договориться о моральном содержании этих понятий в контексте рыночных отношений, объединивших их общей целью рождения ребёнка. Беренд, наблюдавшая онлайн за усилиями чужих друг другу людей по выработке экономических и нравственных оснований для взаимовыгодного проекта, пыталась в переговорных микрособытиях найти ответ на вопрос о том, можно ли примирить мораль и рынок. Хотя автор использовала некоторые теоретические концепты (в том числе принадлежащие полю экономической сочиологии), они были для неё, скорее, сенсибилизирующими понятиями, помогающими интерпретировать полевой материал, не отрываясь сильно от мира SMO. Богатый эмпирический материал не был безжалостно пропущен сквозь мелкое сито одной или двух теорий, автор оставила читателю достаточно данных для собственных интерпретаций. В то же время, как представляется, найденный Беренд ответ раскрывается в понимании суррогатными матерями реального $и$ (или) разумного альтруизма, с помощью которого они переосмысливают реципрокные отношения и балансируют отданное и полученное.

Ключевые слова: вспомогательная репродукция; суррогатное материнство; родство; отношенческая работа; моральные рынки; договор; деньги; дар; альтруизм.

В последнее десятилетие наблюдается расцвет качественных исследований новых репродуктивных практик (далее - НРП) - экстракорпорального оплодотворения (ЭКО - in vitro fertilization, IVF), сонограммы, амниоцен-

Surrogate Mothers Online (SMO) — самый посещаемый в США модерируемый интернетресурс, посвящённый суррогатному материнству. 
теза, донорства спермы и яйцеклеток, преимплантационного генетического тестирования и генетического консультирования. Прошлый 2016 год оказался примечателен выходом сразу двух серьёзных этнографий, посвящённых суррогатному материнству (далее - CM) ${ }^{2}$. Одна принадлежит Хэзер Джейкобсон [Jacobson 2016] из Техасского университета, другая - Жуже Беренд из Калифорнийского университета в Лос-Анджелесе. Моё внимание привлекла книга Ж. Беренд; поначалу не столько из интереса к СМ, сколько из любопытства к «месту» и технике проведённого ею исследования, о которых я расскажу чуть позже.

Беренд отмечает, что в ранних исследованиях СМ прослеживались тревожные мотивы грядущих опасностей (появление «репродуктивных притонов», коммодификация материнства, ужесточение патриархального контроля над женщинами). Критики были уверены, что жизненные обстоятельства подтолкнут к СМ финансово нуждающихся и уязвимых для эксплуатации более образованными и состоятельными парами женщин. В то же время перспективы самих суррогатных матерей ${ }^{3}$ в этих исследованиях ещё не были представлены.

Обращаясь к своему исследованию, Беренд поясняет, что его предопределили вопросы, которыми задавались её американские коллеги, и считает, что в эмпирическом смысле продолжила этнографии, сделанные Хеленой Рагони и Элизабет Робертс. Рагони два года наблюдала и интервьюировала различных участников нового тогда рынка: директоров и сотрудников СМ-программ, суррогатных матерей и бездетные пары, желающие стать родителями (intended parents, IPs). Её интересовали не только функционирование программ, но и чувства, мотивация, ожидания информантов, их культурная работа по переосмыслению понятий родства. В результате она пришла к выводу, что основой современного американского родительства является намерение (intent). В то же время это переосмысление родства не было революционным, напротив, оно подчёркивало те элементы, которые были близки присущему среднему классу пониманию семейных отношений как основанных на любви, воспитании и обязательстве. Робертс, которая проводила исследование в одном из калифорнийских агентств, выяснила, что суррогатные матери гордятся своей фертильностью и расценивают её как актив и источник власти, нивелирующий социально-экономические различия между ними и бездетными парами. Робертс ввела понятие «нарративная власть», которое оказалось полезным Беренд в её анализе.

Беренд отмечает, что со времени первых этнографий изменились не только технологии и практики, но и организационное поле НРП. Появилось множество новых агентств, юристов, клиник и независимых репродуктивных брокеров, выросла конкуренция. Интернет превратился в форум, поставляющий информацию о повседневных аспектах СМ. В то же время были проведены качественные исследования СМ в других странах (Индия, Израиль), которые показали инсайдерский взгляд суррогатных матерей на их практики и сделали возможными межкультурные сравнения моделей $\mathrm{CM}^{4}$. Эти работы открыли

2 Первые этнографии СМ появились уже в 1990-х гг. (см.: [Ragoné 1994; Roberts 1998]), с возникновением самих технологий, и продолжали выходить по мере развития этого поля (см., например: [Teman 2010; Pande 2014]).

3 Важно отметить, что Беренд и её информантки не используют понятие «суррогатная мать» (surrogate mother). Это связано с тем, что практикующие СМ женщины проводят чёткую границу между суррогатным вынашиванием ребёнка и материнством, поскольку материнство возникает не вследствие вынашивания или генетического родства, а как результат желания (намерения) быть матерью ребёнка. На SMO для обозначения практикующей СМ женщины используются либо термин surrogate (суррогатная), либо более короткое самоназвание участниц — сурро (surro). Придерживаясь норм русского языка, я буду использовать либо самоназвание женщин, либо термин «суррогатная мать» в значении «вынашивающая ребёнка женщина, не являющаяся его матерью».

4 Расширение поля СМ, которое заметили, безусловно, не только исследователи, но и СМИ, показательно повлияло на динамику медийной оценки СМ в США. При том, что, как отмечает Беренд, на протяжении десятилетия медиа удостаивали СМ негативными комментариями, рост индийского СМ резко поднял статус американских суррогатных матерей в американских СМИ. Теперь американки стали рассматриваться прессой как альтруистки, а индианки - изображаться как бедные и нуждающиеся женщины, беспринципно торгующие телом. 
сложную картину отношений, интересов, эмоций участниц, оспаривающих крайности внешних представлений о СМ (коммодификация $v s$ альтруизм).

\section{Виртуальная этнография мира суррогатных}

Путь Беренд в это поле очаровывает своей типичной для хороших этнографий «случайностью». Её предыдущие работы были посвящены незамужним женщинам XIX века и их пониманию любви, обязанностей, работы, денег и семьи. Переехав в Лос-Анджелес, она начала преподавать курс социологии семьи, в котором использовала фрагмент из этнографии Рагони. Когда одна из студенток решила делать исследование СМ на www.surromomsonline.com (далее - SMO), Беренд тоже зарегистрировалась на сайте, чтобы помочь своей подопечной. Чтение постов и дискуссий напомнило ей опыт архивной работы. Часть того, что она узнала, подтверждало наблюдения Рагони, однако на SMO не было посредников: женщины представляли саморегулируемую группу, брали на себя функции продвижения СМ и социального контроля. По словам Беренд, её заинтересовали эти совместные усилия по определению и балансированию эгоизма и альтруизма, получения и отдачи.

В период исследования Беренд поиск вариантов «без посредников» (going indy) набирал популярность с обеих сторон ${ }^{5}$. Постепенно SMO стал главной площадкой, где женщины размещали рекламные объявления и переписывались с множеством потенциальных родителей. Одна из ключевых информанток Беренд сравнивала эту переписку с обменом сообщениями на сайтах знакомств (с той разницей, что предметом обсуждения были не свидания, а дети). Язык любви заимствовали не только суррогатные матери, но и некоторые потенциальные родители (точнее - матери). Однако суррогатные матери шли намного дальше: они искали «идеального совпадения», пару своей мечты, с которой будут выстраивать романтические отношения. Они были очень чувствительны как к знакам, которые в ходе знакомства подавали потенциальные родители, так и к собственным ощущениям («щёлкнуло» ли, проскочила ли искра?).

По мере погружения в жизнь SMO Беренд поняла, что онлайн-форум представлял собой место встречи женщин, разделяющих мечту помочь бесплодным и бездетным парам стать родителями ${ }^{6}$. Ветки форума обучали женщин, чего им ожидать и хотеть, о чём мечтать. Женщины повторяли, что хотят видеть счастливые лица и слёзы на глазах своей пары, держащей ребёнка. Этот наиболее сильный образ СМ был сформирован женщинами коллективно, а само СМ определено как последовательность целенаправленных действий, ведущих к запечатлённой в этом образе мечте.

По словам форумчанок, помощь людям в создании семьи затягивает. Как шутит Беренд, она сама, подобно её героиням, оказалась втянута в жизнь SMO и однажды поймала себя на том, что заходит на сайт, чтобы узнать, что делают её сурро. Те делились своими впечатлениями от общения с потенциальными родителями, условиями контрактов, течением беременности, историями родов; шли на финансовые и прочие компромиссы ради своей пары, публиковали фотографии своих сурродетей, а также подарков и цветов, полученных от родителей. В то же время на сайте было много постов о выкидышах, о чувстве одиночества и вины, историй предательства и разочарования в романтических отношениях со своей парой, рассказов о потере денег или работы.

5 Сайт был основан в 1997 г.; в 2002 г. на нём были зарегистрированы 800 пользователей; в 2007-м - 30 тыс. пользователей. Активными участниками дискуссий, как правило, были суррогатные и потенциальные матери. Потенциальные отцы редко принимали участие в обсуждениях, практически всегда это были геи.

6 Героини Беренд определяют бесплодие предельно широко (неспособность иметь детей, достижение нефертильного возраста, невозможность иметь так много детей, как хочется, гомосексуальный брак), и это формирует их эмпатию и намерение помочь. 
SMO для суррогатных матерей был одновременно инструментом обучения, механизмом поддержки и признания, средством нормализации СМ и связанных с ним эмоций. На протяжении всей книги Беренд показывает, как в коммуникациях на SMO женщины балансировали два коллективных определения $\mathrm{CM}$ - как особенных отношений уникальных людей и как практики, выходящей за границы конкретных соглашений индивидов. Они обсуждали свою любовь и совершенно специфические отношения со своей парой, но также и универсальные обязанности, действия и эмоциональные реакции, возникающие в отношениях СМ. В процессе таких обсуждений женщины формировали эмоциональное, отношенческое, медицинское и правовое знание, коллективно вырабатывали этос СМ, разрешали вопросы о чувствах и поведении в различных ситуациях и определяли, что значит «быть хорошей сурро». Беренд подчёркивает, что женщины делали это неспециально, но это не было и побочным продуктом общения, связанного с поддержкой и советами.

Беренд видит в SMO семиотическое сообщество [Sewell 1999] и «структуру возможностей» для конструирования и согласования смыслов вспомогательных репродуктивных технологий (assisted reproduction). Однако смыслы, как утверждал Г. А. Файн (см., например: [Fine 2010]), никогда не согласовываются «с нуля», поэтому Беренд последовательно вписывает дискуссии суррогатных матерей в фреймы и представления, формируемые агентствами, врачами, юристами, а также в более широкие культурные понимания жизни, семьи, родства, близости и репродукции, разделяемые представителями американского среднего класса.

Исследовательница сфокусировалась на коммуникации ${ }^{7}$, ушла от уникальных историй ${ }^{8}$ и вывела на первый план творческий процесс определения СМ и самоопределения сурро ${ }^{9}$, свидетелем которого она была в течение - ни много ни мало! - 10 лет. Наряду со смысловыми паттернами дискуссий Беренд выделяла их тональности. Она наблюдала лингвистическое поведение участников пассивно, не вмешиваясь в дискуссии и не задавая повестку дня. В отличие от многих коллег, делающих экспрессэтнографии онлайн-миров, Беренд не спрашивала женщин, как они используют сайт и что думают о своём пребывании на нем. Она постепенно «выуживала» ответы из живых постов и дискуссий, наблюдала за тем, какие вопросы настойчиво повторялись участницами, к каким темам они многократно возвращались, какие сообщения больше просматривали.

За 10 лет она всего дважды обратилась к сурро: около 35 человек откликнулись по электронной почте, с одной женщиной Беренд встретилась лично. В интервью и письмах она проясняла только то, что требовало уточнения. Все, кроме пяти женщин, с которыми она контактировала, имели постоянную работу (в основном секретарскую или в службах поддержки) и относили себя к среднему классу. Четверо были разведёнными матерями, остальные - замужними матерями двоих и более детей. Многие из участниц дискуссий на SMO обладали впечатляющим запасом юридических и медицинских знаний, гордились своей информированностью и способностью сознательно принимать риски.

Периодически участницы SMO инициировали собственные опросы, что позволило Беренд дополнить социально-демографический портрет сурро. Почти все были белыми женщинами в возрасте 25-39 лет, христианками, либерально настроенными к геям. Их общей самохарактеристикой являлась «духовность» (spiritual). Относительно немногие не делали прививки своим детям, некоторые подходили к вакцинации избирательно. В ответах о среднем доходе своей семьи без учёта денег за СМ женщины указывали «более 40 тыс. дол», а ответах на вопросы об образовании - уровень выше среднего. Де-

7 Её работа написана в перспективах Чикагской школы, И. Гоффмана и символического интеракционизма.

8 Несомненное влияние Гэри Алана Файна.

9 Беренд анализирует этот процесс в гирцевском понимании создания культуры как паутины разделяемых и уточняемых смыслов. 
сятилетний лингвистический анализ также позволил Беренд утверждать, что большинство участниц дискуссий принадлежало к низшему среднему и среднему классам (а не к нуждающимся, как считали некоторые критики СМ).

\section{Обоснованная теория онлайн-мира суррогатных}

Для анализа «этнонарративов» женщин Беренд использовала техники обоснованной теории. Так, например, приоткрывая свою аналитическую кухню, она поясняет, что её первоначальная категория «разочарование в IPs» оказалась слишком широкой: при том, что в большинстве случаев сурро получали поддержку товарок в ответ на жалобы, в некоторых ситуациях ответы носили характер резкой отповеди. Категория распалась на две: «Разочарование в IPs, не сдержавших обещания или нарушивших соглашения» и «Разочарование в IPs, не оправдавших надежд сурро на поддержку и сочувствие». Первый случай всегда вызывал сочувственное понимание, второй — критику, поскольку согласно этике поля «хорошая» сурро должна быть достаточно сильной, информированной, независимой и любящей, чтобы справляться с неидеальными ситуациями.

Найти смыслы в огромных массивах данных Беренд также помогали техники написания мемо. Например, благодаря мемо она выделила две категории жалоб на SMO: «выплёскивание», «выпускание пара» (venting или vents) - жалобы тех, кто одновременно утверждает ценности суррогатного материнства, и «нытьё» (whining) — жалобы в чистом виде, которые вызывали у женщин смешанную реакцию. «Выпускание пара» обычно получало поддержку («It's OK to vent, honey!», то есть «Выпустить пар — это нормально, милая!»), поскольку отвечало идеалу сурро и демонстрировало решимость продолжать, силу и щедрость.

Жужа Беренд увидела американское СМ как моральный проект суррогатной матери и её пары, который обсуждается через ценностные понятия хорошо или плохо, соответствует или не соответствует и может интерпретироваться в категориях моральных рынков (moralized markets) М. Фуркад и К. Хили.

Свой эмпирический вопрос Беренд сформулировала широко: как дар и рыночный обмен связаны с моральными ценностями? Ответ на него она даёт в основной части книги. Я кратко суммирую моё видение этого ответа, но сначала обозначу важные для понимания американского СМ представления о родстве, выделенные Ж. Беренд на SMO.

\section{Родство в понимании американских сурро}

Базовой посылкой участниц SMO являлось то, что ни генетическое родство (relatedness), ни беременность (gestation) не создают материнства. Суррогатный ребёнок всегда принадлежит родителям, и ничто не может это изменить. Акцентируя свою важную, но не главную роль в процессе создания ребёнка, сурро говорят о себе: «Я — печь», «Я —инкубатор», «Я — няня» (babysitter). В основе СМ лежат желания родителей иметь ребёнка и суррогатной матери - помочь им. Беренд подчёркивает, что в США родство реконцептуализируется как намерение, желание и любовь; в таком же направлении на протяжении 10 лет её наблюдений переосмысливалось СМ. Жажда быть родителями является «естественным» и порождает основание родства (kinship) и родительства (parenthood).

В соответствии с таким пониманием, женщины на SMO выстраивали отношения и связи с родителями, а не с ребёнком («IPs, а не ребёнок, должны быть твоими, а ты - их!»). Они надеялись, что их дружба и связь с парой сохранятся после рождения ребёнка («Конечно, я интересуюсь ребёнком, но ими я интересуюсь больше!»). Сурро апеллировали не к материнским чувствам, а к обязательствам, к 
своему намерению (intent) помочь бездетной паре и к намерению пары стать родителями («СМ вращается вокруг намерения»). Генетическое родство традиционной суррогатной матери с ребёнком на SMO переопределялось в фиктивное родство двух женщин - сурро и матери, которые позиционировались как сёстры. Ребёнок являлся связующим звеном в этом выбранном сестринстве. В логике сурро, в процесс создания ребёнка вовлечены две семьи; дети для них — продукт брака, поэтому они не считают суррогатных детей сиблингами своих собственных даже в тех случаях, когда являются донорами биологического материала ${ }^{10}$.

В главах «Путешествие» («Journey»), «Договор» («Contract»), «Деньги» («Money») и «Дар» («Gift») Беренд показывает, как через противопоставление денежных ценностей и священности жизни женщины дискурсивно создавали и поддерживали моральную ценность и цели СМ.

\section{Романтическое путешествие «всё включено» - за ребёнком}

Главное понятие, вокруг которого суррогатные на SMO выстраивали и осмысляли свой опыт, — это «путешествие» (journey), которое начинается решением женщины стать сурро ${ }^{11}$ и поиском «своей» пары, а заканчивается рождением суррогатного ребёнка и передачей его родителям. В идеальных представлениях сурро такое путешествие - многократно повторяющийся опыт ${ }^{12}$. Нарративы о путешествиях и их отдельных этапах - важный жанр SMO. Путешествие переживается эмоционально как разделённая (опять же в идеале) или неразделённая любовь, но в общении с партнёрами женщинам приходится балансировать эмоции и ожидаемую от них рациональность (предсказуемость, ответственность, соблюдение договорных обязательств). Как отмечает Беренд, дилемма путешествия сурро заключается в том, что проявляя рациональность, она рискует навлечь на себя обвинения в калькулятивности и коммодификации, а проявляя эмоциональность - вызвать сомнения в своей адекватности и надёжности.

Несмотря на то что СМ осмыслялось через уникальный опыт каждого путешествия, юридически женщины стремились к стандартизации. Они сравнивали договоры, повышали правовую грамотность, нанимали юристов. Договор рассматривался ими как первый важный рубеж путешествия. Хотя в дискуссиях сурро говорили о контрактах как неудобной для себя теме, неинформированность и пренебрежение правовой стороной отношений на SMO всегда осуждались.

Стандартные суррогатные контракты чрезвычайно детализированы и состоят из 30-60 страниц текста, оговаривающего множество условий и ответственностей, в том числе за пределами денежных обязательств. Утверждается количество попыток достижения беременности и трансплантируемых эмбрионов, предусмотрен раздел ограничений, накладываемых на жизненный стиль суррогатной матери на период беременности (путешествия, напитки, еда, секс, медицинские препараты, иногда даже окрашивание волос) и др.

10 Таким образом, как справедливо отмечает Беренд, детальное изучение отношений сиблингов может многое прояснить в понимании того, как производится современное американское родство.

11 Вполне предсказуемо, женщины осмысляют свой выбор «дарить жизнь» и свою карьеру сурро в категориях судьбы (meant to be) и призвания (calling).

12 На практике далеко не каждой удаётся пройти полностью даже одно путешествие, не в последнюю очередь из-за технической сложности достижения беременности и вынашивания суррогатного ребёнка. За опыт попыток статус ветерана на SMO может получить и та, кто не закончила путешествие, хотя об ограниченности её опыта ей всё же будут напоминать. Некоторые сурро проходят через три полных цикла, иногда - многоплодных беременностей. Готовность продолжать столько, сколько позволит здоровье, и двигаться к цели и главной награде своего путешествия (рождению ребёнка и созданию полной семьи для своей пары) - одна из главных нравственных установок участниц. 
Стандартной договорной схеме «всё включено», предусматривающей выплату компенсации 25-40 тыс. дол., сурро предпочитали схему основных и дополнительных расходов, которая определяет базу в $15-$ 25 тыс. дол. В то же время женщины считали неудобным оговаривать длинный перечень возможных дополнительных расходов, поскольку в их глазах это коммерциализировало отношения и путешествие. Они сознательно шли на финансовые потери, приписывая контрактам первого типа качества опасной и дорогой азартной игры, гэмблинга. Некоторые пытались найти компромиссный вариант и заключали договор по схеме «все включено», прилагая к нему лист дополнительных расходов, которые могут быть вычтены из суммы договора в случае, если события не произойдут.

Как правило, контракты устанавливают периодичность и размеры платежей. Сурро предпочитали 8-10 равных выплат, чтобы гарантированно получить компенсацию за пройдённую часть путешествия в случае выкидыша. Женщины с подозрением относились к предложениям единовременной оплаты по факту, в том числе и потому, что в их глазах это превращало процесс в «продажу» родившегося ребёнка, а они настаивали на том, что оплата является компенсацией их времени, боли и страданий.

Суррогатные матери признавали, что не любят стадию подготовки договора за её рыночный, рациональный характер; они беспокоились о том, что могут выглядеть жадными, и иногда предпочитали согласиться на невыгодные и несправедливые для себя условия, чтобы не огорчать свою пару. В конфликте сердца и денег они часто выбирали сторону сердца, им требовалось серьёзное обоснование того, что забота о себе не является бездушной.

Беренд полагает, что женщины в этом поле чаще ориентированы на минимизацию потерь, чем на максимизацию прибыли, поскольку в СМ сложно просчитать возможные потери и осложнения: каждая суррогатная беременность сильно отличается как от естественной, так и от другой суррогатной беременности, и не позволяет женщинам ориентироваться в оценках на свой предыдущий опыт. Сурро постоянно предупреждали и предостерегали друг друга от поспешных решений, что, по мнению Беренд, свидетельствует о том, что многие были готовы кинуться осуществлять чужую мечту до того, как просчитали риски других сторон, вовлечённых в процесс (например, собственных детей). Автор ссылается на Джиллиан Хадфилд, которая поставила под сомнение универсальность конвенционального понимания контракта, утверждая, что наши выборы должны оцениваться не только количественно, но и качественно, поскольку выражают и конструируют нашу сущность [Hadfield 1998]. Участницы SMO говорили о том, что их решение помочь связано с глубоким сочувствием по отношению к тем, кто бесплоден (и, значит, не имеет полноценной семьи). Подобное сочувствие не уникально: особенными в своих глазах сурро делало то, что сочувствие заставляет их действовать.

Женщины считали, что в СМ переплетены бизнес и личные отношения, и отношенческие аспекты контракта для них чрезвычайно важны: обсуждение условий поднимает на поверхность худшее в людях и имеет для сурро прогностическую ценность. Женщины часто аргументировали свой подход тем, что никто не вступает в брак, думая о разводе, но разводы случаются (сравнение СМ с браком типично для $\mathrm{SMO}$ ). Переговоры - это тест отношений, характеров, проверка совместимости. Женщины подавали паре сигналы о своём сочувствии и готовности отдавать, ожидая ответной реципрокности, то есть уважения и учёта интересов её семьи.

\section{Родительство в подарок}

Одна из постоянно обсуждавшихся тем - как не быть слишком отдающей, то есть не отдавать больше, чем собиралась и чем прописано в договоре. Женщины часто оказывались без компенсации в случае выкидыша, так как не оговаривали эту ситуацию в договоре, или вводили в расходы собственную семью, потому что постеснялись упомянуть в контракте возможность потери трудоспособности. 
Участницы призывали друг друга не снижать компенсационные выплаты «ради любви» к своей паре и помнить о своих близких и балансе интересов. Современные суррогатные матери активно вносят изменения в контракты и нанимают юристов, на форуме поддерживают тех, кто «тщательно делает свою домашнюю работу» и учится на ошибках; осуждают тех, кто спешит заключить типовой договор.

Со временем женщины также стали уделять больше внимания нефинансовым положениям договоров, касающимся многоплодной беременности, удаления части эмбрионов и искусственного прерывания беременности. По идеальным представлениям сурро они вынашивают детей для достойной пары, которая отчаянно желает ребёнка, поэтому когда в реальности оказывается иначе, им трудно это принять. Типовой договор никак не помогает решению подобных проблем и вынуждает суррогатных занять какую-то нравственную позицию. Беренд видит тенденцию отхода от простого морального выбора «это не мой ребёнок и не моё решение». Годы обсуждения историй о разбитых сердцах и раскаянии способствовали выработке участницами разделяемого чувства ответственности за созданную жизнь, в котором сочетаются признание как безусловного родительства пары, так и нравственной или пролайфистской позиции суррогатной матери. Это чувство, как правило, и противоречит положениям типового контракта, и разрушает во всех других ситуациях тщательно выстроенную дистанцию между сурро и ребёнком, которого она вынашивает.

Беренд пишет, что, вопреки существующим теориям контракта, её данные свидетельствуют: суррогатные матери и будущие родители не всегда видят договор одинаково и стремятся к достижению одних целей; более того, они не осознают этого в ходе переговоров. Обе стороны сфокусированы на создании ребёнка. Для родителей ребёнок - цель и благо. Цель суррогатных матерей сложнее. Они ожидают от своей пары эмоционального удовлетворения и аффективной оплаты, а также справедливой денежной компенсации. Женщины больше инвестируют в осуществление чужой мечты, чем в защиту своих интересов, многие важные для них вещи находятся за пределами контрактного регулирования. Родители же не всегда считают, что они должны аффективную оплату своим суррогатным матерям.

По мнению Беренд, основное противоречие СМ заключается в том, что оно регулируется договором, а понимается как дар. В отличие от Рагони, которая пришла к выводу, что как дар сурро определяют детей, вынашиваемых для бездетной пары, Беренд утверждает, что сурро дарят родительство. Этот дар предполагает реципрокность и ответную благодарность родителей, что означает для сурро поддержание отношений с ней и её семьёй после получения ребёнка. Реципрокность означает выход за рамки формального договора, и в логике дара родители суррогатного ребёнка не могут выбрать «не быть обязанными», но могут быть неблагодарными. Вступая в формальный договор с парой, сурро надеются на реципрокные отношения длиною в жизнь, то есть на равенство и дружбу, а также рассчитывают на признание неперекрываемой деньгами жертвы, которую принесли они и их семьи ради появления новой жизни.

Дискуссии на SMO показывали, что женщины были удовлетворены, когда их ценили и выражали им признательность, и разочарованы, когда родители разрывали связи и отрицали их жертву. Эмоциональные дивиденды в последнем случае женщины получали на SMO, где обменивали неуважение потенциальных родителей на признание товарок. Такая конвертация позволяла женщинам представлять себя и свой случай в сбалансированной манере и поддерживать коллективно одобряемый имидж умной, сильной и альтруистичной женщины, стоящей выше мира рынка.

\section{Разумный альтруизм}

$\mathrm{CM}$ часто путают с отношениями коммодицикации тела и с материнством, поэтому участницы форума прилагали значительные усилия, чтобы провести границы и установить различия, в том числе - через 
дифференциацию денежного возмещения. Они выделяли три вида платежей: (1) возмещение стандартных расходов; (2) оплата непредвиденных расходов, вызванных нештатными ситуациями; (3) компенсация за боль и страдания. При этом ни один из видов возмещения не понимался как цена ребёнка или услуги по его вынашиванию. Женщины противопоставляли цену и бесценность (проституция имеет цену, ребёнок - нет; проституткой может быть любая, сурро - только та, кто заботится о других и является хорошим человеком).

Тем не менее деньги в поле ВРТ (вспомогательные репродуктивные технологии) во многих неопределённых ситуациях, несомненно, выступали критерием для оценки таких ситуаций. Так, например, по количеству средств, затраченных бездетной парой на попытки стать родителями до встречи со своей будущей суррогатной матерью, на SMO определяли, насколько пара «достойна» ребёнка. Беренд говорит: ирония заключается в том, что чем больше и лучше сурро были информированы о процессе и его рисках, тем чаще денежные интересы отходили для них на второй план, так как женщины понимали, что никакие компенсации несравнимы с рисками, которые они на себя принимают. Начав путешествие и пройдя через выкидыши, неудачные трансферы фетусов и проч., женщины хотели для себя и своей пары «счастливого конца» больше, чем денежной компенсации.

Беренд конституирует, что современные сурро коллективно примиряют деньги с альтруизмом, а не просто оправдываются перед критиками, как это было в начале 2000-х гг. По наблюдениям Беренд, сурро часто отмечали, что мы живём во времена, когда люди перестали понимать альтруизм, и сами видели его в том, что они готовы помочь кому-то чужому и получить компенсацию, а другие люди нет. Критики СМ действительно не разделяют подобный взгляд на альтруизм. Феминистские исследователи считают желание женщин помочь бездетным проявлением «ложного сознания», юристы видят в суррогатных матерях рациональных акторов, преследующих денежные интересы под прикрытием социально одобряемой риторики альтруизма и гендера. Сурро же активно переопределяют сам альтруизм, утверждая важность в нем реципрокности. Для них альтруизм предполагает ситуацию обоюдного выигрыша, в которой бездетная пара получает ребёнка, а сурро - компенсацию, тепло дружеских отношений и признание принесённой ею жертвы. Женщины различают свой «реальный», «разумный» альтруизм и «альтруистическую чепуху» (имеются в виду разговоры людей без опыта СМ о том, что настоящие альтруистки не должны просить компенсацию).

Некоторые участницы сравнивали СМ с искусством и хобби, противопоставляя его работе по найму. Первые нельзя полностью измерить деньгами, они предполагают безусловную вовлеченность и множество неуловимой (intangible) работы, неисчислимой рыночными способами. Женщины часто объясняли эту разницу, рассуждая о том, как много получали бы, применив к СМ логику почасовой оплаты, с которой они имеют дело в офисе. Сурро утверждали, что именно в силу того, что по рыночным меркам им не доплачивают за их усилия, вынашивание чужого ребёнка не является рыночной трансакцией. Риторика почасовой оплаты помогала суррогатным матерям подрывать и заменять логику рынка логикой дара: «<..> С моей компенсаџией <... я получаю 1,27 дол. в час < .. > Отдаю себя на 100\%, 24 часа в день, 7 дней в неделю на протяжении года, чтобы дать моим прекрасным IPs семью. Как не называть это даром???» (р. 161).

Сурро выработали определение компенсации: это то, что помогает женщине сохранять нормальное течение дел в своей семье, пока она помогает другой семье. Они терпеливо втолковывали такое определение потенциальным родителям и другим читателям форума, напоминая им, что сурро - не одинокие женщины, но жены и матери.

Компенсация - это один из терминов, в определении которого сурро достигли согласия, и они считали его приемлемым для обсуждения в рамках отношенческого пакета (relational package) своего 
поля. С годами женщины выработали общее понимание связанного термина «разумная компенсация» (reasonable compensation). Они настаивали на индивидуальном подходе к каждому случаю в определении разумности компенсации, что соответствует их представлением об уникальности каждых личных отношений, участников и путешествия. В то же время существовало согласованное понимание размеров средней компенсации, которое помогало женщинам балансировать в переговорах между «неэгоистичностью» и «низкой самооценкой». Однако ценность в мире СМ не определяется только деньгами. Признание, эмоции пары являются ценностью для суррогатных матерей и определяют отношения СМ как интимные. Как писал Джеральд Клори, эмоции, как деньги, являются маркером ценности [Clore 2005]. Определение СМ, таким образом, тоже производит моральные ценности, так как подтверждает большую важность сочувствия, сострадания, уважения, заботы и любви по сравнению с рыночной калькуляцией. Для сурро СМ - это нравственная история про женщин, помогающих другим женщинам, и про семьи, помогающие другим семьям.

Беренд подчёркивает, что суррогатные матери давали себе и друг другу обет не только выращивать жизнь, но и залечивать раны бесплодия в душах своей пары. Их понимание собственной миссии резко контрастировало со стигмой компенсируемого СМ, поэтому им приходилось дискурсивно примирять культурные оппозиции жизни и оплаты. Вместо профанации жизни деньгами сурро настойчиво подчёркивали сакральность мечты бездетной пары о ребёнке. Беренд утверждает, что, вопреки страхам критиков, в поле СМ произошла не коммодификация беременности и детей, а ритуализация «наивысшего дара» суррогатных матерей и повышение сакрализации жизни. И это, по мнению Беренд, превратило СМ во фронтир, который предлагает нам новое понимание отношенческой природы человеческих практик [Bandelj 2012; Zelizer 2012].

Работа Беренд демонстрирует, что компенсируемое СМ - это и моральное, и рыночное предприятие. Участники (чаще всего - посторонние друг другу люди) по собственной воле вступают в договорные отношения; однако вынашиваемые дети и роды - это не товары, а уникальные, неотчуждаемые и незаменяемые личности и события, которые, как верят сурро и некоторые родители, создают пожизненные связи между дарительницей и получателями. Одни видят эти связи как тревожащие, другие их с готовностью принимают. В отсутствие социальных прецедентов таких отношений стороны в каждом конкретном случае вырабатывают нравственные правила вовлеченности в договорную близость.

Беренд считает, что имплицитно подняла вопрос, заданный когда-то Маргарет Радин: зависит ли правильность и (или) неправильность любых трансакций, в которых деньги и родительские права передаются из рук в руки, от того, как мы о них думаем? (см., например: [Radin 1995]). Беренд говорит, что отвечает на него на своих данных не потому, что ей хочется ответить на нормативный вопрос о правильном и неправильном, а потому, что способы, которыми сурро коллективно осмысляют эти ситуации, дают им ответы о нравственной правильности суррогатного материнства. Беренд с помощью этнографического микроподхода показывает, как в своей культурной и организационной работе на SMO женщины в течение длительного времени дискурсивно примиряли деньги и дар, контракт и любовь, оформляя, согласовывая и наделяя эти сложные переплетения практическими и нравственными значениями.

Единственный для меня недостаток этой замечательной книги обусловлен спецификой выбранного Беренд метода анализа. Последовательно реализуя подход обоснованной теории и осторожно привлекая внешние концепты и теории, автор, на мой взгляд, не развила те направления анализа полевого материала, которые, скорее всего, показались бы особенно перспективными антропологу. Например, она не рассматривала речевое поведение на SMO как ритуальное. Формально сославшись на универсальность метафоры СМ как путешествия, отметив его трансформационную функцию, базовую трёхчастность (договор - беременность - роды) и особую важность выхода («закрытия двери»), Беренд 
так и не сделала ожидаемый антропологом шаг к анализу путешествия как ритуала, к интерпретации многоаспектного балансирования суррогатных матерей, одновременно являющихся и пассивными беременными объектами ритуала, и его экспертами-распорядителями. Недоиспользованными в анализе оказались и возможности других антропологических теорий (сакрального, дара, долга, обмена и проч.), не получила заслуженного развития вскользь затронутая автором тема онлайн-поста как драмы и др. В то же время во многом само появление ощущения неполноты анализа становится возможным из-за того, как Беренд впускает читателя в дискурсивный мир SMO. Она приводит множество больших и ярких цитат из постов, дискуссий и своей переписки с участницами, тщательно вписывая их в контексты, не только давая восхитительное ощущение погружения и вовлеченности, но и оставляя возможности для альтернативных читательских интерпретаций происходящего. Я рекомендовала бы читателю книгу Жужи Беренд по многим причинам, однако этот потенциал многократной пересборки материала кажется мне наиболее привлекательной её особенностью.

\section{Литература}

Bandelj N. 2012. Relational Work and Economic Sociology. Politics and Society. 40 (2): 175-201.

Clore G. L. 2005. For Love or Money: Some Emotional Foundations of Rationality. Chicago-Kent Law Review. 80 (3): 1151-1165.

Hadfield G. 1998. An Expressive Theory of Contract: From Feminist Dilemmas to a Reconceptualization of Rational Choice in Contract Law. University of Pennsylvania Law Review. 146 (5): 1235-1285.

Healy K. 2006. Last Best Gifts: Altruism and the Market for Blood and Organs. Chicago: University of Chicago Press.

Jacobson H. 2016. Labor of Love: Gestational Surrogacy and the Work of Making Babies. New Brunswick: Rutgers University Press.

Pande A. 2014. Wombs in Labor: Transnational Commercial Surrogacy in India. New York: Columbia University Press.

Roberts E. F. S. 1998. Examining Surrogacy Discourses: Between Feminine Power and Exploitation. In: Scheper-Hughes N., Sargent C. F. (eds). Small Wars: The Cultural Politics of Childhood. Berkeley and Los Angeles: University of California Press; 93-110.

Ragoné H. 1994. Surrogate Motherhood: Conception In The Heart. New York: Westview Press.

Sewell W. H. 1999. Concept(s) of Culture. In: Bonnell V. E., and L. Hunt (eds). Beyond the Cultural Turn: New Directions in the Study of Society and Culture. Berkeley: University of California Press; 35-61.

Teman E. 2010. Birthing a Mother: The Surrogate Body and the Pregnant Self. Berkeley: University of California Press.

Zelizer V. 2012. How I Became a Relational Economic Sociologist and What Does it Mean? Politics and Society. 40 (2): 145-174. 


\section{NEW BOOKS}

\section{Natalia Conroy \\ Rational Altruism: Is it Possible to Reconcile Morality with Markets?}

Book Review: Berend Z. (2016) The Online World of Surrogacy, NY, Oxford: Berghahn Books. 270 p.

\author{
CONROY, Natalia - Candidate \\ of Sciences in History, \\ Researcher, Laboratory for \\ Studies in Economic sociology \\ (LSES), National Research \\ University Higher School \\ of Economics. Address: 20 \\ Myasnitskaya str., Moscow, \\ 101000, Russian Federation.
}

\section{Email: nconroy@hse.ru}

\section{Abstract}

The book by Zsuzsa Berend is based on a decade-long ethnography of writing behavior of a "self-selected group of amazing women", www.surromomsonline.com users (the SMO'ers). This is not the first, but probably the longest study of American surrogacy and the social dynamics of online discussions, so I'm sure it will become a "must read" for researchers of different fields. The patterns of the discussions initiated by the SMO'ers were connected to parenting and motherhood, work and relationships, contract and money, goods and gifts, which were always the concepts of interest for both economic anthropology and economic sociology. Surrogate mothers and childless couples, who entered into their dialogue without mediators (or, to be precise, via the Internet), were trying to negotiate moral meanings of these concepts in the context of market rationality and to develop a win/win project aiming to bring a new life into the world. Berend who was analyzing their rhetorical efforts by using grounded theory package tried to answer a wider question "is it possible to reconcile morality with markets?" Although she brought some theoretical concepts (in particular, from the field of economic sociology) in her analysis, she also stayed very close to her informants' explanations of their reality. As a result and in my opinion, Berend found her answer to this question in the "native concept" of "real altruism" redefining the meaning of reciprocity and the balance of "given" and "received".

Keywords: assisted reproduction; surrogacy; relatedness; relational work; moralized markets; contract; money; gift; altruism.

\section{References}

Bandelj N. (2012) Relational Work and Economic Sociology. Politics and Society, vol. 40, no 2, pp. 175201.

Clore G. L. (2005) For Love or Money: Some Emotional Foundations of Rationality. Chicago-Kent Law Review, vol. 80, no 3, pp. 1151-1165.

Hadfield G. (1998) An Expressive Theory of Contract: From Feminist Dilemmas to a Reconceptualization of Rational Choice in Contract Law. University of Pennsylvania Law Review, vol. 146, no 5, pp. 12351285 .

Healy K. (2006) Last Best Gifts: Altruism and the Market for Blood and Organs, Chicago: University of Chicago Press. 
Jacobson H. (2016) Labor of Love: Gestational Surrogacy and the Work of Making Babies, New Brunswick: Rutgers University Press.

Pande A. (2014) Wombs in Labor: Transnational Commercial Surrogacy in India, New York: Columbia University Press.

Roberts E. F. S. (1998) Examining Surrogacy Discourses: Between Feminine Power and Exploitation. Small Wars: The Cultural Politics of Childhood (eds. N. Scheper-Hughes, C. F. Sargent), Berkeley and Los Angeles: University of California Press, pp. 93-110.

Ragoné H. (1994) Surrogate Motherhood: Conception In The Heart, New York: Westview Press.

Sewell W. H. (1999) Concept(s) of Culture. Beyond the Cultural Turn: New Directions in the Study of Society and Culture (eds. V. E. Bonnell, L. Hunt), Berkeley: University of California Press, pp. 35-61.

Teman E. (2010) Birthing a Mother: The Surrogate Body and the Pregnant Self, Berkeley: University of California Press.

Zelizer V. (2012) How I Became a Relational Economic Sociologist and What Does it Mean? Politics and Society, vol. 40, no 2, pp. 145-174.

Received: March 21, 2017.

Citation: Conroy N. (2017) Razumnyy al'truizm: mozhno li primirit' moral' i rynok? [Rational Altruism: Is it Possible to Reconcile Morality with Markets?]. Book Review on Berend Z. (2016) The Online World of Surrogacy. NY, Oxford: Berghahn Books, 270 p. Journal of Economic Sociology = Ekonomicheskaya sotsiologiya, vol. 18, no 2, pp.138-150. Available at https://ecsoc.hse. ru/2017-18-2.html (in Russian). 


\title{
КОНФЕРЕНЦИИ
}

\section{XVIII Международная научная конференция по проблемам развития экономики и общества}

\author{
11-14 апреля 2017 г.
}

XVIII международная научная конференция НИУ ВШЭ по проблемам развития экономики и общества состоится в Москве 11-14 апреля 2017 г. Её проводит Национальный исследовательский университет «Высшая школа экономики» при участии Всемирного банка. Председателем Программного комитета конференции является научный руководитель НИУ ВШЭ профессор Е. Г. Ясин.

\section{Программа секционных заседаний ${ }^{1}$}

Секция Db. Сетевой анализ

Руководитель: В. В. Кускова (НИУ ВШЭ)

11 апреля, вторник

12:00-13:30 Сессия Db-02. Наукометрические исследования российского социологическоАудитория 328, го поля

M-11

Председатель: Д. В. Мальцева (НИУ ВШЭ)

Е. С. Губа (ИПП)

Сетевая структура российских социологических журналов

Д. В. Мальцева (НИУ ВШЭ), С. П. Моисеев (НИУ ВШЭ)

Научное сообщество российских социологов: сетевой анализ биографических данных

И. А. Карпов (НИУ ВШЭ), Г. В. Градосельская (НИУ ВШЭ)

Типология связей в социальных сетях и выявление неявных связей пользователей

15:00-16:30

Сессия Db-03. Organizational Networks and Individual Attributes

Аудитория 328, Председатель: С. F. Fey (Aalto University School of Business)

M-11

C. F. Fey (Aalto University School of Business), R. Teigland (Stockholm School of

Economics), S. S. Wang (Zhejiang University), Y. Chen (Peking University)

Contingency Effects of National Culture and Institutions on How Social Networks Influence Individual Creativity

И. Б. Смирнов (НИУВШЭ)

Сегрегация школ в виртуальном пространстве

Y. Priestley (HSE), G. Beknazar-Yuzbashev (HSE)

Personality Traits Behind the Mutual Formation of Political Attitudes and Social Relationships

\footnotetext{
Здесь приводится информация о некоторых, наиболее интересных с точки зрения экономической социологии, секциях (предварительная версия от 13.03.2017). С полной версией программы конференции можно ознакомиться на сайте: URL: https://conf.hse.ru/2017/program/ - Примеч. ред.
} 
12 апреля, среда

12:00-13:30 Сессия Db-06. Business Networks

Аудитория 328, Председатель: E. Artyukhova (HSE)

M-11

F. López-Iturriaga (University of Valladolid), M. Zavertiaeva (HSE)

Networks of Directors on Russian Boards: The Hidden Part of the Corporate Governance Iceberg

E. Artyukhova (HSE), V. Kuskova (HSE)

Cross-Buying Customer Behavior and Sellers Efficiency in Internet Shopping in Russia

И. И. Кузнецов (НИУ ВШЭ)

Влияние внутриорганизационных коммуникационных сетей на успешность реализации проектов

\section{Секция G. Региональное развитие}

\section{Руководитель: Н. В. Зубаревич (МГУ)}

11 апреля, вторник

15:00-16:30 Сесся G-03. Доходы и потребление, социальная структура

Аудитория 522, Председатель: Н. В. Зубаревич (МГУ)

M-20

Н. Н. Михеева (ИНП РАН)

Потребительский спрос как фактор восстановления экономического роста: региональный аспект

М. Ю. Малкина (ННГУ)

Декомпозиция межрегионального неравенства в уровне среднедушевых доходов населения РФ по источникам доходов

D. Rudenko (Tyumen State University)

Income Inequality and Institutions in the Russian Regions

\section{Секция Ga. Города и агломерации}

\section{Руководитель: А. С. Пузанов (НИУ ВШЭ)}

11 апреля, вторник

12:00-13:30 Сессия Ga-02. Развитие городов в период постсоветской трансформации

Аудитория 230, A. Makhrova (MSU), A. Badyina (University of Birmingham), I. Brade (Leibniz Institute

M-20

for Regional Geography), O. Golubchikov (Cardiff University)

Синхронный Uneven Urban Resilience: The Economic Adjustment and Polarization of Russia's Citперевод ies

О. В. Сульдина (НПАО «ЭХО»), И. В. Баскакова (УрФУ)

Города-предприниматели: есть ли такие в современной России?

E. В. Антонов (Институт географии РАН)

Рынки труда городов Урала, Сибири и Дальнего Востока: постсоветская трансформация и современные модели адаптации населения

15:00-16:30 Сессия Ga-03. Пространственная структура современного города

Аудитория 230, Р. В. Гончаров (НИУ ВШЭ), К. С. Никогосян (НИУ ВШЭ)

M-20

Механизмы формирования центров активности в крупном городе (на примере

г. Москвы)

Е. А. Котов (НИУ ВШЭ), Р. В. Гончаров (НИУ ВШЭ)

Постиндустриальная городская полицентричность

Н. А. Костко (ТюмГИУ)

Социальное пространство города и исследование территориальной идентичности

горожан с помощью метода ментальных карт 
17:00-18:30 Сессия Ga-04. Социальное пространство и социальные общности в городе Аудитория 230, М. А. Шуклина (НИУ ВШЭ)

M-20 Влияние новых медиа на формирование образа места на примере района Бутово,

Синхронный г. Москва

перевод Л. Д. Скобелева (НИУ ВШЭ, Нижний Новгород), М. Ю. Плотникова

(НИУ ВШЭ - Нижний Новгород), А. А. Кудрина (НИУ ВШЭ, Нижний Новгород)

Хипстеры столицы и провинции: особенности легитимации социального феномена

А. В. Городничев (НИУ ВШЭ)

Пространственное неравенство в Москве: структура города и распределение благ в нём

M. Buedenbender (KU Leuven), D. Zupan (researcher)

How to Transform Moscow into a Just City?

\section{Секция Н. Экономическая история}

Руководитель: М. А. Давыдов (НИУ ВШЭ)

12 апреля, среда

10:00-11:30 Сессия Н-05. Методологические проблемы экономической истории

Аудитория 428, Председатель: С. А. Саломатина (МГУ)

M-11 A. Magliulo (UNINT)

Синхронный The Origins of Economic Nationalism in Europe

перевод $\quad$ А. Ю. Володин (МГУ)

Парадокс изобилия: как объединить теорию и историю на примере России

М. А. Давыдов (НИУ ВШЭ)

Сберегательные практики российской деревни в конце XIX — начале XX веков: к вопросу об уровне крестьянского благосостояния

12:00-13:30 Сессия Н-06. Экономическое развитие дореволюционной России

Аудитория 428, Председатель: Т. Я. Валетов (МГУ)

M-11

М. Н. Барышников (РГПУ им. А. И. Гериена)

Русское общество пароходства и торговли: эволюция договорных отношений со служащими. 1856-1876 гг.

С. А. Саломатина (МГУ)

Банк «для своих»: кредитные практики в Москве в 1890-е гг.

A. В. Мамаев (ИРИ РАН, ИЭ РАН)

Опыт решения продовольственной проблемы в городах в годы Первой мировой войны: роль местного самоуправления

15:00-16:30 Сессия Н-07. Экономическое развитие Советской России

Аудитория 428, Председатель: М. А. Давыдов (НИУ ВШЭ)

M-11

N. Nenovsky (University of Picardie Jules Verne)

The Soviets Monetary Experience (1917-1924) through the Perspective of the Discussion on Unity and Diversity of Money

Д. Е. Шестаков (Банк России)

Технический прогресс и советская индустриализация

С. Б. Ульянова (СПбПУ)

Советский индустриальный политический проект 1920-х — начала 1930-х гг::

основные этапы разработки

D. Ivanov (HSE), E. Borisova (HSE)

Loss of Human Capital and Development: Evidence from Russian Germans Repatriation 
17:00-18:30 Сессия Н-08. Социально-экономическое развитие России в $\mathbf{X X}$ - начале Аудитория 428, ХXI века

M-11

Председатель: С. Б. Ульянова (СПбПУ)

Т. Я. Валетов (МГУ), Х. Кесслер (Международный институт сочиальной истории)

Изменения профессиональной структуры населения России (СССР) за 1897 2002 гг.

В. Л. Некрасов (СурГПУ), Д. И. Филиппова (СурГПУ)

Бюрократические иерархии, академические сети и экономический реформизм в СССР (вторая половина 1950-х — первая половина 1960-х гг.)

Д. В. Маслов (МГОУ)

От советского человека к россиянину: смена исторических стереотипов

М. Г. Фивейская (РАНХиГС)

Феномен советского качества: городское жильё в нормативном и социальном измерении

\section{Секция L. Фирмы и рынки}

Руководители: Н. А. Волчкова (РЭШ - ЦЭФИР), Т. Г. Долгопятова (НИУ ВШЭ)

11 апреля, вторник

15:00-16:30 Сессия L-03. Почётный доклад В. В. Радаева (НИУ ВШЭ) «Как эволюциониАудитория 309, руют нелегальные рынки (на примере рынков нерегистрируемого алкоголя в M-20 России в 1980-2010-е годы)»

Синхронный перевод

Рынки, связанные с незаконным оборотом продукции, пока не стали объектом детальных исследований, несмотря на своё присутствие во всех без исключения экономиках. Дефицит категоризации этого сложного объекта дополняется отсутствием надёжных эмпирических данных. В работе исследуются структура и эволюция рынков нерегистрируемого алкоголя в России с периода позднего социализма с особым фокусом на рынках домашнего алкоголя, контрафактных алкогольных напитков и неучтённого алкоголя промышленного производства. На основе многообразных статистических и опросных данных демонстрируется, что комбинация гетерогенных нелегальных рынков проходит через четыре стадии своего развития. На каждой стадии отдельные рынки выходят на передний план, в то время как другие остаются в неразвитом состоянии или демонстрируют нисходящие тренды. В целом нелегальные рынки, как правило, растут в периоды экзогенных экономических шоков, в то время как в периоды относительной стабильности и экономического роста эти рынки сжимаются или, по крайней мере, остаются на прежнем уровне. Изменения в структуре нелегальных рынков подпитываются периодической переквалификацией продуктов, организаций и транзакций, постоянно двигая границы между легальным и нелегальным. Некоторые виды нелегальной деятельности сохраняют легитимность благодаря неосведомлённости или толерантности конечных потребителей продукции и регулирующих организаций. Границы между легитимным и нелегитимным оказываются ещё более размытыми, чем границы между легальным и нелегальным. 
17:00-18:30 Сессия L-04. Почётный доклад Г. Симона (Simon-Kucher \& Partners Strategy

Аудитория 429, \& Marketing Consultants) «Скрытые чемпионы - в авангарде глобалии»

M-11

Председатель: А. Ю. Юданов (Финуниверситет)

Синхронный

перевод

Рост мирового экспорта опережает рост внутреннего валового продукта стран. Глобалия, мир будущего в условиях глобализации, предлагает неограниченные возможности роста. Страны демонстрируют очень неравномерные показатели производительности. Среди крупных стран Германия далеко опережает всех по объёмам экспорта на душу населения. Это происходит не за счёт её крупных корпораций, но благодаря преобладающему влиянию средних, малоизвестных лидеров мирового рынка, так называемых скрытых чемпионов. В Германии их несравнимо больше, чем в других странах. Скрытые чемпионы: ставят перед собой чрезвычайно амбициозные цели, сосредоточивают усилия на узких рынках в сочетании с продажами и продвижением товаров на мировых рынках, очень тесно работают со своими клиентами и активно внедряют инновации, их лидерство ориентировано на долгосрочную перспективу, а работники получают значительную свободу действий, которая создаёт высокую мотивацию и снижает текучесть кадров.

Страны и компании всех типов могут извлечь много полезного из этих малоизвестных моделей.

13 апреля, четверг

12:00-13:30 Cессия L-10. Институты и предпринимательство

Аудитория 429, Председатель: В. В. Голикова (НИУ ВШЭ)

M-11

N. Chakravorty $(S F U)$

Синхронный Impact of the Corrupt Behavior of the Government Officials on Firm Growth in the перевод Manufacturing Industrial Sector of Bangladesh

В. И. Нефёдкин (ИЭОПП СО РАН)

Концентрация корпоративной власти в России: основные тенденции и последствия

М. И. Гладкая (НИУ ВШЭ, Санкт-Петербург)

Демократические институты и развитие предпринимательства: анализ данных по регионам России

Г. В. Шагбазян (НИУ ВШЭ, Нижний Новгород), А. В. Аистов (НИУ ВШЭ, Нижний Новгород)

Предпринимательство и институты

Дискуссант: Е. И. Борисова (НИУ ВШЭ)

Секция О. Качество государственного управления

Руководители: А. В. Клименко (НИУ ВШЭ), А. А. Яковлев (НИУ ВШЭ)

11 апреля, вторник

12:00-13:30 Сессия О-02. Коррупция, права собственности и теневая экономика: теоретиАудитория 125, ческие и эмпирические модели

M-20

Председатель: Л. И. Полищук (НИУ ВШЭ)

Синхронный

B. Ponomariov (University of Texas), O. Balabushko (World Bank), G. Kisunko (World

перевод

Bank)

Tax Administration Practices and Firms' Perceptions of Corruption: Evidence from Europe and Central Asia

Л. И. Полищук (НИУ ВШЭ), А. Рубин (НИУ ВШЭ), Р. Кочнев (НИУ ВШЭ)

Коррупция в режиме «одного окна»: последствия для регионального развития А. В. Костин (НГУ), А. Д. Кашникова (НГУ), А. В. Мартель (НГУ)

Теневая экономика: моделирование, равновесие и влияние на благосостояние 
13 апреля, четверг

17:00-18:30 Сессия 0-12/1. Почётный доклад Чарльза Сейбла (Школа права КолумбийАудитория 101, ского университета) «Промышленная политика в условиях неопределённоM-20 сти: основные принципы и их применение»

Синхронный перевод Председатель: А. А. Яковлев (НИУ ВШЭ)

Сталкиваясь с такими проявлениями неопределённости, как непредсказуемые изменения уровня и структуры спроса, а также направлений технологического развития, современные компании не стремятся защитить себя, а, напротив, по мере того как они становятся более уязвимыми в условиях потрясений, быстро учатся отвечать на кризисные изменения и использовать неожиданные возможности. На производстве этот переход принимает форму вертикальной дезинтеграции в результате отказа от подконтрольных поставщиков, поскольку их функции становятся избыточными или устаревают, а также путём устранения незавершённого производства. В результате нарушения производственного цикла предприятие останавливается, и операции можно возобновить только после того, как будет выявлена и устранена причина сбоя.

Аналогичный переход к производственным моделям, основанным на коротких и интенсивных циклах обучения, активно происходит в сельском хозяйстве, добывающей промышленности и в индустрии наукоёмких коммерческих услуг. По этой причине наращивание потенциала либо приобретение общих навыков, необходимых для экономического развития, возможно практически во всех отраслях современной экономики.

В таких условиях целью политики развития промышленного производства является стимулирование развития компаний, которые способны реагировать на неопределённость и, таким образом, в итоге воспользоваться новыми возможностями в глобальных цепочках поставок.

На основе информации, полученной компаниями в процессе внутреннего мониторинга, разработка подобных политик строится на использовании коротких циклов обучения для устранения проблем в процессе практической реализации либо при необходимости для корректировки цели. Мониторинг реализации проектов становится столь же важным, как и первоначальный выбор проектов, поскольку в условиях неопределённости успешные планы развития почти всегда подвергаются изменениям в процессе реализации.

Непрерывный мониторинг и корректировка планов, в свою очередь, приводят к продуманной децентрализации полномочий с передачей функции принятия решений лицам на самом нижнем уровне (поскольку чем ниже уровень принятия решений, тем выше вероятность, что эти лица располагают ключевыми фоновыми знаниями) на основе привлечения всех участников, обладающих необходимыми экспертным опытом.

Эти темы рассматриваются в докладе на примере применения производственных политик нового поколения в Малайзии и Перу. 


\section{Секция Р. Демография и рынки труда}

\section{Руководители: В. Е. Гимпельсон (НИУ ВШЭ), М. Б. Денисенко (НИУ ВШЭ)}

11 апреля, вторник

15:00-16:30 Сессия Р-03. Миграция и мигранты в России

Аудитория 513, Председатель: Н. В. Мкртчян (НИУ ВШЭ)

M-20

Е. Ю. Полякова (НИУ ВШЭ), Л. И. Смирных (НИУ ВШЭ)

Интеграция лиц с иностранным происхождением на российском рынке труда К. А. Доронина (ИНП РАН)

Трансформация миграционных тенденций в Москве на фоне мировых мегаполисов

Ю. Ф. Флоринская (РАНХиГС), Н. Мкртчян (НИУ ВШЭ)

Работодатели и трудовые мигранты: взаимодействие на фоне кризиса

А. Н. Резяпова (НИУ ВШЭ), Н. Г. Мещерякова (НИУ ВШЭ), С. В. Швыдун

(НИУ ВШЭ), Ф. Т. Алескеров (НИУ ВШЭ)

Анализ влияния стран в сети международной миграции

12 апреля, среда

12:00-13:30 Сессия Р-06. Рынок труда: жёсткость зарплаты и безработица

Аудитория 513, Председатель: С. Ю. Рощин (НИУ ВШЭ)

M-20

А. С. Анисимова (НИУ ВШЭ, Нижний Новгород), А. В. Ларин (НИУ ВШЭ, Нижний Новгород)

Жёсткость номинальной зарплаты или мобильность работников?

А. В. Шевчук (НИУ ВШЭ), Д. Стребков (НИУ ВШЭ)

Цена гибкости: как нестандартный график работы влияет на субъективное благополучие самозанятых работников (на примере фрилансеров)

Н. Д. Воронина (НИУ ВШЭ), Е. Г. Варданян (НИУ ВШЭ), Т. Я. Четвернина (НИУ ВШЭ)

Длительная безработица: что способствует большой продолжительности периода незанятости безработных граждан?

15:00-16:30 Сессия Р-07. Рынок труда: институты и предложение труда

Аудитория 513, Председатель: В. Е. Гимпельсон (НИУ ВШЭ)

M-20

B. Rao (IIT Roorkee)

Синхронный Impact of Rright to Work' on Compliance of Minimum Wages in Informal Labour Marперевод ket: Emprical Evidenecs from Delhi NCR

С. Д. Капелюк (СибУПК)

Гендерные роли и трудовые доходы в российских домохозяйствах

S. Amine (UQO)

The Evolution of Unskilled Workers in Canada

F. Pattanaik (IIT Roorkee), P. Singh (IIT Roorkee)

Economic Growth, Education, and Female Labour Force Participation: A Decomposition Analysis for Feminization U Hypothesis 


\section{7:00-18:30 Сессия Р-08. Рынок труда: региональное измерение}

Аудитория 513, Председатель: Р. И. Капелюшников (НИУ ВШЭ)

M-20

T. В. Блинова (ИАгП РАН), С. Г. Былина (ИАгП РАН), В. А. Русановский (ССЭИ)

Факторы и детерминанты межрегиональных различий молодёжной безработицы в России

А. Г. Коровкин (ИНП РАН), И. Н. Долгова (ИНП РАН), Е. А. Единак (ИНП РАН), И. Б. Королев (ИНП РАН)

Роль профессионального образования при согласовании спроса на рабочую силу и её предложения: национальный и региональный аспекты

М. А. Гильтман (ТюмГУ), А. А. Вотякова (ТюмГУ)

Институциональный анализ программ поддержки занятости населения в субъектах РФ в 1995-2016 гг.

Н. В. Дорохова (ВГУИТ), А. А. Федченко (ВГУ), Е. С. Дашкова (ВГУ)

Исследование неформальной занятости в регионе: комплексный подход

\section{Секция Т. Социокультурные процессы}

\section{Руководители: В. С. Магун (ИС РАН), Э. Д. Понарин (НИУ ВШЭ)}

12 апреля, среда

10:00-11:30 Сессия T-05. Экономическая культура

Аудитория 422, Председатель: А. В. Белянин (НИУ ВШЭ)

M-11

Г. А. Монусова (ИМЭМО РАН)

Отношение к перераспределению доходов и социальная мобильность: объективные и субъективные индикаторы

E. Borisova (HSE), A. Govorun (HSE), D. Ivanov (HSE)

Bridgingor Bonding? Preferences for Redistribution and Social Capital in Russia

M. Bryukhanov (HSE)

Does Higher Education Change Attitudes Towards Government Price Controls in Russia?

Н. Э. Соболева (НИУ ВШЭ)

Влияние трудовых ценностей на взаимосвязь между удовлетворённостью работой и удовлетворённостью жизнью в Европе

Дискуссант: Р. И. Капелюшников (ИМЭМО РАН, НИУ ВШЭ)

\section{Секция Та. Социальная политика}

\section{Руководители: Л. Н. Овчарова (НИУ ВШЭ), Т. Я. Четвернина (НИУ ВШЭ)}

12 апреля, среда

10:00-11:30

Аудитория 228,

M-20

\section{Сессия Та-05. Бедность и неравенство}

\section{Председатель: А. И. Пишняк (НИУ ВШЭ)}

Л. И. Ниворожкина (РГЭУ (РИНХ))

Взаимосвязь уровня экономического неравенства и скрытых доходов домохозяйств

D. Rudenko (ТюмГУ), A. Sätre (UppsalaUniversity)

Trends in Poverty, Inequality and Social Policy in Contemporary Russia

Е. Д. Слободенюк (НИУ ВШЭ)

Факторы абсолютной и субъективной бедности в современной России

В. С. Жаромский (ИСП)

Оценка согласованности ответов респондентов в отношении разных профилей

бедности: построение комплексной оценки бедности 
12:00-13:30 Сессия Та-06. Социальная стратификация

Аудитория 228, Председатель: Н. Е. Тихонова (НИУ ВШЭ)

M-20

Е. М. Авраамова (РАНХиГС)

Новые вызовы расширению российского среднего класса

А. И. Пишняк (ЦАДУЖ)

Динамика среднего класса в России: от 2000-го к 2015-му

С. В. Мареева (НИУ ВШЭ), Н. Е. Тихонова (НИУ ВШЭ)

Доходная стратификация российского общества

В. А. Аникин (НИУ ВШЭ)

Доходная стратификация по медиане: опыт социолого-статистической валидизации групп

А. Я. Бурдяк (ИНСАП РАНХиГС), А. О. Макаренщева (ИНСАП РАНХиГС),

T. М. Малева (ИНСАП РАНХиГС)

Социальная мобильность поколений и средние классы в России: эмпирический анализ

Секция Ть. Социология

Руководитель: Е. Ю. Рождественская (НИУ ВШЭ)

12 апреля, среда

12:00-13:30 Сесся Tb-06. Социальные аспекты потребления и рынки услуг

Аудитория 421, Председатель: 3. В. Котельникова (НИУ ВШЭ)

M-11 RUS $\quad$ Р. И. Романова (НИУ ВШЭ), Е. С. Бердымева (НИУ ВШЭ)

Реакции российских потребителей на изменение цен в условиях финансового кризиса: к формированию социальной устойчивости

А. П. Казун (НИУ ВШЭ)

«Адвокат дьявола» для «оборотня в погонах»: какие адвокаты защищают российских правоохранителей, попавших под суд?

T. Ю. Богомолова (ИЭОПП СО РАН), А. В. Диева (ИЭОПП СО РАН), Т. Ю. Черкашина (ИЭОПП СО РАН)

Нефинансовое богатство российских домохозяйств: что, сколько и у кого в соб-

ственности

Ю. Лежнина (НИУ ВШЭ)

Доходная стратификация российского общества и дифференцированность стандартов потребления

15:00-16:30 Сессия Tb-07. Социальные проблемы труда - 1

Аудитория 421, Председатель: Р. Н. Абрамов (НИУ ВШЭ)

M-11

T. Ю. Сидорина (НИУ ВШЭ)

Новый мир - новые трудовые практики - новые акторы на рынке труда. Предложения, риски и социальные эксперименты

Н. Э. Соболева (НИУ ВШЭ)

Трудовые ценности и предпочтения относительно работы в Европе: гендерный аспект

А. В. Каравай (РАНХиГС)

Человеческий капитал российских рабочих: состояние и факторы 


\section{7:00 -18:30 Cессия Tb-08. Социальные проблемы труда - 2}

Аудитория 421, Председатель: Р. Н. Абрамов (НИУ ВШЭ)

M-11

И. Л. Сизова (НИУ ВШЭ)

Прекаризация и прекариат в постиндустриальных экономике и обществе Д. К. Ходоренко (НИУ ВШЭ - Санкт-Петербург), В. В. Титкова (НИУ ВШЭСанкт-Петербург)

Стратификация профессий в многомерном пространстве Блау

Н. Н. Жидкевич (НИУ ВШЭ)

Отходники в местном сообществе: восприятие другими и самоощущение

T. А. Лапина (ОмГУ), С. Н. Апенько (ОмГУ)

Нестандартная занятость: прекаризация или гуманизация труда?

14 апреля, пятница

10:00-11:30 Сесся Tb-13. Социальная, территориальная и жилищная мобильность

Аудитория 421, Председатель: А. В. Стрельникова (НИУ ВШЭ)

M-11

А. В. Ваньке (ИС РАН)

Проективные методики в исследовании социальных траекторий и мобильности (на примере рисунков линии жизни)

Е. В. Полухина (НИУ ВШЭ)

Значение жилья в оптике социальной мобильности: анализ двух поколений А. В. Стрельникова (НИУ ВШЭ)

Переезды и жизненный успех: пространственный аспект социальной мобильности П. Е. Сушко (ИС РАН), Н. Д. Коленникова (НИУ ВШЭ)

Типология миграционных биографий россиян (по материалам эмпирических исследований) 
CONFERENCES

\section{April International Academic Conference on Economic and Social Development}

\section{1-14 April 2017 r.}

On April 11-14, 2017, National Research University Higher School of Economics (HSE), with the support of the World Bank, will be holding the XVIII April International Academic Conference on Economic and Social Development in Moscow. The Conference Programme Committee is chaired by Professor Evgeny Yasin.

Received: March 13, 2017.

Citation: XVIII Mezhdunarodnaya nauchnaya konferentsiya po problemam razvitiya ekonomiki i obshchestva NIU VShE (Moskva), 11-14 aprelya 2017 g. [XVIII April International Academic Conference on Economic and Social Development, 11-14 April 2017, NRU HSE, Moscow]. Journal of Economic Sociology = Ekonomicheskaya sotsiologiya, vol. 18, no 1, pp.151-161 . Available at: https://ecsoc.hse.ru/2017-18-1.html (in Russian). 


\section{INTERVIEWS}

\section{Interview with Peter Schweitzer: "If You No Longer Allow for the Possibility of Alterity, You are Limiting Your Options of Analyzing the World(s)"}

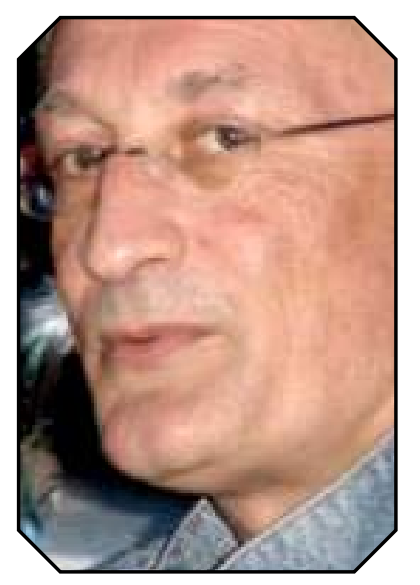

SCHWEITZER, Peter Professor, Department of Social and Cultural Anthropology, University of Vienna. Address: 7 Universitätsstrasse, 1010 Vienna, Austria.

Email: peter.schweitzer@ univie.ac.at
Peter Schweitzer is a Professor in the Department of Social and Cultural Anthropology at the University of Vienna. He was interviewed by Elena Gudova, a Ph.D. student and lecturer at the Higher School of Economics in Vienna in December 2016.

\begin{abstract}
In this interview, Peter Schweitzer discusses his interest in Siberian studies and Arctic research and addresses the so-called "ontological turn" within recent anthropological debates. His earlier academic interests in the hunting and gathering societies of Chukotka and northeastern Siberia took him to the University of Alaska Fairbanks and led to his eventual cooperation with natural science scholars examining climate change in the Arctic region especially in Alaska. Schweitzer's current research project, "Configurations of Remoteness," analyzes the construction of the Baykal-Amur Mainline [BAM] as an example of the influence of (transportation) infrastructure on the ecological and social conditions of a region. The research focuses on the mobility and sociality of people living in areas affected by the BAM and questions the construction of remoteness by observing shifts in that mobility and sociality among builders of the BAM. Schweitzer also discusses the current anthropological interest in ontology and suggests that, along with the more-than-human perspective in some of the social sciences, this enables scholars to go beyond the deconstruction of the "other" to allow for "alterity" as a tool in analyzing the world or worlds. The notion of different worlds (and one culture) is more radical than conceiving of one world from different cultural perspectives. A broader approach to human-environment relations that incorporates alterity offers more fruitful tools for researchers, expanding their analytical possibilities.
\end{abstract}

Keywords: alterity; more-than-human perspective in anthropology; ontological turn; Siberian studies; actor-network theory; Baykal-Amur Mainline.

\section{— Could you please tell us about your research background?}

- I am currently a Professor in the Department of Social and Cultural Anthropology at the University of Vienna. I am also a Professor Emeritus at the University of Alaska Fairbanks, where I worked for 22 years between 1991 (when I started as an assistant professor) and 2003, which is when I retired from there. Now, I'm a Professor Emeritus, which means that I'm still connected to this Alaskan uni- 
versity, but I am certainly more "Viennese" than "Alaskan" right now. I was born in Upper Austria and moved to Vienna after high school. After studying philosophy and political science, I was eventually educated at the same department in which I am now working again (leaving for Alaska a year after my Ph.D. graduation), so I am a kind of a returning migrant.

Initially, I was interested in the Near and Middle East; as a student, my anthropological interests focused on Turkey and Kurdistan. But then, at some point more than 30 years ago, it occurred to me that I knew Russian, which I had learned at high school. In 1985, I decided to focus on Siberia, both because I wanted to do something that would allow me to use my Russian language skills, and because I felt at the time that Siberia was completely neglected in Western scholarship. Many Soviet scholars were conducting research there, but Western anthropologists seemed less interested. At the time, I was interested in hunting and gathering societies, and I noted the absence of Siberian societies from these discussions. Some limited ethnographic information about Siberia was available in the English language, but none of it related to indigenous Siberian societies as hunting and gathering societies. Typically, western surveys of the status of hunting and gathering societies worldwide amounted to a short paragraph stating that Siberia had not been considered because there was too little available information. So, for me, while this interest in Siberia emanated from my linguistic skills, I also saw a need for it in Western scholarship because Siberia was a kind of blind spot. As a result, I spent the 1986-1987 academic year in Leningrad.

Of course, at that time being interested in Siberia as a Western scholar primarily meant sitting in libraries and archives, which was also my hosts' plan in Leningrad. Shortly after my arrival, however, I asked if I might visit Chukotka - more specifically, the Chukchi Peninsula. My local supervisor looked at me and said "No!" It was 1986, and access to remote areas of the country was highly regulated.

\section{— But things were changing.}

- Yes, although at that time, you had no way of knowing that the country was changing. During the academic year that I spent there, progress became visible to some degree. For example, a real high-water mark was Andrey Sakharov's release from exile at the end of 1986, when things really started to change. Everyday life in Leningrad in 1986 was still very "Soviet" - that is, there were very few public places that Soviet citizens and foreigners would frequent together. The signs of change were interpreted in different ways by the people around me, but no one could foresee that the dissolution of the Soviet Union was only five years away.

\section{— Why, at the beginning, did you decide to go there?}

- I wanted to learn about Siberia. Of course, I could have gone to libraries in Austria or Western Europe, but I decided that it would be best to go to Leningrad, the center of Siberian studies. While Austrian libraries had some books and articles about the anthropology of Siberia, libraries in Leningrad and Moscow had everything (or at least, all relevant Russian language materials). In addition, it was very important for me to bring my language skills to a higher level. I had first learned Russian at high school, and I took a few university courses in the mid-1980s, but I read very slowly at that point and couldn't really speak or converse freely. So, for me, that year made an enormous difference. In retrospect, it seems rather strange that I went there to understand Siberian societies but was instead offered a glimpse into Soviet and Russian society. Apart from reading books about Siberia, what I actually did there was a kind of year-long participant observation of an urban Soviet society. Even now, I still find it very interesting to try to understand Soviet and post-Soviet society. But officially, my task was always to understand something of the Chukchi and neighboring people.

\section{- Have you managed to go back since the Soviet collapse?}


- Yes, many times. After my return to Austria in 1987, I revisited the Soviet Union and Russia quite often. I was still working on my dissertation, so there were always reasons to go back. Up to 1991, when I moved to Alaska, I was there very often.

In 1990, I was finally able to go to Chukotka for fieldwork for the very first time. I had just defended my Ph.D., which was based on historical documents. In 1991, I took a position at the University of Alaska Fairbanks because they were suddenly looking for an expert on Siberia. Ten years before that, nobody (in the USA) had any experience of Siberia, and nobody needed it. Until 1991, it had been a total anthropological blind spot, but after the collapse of the Soviet Union, fieldwork became possible there.

When I moved to Alaska, my first major piece of research was an oral history project with a colleague from St. Petersburg, called "Traveling between Continents." For this work, it was no longer necessary to depend on records from the seventeenth or eighteenth centuries. Instead, to reconstruct the end of the nineteenth and twentieth centuries, we talked with people about what their parents and grandparents had told them in order to understand dimensions of indigenous history across the Bering Strait through oral history and personal narratives.

Then, about 15 years ago (in the early 2000s), a shift occurred. More and more natural scientists started coming up to me and saying "You are a social scientist, aren't you? We have so much work to do on climate change, and we need a social scientist's perspective on that." And I was among the first in Alaska to accept.

\section{- So, following your topics of interest, first it was Siberia, then the Arctic, and then it was climate change?}

- Part of Siberia is in the Arctic, but when I started to research Siberia, I had no notion of the "Arctic"-I approached it from the perspective of Russian studies. At a theoretical level, it was neither Arctic nor Northern but Siberian studies. For Russian readers, I should note here that I use "Siberia" in a Western sense, covering everything east of the Ural Mountains, including the Russian Far East.

In the 1990s, while I was in Fairbanks, Alaska, Arctic social science studies was only beginning to emerge, although Arctic (natural) science already existed as a field of study based on similar biophysical conditions. I soon became involved in the International Arctic Social Sciences Association (IASSA), which was newly founded in Fairbanks, Alaska. As its president from 2001 to 2004, I hosted one of its big conferences. We were trying to understand the similarities and differences between Arctic peoples, whether they lived in Chukotka or Alaska, or elsewhere.

Eventually, I became focused on what I would call the natural science-human science interface. I was involved primarily in a big interdisciplinary program called the "Experimental Program to Stimulate Competitive Research (EPSCoR)." Given the magnitude of the project (by the end, we were running a US\$20 million program), I became a kind of research manager — in other words, there was no time to do research myself.

\section{—... and then you returned to Austria?}

- Yes, and I knew immediately that I wanted to start a new project on Siberia. The proposal was developed in collaboration with Olga Povoroznyuk ${ }^{1}$ (who had worked in the BAM region before), Gertrude Saxinger, ${ }^{2}$ Sig-

\footnotetext{
Available at: http://core.univie.ac.at/team/olga-povoroznyuk/

2 Available at: http:/core.univie.ac.at/team/gertrude-saxinger/
} 
rid Schiesser, ${ }^{3}$ and Christoph Fink. ${ }^{4}$ The project received substantial support from the Austrian Science Fund (FWF), but it covered only a few selected case studies, conducted by the key team members in collaboration with local partners.

\section{— Could you please describe the project in a little more detail?}

— Its short title is "CoRe," which stands for "Configurations of Remoteness." In it, we explore the social agency of transportation infrastructure. As those working on the project are either anthropologists or geographers, it adopts a human-centered perspective. However, we also use heuristic tools to think beyond humans, such as ANT (actor-network theory) or Tim Ingold's ideas about meshworks and non-human actors [Ingold $2000 ; 2011]$. We also incorporate the notion of "remoteness" as a theoretical argument to justify our regional focus on Siberia.

\section{—What is that argument?}

- The argument is that the effective power of (new) transportation infrastructure can be better detected under conditions of remoteness - that is, where there is relatively little transportation infrastructure. So, we assume that if you build something big (like the BAM) in such an environment, it changes everything. And we are talking about relatively new infrastructure; construction started in 1974, and it took until 2003 to open the last tunnel. So, you can still talk with people who were part of building the railroad. And it's an ongoing process, which is what further interests us.

Eventually, I became interested in human-environment relations, leading to engagements with built environments and infrastructure. If you construct a train track, you might not pay a lot of attention to it, but this train track regulates certain things such as how people move, and how animals cross from one side to the other. In other words, you create a lot of unintended consequences.

\section{- By that do you mean social or natural unintended consequences, or do you distinguish between them?}

- I think it's not that important to distinguish between them. A range of consequences for human behavior also apply to non-human agents — animals, plants, and so on.

Historical research about the BAM is quite developed, but there have also been some sociological and anthropological projects. For example, sociologists from the St. Petersburg "Tsentr nezavisimykh sotsiologicheskikh issledovaniy" 5 conducted interviews with BAM builders — not in the BAM region but with those who had left and moved back to central regions such as St. Petersburg and Moscow. Likewise, we are interested in talking with people who are alive today, but we like to discuss history as much the present and future.

If you are dealing with a railroad, mobility is an obvious dimension of interest. Our approach to mobility is a mix of classical ethnographic qualitative methods, such as spending time in a place and talking with people. But in addition, we also used a quantitative tool. We developed a mobility questionnaire, which we tested in the field this summer, and now we're in the process of analyzing those data. Of course, for strictly statistical

3 Available at: http://core.univie.ac.at/team/sigrid-schiesser/

4 Available at: http://core.univie.ac.at/team/christoph-fink/

5 Centre for Independent Social Research. Available at: https://cisr.ru/en/

6 BAM-builders about BAM: The Past and Present of the Last Socialist Construction. Available at: https://cisr.ru/en/projects/ bamovtsy-o-bame-proshloe-i-nastoyaschee-posledney-stroyki-sotsializma/ 
purposes, you would need a larger pool of respondents, but we still think we can learn a number of things from these questionnaires.

We're interested in people who dealt with the BAM historically or do so today, but we're also curious about people who have nothing to do with the BAM, or with indigenous people who live at a distance from it.

\section{— Because they are still influenced by it?}

- Exactly. The whole idea is to understand how far the influence of the BAM extends for different groups of people living in the area. One of our team members was in a small village last year that is located a little over $150 \mathrm{~km}$ from the BAM. But there is no train connection to that village, nor is there a road linking to the outside world; you need a helicopter to get there. Not surprisingly, people there do not see themselves as connected to the BAM because, in terms of mobility, there are other elements that are much more important to them.

\section{- For sociality, would you just look at the relations between people living there, or maybe also between people and objects, people and organizations, people and the state?}

- That is one of the big questions we left incomplete in the funding application [laughs]. I think it would probably be easiest to do it in terms of human-to-human relations. As to the questionnaire, those were our constraints to make it practical. But conceptually, we understand that if you talk about infrastructure and about the built environment, one of the fascinating aspects is its materiality. I find it's also a fascinating topic in that it helps to overcome certain limitations of pure social constructivism. Of course, it's because we're humans - masters of constructing our world and our illusions - that we really construct a lot of the world we inhabit through our minds or the interaction of minds. But there is also climate change, which for me is another dimension, or the materiality.

- As you've touched on the subject of materiality, do you think there is a boundary between nature and actual sociality, or are they so deeply interconnected that we can't hope to define where one ends and the other begins?

- I think we normally draw rather clear lines in sociology and anthropology, and in the social sciences in general. But I think some of these more recent approaches in the social sciences, including ontological approaches, are trying to challenge that. Some scholars do it by going to the forests of Amazonia [Kohn 2013; Viveiros de Castro 1998; 2015] in an attempt to understand people who think differently about the relations between nature and culture, and between society and nature. I think that even without going there, even in our own society, the problems with these distinctions are obvious. I think we can develop perspectives in the social sciences that enable us to see relations with objects and with other-than-human beings differently.

— Can we somehow relate this to the ideas of Karl Polanyi, who distinguishes between substantive and formal economics...

- I think part of the attraction of Polanyi was that he talked about non-capitalist forms of economic relations, and about the social embeddedness of economic relations. I also think you could take it further and say that his views are about human embeddedness.

\section{— In nature?}

- No, not necessarily, but economic relations are embedded not only in social relations but in wider configurations - human and non-human or more-than-human relations - as well. Even in our capitalist society, in 
which - according to Polanyi-economic relations are dominant, we cannot free ourselves from dependence on "nature". Today, environmental degradation, climate change, peak oil, and many other things are constant reminders that the "natural environment" is not an externality but the very foundation of human economies.

\section{— Did construction of the BAM have any unintended consequences for social relations or economic relations?}

- The BAM started out as an idea, a plan, that changed several times before the construction of the "third BAM" commenced in the 1970s. By the time the BAM was completed and trains started to run, the world was very different from the one in which the plans had been drafted. The Soviet Union was in the process of disintegrating, meaning that the economic rationale for this project had almost disappeared. Shortly after the BAM was completed, there were a number of years in the 1990s, when there was hardly any use for it and there were even discussions of closing it down. But there are all these human communities that had been developed in order to build the BAM. Some of these settlements disappeared as planned, while others - which were supposed to be temporary ones - continued to exist. On every level, there were unintended consequences, because if you build something big, like a $1000 \mathrm{~km}$-long railway in an area where there had been nothing before, there are obviously enormous impacts in terms of industrial development, ecological relations, mobility, etc. Some of them are unexpected, such as when we met people in Tynda - a railroad hub that connects the BAM to the AYaM [the Amur-Yakutsk Mainline] and toward the TransSib in the South-for whom driving their own car was much more remarkable than using one of several train options.

\section{— That's really interesting. And what were the initial aims of the construction? These were economic aims, right?}

- Clearly, it was primarily about getting the untapped natural (mostly non-renewable) resources out of Eastern Siberia. And they're still uncapped because of the low global market prices. So, it's a mixture of tough economic times, low global market prices, and the limited capacity of the railroad because it only has one track, and there are only few passenger trains going there. A lot of natural resources (particularly, gold, coal and forest) are being shipped from Yakutia to East Asian markets. That uses up part of the tracks, and there are lots of other minerals that could also be exploited, but are too expensive right now. So, it's clear that this is and has always been about getting access to these mineral resources.

\section{- As you mentioned, you have talked with many people in the BAM region, so here comes the question of ontology. Is it one world and many perspectives, or are there many worlds?}

- I was raised and educated in one world, and within a scholarly perspective positing one world with many perspectives. But that doesn't mean that the ontological approach isn't interesting. For some people, like Eduardo Kohn, the more-than-human perspective is the central element within the so-called "ontological turn" [Kohn 2013]. I think these two things are not necessarily tied to each other; you can have more-than-human perspectives looking at one world. That's probably the one thing that is most important for me in this CoRe project, that it is about the more-than-human perspective: things and other kinds of non-human entities and beings can change how we, as people, behave, and how we, as people, think. Even if they are not conscious actors, they can be seen as actants in one way or another.

\section{— By actants, do you mean infrastructural objects, or are you referring to nature or animals?}

- Yes to all of the above. Anything can be an actant, at least in the actor-network theory (ANT) sense [see, e.g., Latour 1996]; ideas are also very often actants. When there is a big pile of rock in front of you and you are building a railroad, it forces you to do something. It has a strong impact, and you need to build around it 
or through it or over it. Of course, that is spoken from the Western ontological perspective. For example, in Iceland you have this concept that there are beings in the landscape, "hidden people" or elves, so when they build roads and houses, you need to make sure that these beings are not disturbed.

\section{- And how could we apply this approach to understanding economic relations or markets-labor or product markets, for example?}

- Supposedly, markets follow so-called market laws based on rational human behavior, but we all know that this is only part of the story. Obviously, supply and demand are important, but they are not the only things that determine human behavior in the market. Once you have acknowledged that - that there is more than supply and demand - then you have an open door for perspectives that acknowledge that human behavior are not limited to human ones.

\section{— But that might relate to culture and institutions. Is there anything beyond them?}

- ...if you want to use "culture" here, then human-environmental relations need to be part of it. Culture may be human-centered, but it is not limited to humans. Whether you go to a forest or whether you take a walk at a city park on a Sunday morning, these are cultural activities that involve a host of environmental relations. Economic or market behavior is not just determined by cultural aspects but by a number of non-human dimensions as well. Experience is important. When you live in the vast expanses of remote Siberia or in the American Midwest, you might develop a particular kind of relating to the environment you inhabit. Without advocating any kind of environmental determinism, it is obvious that a place like Tokyo provides different affordances to human and non-human actants alike. I think it is critical to acknowledge how the experience of and the materiality of the world you are living in contribute to shaping your behavior.

— Then I have one last question for you. The ontology debate is a really hot topic, and, in some sense, it seems a nice framework that one can apply, just to broaden one's ideas. But how would an anthropologist or a sociologist do that? What tools could they use?

- I am probably not the best person to talk to about this because I don't think that an ontological approach is the solution, nor do I think I have a particular way of applying it. I put this whole debate at the center of our seminar $^{7}$ more because of my own curiosity; what I'm really applying is the more-than-human perspective. You can take certain assumptions from the ontological approach and try to apply them to your case studies, wherever it is located, and it will fit some projects better than others. I think the most important thing is that you are open to the possibility of alterity. That has been a topic for the last 20 or 30 years, deconstructing being the other. But if you deconstruct otherness, then it is easy to take the opposite tack, denying anyone the possibility of radical alterity, when you construct someone like you. It's a form of ethnocentrism if you think "Okay, we are all living in the same world, and we all think the same way." Recent decades have demonstrated that certain constructions of otherness are nothing more than fantasies of the West about the other. The deconstruction of the other is important, but in that sense, an "ontological turn" is a necessary corrective to avoid going too far in that direction. If you no longer allow for the possibility of alterity then you are also limiting your options of analyzing the world, or worlds. I am not necessarily a big defender of the ontological approach, but I find it interesting - and, at times, polarizing. There are many schools of thought, and I have no intention of claiming that this one will be our salvation. But it is also premature to dismiss it as nonsense. As new perspectives emerge in the social sciences, they expand our ability to understand what is happening around us.

December, 2016 Vienna, Austria

7 "The Uses and Abuses of the Concept of Ontology" — seminar for University of Vienna PhD students. 


\section{References}

Ingold T. (2000) The Perception of the Environment: Essays on Livelihood, Dwelling and Skill, London: Routledge.

Ingold T. (2011) Being Alive: Essays on Movement, Knowledge and Description, London: Routledge.

Kohn E. (2013) How Forests Think: Toward an Anthropology beyond the Human, Berkeley: University of California Press.

Latour B. (1996) On Actor-Network Theory. A Few Clarifications Plus More Than a Few Complications. Soziale Welt, vol. 47, pp 369-381.

Viveiros de Castro E. (1998) Cosmological Deixis and Amerindian Perspectivism. Journal of the Royal Anthropological Institute, vol. 4, no 3, pp. 469-488.

Viveiros de Castro E. (2015) Who is Afraid of the Ontological Wolf? Some Comments on an Ongoing Anthropological Debate. The Cambridge Journal of Anthropology, vol. 33, no 1, pp. 2-17.

Received: January 20, 2017.

Citation: Interview with Peter Schweitzer: "If You No Longer Allow for the Possibility of Alterity, You are Limiting Your Options of Analyzing the World(s)". Journal of Economic Sociology = Ekonomicheskaya sotsiologiya, vol. 18, no 1, pp.162-169 . Available at: https://ecsoc.hse.ru/2017-18-1.html (in English). 
Экономическая

социология

T. 18. № 2.

Март 2017

Электронный журнал www.ecsoc.msses.ru

www.ecsoc.hse.ru

ISSN 1726-3247

\section{Адрес редакции}

101000, Россия,

г. Москва,

ул. Мясницкая,

д. 20, комн. 406

тел.: (495) 628-48-86

email: ecsoc@hse.ru

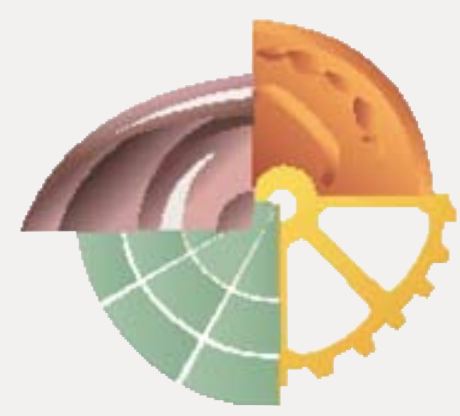

Journal of

Economic Sociology

Vol. 18. No 2.

March 2017

Electronic journal

www.ecsoc.msses.ru

www.ecsoc.hse.ru

ISSN 1726-3247

\section{Contacts}

20 Myasnitskaya street, room 406

101000 Moscow,

Russian Federation phone: +7 (495) 628-48-86

email: ecsoc@hse.ru

\section{Доступ к журналу}

- Доступ ко всем номерам журнала - постоянный, свободный и бесплатный.

- Каждый номер содержится в едином файле (10-12 п. л. в PDF).

- Если хотите, чтобы Вас оповещали о выходе очередного номера, пожалуйста, заполните форму подписки: https:/www.hse.ru/expresspolls/ poll/23725626.html

\section{Open Access Policy}

- All issues of the Journal of Economic Sociology are always open and free access.

- Each entire issue is downloadable as a single PDF file.

- If you wish to receive notification when new issues are published, please fill out the following form: https://www.hse.ru/expresspolls/poll/23725626.html 